Prepared in cooperation with the U.S. Navy

\title{
Kelp Forest Monitoring at Naval Base Ventura County, San Nicolas Island, California: Fall 2018 and Spring 2019, Fifth Annual Report
}

Open-File Report 2020-1091 
Cover Photo: Giant kelp forest at Nav Fac 100 supersite, San Nicolas Island, California, April 2, 2017. Photograph courtesy of Zach Randell, Oregon State University, used with permission. 


\section{Kelp Forest Monitoring at Naval Base Ventura County, San Nicolas Island, California: Fall 2018 and Spring 2019, Fifth Annual Report}

By Michael C. Kenner and Joseph A. Tomoleoni

Prepared in cooperation with the U.S. Navy

Open-File Report 2020-1091 


\title{
U.S. Department of the Interior \\ DAVID BERNHARDT, Secretary
}

\author{
U.S. Geological Survey \\ James F. Reilly II, Director
}

U.S. Geological Survey, Reston, Virginia: 2020

For more information on the USGS - the Federal source for science about the Earth, its natural and living resources, natural hazards, and the environment—visit https://www.usgs.gov or call 1-888-ASK-USGS.

For an overview of USGS information products, including maps, imagery, and publications, visit https://store.usgs.gov/.

Any use of trade, firm, or product names is for descriptive purposes only and does not imply endorsement by the U.S. Government.

Although this information product, for the most part, is in the public domain, it also may contain copyrighted materials as noted in the text. Permission to reproduce copyrighted items must be secured from the copyright owner.

Suggested citation:

Kenner, M.C., and Tomoleoni, J.A., 2020, Kelp forest monitoring at Naval Base Ventura County, San Nicolas Island, California: Fall 2018 and Spring 2019, fifth annual report: U.S. Geological Survey Open-File Report 2020-1091, 93 p., https://doi.org/10.3133/ofr20201091.

ISSN 2331-1258 (online) 


\section{Acknowledgments}

We would like to thank the U.S. Navy for funding and facilitating this research project. We also would like to thank our fellow divers: Jim Bodkin, Ken Collins, Michael Langhans, Keith Miles, Shannon Myers, Zach Randell, Kristen Sanchez, and Amy Story for hard work and good spirits. Thank you also to the captain and crew of the Magician for keeping us safe and comfortable.

Finally, thank you to reviewers Jessica Bredvik, George Esslinger, William Hoyer, and

Steve Lonhart, for their improvements to the manuscript. 



\section{Contents}

Acknowledgments ….......................................................................................................................

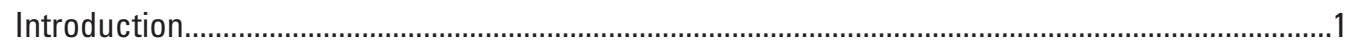

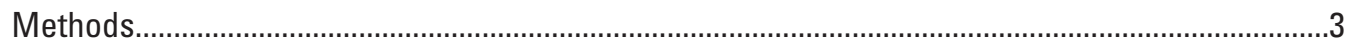

Site Design and Sampling Protocols ..................................................................................

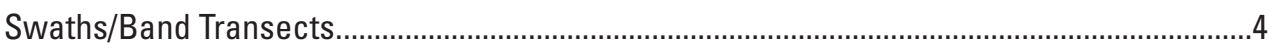

Random Point Contact (RPC) Sampling ..........................................................................

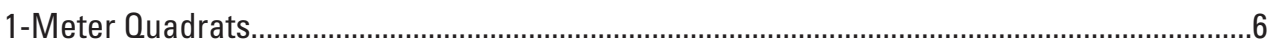

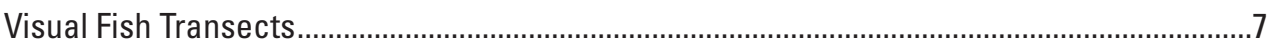

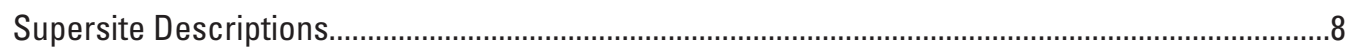

Nav Fac 100

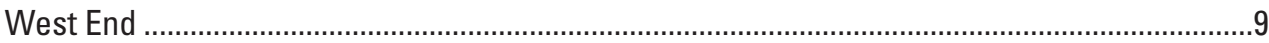

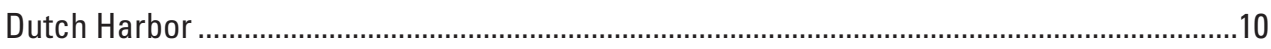

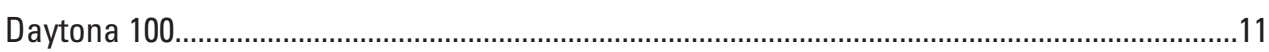

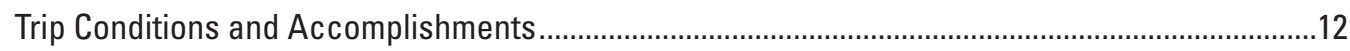

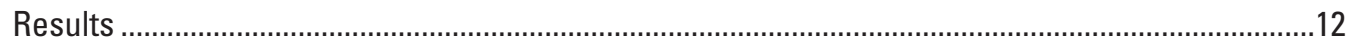

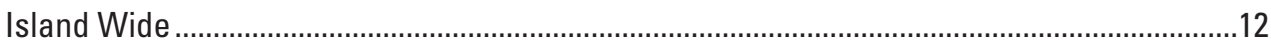

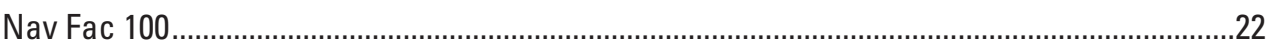

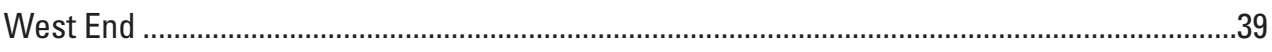

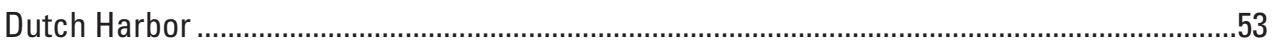

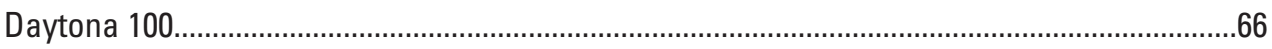

Long-term Patterns.................................................................................................. 80

Conclusions and Management Considerations.......................................................................91

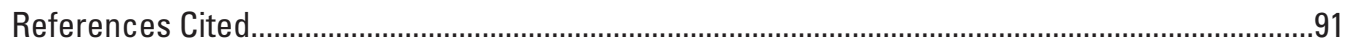

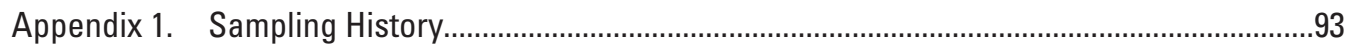

\section{Figures}

1. Image showing San Nicolas Island, California, study site locations and

December 2018 kelp-canopy expanse ............................................................................ 2

2. Schematic showing typical supersite layout...................................................................

3. Image of Nav Fac 100 supersite showing typical brown algae mix of Dictyota binghamiae, Sargassum horneri, and Cystoseira osmundacea ......................................8

4. Image of West End supersite showing erect coralline and fleshy red algal bottom cover with understory kelp and Macrocystis pyrifera..........................................9

5. Image showing rich invertebrate bottom cover at Dutch Harbor supersite ....................10

6. Image of Daytona 100 supersite showing urchin and kelp dominated areas ..................11

7. Graph showing 18-year temperature record from subtidal readings at San Nicolas Island subtidal sites.....................................................................................13

8. Boxplots showing bottom sea-floor temperature at Nav Fac and Dutch Harbor ............14

9. Graphs showing hourly bottom temperature data for Nav Fac 100 from November 22, 2015, to April 10, 2019, and the other three supersites from November 22, 2014, to April 10, 2019........................................................................15

10. Image showing the wavy turban snail with typical shell fouling of erect and encrusting coralline algae 
11. Image showing juvenile form of the invasive alga Sargassum horneri, typical of plants seen in fall.....

12. Graphs showing size distribution by sex of sheephead in fall 2014-spring 2019 ............20

13. Graphs showing size distribution of kelp bass in fall 2014-spring 2019 ..........................21

14. Graph showing mean densities of some swath-counted species that have demonstrated changing abundance at Nav Fac 100 during the last 5 years ..................23

15. Graphs showing Nav Fac 100 Macrocystis pyrifera greater than 1-meter (m) tall stipe counts by season (fall 2014-spring 2019) .........................................................25

16. Graphs showing Nav Fac 100 Macrocystis pyrifera greater than 1-meter (m) tall holdfast diameters by season (fall 2014-spring 2019).

17. Graphs showing size structure of Kellet's whelk at Nav Fac 100 in fall 2014spring 2019 .

18. Graphs showing Nav Fac 100 size structure of wavy turban snails in fall 2014spring 2019 .

19. Graphs showing Nav Fac 100 size structure of purple urchins in fall 2014spring 2019.

20. Graphs showing Nav Fac 100 size structure of red urchins in fall 2014-spring 2019 .....33

21. Graphs showing mean percent cover categories by supersite in fall 2014 through spring 2019

22. Graphs showing mean densities of some swath-counted species that have demonstrated changing abundance at West End during the last 5 years. 41

23. Graphs showing West End Macrocystis pyrifera greater than 1-meter ( $\mathrm{m})$ tall stipe counts by season in fall 2014-spring 2019.

24. Graphs showing West End Macrocystis pyrifera greater than 1 meter $(\mathrm{m})$ tall holdfast diameters by season in fall 2014-spring 2019

25. Graphs showing West End size structure of purple urchins in fall 2014-spring 2019.....47

26. Graphs showing West End size structure of red urchins in fall 2014-spring 2019 ..........48

27. Graph showing mean densities of some swath-counted species that have demonstrated changing abundance at Dutch Harbor during the last 5 years.................54

28. Graphs showing Dutch Harbor Macrocystis pyrifera greater than 1-meter (m) tall stipe counts by season in fall 2014-spring 2019 ...

29. Graphs showing Dutch Harbor Macrocystis pyrifera greater than 1-meter (m) tall holdfast diameters by season in fall 2014-spring 2019..

30. Graphs showing Dutch Harbor size structure of purple urchins in fall 2014spring 2019

31. Graphs showing Dutch Harbor size structure of red urchins in fall 2014-spring 2019...61

32. Graph showing mean densities of some swath-counted species that have demonstrated changing abundance at Daytona 100 during the last 5 years

33. Graphs showing Daytona 100 Macrocystis pyrifera greater than 1-meter (m) tall stipe counts by season in fall 2014-spring 2019 ...

34. Graphs showing Daytona 100 Macrocystis pyrifera greater than 1-meter $(\mathrm{m})$ tall holdfast diameters by season, fall 2014-spring 2019.

35. Graphs showing size structure of Kellet's whelk at Daytona 100 in fall 2014spring 2019.

36. Graphs showing Daytona 100 size structure of wavy turban snails in fall 2014spring 2019

37. Graphs showing Daytona 100 size structure of purple urchins in fall 2014spring 2019 
38. Graphs showing Daytona 100 size structure of red urchins in fall 2014-spring 2019 .....77

39. Graphs showing long-term trends in urchin abundance ................................................81

40. Graph showing kelp and fleshy red algae cover trends over time at Nav Fac ...............83

41. Graphs showing kelp and fleshy red algae cover trends over time at Daytona ..............84

42. Graph showing kelp and fleshy red algae cover trends over time at Dutch Harbor.......85

43. Graphs showing kelp and fleshy red algae cover trends over time at West End............86

44. Graph showing Megastraea undosa trends over time at West End, Dutch Harbor, and original five swaths of Nav Fac and Daytona from fall 1980 to spring 2019

45. Graph showing Pisaster giganteus trends over time at West End, Dutch Harbor, and original five swaths of Nav Fac and Daytona from fall 1980 to spring 2019

46. Graph showing Pycnopodia helianthoides trends over time at West End, Dutch Harbor, and original five swaths of Nav Fac and Daytona from fall 1980 to spring 2019

47. Graph showing Patiria miniata trends over time at West End, Dutch Harbor, and original five swaths of Nav Fac and Daytona from fall 1980 to spring 2019.

\section{Tables}

1. San Nicolas Island subtidal site waypoints (WGS84) and main transect bearings ..........4

2. Benthic swath locations relative to main transect line at each supersite ........................5

3. Species and measurements sampled on 10 -m by 2 -m swaths........................................5

4. Point contact and 1-square meter quadrat locations relative to main transect line at each supersite

5. Fish transect locations relative to main transect line at each supersite - start point and bearing.....

6. Summary of fall 2018 fish size estimates for all sites combined......................................18

7. Summary of spring 2019 fish size estimates for all sites combined ..................................19

8. Nav Fac 100 mean swath counts for fall 2014 through spring 2019 expressed as individuals per 20-square meter transect.

9. Sizes of invertebrates measured on swaths at Nav Fac 100, fall 2014 through spring 2019

10. Percentage of Strongylocentrotus purpuratus in three size bins at each supersite in fall 2014-spring 2019

11. Percentage of Strongylocentrotus franciscanus in three size bins at each supersite in fall 2014-spring 2019.

12. Mean numbers of rare species counted on twenty 1-square meter quadrats from Nav Fac 100, fall 2014 through spring 2019.

13. Nav Fac 100 point contact "species" ranked by the sum of points for fall 2014 through spring 2019 .

14. Number of fish species counted, total count, density on benthic and midwater transects, and number of fish sized at each supersite in fall 2014 through spring 2019

15. Nav Fac 100 fish counts_adult (juvenile)—in fall 2014 through spring 2019 by species

16. West End mean swath counts for fall 2014 through spring 2019 expressed as individuals per 20-square meter transect. 
17. Sizes of invertebrates measured on swaths at West End in fall 2014 through spring 2019

18. Mean numbers of rare species counted on twenty 1-square meter quadrats from West End, fall 2014 through spring 2019

19. West End point contact "species" ranked by the sum of points for fall 2014 through spring 2019

20. West End fish counts_-adult (juvenile)—in fall 2014 through spring 2019 (by species).

21. Dutch Harbor mean swath counts for fall 2014 through spring 2019 expressed as individuals per 20-square meter transect

22. Sizes of invertebrates measured on swaths at Dutch Harbor in fall 2014 through spring 2019

23. Mean numbers of rare species counted on twenty 1-square meter quadrats from Dutch Harbor in fall 2014 through spring 2019.

24. Dutch Harbor point contact "species" ranked by the sum of points for fall 2014 through spring 2019

25. Dutch Harbor fish counts_adult (juvenile) —in fall 2014 through spring 2019 (by species)......

26. Daytona 100 mean swath counts for fall 2014 through spring 2019 expressed as individuals per 20-square meter transect.

27. Sizes of invertebrates measured on swaths at Daytona 100 in fall 2014 through spring 2019

28. Mean numbers of rare species counted on twenty 1-square meter quadrats from Daytona 100 in fall 2014 through spring 2019

29. Daytona 100 point contact "species" ranked by the sum of points for fall 2014 through spring 2019

30. Daytona 100 fish counts_-adult (juvenile)—in fall 2014 through spring 2019 by species 


\section{Conversion Factors}

International System of Units to U.S. customary units

\begin{tabular}{lcl}
\hline \multicolumn{1}{c}{ Multiply } & \multicolumn{1}{c}{ By } & To obtain \\
\hline & Length & \\
\hline centimeter $(\mathrm{cm})$ & 0.3937 & inch (in.) \\
millimeter $(\mathrm{mm})$ & 0.03937 & inch (in.) \\
meter $(\mathrm{m})$ & 3.281 & foot (ft) \\
meter $(\mathrm{m})$ & 1.094 & yard (yd) \\
\hline & Area & \\
\hline square meter $\left(\mathrm{m}^{2}\right)$ & 0.0002471 & acre
\end{tabular}

Temperature in degrees Celsius $\left({ }^{\circ} \mathrm{C}\right)$ may be converted to degrees Fahrenheit $\left({ }^{\circ} \mathrm{F}\right)$ as follows:

$$
{ }^{\circ} \mathrm{F}=\left(1.8 \times{ }^{\circ} \mathrm{C}\right)+32 .
$$

\section{Datum}

Horizontal coordinate information is referenced to the World Geodetic System of 1984 (WGS84).

\section{Abbreviations}

$\begin{array}{ll}\text { RPC } & \text { random point contact } \\ \text { SNI } & \text { San Nicolas Island } \\ \text { SSWS } & \text { sea star wasting syndrome } \\ \text { USFWS } & \text { U.S. Fish and Wildlife Service } \\ \text { USGS } & \text { U.S. Geological Survey } \\ \text { WS } & \text { withering syndrome }\end{array}$





\title{
Kelp Forest Monitoring at Naval Base Ventura County, San Nicolas Island, California: Fall 2018 and Spring 2019, Fifth Annual Report
}

\author{
By Michael C. Kenner and Joseph A. Tomoleoni
}

\section{Introduction}

Kelp forests and rocky reefs are among the most recognized marine ecosystems and provide the primary habitat for several species of fishes, invertebrates, and algal assemblages (Stephens and others, 2006). In addition, kelp forests have been shown to be important carbon dioxide sinks (Wilmers and others, 2012) and are an important source of nearshore marine primary production (Duggins and others, 1989). These highly dynamic ecosystems are extremely variable, and both top-down and bottom-up ecological controls drive this rich trophic environment. Giant kelp (Macrocystis pyrifera) forests and the species that inhabit these ecosystems are influenced by several environmental conditions, such as wave exposure, water temperature, water clarity, bottom depth and composition, species composition, and the density of kelp and other algal assemblages (Schiel and Foster, 2015). However, in addition to "normal" variability, kelp forests can undergo extreme regime shifts from kelp canopy forested areas to barrens characterized by high densities of urchins and encrusting coralline algae (Harrold and Reed, 1985).

San Nicolas Island (SNI), outermost of the California Channel Islands, is home to a diverse group of terrestrial and marine organisms and includes kelp bed and rocky reef habitats (fig. 1). The SNI kelp forests not only provide food and shelter for fishes and invertebrates within the habitat, but also they support higher trophic level consumers such as marine birds and several marine mammal species including the southern sea otter (Enhydra lutris nereis), a major predator on sea urchins and other marine invertebrates.

Owing to concern about the vulnerability of the California population, the U.S. Fish and Wildlife Service (USFWS) translocated 140 southern sea otters from the central California coast to SNI between 1987 and 1990. Although only approximately 14 translocated otters are thought to have remained at SNI (U.S. Fish and Wildlife Service, 2012), their population at the island has increased and is currently greater than 120 individuals (Hatfield and others, 2019). Sea otters are a natural part of the kelp forest ecosystem, but their presence has implications for community dynamics as they repopulate a region from which they were extirpated in the 19th century. At SNI, sea otters have been concentrated mostly around the west end of the island, with some use of the south side and very little, but expanding, use of the northeast side. An ecosystem shift from urchin dominated to kelp dominated, that occurred at a site at the west end of the island in the early 2000s, though initiated by sea urchin disease, was likely facilitated to some degree by sea otter foraging (Kenner and Tinker, 2018).

These ecosystems also are the target of many fisheries, including urchin and lobster. Urchin fisheries, which target the larger red sea urchin, may release the smaller but more mobile purple sea urchin from competitive control (Dayton and others, 1998). Lobster fisheries may release purple sea urchins from predatory control (Lafferty, 2004). Owing to the distance from the mainland, however, SNI kelp forests and reefs have been somewhat protected from the degree of harvest and other anthropogenic impacts experienced by the southern California mainland. Invasive species are another issue, and there are a few invasive subtidal macroalgae of concern in southern California waters. Although the brown alga Sargassum muticum has been established at the island for decades, S. horneri has only recently been seen at SNI and, so far, the invasive kelp Undaria pinnatifida and the green alga Caulerpa taxifolia have not been observed there. Sargassum horneri, in particular, has demonstrated a capability to outcompete native kelps at some of the other Channel Islands but it is unclear what indirect effects it may have on community structure (Marks and others, 2015).

Because the surrounding kelp forests fall within the management boundary of the SNI Integrated Natural Resources Management Plan (INRMP; U.S. Navy, 2015), USGS works with the Navy to provide surveys of this ecologically important ecosystem that inform natural resource managers of trends in the population abundance of particular species. In addition, long-term surveys allow for an understanding of potential changes in species diversity and community composition as a result of trophic or other interactions. 


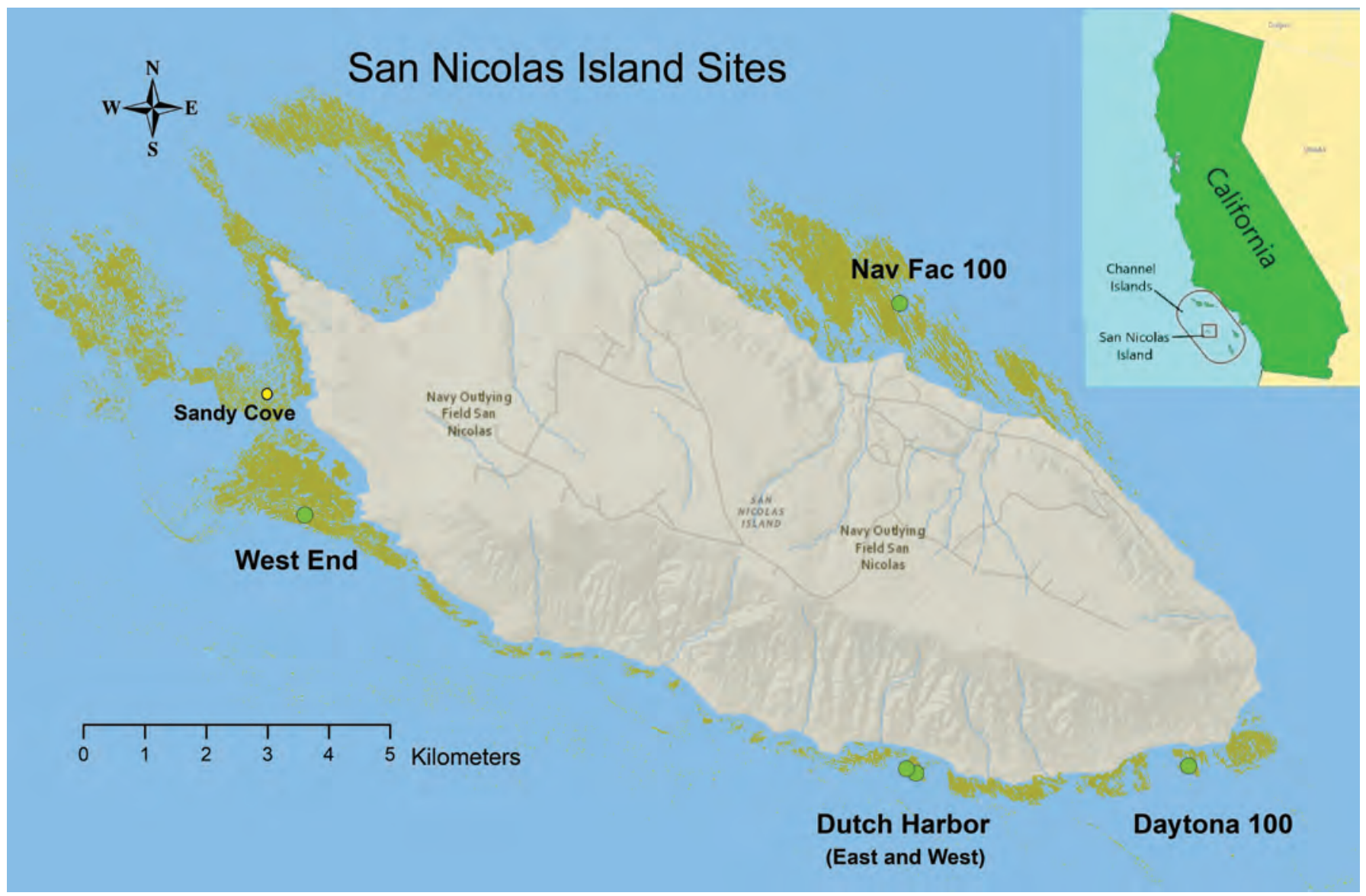

Figure 1. San Nicolas Island, California, study site locations and December 2018 kelp-canopy expanse.

The U.S. Geological Survey (USGS) implemented a kelp forest monitoring program for the U.S. Navy at San Nicolas Island in 2014, building on sites and methods established by USFWS scientists in 1980 (appendix 1). This report focuses on data collected during sampling expeditions to these sites in fall 2018 (October 2-5) and spring 2019 (April 3-6). Together they will be herein referred to as year 5 because, although the trips were made in different calendar years, they were approximately 6 months apart and were conducted under the fifth year of this contract. The previous sampling year (fall 2017 and spring 2018) is referred to as year 4 . The year 5 data are compared with data collected during eight trips from fall 2014 through spring 2018. Differences in counts between these expeditions can result from seasonal factors, stochastic variation, or sampling error, but temporal comparison can reveal population trends. Where appropriate, long-term data collected during the 33 years prior to the implementation of these slightly revised protocols will be presented in order to lend some context to the observations reported here.

Genus and species names used in this report are those currently recognized as valid in the Integrated Taxonomic Information System (ITIS.gov). Upon first use, the name recognized as valid by the World Register of Marine Species (WoRMS; marinespecies.org) is shown in brackets if different. The exception is Sargassum horneri which does not show up in any discernable form in ITIS.gov. 


\section{Methods}

\section{Site Design and Sampling Protocols}

Four permanent "supersites" were sampled at the island, and each is composed of two subunit sites (figs. 1,2). Most of these supersites were set up as part of the USGS SNI Subtidal Baseline project described in appendix 1. Associated with each of these eight subunit sites is a 50-meter $(\mathrm{m})$ main transect with five $10-\mathrm{m}$ by $2-\mathrm{m}$ benthic band transects (swaths) and ten 1-square-meter $\left(\mathrm{m}^{2}\right)$ random point contact (RPC) quadrats (see details in the following subsections). The 50-m main transects of the two subunit sites are connected in a linear fashion with the $50-\mathrm{m}$ end of one connecting to the $0-\mathrm{m}$ end of the other, except in the case of Dutch Harbor, where these segments are on adjacent reefs. As explained in appendix 1, the supersites at West End and Dutch Harbor each have ten 50-m-long fish transects, whereas Nav Fac 100 and Daytona 100 each have five 50-m fish transects (fig. 2).

At each supersite a TidbiT ${ }^{\circledR}$ v2 model UTBI-001 (Onset Computer Corporation, Bourne, Massachusetts) archival temperature logger was deployed. These were set to record at 1-hour intervals and were installed on the sea floor (10-12 m deep) at the midpoint of the $100-\mathrm{m}$ main transects at Nav Fac 100, West End and Daytona 100 and at 0 -m at East Dutch Harbor. See figure 2 for a schematic of the sampling layout at Nav Fac 100 supersite as an example and table 1 for site locations.
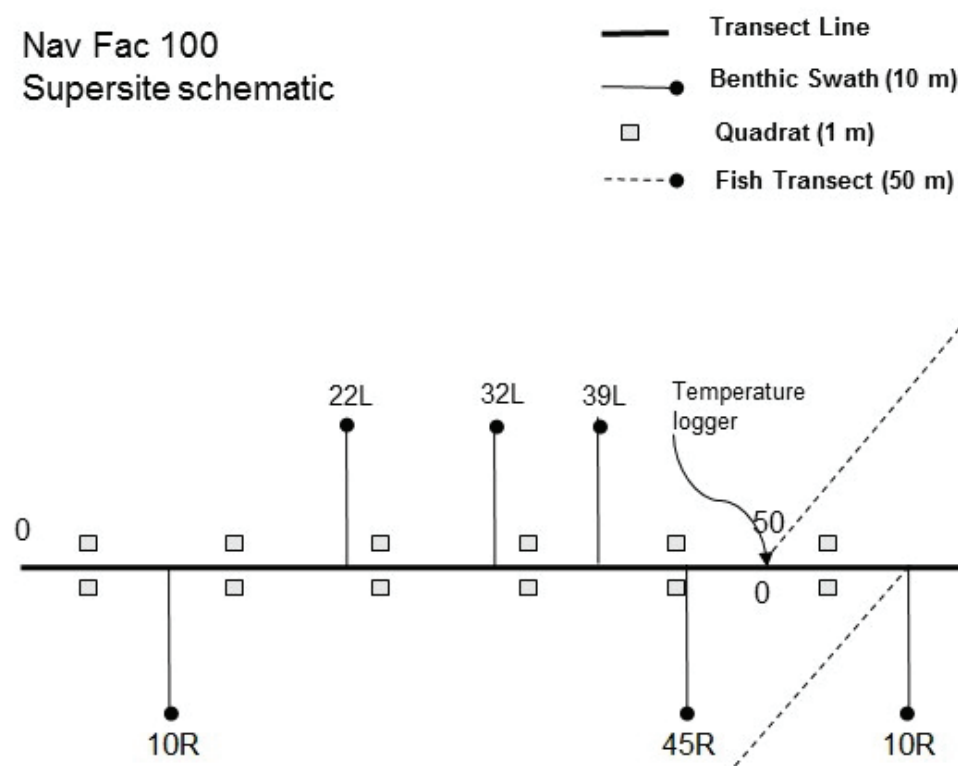

North Nav Fac (subunit 1)

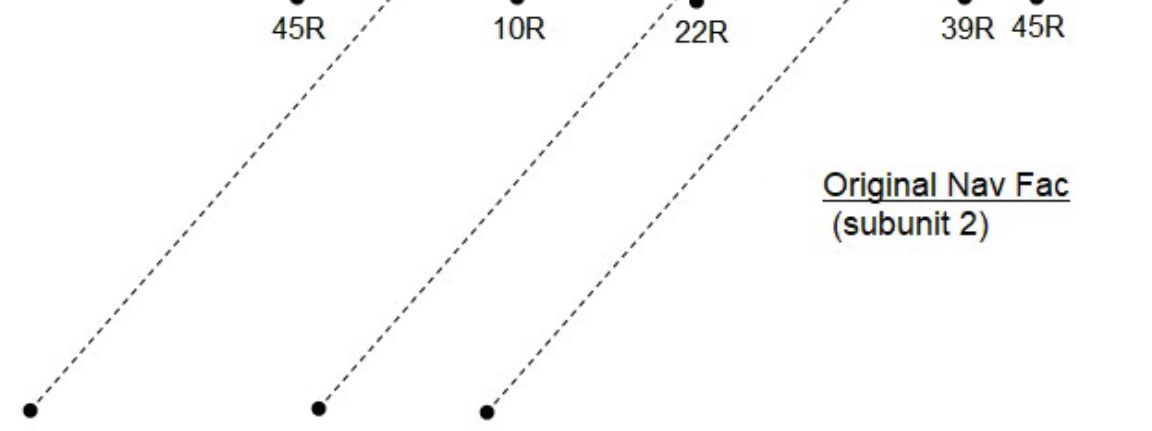

Figure 2. Typical supersite layout (Nav Fac 100). [Note that fish transects are on cardinal compass bearings and may not run perpendicular to main transect line] 
Table 1. San Nicolas Island subtidal site waypoints (WGS84) and main transect bearings.

$\left[\right.$ TidbiT $^{\circledR}$ logger location denoted by *. Abbreviations: m, meter; N, north; ${ }^{\circ}$, degrees; W, west; S, south]

\begin{tabular}{|c|c|c|c|}
\hline Marker name & Latitude & Longitude & $\begin{array}{c}\text { Transect } \\
\text { bearing }\end{array}$ \\
\hline \multicolumn{4}{|c|}{ Nav Fac 100} \\
\hline North Nav Fac $0 \mathrm{~m}$ & $\mathrm{~N} 33.27385^{\circ}$ & $\mathrm{W} 119.48681^{\circ}$ & $140^{\circ}$ \\
\hline Nav Fac 0 m/N Nav Fac 50 m* & $\mathrm{N} 33.27354^{\circ}$ & $\mathrm{W} 119.48647^{\circ}$ & $140^{\circ}$ \\
\hline Nav Fac $50 \mathrm{~m}$ & $\mathrm{~N} 33.27310^{\circ}$ & $\mathrm{W} 119.48626^{\circ}$ & \\
\hline \multicolumn{4}{|c|}{ West End } \\
\hline West End urchin $0 \mathrm{~m}$ & $\mathrm{~N} 33.24772^{\circ}$ & $\mathrm{W} 119.57419^{\circ}$ & $100^{\circ}$ \\
\hline W End kelp $0 \mathrm{~m} / \mathrm{W}$ End urchin $50 \mathrm{~m} *$ & $\mathrm{~N} 33.24762^{\circ}$ & $\mathrm{W} 119.57367^{\circ}$ & $110^{\circ}$ \\
\hline West End kelp $50 \mathrm{~m}$ & $\mathrm{~N} 33.24742^{\circ}$ & $\mathrm{W} 119.57318^{\circ}$ & \\
\hline \multicolumn{4}{|c|}{ Dutch Harbor } \\
\hline West Dutch Harbor $0 \mathrm{~m}$ & $\mathrm{~N} 33.21652^{\circ}$ & $\mathrm{W} 119.48547^{\circ}$ & $55^{\circ}$ \\
\hline West Dutch Harbor $50 \mathrm{~m}$ & $\mathrm{~N} 33.21672^{\circ}$ & $\mathrm{W} 119.48503^{\circ}$ & \\
\hline East Dutch Harbor $0 \mathrm{~m}^{*}$ & $\mathrm{~N} 33.21598^{\circ}$ & $\mathrm{W} 119.48407^{\circ}$ & $25^{\circ}$ \\
\hline East Dutch Harbor $50 \mathrm{~m}$ & $\mathrm{~N} 33.21630^{\circ}$ & $\mathrm{W} 119.48381^{\circ}$ & \\
\hline \multicolumn{4}{|c|}{ Daytona 100} \\
\hline South Daytona $0 \mathrm{~m}$ & $\mathrm{~N} 33.21643^{\circ}$ & $\mathrm{W} 119.44420^{\circ}$ & $0^{\circ}$ \\
\hline Daytona $0 \mathrm{~m} / \mathrm{S}$ Daytona $50 \mathrm{~m} *$ & $\mathrm{~N} 33.21687^{\circ}$ & $\mathrm{W} 119.44412^{\circ}$ & $0^{\circ}$ \\
\hline Daytona $50 \mathrm{~m}$ & $\mathrm{~N} 33.21731^{\circ}$ & $\mathrm{W} 119.44400^{\circ}$ & \\
\hline
\end{tabular}

\section{Swaths/Band Transects}

The swath/band transect method was used to determine densities of kelps and benthic macroinvertebrates as well as to gather size data on some of these populations. Ten permanent $10-\mathrm{m}$ by $2-\mathrm{m}$ swaths, which run perpendicular to the main $100-\mathrm{m}$ transect, were sampled by divers at each supersite. See table 2 for swath locations and orientations. Although nominally $20 \mathrm{~m}^{2}$, the actual substrate sampled per swath was more, because of reefs, undercuts, boulders and other benthic features. First, researchers attached a meter tape at a fixed point on the main transect and ran it out to an eyebolt embedded in the sea floor approximately $10 \mathrm{~m}$ away. On each swath, the divers, using meter sticks as guides, then counted the target organisms (table 3 ) that occurred within $1 \mathrm{~m}$ on either side of the tape. Divers measured in situ sea star and mollusk size (millimeters [mm]) - maximum arm length from center for sea stars (following the curve of the arm) and maximum shell length for mollusks. For giant kelp (M. pyrifera) greater than $1 \mathrm{~m}$ tall (herein referred to as adults), the divers measured the holdfast diameter at the base (centimeters $[\mathrm{cm}]$ ) and counted stipes at $1 \mathrm{~m}$ above the substrate. Holdfast diameters give an indication of the M. pyrifera age structure because the holdfast continues to grow throughout the life of the alga. Stipe counts are more variable with age but give an indication of algal biomass. Kelps of the genus Laminaria occur at SNI in a few different forms. Most of them appear to be L. farlowii or have a range of forms blending traits of $L$. farlowii (very short stipes and a single entire bullate blade) and $L$. setchellii (a single smooth but divided blade with a tall stiff stipe) but very few of them are obviously L. setchellii (Abbott and Hollenberg, 1976). For this reason, these kelps are tallied and presented as "Laminaria spp." Note that in the referenced text, L. setchellii is erroneously referred to as L. dentigera.

We measured the test diameter (millimeters) of a subsample of sea urchins (Strongylocentrotus spp.) - about 200 per species per supersite. Divers did not measure urchins on swaths but instead measured them in situ near the main transect. The urchins were measured as they were encountered to avoid size selective bias. 
Table 2. Benthic swath locations relative to main transect line at each supersite.

[R or $\mathrm{L}$ indicates the swath is to the right or left of main transect when facing from $0 \mathrm{~m}$ to $50 \mathrm{~m}$. Note that the 45R swath at Daytona was lost owing to sand burial in 1983 , so the $22 \mathrm{~L}$ swath was set up 2 years later as a replacement.]

\begin{tabular}{lccccc}
\hline $\begin{array}{c}\text { Supersite and } \\
\text { sites }\end{array}$ & \multicolumn{5}{c}{ Swaths } \\
\hline \multicolumn{5}{c}{ Nav Fac 100 } \\
\hline Nav Fac & $10 \mathrm{R}$ & $22 \mathrm{R}$ & $32 \mathrm{~L}$ & $39 \mathrm{R}$ & $45 \mathrm{R}$ \\
North Nav Fac & $10 \mathrm{R}$ & $22 \mathrm{~L}$ & $32 \mathrm{~L}$ & $39 \mathrm{~L}$ & $45 \mathrm{R}$ \\
\hline \multicolumn{5}{c}{ West End } \\
\hline West End urchin & $10 \mathrm{~L}$ & $22 \mathrm{~L}$ & $32 \mathrm{R}$ & $39 \mathrm{~L}$ & $45 \mathrm{~L}$ \\
West End kelp & $10 \mathrm{R}$ & $22 \mathrm{R}$ & $32 \mathrm{~L}$ & $39 \mathrm{R}$ & $45 \mathrm{~L}$ \\
\hline \multicolumn{5}{c}{ Dutch Harbor } \\
\hline West Dutch & $10 \mathrm{R}$ & $22 \mathrm{~L}$ & $32 \mathrm{~L}$ & $39 \mathrm{~L}$ & $45 \mathrm{~L}$ \\
East Dutch & $10 \mathrm{R}$ & $22 \mathrm{R}$ & $32 \mathrm{~L}$ & $39 \mathrm{R}$ & $45 \mathrm{R}$ \\
\hline \multicolumn{5}{c}{ Daytona 100 } \\
\hline Daytona & 10R & 22R & 22L & $32 \mathrm{~L}$ & $39 \mathrm{~L}$ \\
South Daytona & $10 \mathrm{R}$ & $22 \mathrm{~L}$ & $32 \mathrm{R}$ & $39 \mathrm{R}$ & $45 \mathrm{R}$ \\
\hline
\end{tabular}

Table 3. Species and measurements sampled on 10-m by 2-m swaths.

[* Measured off swaths. Abbreviations: mm, millimeter; m, meter; $\mathrm{cm}$, centimeter; $<$, less than; $>$, greater than]

\begin{tabular}{|c|c|c|}
\hline Species name & Common name & Measurement \\
\hline $\begin{array}{l}\text { Strongylocentrotus } \\
\text { franciscanus }\end{array}$ & Red urchin & Test diameter $(\mathrm{mm})^{*}$ \\
\hline $\begin{array}{l}\text { Strongylocentrotus } \\
\text { purpuratus }\end{array}$ & Purple urchin & Test diameter $(\mathrm{mm})^{*}$ \\
\hline Lytechinus anamesus & White urchin & Test diameter (mm) \\
\hline Apostichopus parvimensis & Warty sea cucumber & None \\
\hline Pycnopodia helianthoides & Sunflower star & $\begin{array}{l}\text { Longest ray length from } \\
\text { center }(\mathrm{mm})\end{array}$ \\
\hline Patiria miniata & Bat star & $\begin{array}{l}\text { Longest ray length from } \\
\text { center }(\mathrm{mm})\end{array}$ \\
\hline Pisaster giganteus & Giant spined star & $\begin{array}{l}\text { Longest ray length from } \\
\text { center }(\mathrm{mm})\end{array}$ \\
\hline Astrometis sertulifera & Fragile rainbow star & $\begin{array}{l}\text { Longest ray length from } \\
\text { center }(\mathrm{mm})\end{array}$ \\
\hline Dermasterias imbricata & Leather star & $\begin{array}{l}\text { Longest ray length from } \\
\text { center }(\mathrm{mm})\end{array}$ \\
\hline Haliotis corrugata & Pink abalone & Shell length (mm) \\
\hline Haliotis rufescens & Red abalone & Shell length (mm) \\
\hline Megathura crenulata & Giant keyhole limpet & Shell length (mm) \\
\hline Megastraea undosa & Wavy turban snail & Shell base diameter $(\mathrm{mm})$ \\
\hline Kelletia kelletii & Kellet's whelk & Shell length (mm) \\
\hline Crassadoma gigantea & Rock scallop & Shell width $(\mathrm{mm})$ \\
\hline Aplysia californica & California sea hare & None \\
\hline Tealia lofotensis & White-spotted rose anemone & None \\
\hline Tethya aurantia & Puffball sponge & None \\
\hline Cystoseira osmundacea & Bladder-chain kelp & None \\
\hline Eisenia arborea & Southern sea palm & None \\
\hline Laminaria spp. & Oar weed & None \\
\hline $\begin{array}{l}\text { Macrocystis pyrifera } \\
\quad<1 \mathrm{~m}\end{array}$ & Giant kelp juvenile & None \\
\hline $\begin{array}{l}\text { Macrocystis pyrifera } \\
\quad>1 \mathrm{~m}\end{array}$ & Giant kelp adult & $\begin{array}{l}\text { Holdfast diameter }(\mathrm{cm}) \\
\text { and stipe count }\end{array}$ \\
\hline Pterygophora californica & California sea palm & None \\
\hline Sargassum horneri & Devil weed & None \\
\hline Young Laminariales & Unidentified juvenile kelp & None \\
\hline
\end{tabular}




\section{Random Point Contact (RPC) Sampling}

Random Point Contact (RPC) sampling was used to estimate cover of exposed substrate as well as cover of algae and (primarily) non-motile invertebrates. Benthic percent cover data were collected in $1-\mathrm{m}^{2}$ permanent quadrats placed $1 \mathrm{~m}$ to the left or right of the main transect at 20 fixed locations at each supersite. Within each quadrat, 20 points were distributed in a fixed pattern, each representing an estimate of 5-percent cover. Divers identified all organisms that intersected with an imaginary line running vertically through each point up to 1 meter above the substratum. Each species was scored only once per point, even if multiple individuals of the same species intersected that point. Because of this method of scoring multiple layers, total cover of all species often exceeded 100 percent, but the cover of any individual species could not be greater than 100 percent (20 points). The list of taxa recorded was open and ranged from actual individual species to species groups, for example, "orange encrusting sponge." Substrate type (bare rock or sand) also was scored if exposed. In order to access affixed species or substrate beneath them, motile invertebrate species were removed if possible but were scored in the cases of ophiuroids (brittle stars) and small holothurians (sea cucumbers). See table 4 for quadrat locations and orientations.

\section{1-Meter Quadrats}

The 1-m² quadrats, which define the location of the RPC sampling, also were used to sample densities of certain smaller species that are rare or difficult to count on swaths. Unlike the RPC sampling, which yields a measure of cover, these were actual counts of individuals. Within each quadrat, divers counted Norris's top snails (Norrisia norrisii), any Tegula species observed, red turban snails (Lithopoma gibberosa [Pomaulax gibberosus]), chestnut cowries (Cypraea spadicea [Neobernaya spadicea]), stalked tunicates (Styela montereyensis), Kellet's whelks (Kelletia kelletii), white-spotted rose anemones (Tealia lofotensis [Urticina equis]), orange puffball sponges (Tethya aurantia [T. californiana]) and the invasive brown alga (Sargassum horneri). These last four species also were counted on swaths.

Table 4. Point contact and 1-square meter quadrat locations relative to main transect line at each supersite.

[R or $\mathrm{L}$ indicates the swath is to the right or left of main transect when facing from 0 meter $(\mathrm{m})$ to $50 \mathrm{~m}$.]

\begin{tabular}{|c|c|c|c|c|c|c|c|c|c|c|}
\hline $\begin{array}{c}\text { Supersite and } \\
\text { sites }\end{array}$ & \multicolumn{10}{|c|}{ Quadrats } \\
\hline \multicolumn{11}{|c|}{ Nav Fac 100} \\
\hline Nav Fac & R05 & L05 & $\mathrm{R} 15$ & L15 & $\mathrm{R} 25$ & L25 & R35 & L35 & $\mathrm{R} 45$ & L45 \\
\hline North Nav Fac & R05 & L05 & $\mathrm{R} 15$ & L15 & $\mathrm{R} 25$ & L25 & R35 & L35 & $\mathrm{R} 45$ & L45 \\
\hline \multicolumn{11}{|c|}{ West End } \\
\hline West End urchin & R05 & L05 & $\mathrm{R} 10$ & L10 & $\mathrm{R} 15$ & L15 & $\mathrm{R} 25$ & L25 & R35 & L35 \\
\hline West End kelp & R05 & L05 & R10 & L10 & $\mathrm{R} 20$ & L20 & L25 & L40 & $\mathrm{R} 45$ & L45 \\
\hline \multicolumn{11}{|c|}{ Dutch Harbor } \\
\hline West Dutch & $\mathrm{R} 10$ & $\mathrm{R} 15$ & L15 & L20 & R25 & L25 & L30 & R35 & L35 & $\mathrm{R} 40$ \\
\hline East Dutch & R05 & L05 & $\mathrm{R} 10$ & L10 & $\mathrm{R} 15$ & L15 & $\mathrm{R} 25$ & L25 & R35 & L35 \\
\hline \multicolumn{11}{|c|}{ Daytona 100} \\
\hline Daytona & R05 & L05 & $\mathrm{R} 10$ & L10 & $\mathrm{R} 15$ & $\mathrm{~L} 15$ & $\mathrm{R} 25$ & $\mathrm{~L} 25$ & R35 & L35 \\
\hline South Daytona & R05 & L05 & $\mathrm{R} 10$ & L15 & $\mathrm{R} 25$ & L25 & R35 & L35 & $\mathrm{R} 45$ & L45 \\
\hline
\end{tabular}




\section{Visual Fish Transects}

The purpose of the fish transects was to estimate fish density, size, sex (if obviously sexually dimorphic), and vertical distribution in the water column. The fish transects were $50 \mathrm{~m}$ long with a fixed beginning point along the main site transect and a permanently chosen compass heading. Except for those which follow the main transect line, these headings are north, south, east or west and may be as much as 40 degrees $\left(^{\circ}\right)$ off of perpendicular to the main transect line (fig. 2). The midwater and bottom portions of each transect were sampled separately. Midwater transects were $5 \mathrm{~m}$ wide and encompassed the entire water column except the bottom $2 \mathrm{~m}$. Bottom transects were $2 \mathrm{~m}$ wide and included only the bottom $2 \mathrm{~m}$ of the water column. Divers attached a meter tape at the specified location on the main transect line and swam the prescribed compass heading, identifying, counting, and estimating size of all conspicuous fishes on each transect. If sex was visually distinguishable, as in the case of kelp greenling (Hexagrammos decagrammus) or California sheephead (Semicossyphus pulcher), this was recorded as well. Juveniles also were recorded separately when morphologically distinct. Divers estimated total length (TL) of small fish (less than 20-centimeter [cm] TL) to the nearest $1 \mathrm{~cm}$ and larger fish (greater than $20 \mathrm{~cm}$ ) to the nearest $5-\mathrm{cm}$ interval. For schools of a species, a size range was recorded. As described earlier in the text, Nav Fac 100 and Daytona 100 each have 5 fish transects, but West End and Dutch Harbor each have 10. At Dutch Harbor, owing to high counts typically recorded there, fish only were sized on two midwater and two bottom transects at the West Dutch Harbor site and two of each at the East Dutch Harbor site. Counts without size estimations were done on the remaining transects there. See table 5 for fish transect locations and headings.

Table 5. Fish transect locations relative to main transect line at each supersite—start point and bearing.

[* Fish not sized on these transects; ON means transect is on the main line. Abbreviations: m, meter; E, east; W, west; N, north; S, south]

\begin{tabular}{|c|c|c|c|c|c|}
\hline \multirow{2}{*}{$\begin{array}{l}\text { Supersite and } \\
\text { sites }\end{array}$} & \multicolumn{5}{|c|}{ Transects } \\
\hline & 1 & 2 & 3 & 4 & 5 \\
\hline \multicolumn{6}{|c|}{ Nav Fac 100} \\
\hline Nav Fac & $0-\mathrm{m} \mathrm{E}$ & $10-\mathrm{m} \mathrm{W}$ & 20-m E & 30-m W & 40-m W \\
\hline \multicolumn{6}{|c|}{ West End } \\
\hline West End urchin & $0-\mathrm{m} \mathrm{N}$ & $10-\mathrm{m} \mathrm{N}$ & $20-\mathrm{m} \mathrm{N}$ & $30-\mathrm{m} \mathrm{N}$ & $\mathrm{ON}$ \\
\hline West End kelp & $0-\mathrm{m} \mathrm{S}$ & $10-\mathrm{m} \mathrm{N}$ & $20-\mathrm{m} \mathrm{S}$ & $30-\mathrm{m} \mathrm{N}$ & $\mathrm{ON}$ \\
\hline \multicolumn{6}{|c|}{ Dutch Harbor } \\
\hline West Dutch & $0-\mathrm{m} \mathrm{W}$ & $10-\mathrm{m} \mathrm{W}$ & $30-\mathrm{m} \mathrm{W}^{*}$ & $45-\mathrm{m} \mathrm{W}^{*}$ & $\mathrm{ON}^{*}$ \\
\hline East Dutch & $0-\mathrm{m} \mathrm{E}$ & $10-\mathrm{m} \mathrm{W}$ & 20-m E* & $30-\mathrm{m} \mathrm{W}^{*}$ & 40-m E* \\
\hline \multicolumn{6}{|c|}{ Daytona 100} \\
\hline Daytona & 0 -m E & $0-\mathrm{m} \mathrm{W}$ & 10-m E & 20-m W & $30-\mathrm{m} \mathrm{E}$ \\
\hline
\end{tabular}




\section{Supersite Descriptions}

See table 1 for subunit site coordinates and transect orientations and figure 1 for supersite locations.

\section{Nav Fac 100}

The Nav Fac 100 supersite is situated on the north side of the island. It is exposed to the prevailing northwest swell and wind and has a generally flat bottom with a few 1-2 $\mathrm{m}$ high ledges and undercuts. The TidbiT ${ }^{\circledR}$ logger was deployed at approximately $12 \mathrm{~m}$ in depth. From the time that the original Nav Fac site (the southern $50 \mathrm{~m}$ of the supersite) was established in fall 1980 until 1989, it was kelp dominated with the bottom largely covered by encrusting and erect coralline algae, the fucoid alga (Cystoseira osmundacea), and the tube building snail, Serpulorbis squamiger [Thylocodes sqamigerus]. Kelps were common, including understory kelps Laminaria spp. and Pterygophora californica and canopy-forming giant kelp, $M$. pyrifera. By the spring of 1990, a strong recruitment of the purple sea urchin
(Strongylocentrotus purpuratus) had transformed most of the site to an urchin barren. Though urchin densities fluctuated over time, the west side of the site did not recover to a kelp dominated state. That part of the site is very flat, and the bottom is composed of soft sandstone, which may impede kelp recovery because there is no barrier to urchin movement and storms easily remove kelp holdfasts. The east side of the site has slightly higher relief and C. osmundacea, . californica, and Laminaria spp. are common there. Fish densities generally have been low throughout the site, although the more rugose eastern portion of the site appears to support more fish than the flat western side of the main transect line. The new part of the supersite (North Nav Fac), which was established in fall 2014, included some kelp dominated and some urchin dominated areas and had swaths and quadrats in both states. Urchin densities fell after the spring 2015 sampling trip and have remained low since then. Kelp recovery, however, has been slow, but $C$. osmundacea and various annual brown algae have covered large areas (fig. 3). The invasive brown alga S. horneri, which had not been observed at SNI before, first appeared at the site in fall 2015.

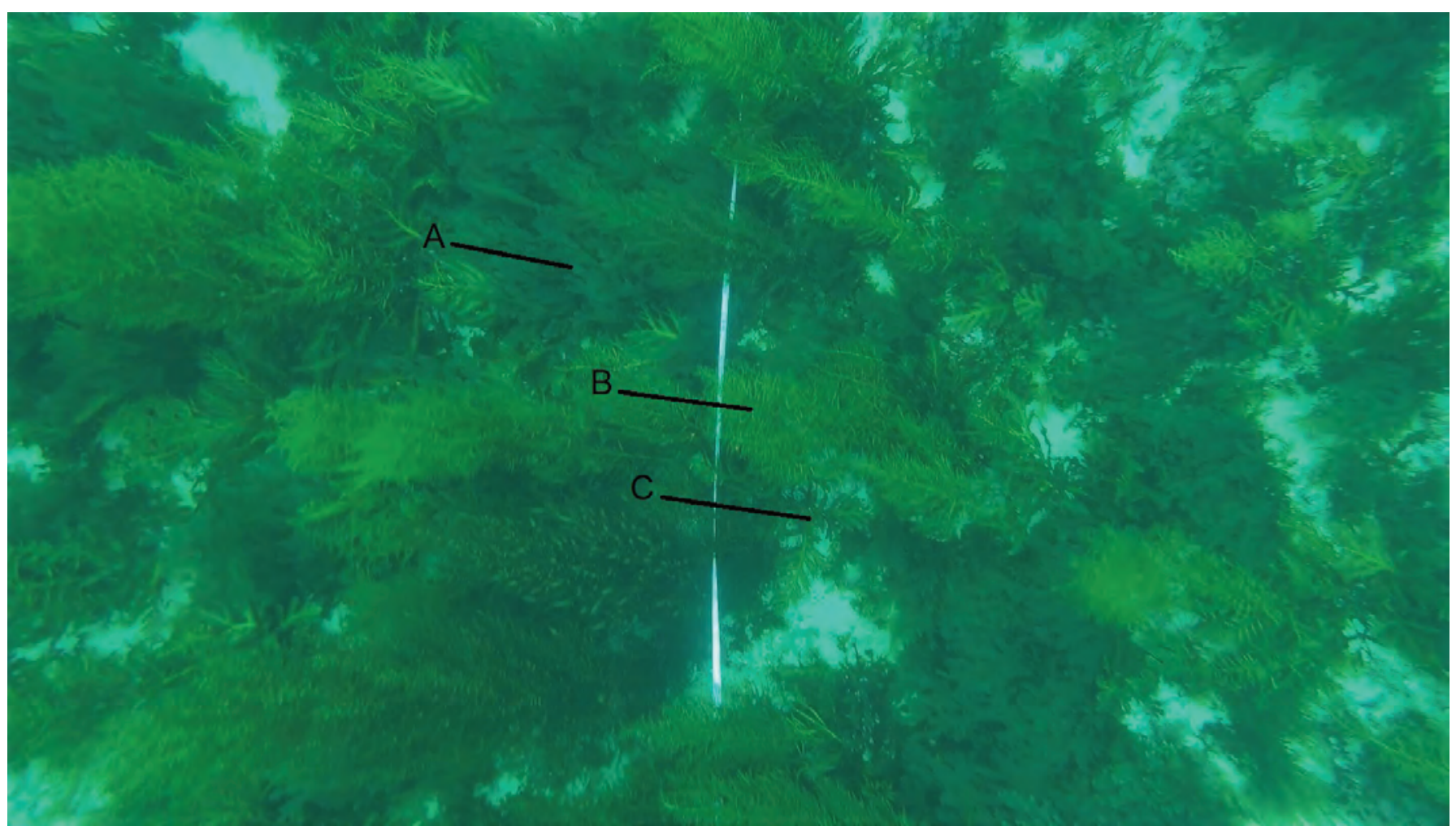

Figure 3. Nav Fac 100 supersite showing typical brown algae mix of $A$, Dictyota binghamiae; $B$, Sargassum horneri; and $C$, Cystoseira osmundacea, April 2019 (captured from video by Shannon Myers). Area shown is approximately 1 by 2 meters. 


\section{West End}

The West End supersite is located off the southwest shore of the island. The bottom there generally is flat with scattered about $1-\mathrm{m}$ boulders and sand patches. The TidbiT ${ }^{\circledR}$ logger was deployed at a depth of about $11 \mathrm{~m}$. The supersite is very exposed to prevailing northwest swell and wind. Originally designed with one $50-\mathrm{m}$ transect installed in an urchin dominated area and one in a kelp dominated area, this dynamic region has undergone several shifts between kelp and urchin states since sampling began there in 1980. In
2001, it underwent a dramatic shift from an entirely urchin dominated state to one in which they were almost entirely absent. The cause of this shift remains unclear but likely was some combination of an undocumented sea urchin disease and the foraging of sea otters that frequent the area. Since 2001, the high density of $M$. pyrifera that recruited early on has largely given way to high densities of understory kelps and high bottom cover of fleshy red algae (fig. 4). Urchin densities, although higher the last several years than during the first decade following the $2001 \mathrm{crash}$, remain low at this site, and fish densities are moderate.

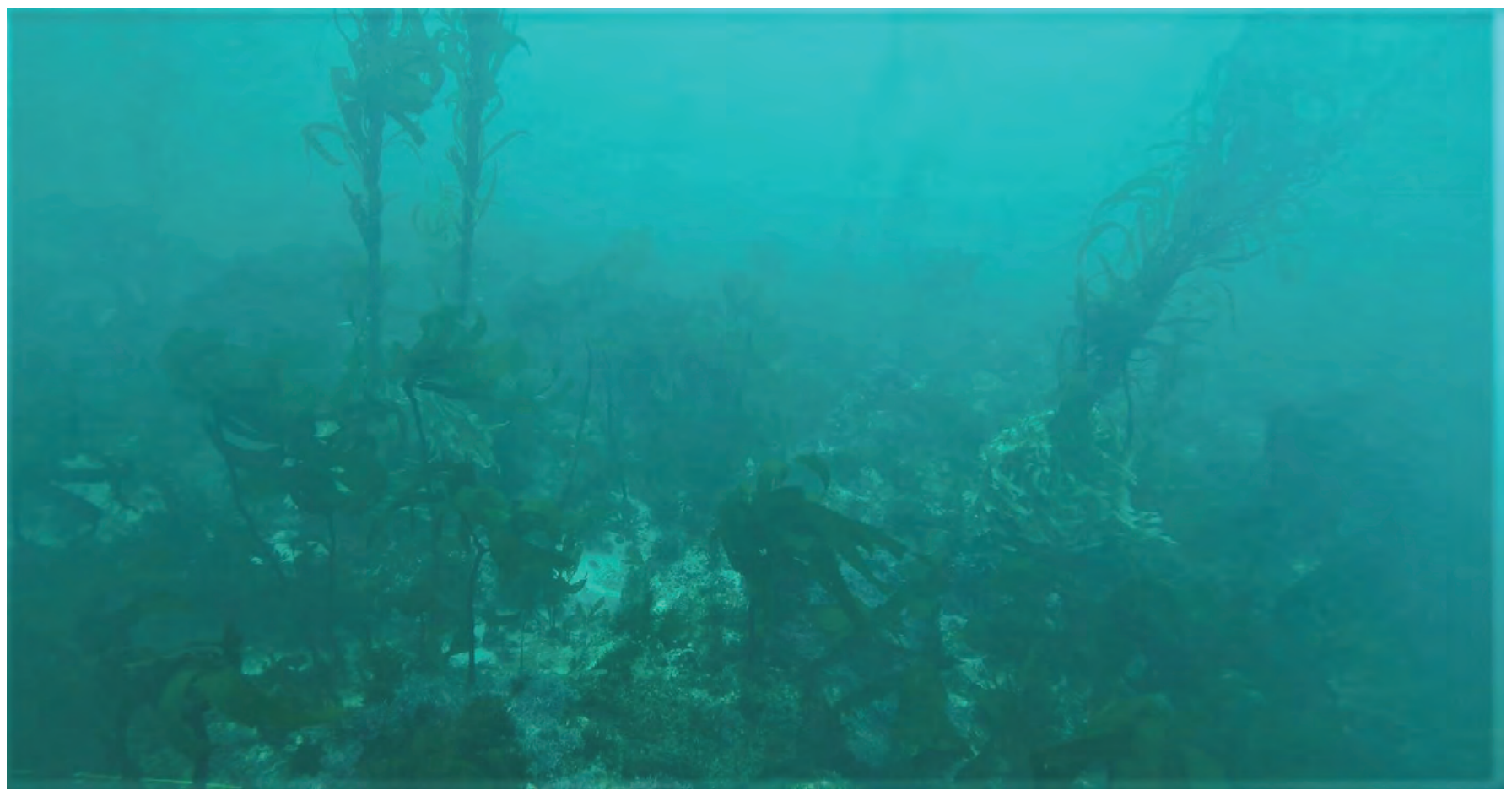

Figure 4. West End supersite showing erect coralline and fleshy red algal bottom cover with understory kelp (center and left) and Macrocystis pyrifera (upper left and right), April 2019 (captured from video by Shannon Myers). 


\section{Dutch Harbor}

The two 50-m transects at the Dutch Harbor supersite are on adjacent, roughly parallel reefs separated by about $140 \mathrm{~m}$ of sand. This supersite is located on the south side of the island. Depth along the transects ranges from about 11 to $13 \mathrm{~m}$, and the TidbiT ${ }^{\circledR}$ logger is at approximately $11 \mathrm{~m}$ at the East Dutch Harbor subunit site. The swaths traverse high-relief reefs up to $4 \mathrm{~m}$ in height with abundant cracks and ledges. The area is exposed to occasional south swell and the prevailing west wind. This supersite, remarkable for its high-relief reefs, high densities of filter feeding invertebrates (fig. 5), and high fish densities has remained the most stable of the sites over the long term (Kenner and Tinker, 2018). It has never exhibited urchin "outbreaks," and kelp densities have remained moderate and mixed with many encrusting invertebrates and small holothurians.

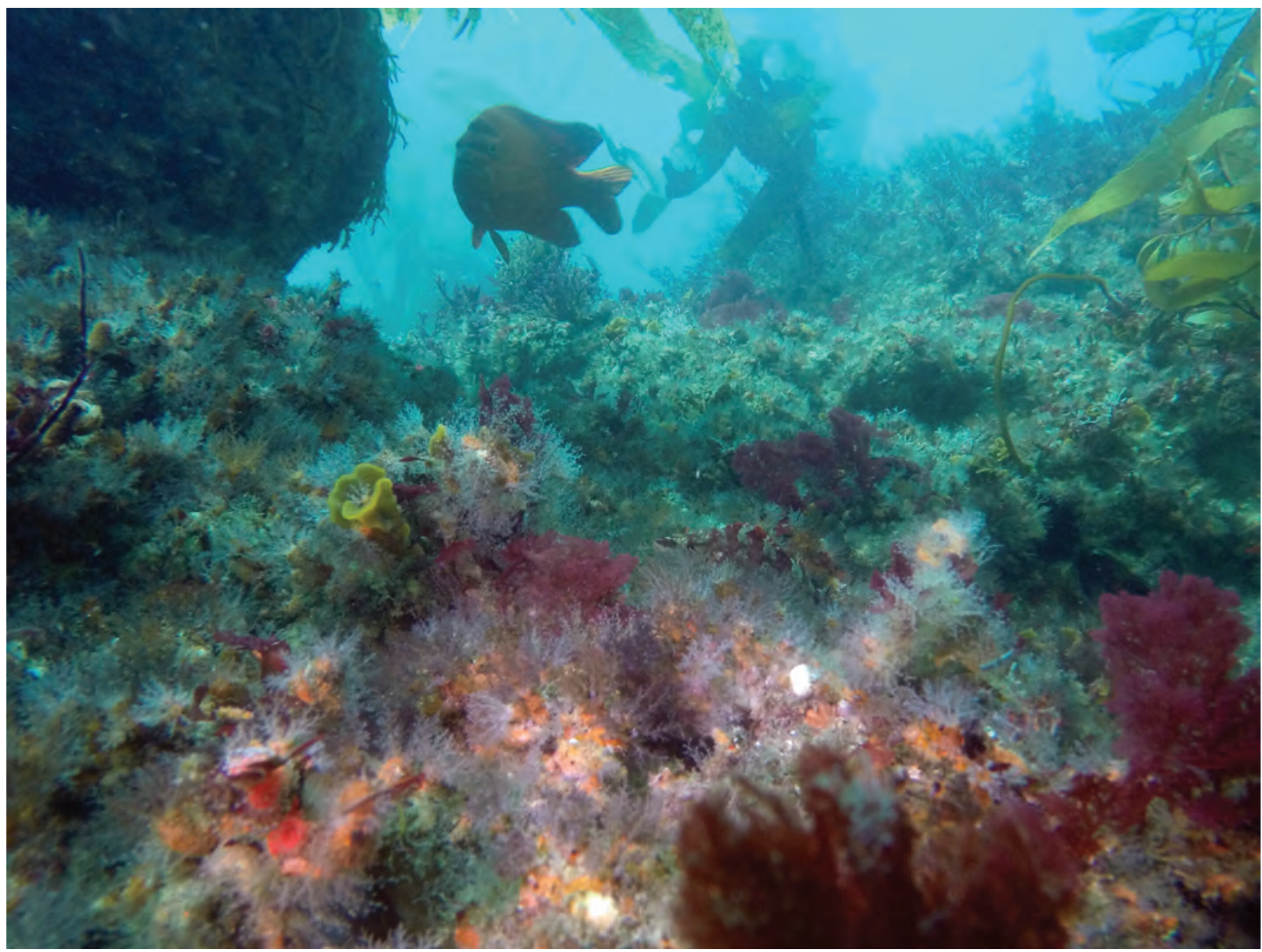

Figure 5. Rich invertebrate bottom cover at Dutch Harbor supersite, October 2018 (photograph by Zach Randell). 


\section{Daytona 100}

Located at the southeast side of the island, depths along the Daytona 100 transect are about $10-12 \mathrm{~m}$ with the TidbiT ${ }^{\circledR}$ logger at about $10 \mathrm{~m}$. The supersite generally is flat with some 1-2 m ledges and boulders. The South Daytona subunit site, established in fall 2014, has somewhat higher relief and greater depth than the original Daytona site (northern $50 \mathrm{~m}$ ). The area is exposed to occasional south swell. The prevailing wind blows offshore, so wind waves are usually small. The original Daytona site first became a purple urchin barren in the mid-1990s. After a few years, it returned to an algal-dominated state but again changed to an urchin barren soon after. Since that time, it has retained patches of urchin-dominated areas intermixed with patches of kelp-dominated areas (fig. 6). Moderate to high fish densities are typical here. In the early 1980 s, there was considerable sand movement in this area probably resulting from the old barge landing operation which, prior to construction of the pier, required heavy equipment to move beach sand to enable vehicles to drive off the barge. Sand movement is less apparent since completion of the pier in 2005 .

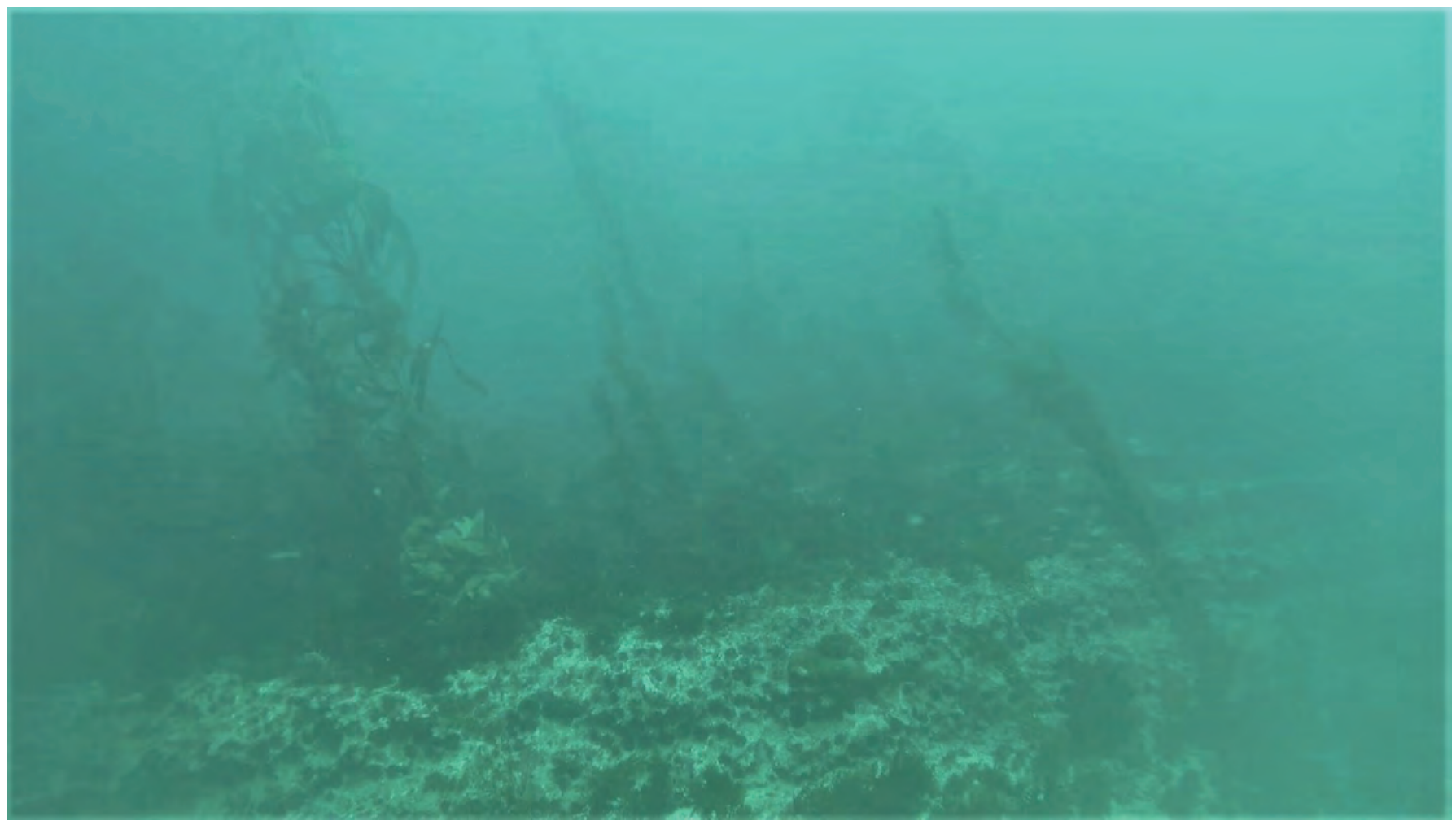

Figure 6. Daytona 100 supersite showing urchin and kelp dominated areas, April 2019 (captured from video by Shannon Myers). 


\section{Trip Conditions and Accomplishments}

The fall 2018 trip took place October 2-5. A moderate long-period south swell and winds ranging up to 25 knots resulted in mostly fair to good diving conditions, moderate surge, and 5-8 m visibility. The Daytona 100 supersite was sampled under less favorable conditions with strong surge and poor visibility (ranging from 3 to $5 \mathrm{~m}$ ). Water temperatures for the trip were about $16-17$ degrees Celsius $\left({ }^{\circ} \mathrm{C}\right)$. We completed all sampling at the four supersites and downloaded and redeployed the TidbiT ${ }^{\circledR}$ archival temperature logger at each.

The Macrocystis surface canopy was very sparse at all sites.

The spring 2019 sampling was conducted April 3-6. Winds generally were calm and the swell was moderate. Visibility was average, ranging from about $8-10 \mathrm{~m}$. Water temperature was about $14{ }^{\circ} \mathrm{C}$. We were again able to complete all sampling at the four supersites and download and redeploy the temperature loggers. Surface kelp canopies were absent at Nav Fac 100 and light at West End, Daytona 100, and Dutch Harbor.

\section{Results}

\section{Island Wide}

In 2018, mean sea temperatures were similar to the previous 2 years but about $1{ }^{\circ} \mathrm{C}$ cooler than in 2015 . The maximum temperature recorded was slightly higher than in the previous 2 years though, and the range was again greater than was recorded in most previous years (fig. 7). Boxplots of bottom temperatures recorded at Nav Fac since 2006 and Dutch Harbor since 2012 are shown in figure 8. Each box represents a complete calendar year, so no plot is shown where there were missing months of data. Though the maximum is often higher than at Nav Fac, the mean, median, and other metrics are lower at Dutch Harbor in every year there is comparable data. Although temperatures at these two sites have declined since the 2014-15 El Niño, they are still higher than pre-El Niño conditions. In fact, the average annual mean temperature was approximately $1.1^{\circ} \mathrm{C}$ higher in 2016-18 $\left(15.45^{\circ} \mathrm{C}\right.$ at Nav Fac and $15.08^{\circ} \mathrm{C}$ at Dutch Harbor) than for the years preceding the El Niño $\left(14.44{ }^{\circ} \mathrm{C}\right.$ during 2006-13 at Nav Fac and $14.03{ }^{\circ} \mathrm{C}$ during 2012-13 at Dutch Harbor). Temperature data recorded at three of the supersites from fall 2014 until spring 2019 and at Nav Fac 100 from fall 2015 until spring 2019 are shown in figure 9 (the temperature logger at Nav Fac 100 was lost after placement in fall 2014 and not replaced until fall 2015). Like in past years, late spring and early summer temperatures fluctuated on the order of $5{ }^{\circ} \mathrm{C}$ during an hour or two, possibly as a result of cold-water upwelling.
Counts of the large gastropod Megastraea undosa (fig. 10) have increased by an order of magnitude at all the supersites during the last 5 years. They have become particularly numerous at Nav Fac 100 where mean counts now exceed 50 per $20-\mathrm{m}^{2}$ swath. The density of the fucoid C. osmundacea also has increased at Nav Fac 100 and recently at Daytona 100 as well. The trend observed in year 4 (spring 2018) of increasing purple urchin densities leveled off at Nav Fac 100 and Dutch Harbor but continued in year 5 at West End and Daytona 100. Strongylocentrotus purpuratus densities at the latter supersite exceeded 1,000 per 20- $\mathrm{m}^{2}$ swath, and large patches were dominated by the herbivores. As mentioned earlier, kelp surface canopies were sparse at all sites, but at Nav Fac 100 and Dutch Harbor, the counts of Macrocystis on transects were very low as well. The cover of fleshy red algae has declined recently at all sites except at Nav Fac 100, where it was already rare.

The invasive brown alga $S$. horneri was first observed in California at Long Beach Harbor in 2003 and at Catalina Island 3 years later (Miller and others, 2007). By the spring of 2015, it had been observed at five of the Channel Islands and at several areas along the California coast from Santa Barbara south to Isla Natividad in Baja California (Marks and others, 2015). It was first seen at SNI in low numbers at Nav Fac 100 in fall 2015 (Kenner, 2016) and has been recorded on every subsequent visit there. Typically, relatively low numbers are recorded in fall when plants are small (fig. 11); by spring, counts increase several-fold and because this annual alga produces copious reproductive fronds, cover increases dramatically. In spring 2019, however, densities of reproductive plants were considerably lower than the previous two spring seasons. It is not clear why this change occurred. Sargassum horneri has not been observed at any of the other SNI subtidal monitoring sites but has been seen attached at intertidal sites near Cosign Cove on the west end of SNI (S. Graham, unpub. data, 2020).

No abalone (Haliotis spp.) were counted at any of the sites in year 5 and only five have been counted since 2002 (four H. rufescens and one $H$. corrugata). Prior to the mid-1990s, island-wide total abalone counts of both species at the original six USGS sites were usually in the teens to low twenties. The timing of their decline corresponded with the decimation of the intertidal black abalone population on SNI by withering syndrome (WS; VanBlaricom and others, 1993), and the disease is known to have affected other abalone species. Because WS was not observed in subtidal habitats at $\mathrm{SNI}$, however, it is possible fishing pressure or other factors may have contributed to the decline. Although sea otters could have played a part in reducing $H$. rufescens and $H$. corrugate density, sea otter numbers and distribution at the time make that unlikely. 


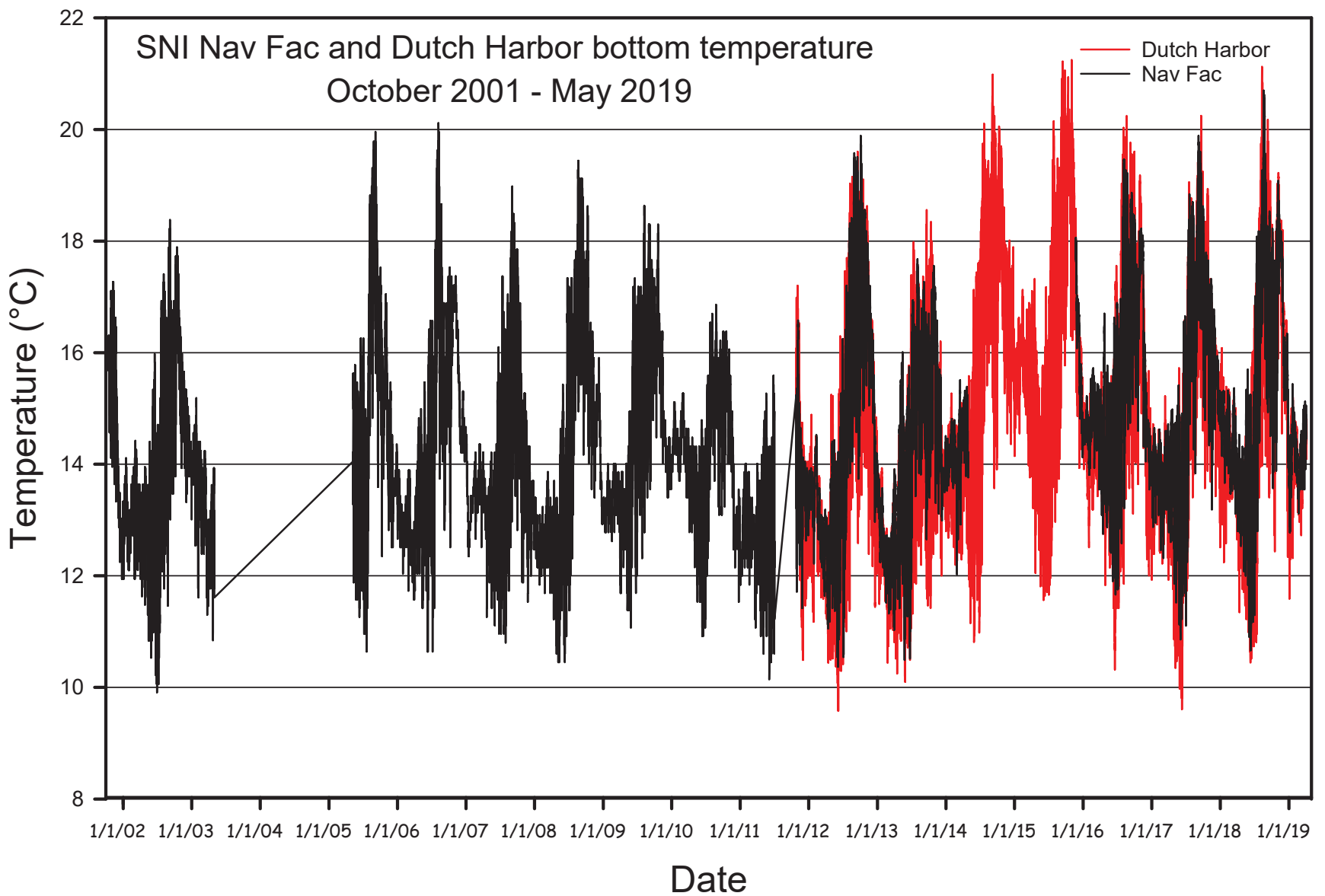

Figure 7. Eighteen-year temperature record from subtidal readings at San Nicolas Island subtidal sites. [Hourly temperature data from Nav Fac at 12-m depth from October 2001 to April 2019 (in black)—but note periods of missing data—and Dutch Harbor (in red) at 11-m depth from October 2011-April 2019] 


\section{Long-term bottom temperatures \\ Calendar year - Dutch Harbor}

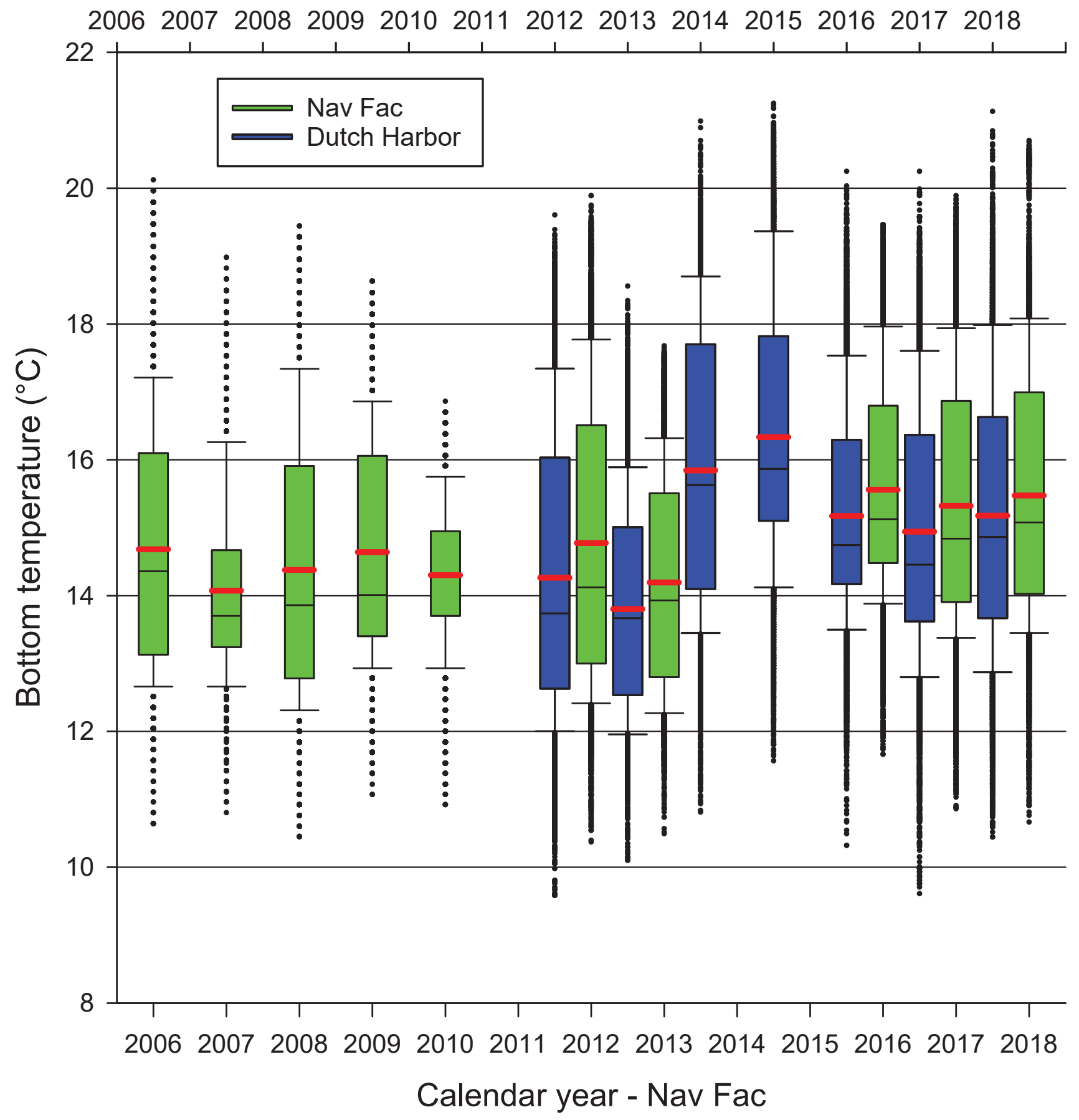

Figure 8. Annual bottom temperature at Nav Fac and Dutch Harbor. [The red line is the mean, the black line is the median, the box boundaries designate the 25th and 75th percentiles, and the caps on the whiskers are the 10th and 90th percentile. Outlying points are plotted beyond whisker caps and prior to 2012 have a dotted appearance because earlier data is only to nearest 0.1 degree Celsius $\left.\left({ }^{\circ} \mathrm{C}\right)\right]$ 

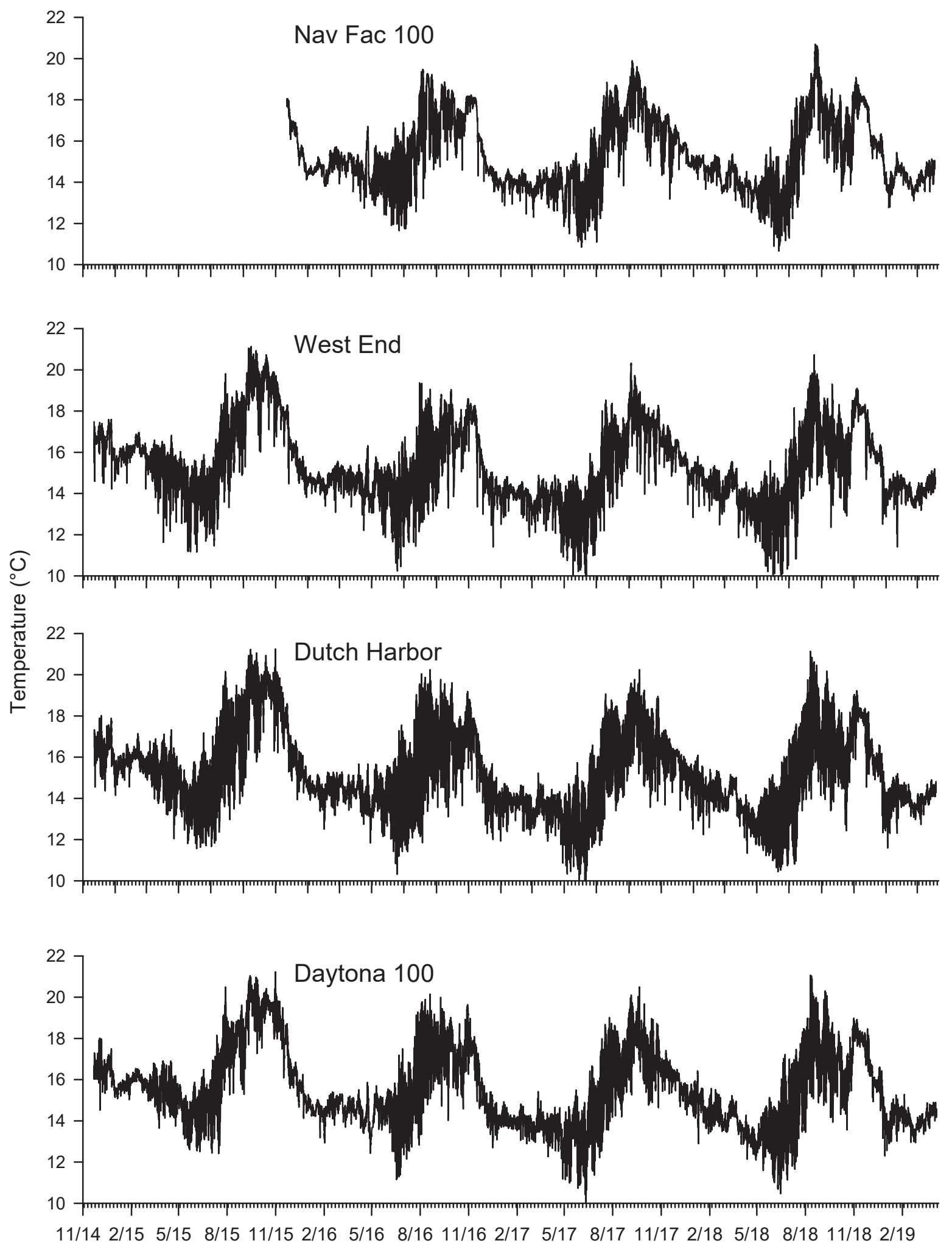

Month/year, November 2014-April 10, 2019

Figure 9. Hourly bottom temperature data for Nav Fac 100 from November 22, 2015, to April 10, 2019, and the other three supersites from November 22, 2014, to April 10, 2019. 


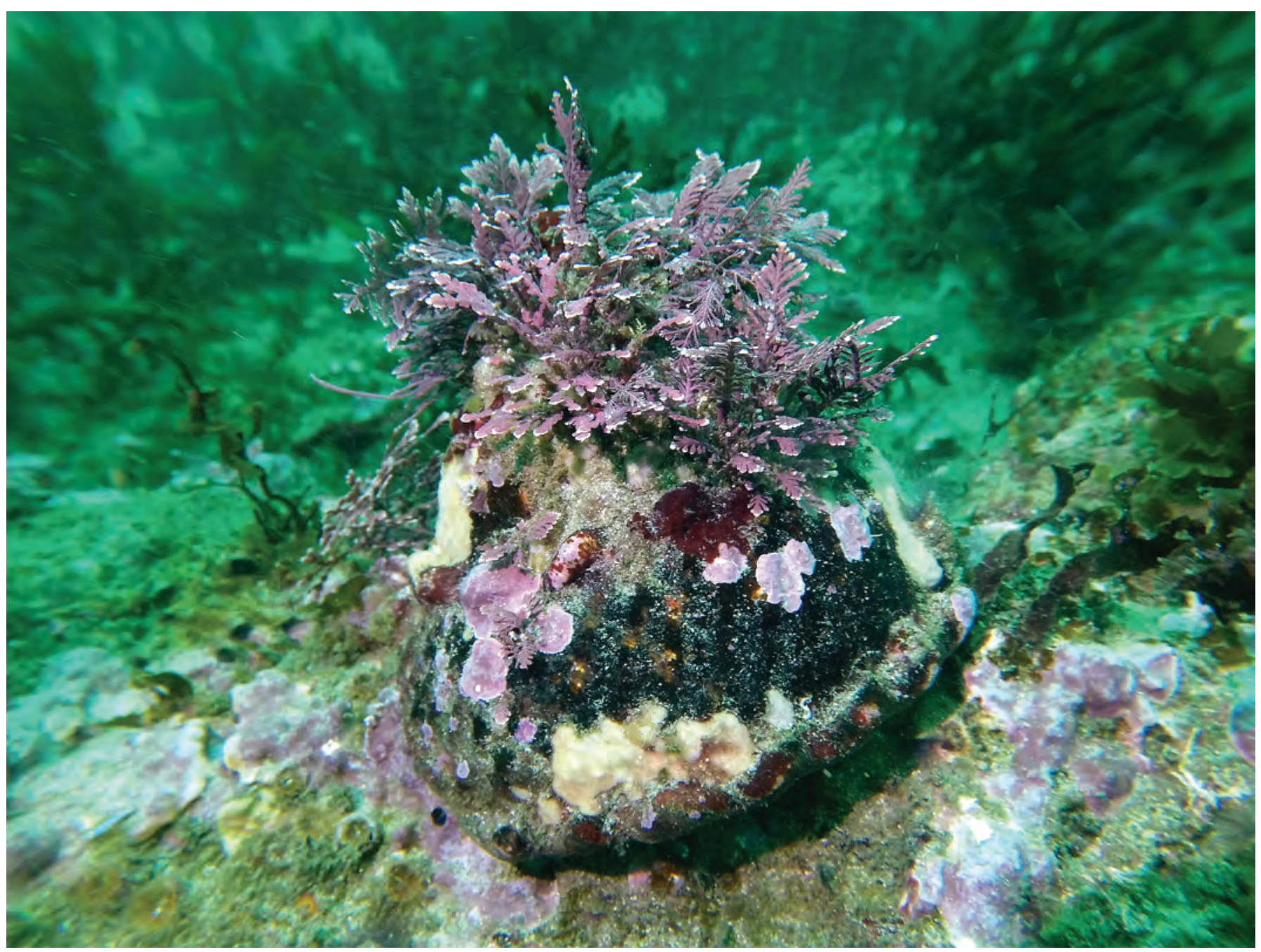

Figure 10. The wavy turban snail (Megastraea undosa) with typical shell fouling of erect and encrusting coralline algae, 0ctober 2018 (photograph by Zach Randell). Basal diameter is approximately 10 centimeters.

Sea star numbers were still very low, apparently as a result of sea star wasting syndrome (SSWS). Bat star (Patiria miniata) densities again increased very slightly, but the mean of the counts at the four supersites (1.6 per $20-\mathrm{m}^{2}$ swath) remained less than half the long-term mean since 1980 (3.5 per $20-\mathrm{m}^{2}$ swath). The giant sea star (Pisaster giganteus) was the only other asteroid counted again. Only 3 were counted on each of the trips in year 5, which was down from 10 counted in spring 2018. No sign of SSWS or sea star recruitment was observed.
During the two trips in year 5, divers estimated the sizes of 5,903 fish and counted 9,026. Both trips yielded higher total fish counts than those from year 4 but considerably less than in the previous few years. The fall 2018 total of 3,475 was less than the long-term average of 4,410 , but the spring 2019 count of 5,551 exceeded it. Table 6 shows minimum, maximum, and mean size and the number of fishes sized for each species pooled from all the sites in fall 2018, and table 7 shows these data for spring 2019. As usual, the schooling species, blacksmith (Chromis punctipinnis) and señorita (Oxyjulius californica), comprised most of these counts. 


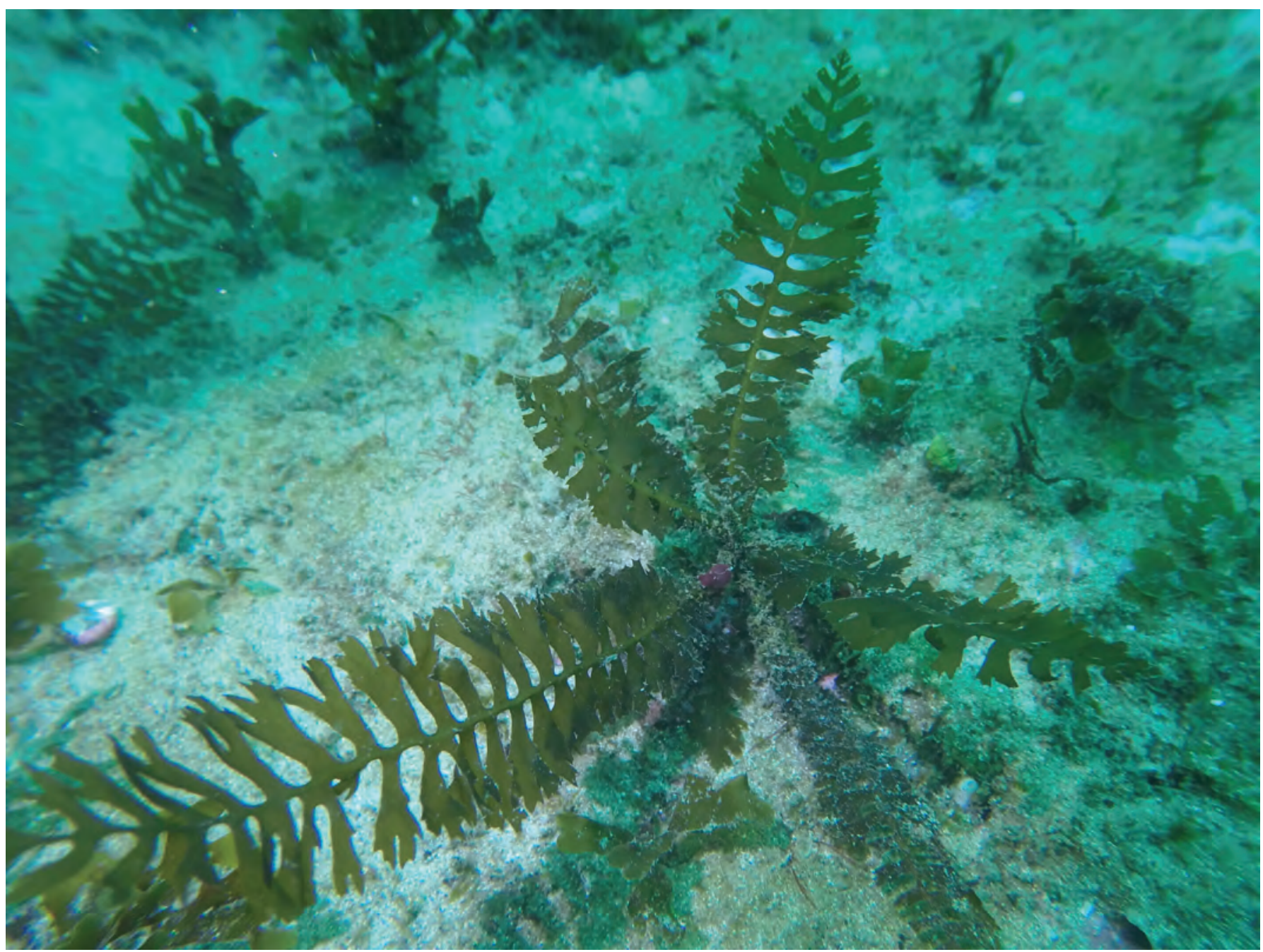

Figure 11. Juvenile form of the invasive alga Sargassum horneri, typical of plants seen in fall, at Nav Fac 100 supersite, 0 ctober 2018 (photograph by Zach Randell). Branch length is approximately 10-15 centimeters.

There was no recruitment of sheephead

(Semicossyphus pulcher) observed at the sites in year 5. An important predator on sea urchins, but targeted by sport anglers, sheephead typically only recruit to SNI during warm water years (Cowen, 1985). Estimated sizes of all sheephead from around the island during the 5-year period are plotted by sex in figure 12. This figure shows recruitment during the first few surveys when warm water (averaging $16.5^{\circ} \mathrm{C}$ and ranging above $21.0^{\circ} \mathrm{C}$ ) was prevalent. In fall 2018 and spring 2019, there were no individuals less than $14 \mathrm{~cm}$, and no juveniles were recorded. This is consistent with a return to cooler water conditions.

Kelp bass (Paralabrax clathratus) also recruited in fall 2014-fall 2015 (fig. 13). The size structure of the island-wide population has remained relatively stable throughout the last several sample years. In year 5 , there did appear to be more individuals in the larger size classes. 
Table 6. Summary of fall 2018 fish size estimates (total length, centimeters) for all sites combined.

[Schooling fish were typically recorded in size-bins and the midpoints of bins were used for these calculations. Abbreviations: f, female; m, male]

\begin{tabular}{|c|c|c|c|c|c|}
\hline Species name & Common names & $\begin{array}{l}\text { Minimum } \\
\text { size }\end{array}$ & $\begin{array}{l}\text { Maximum } \\
\text { size }\end{array}$ & $\begin{array}{l}\text { Mean } \\
\text { size }\end{array}$ & $\begin{array}{c}\text { Number } \\
\text { sized }\end{array}$ \\
\hline Artedius spp. & unidentified sculpin & 6 & 6 & 6.0 & 1 \\
\hline Atherinops affinis & topsmelt & 17.5 & 17.5 & 17.5 & 8 \\
\hline Brachyistius frenatus & kelp perch & 10 & 16 & 13.8 & 12 \\
\hline Caulolatilus princeps & ocean whitefish & 40 & 45 & 42.5 & 4 \\
\hline Chromis punctipinnis & blacksmith & 7.5 & 17.5 & 12.5 & 717 \\
\hline Rhinogobiops nicholsii & blackeye goby & 8 & 11 & 9.7 & 5 \\
\hline Embiotoca jacksoni & black perch & 10 & 35 & 19.4 & 54 \\
\hline Embiotoca lateralis & striped seaperch & 10 & 25 & 16.3 & 13 \\
\hline Gibbonsia spp. & kelpfish & 40 & 40 & 40.0 & 1 \\
\hline Girella nigricans & opaleye & 20 & 56 & 37.0 & 44 \\
\hline Heterostichus rostratus & giant kelpfish & 50 & 50 & 50.0 & 1 \\
\hline Hypsypops rubicundus & garibaldi & 12 & 35 & 23.1 & 16 \\
\hline Medialuna californiensis & halfmoon & 25 & 41 & 34.4 & 12 \\
\hline Myliobatis californica & bat ray & 100 & 100 & 100.0 & 1 \\
\hline Oxyjulis californica & senorita & 2.5 & 17.5 & 10.0 & 731 \\
\hline Oxylebius pictus & painted greenling & 9 & 25 & 13.6 & 26 \\
\hline Paralabrax clathratus & kelp bass & 10 & 52 & 33.7 & 71 \\
\hline Rhacochilus vacca & pile perch & 25 & 35 & 30.0 & 13 \\
\hline Sebastes atrovirens & kelp rockfish & 15 & 45 & 30.1 & 10 \\
\hline Sebastes caurinus & copper rockfish & 42 & 42 & 42.0 & 1 \\
\hline Sebastes mystinus & blue rockfish & 10 & 34 & 19.5 & 42 \\
\hline Sebastes serranoides & olive rockfish & 10 & 40 & 26.7 & 17 \\
\hline Semicossyphus pulcher (f) & California sheephead (f) & 15 & 67 & 38.0 & 98 \\
\hline Semicossyphus pulcher (m) & California sheephead (m) & 15 & 100 & 63.0 & 24 \\
\hline Total sized & - & - & - & - & 1,922 \\
\hline
\end{tabular}


Table 7. Summary of spring 2019 fish size estimates (total length, centimeters) for all sites combined.

[Schooling fish were typically recorded in size-bins and the midpoints of bins were used for these calculations. Abbreviations: f, female; $\mathrm{m}$, male]

\begin{tabular}{|c|c|c|c|c|c|}
\hline Species name & Common names & $\begin{array}{l}\text { Minimum } \\
\text { size }\end{array}$ & $\begin{array}{c}\text { Maximum } \\
\text { size }\end{array}$ & $\begin{array}{l}\text { Mean } \\
\text { size }\end{array}$ & $\begin{array}{c}\text { Number } \\
\text { sized }\end{array}$ \\
\hline Brachyistius frenatus & kelp perch & 10 & 15 & 12.3 & 6 \\
\hline Caulolatilus princeps & ocean whitefish & 34 & 60 & 45.2 & 7 \\
\hline Chromis punctipinnis & blacksmith & 7.5 & 17.5 & 12.5 & 2,258 \\
\hline Rhinogobiops nicholsii & blackeye goby & 6 & 12 & 9.3 & 8 \\
\hline Embiotoca jacksoni & black perch & 12 & 35 & 20.1 & 53 \\
\hline Embiotoca lateralis & striped seaperch & 11 & 25 & 17.4 & 15 \\
\hline Girella nigricans & opaleye & 25 & 53 & 42.0 & 13 \\
\hline Halichoeres semicinctus & rock wrasse & 15 & 15 & 15.0 & 1 \\
\hline Hypsurus caryi & rainbow seaperch & 14 & 20 & 16.8 & 4 \\
\hline Hypsypops rubicundus & garibaldi & 15 & 35 & 22.8 & 26 \\
\hline Medialuna californiensis & halfmoon & 19 & 38 & 27.7 & 12 \\
\hline Oxyjulis californica & senorita & 2.5 & 17.5 & 10.0 & 1,152 \\
\hline Oxylebius pictus & painted greenling & 9 & 25 & 13.6 & 20 \\
\hline Paralabrax clathratus & kelp bass & 7 & 70 & 33.0 & 85 \\
\hline Rhacochilus vacca & pile perch & 29 & 38 & 34.0 & 3 \\
\hline Sebastes atrovirens & kelp rockfish & 8 & 45 & 23.8 & 23 \\
\hline Sebastes chrysomelas & black and yellow rockfish & 21 & 35 & 28.0 & 2 \\
\hline Sebastes mystinus & blue rockfish & 10 & 37 & 21.8 & 95 \\
\hline Sebastes rastrelliger & grass rockfish & 35 & 35 & 35.0 & 1 \\
\hline Sebastes serranoides & olive rockfish & 16 & 52 & 35.8 & 23 \\
\hline Sebastes serriceps & treefish & 25 & 31 & 28.0 & 2 \\
\hline Semicossyphus pulcher (f) & California sheephead (f) & 14 & 60 & 33.2 & 141 \\
\hline Semicossyphus pulcher (m) & California sheephead (m) & 20 & 90 & 66.0 & 31 \\
\hline Total sized & - & - & - & - & 3,981 \\
\hline
\end{tabular}




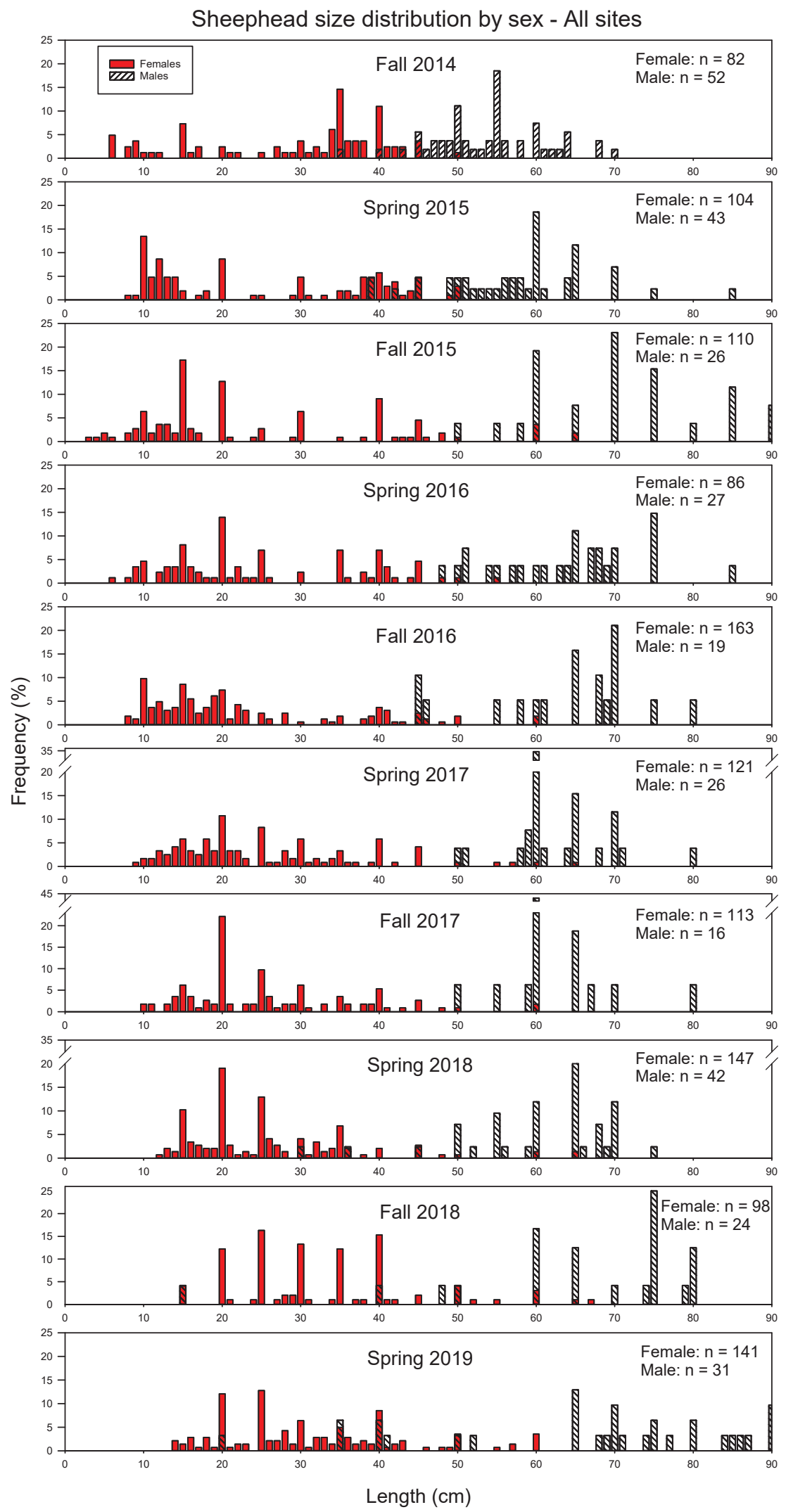

Figure 12. Size distribution by sex of sheephead (Semicossyphus pulcher) in fall 2014-spring 2019. [ $n=$ number of individuals] 
Kelp bass size distribution - All sites

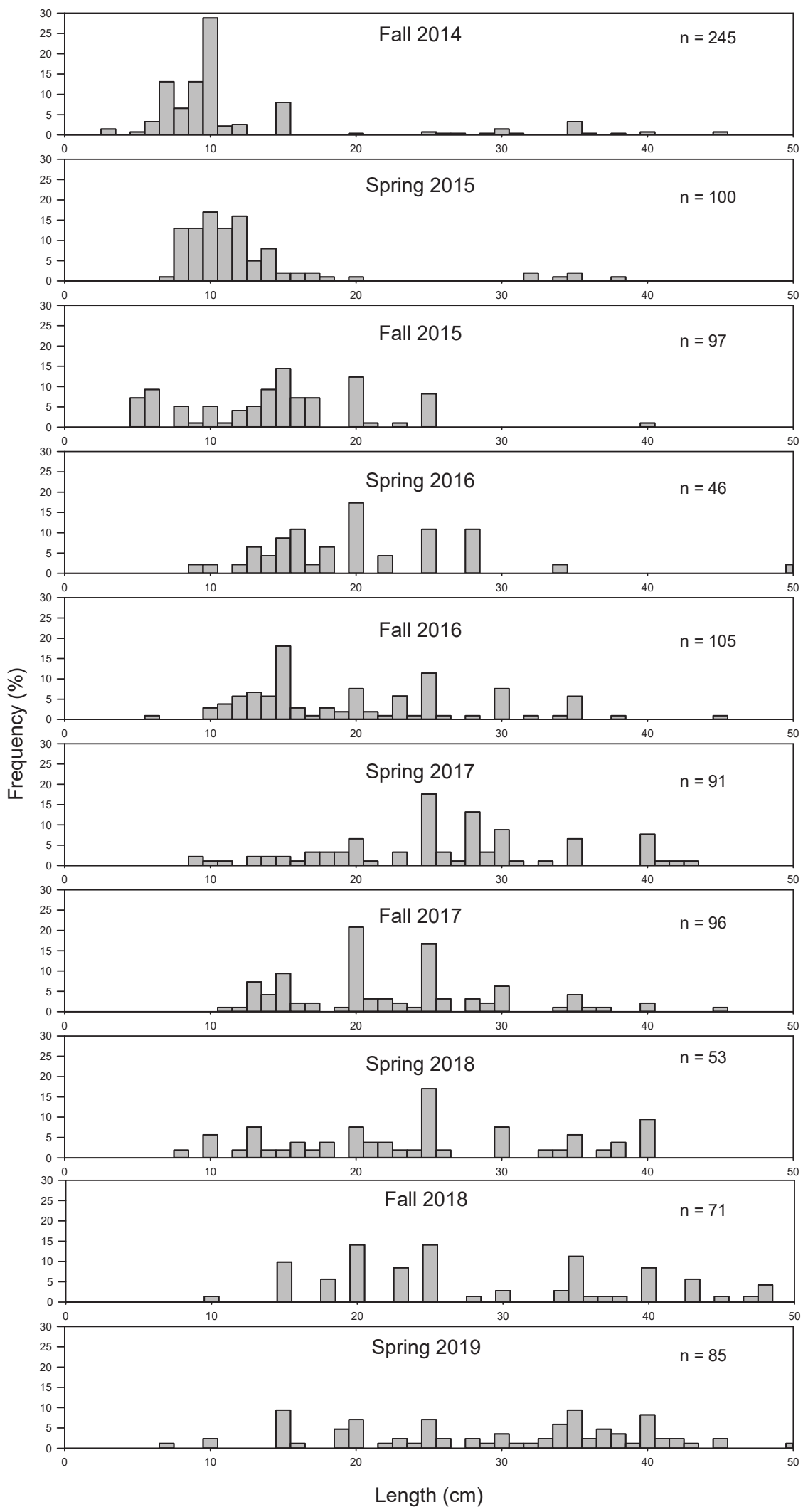

Figure 13. Size distribution of kelp bass (Paralabrax clathratus) in fall 2014-spring 2019. [ $\mathrm{n}=$ number of individuals] 


\section{Nav Fac 100}

After nearly 25 years of urchin overgrazing, Nav Fac 100 continued to change following its release from an urchin dominated state. Figure 14 shows counts during the last 5 years of some of the most dynamic species recorded on the swaths. Purple urchin (S. purpuratus) numbers declined substantially in 2015 but increased somewhat in 2018. Counts were lower in year 5 than in spring 2018 but were still two to three times higher than in 2016 and 2017, and they remained the second most common swath-counted organism. Nav Fac 100 has been supporting more macroalgae in recent years. The most abundant species counted on swaths (for the seventh time in a row) was $C$. osmundacea, whose numbers reached all-time highs. Pterygophora californica counts also increased in year 5. Spring counts of the invasive algae, S. horneri, were similarly high in 2017 and 2018 but were much lower in 2019. The cause of this reduction is unclear. Fall counts of the alga in 2018 were similar to the previous two fall seasons. Counts of the wavy turban snail (M. undosa) were again markedly higher this year making it the third most common of the swath-counted organisms. Table 8 shows the mean and standard deviation of swath counted organisms for this supersite in fall 2014 through spring 2019.

Macrocystis pyrifera densities were low on the supersite in year 5. Figures 15 and 16 show the number of stipes and the holdfast diameters of each $M$. pyrifera counted on the Nav Fac 100 permanent swaths for the last 10 sampling periods. Both metrics indicated there was poor survival and very little recruitment apparent between fall 2017 and spring 2018 and very little the following year so that by spring 2019 there were only $3 \mathrm{M}$. pyrifera greater than $1 \mathrm{~m}$ tall on the 10 supersite swaths.

A summary of the invertebrate sizes measured on swaths during the last 10 sampling trips is presented in table 9. Most of these species were not common enough to result in useful numbers of measurements. Two of the species, Kellet's whelk (Kelletia kelletii) and the wavy turban snail (M. undosa), were sufficiently numerous for analysis, however. There were only three Kelletia counted on the site in fall 2014, but then the number increased to 41 in fall 2015 before falling back to low levels again the next spring. Counts remained low until the last three sampling periods, when numbers again rose. An examination of their size structure revealed that these were likely recruitment events (fig. 17). Mobility and relatively low numbers contribute to our uncertainty concerning the fate of the 2015 recruits. Slow growth rates in this species (Cumberland, 1995) suggest that the size mode centered around 40 millimeters ( $\mathrm{mm}$ ) in the spring 2019 sample likely represents the same cohort which appeared in the spring 2018 sample.

Densities of $M$. undosa, which have continued to increase at Nav Fac 100 since urchins declined there, more than doubled between spring and fall 2017. Counts of M. undosa were down somewhat in spring 2018 but were substantially higher in year 5. The size structure of these snails (fig. 18) indicated that most of the recent increase was likely a result of movement rather than recruitment of young. The majority of the population (96 percent) was between 25 and $80 \mathrm{~mm}$ in shell length. Based on growth rates from tagging studies conducted in Baja California, (Martone and Micheli, 2012), these snails were likely between 1 and 5 years of age- but perhaps somewhat older, owing to slower growth as a result of colder water temperatures at SNI.

Most of the sea urchin size data we have collected does not resolve into easily identifiable cohorts, perhaps because of variation in growth rates or mortality. In order to more easily identify changes in the size structure over time or differences among sites, we have summarized these data for purple and red sea urchins by calculating the percent of each sample in three size bins: one representing recruits up to 1 year of age, one representing the largest individuals, and one size bin in between. Sea urchin growth is variable depending on food quality and availability as well as physical factors such as spine damage (Ebert, 1968; Kenner, 1992), but a reasonable approximation of first year's growth potential in southern California is $25 \mathrm{~mm}$ for $S$. purpuratus (Ebert, 1977; Russell, 1987 ) and $35 \mathrm{~mm}$ for $S$. franciscanus (Tegner and Dayton, 1991; Ebert and Russell, 1992). The largest size bin was chosen to represent the oldest urchins and consists, arbitrarily, of the largest 15 percent of each species from the pooled data from all sites and 5 years of collections. The middle size bin may represent several cohorts depending on growth. For purple urchins, these size bins are less than or equal to $25 \mathrm{~mm}$, 26-40 mm, and greater than $40 \mathrm{~mm}$ (table 10), and for red urchins, they are less than or equal to $35 \mathrm{~mm}, 36-75 \mathrm{~mm}$, and greater than $75 \mathrm{~mm}$ (table 11).

Purple sea urchin size distribution at Nav Fac 100 showed little change in the last 2 years. The size distribution has not shown any sign of a large recruitment event since 2014 (fig. 19). There were, however, a few individuals less than or equal to $10 \mathrm{~mm}$ in diameter, which indicated some recruitment in all sampling periods. Although an effort was made to include small individuals in size samples at the rate they were encountered, this size class was likely under sampled. Small urchins often take refuge in holdfasts and under rocks, algae, or other invertebrates making any non-destructive sampling methodology biased against them. Although the portion of purple urchins in the smallest size bin had declined from the time of the 2014 recruitment, it was close to 50 percent in the most recent three samples (table 10). The high proportion of urchins in the smallest size bin, combined with the low proportion in the largest size bin, made the size distribution most similar to Daytona 100.

Strongylocentrotus franciscanus declined slightly from year 4 levels, returning to densities similar to those recorded in 2016 and 2017. Their size distribution continued a trend of losing smaller and larger individuals until in spring 2019; 98 percent of the sample was between 35 and $100 \mathrm{~mm}$ in test diameter (fig. 20). In year 5, this supersite had the fewest red urchins in the smallest size bin but retained the most in the largest size bin (table 11). 


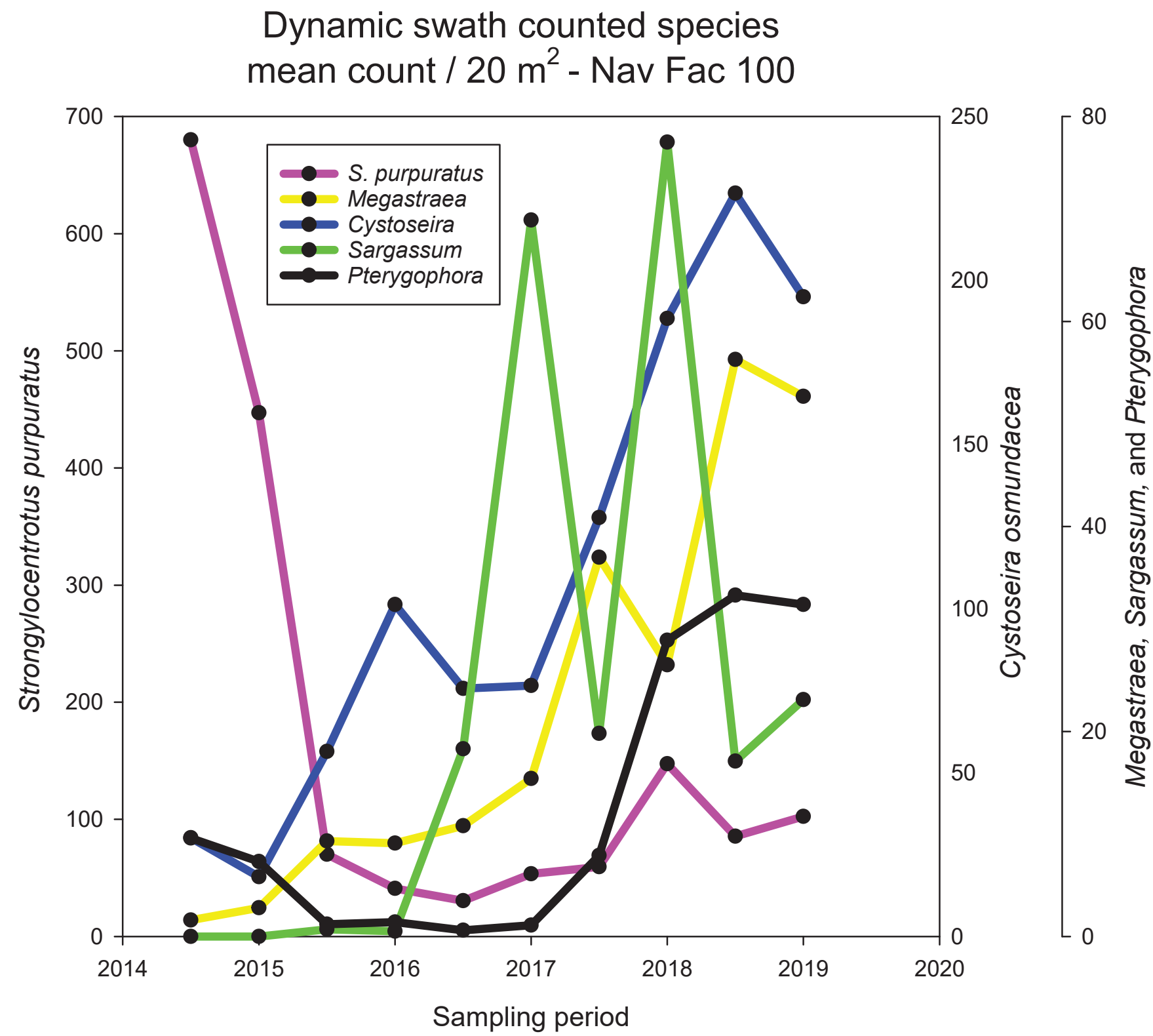

Figure 14. Mean densities of some swath-counted species that have demonstrated changing abundance at Nav Fac 100 during the last 5 years. [Note three vertical axes for densities of different species groups]

Table 8. Nav Fac 100 mean (standard deviation) swath counts for fall 2014 through spring 2019 expressed as individuals per 20-square meter transect.

[>, greater than; $\mathrm{m}$, meter; $<$, less than]

\begin{tabular}{|c|c|c|c|c|c|c|c|c|c|c|}
\hline Species name & Fall 2014 & $\begin{array}{c}\text { Spring } \\
2015\end{array}$ & Fall 2015 & $\begin{array}{c}\text { Spring } \\
2016\end{array}$ & Fall 2016 & $\begin{array}{c}\text { Spring } \\
2017\end{array}$ & Fall 2017 & $\begin{array}{c}\text { Spring } \\
2018\end{array}$ & Fall 2018 & $\begin{array}{c}\text { Spring } \\
2019\end{array}$ \\
\hline $\begin{array}{l}\text { Aplysia } \\
\quad \text { californica }\end{array}$ & $\begin{array}{c}0.3 \\
(0.48)\end{array}$ & $\begin{array}{c}2.4 \\
(2.41)\end{array}$ & $\begin{array}{c}0 \\
(0.00)\end{array}$ & $\begin{array}{c}0.8 \\
(1.03)\end{array}$ & $\begin{array}{c}1.3 \\
(2.26)\end{array}$ & $\begin{array}{c}0 \\
(0.00)\end{array}$ & $\begin{array}{c}0.7 \\
(1.64)\end{array}$ & $\begin{array}{c}0 \\
(0.00)\end{array}$ & $\begin{array}{c}0 \\
(0.00)\end{array}$ & $\begin{array}{c}0 \\
(0.00)\end{array}$ \\
\hline $\begin{array}{l}\text { Astrometis } \\
\quad \text { sertulifera }\end{array}$ & $\begin{array}{c}0 \\
(0.00)\end{array}$ & $\begin{array}{c}0 \\
(0.00)\end{array}$ & $\begin{array}{c}0 \\
(0.00)\end{array}$ & $\begin{array}{c}0 \\
(0.00)\end{array}$ & $\begin{array}{c}0 \\
(0.00)\end{array}$ & $\begin{array}{c}0 \\
(0.00)\end{array}$ & $\begin{array}{c}0 \\
(0.00)\end{array}$ & $\begin{array}{c}0 \\
(0.00)\end{array}$ & $\begin{array}{c}0 \\
(0.00)\end{array}$ & $\begin{array}{c}0 \\
(0.00)\end{array}$ \\
\hline $\begin{array}{c}\text { Crassadoma } \\
\text { gigantea }\end{array}$ & $\begin{array}{c}0 \\
(0.00)\end{array}$ & $\begin{array}{c}0 \\
(0.00)\end{array}$ & $\begin{array}{c}0.6 \\
(1.07)\end{array}$ & $\begin{array}{c}0 \\
(0.00)\end{array}$ & $\begin{array}{c}0.1 \\
(0.32)\end{array}$ & $\begin{array}{c}0.3 \\
(0.67)\end{array}$ & $\begin{array}{c}0.3 \\
(0.95)\end{array}$ & $\begin{array}{c}0.5 \\
(0.85)\end{array}$ & $\begin{array}{c}0.3 \\
(0.48)\end{array}$ & $\begin{array}{c}0.3 \\
(0.67)\end{array}$ \\
\hline
\end{tabular}


Table 8. Nav Fac 100 mean (standard deviation) swath counts for fall 2014 through spring 2019 expressed as individuals per 20-square meter transect.-Continued

[>, greater than; m, meter; <, less than]

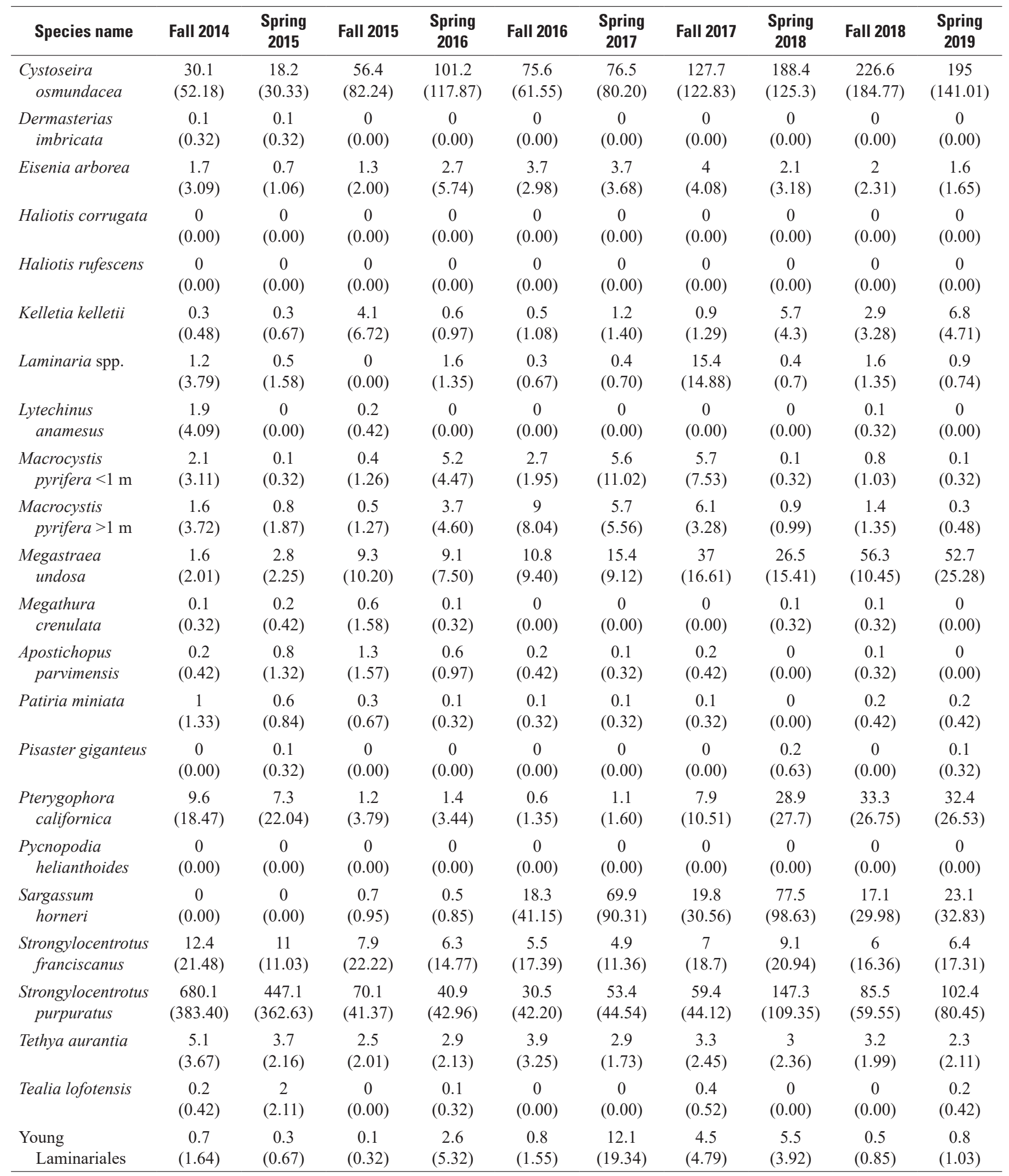


Macrocystis pyrifera stipe counts - Nav Fac 100

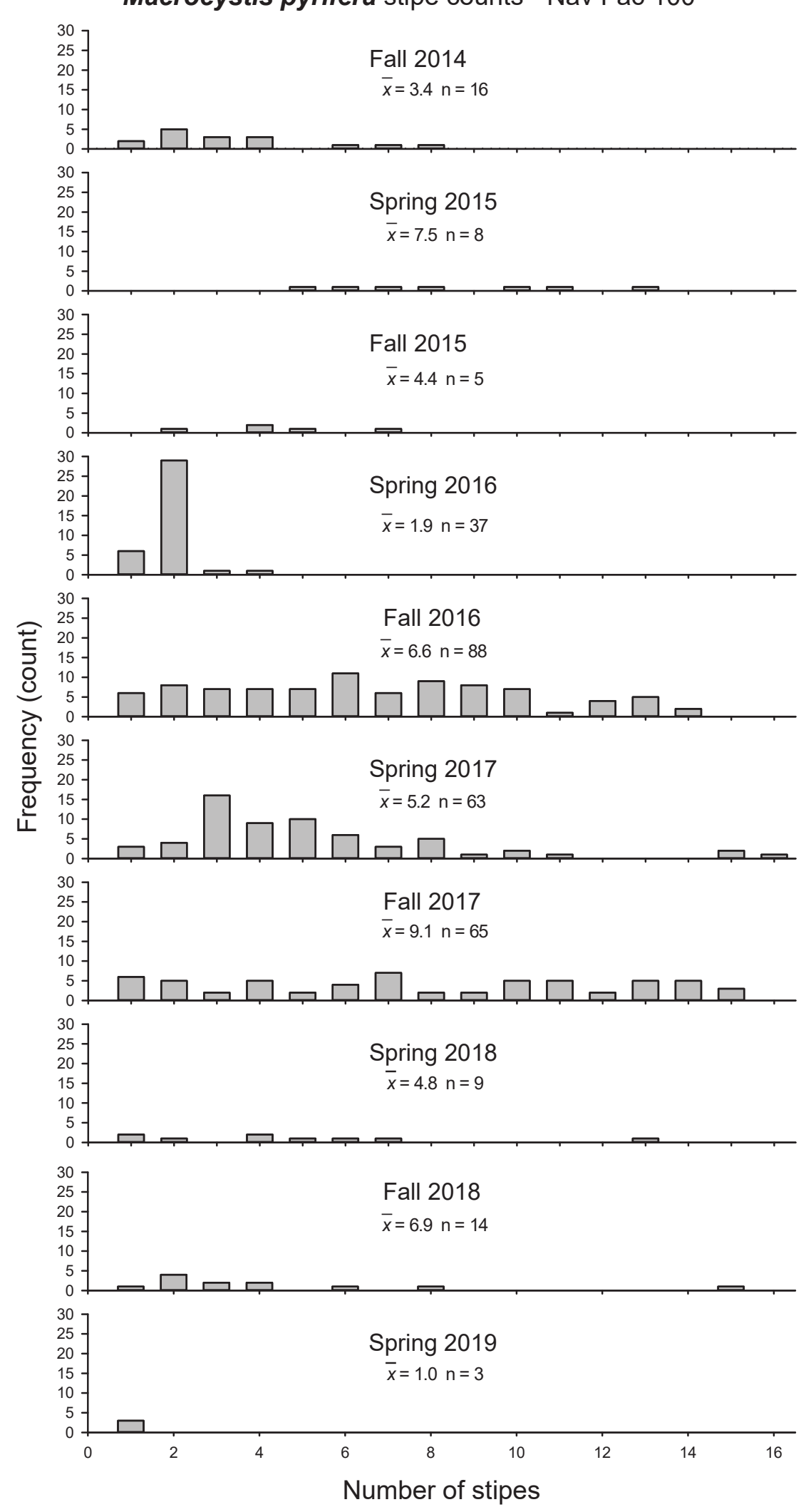

Figure 15. Nav Fac 100 Macrocystis pyrifera greater than 1-meter (m) tall stipe counts by season (fall 2014-spring 2019). [ $\bar{X}$ is mean count, $\mathrm{n}$ is number of individuals] 

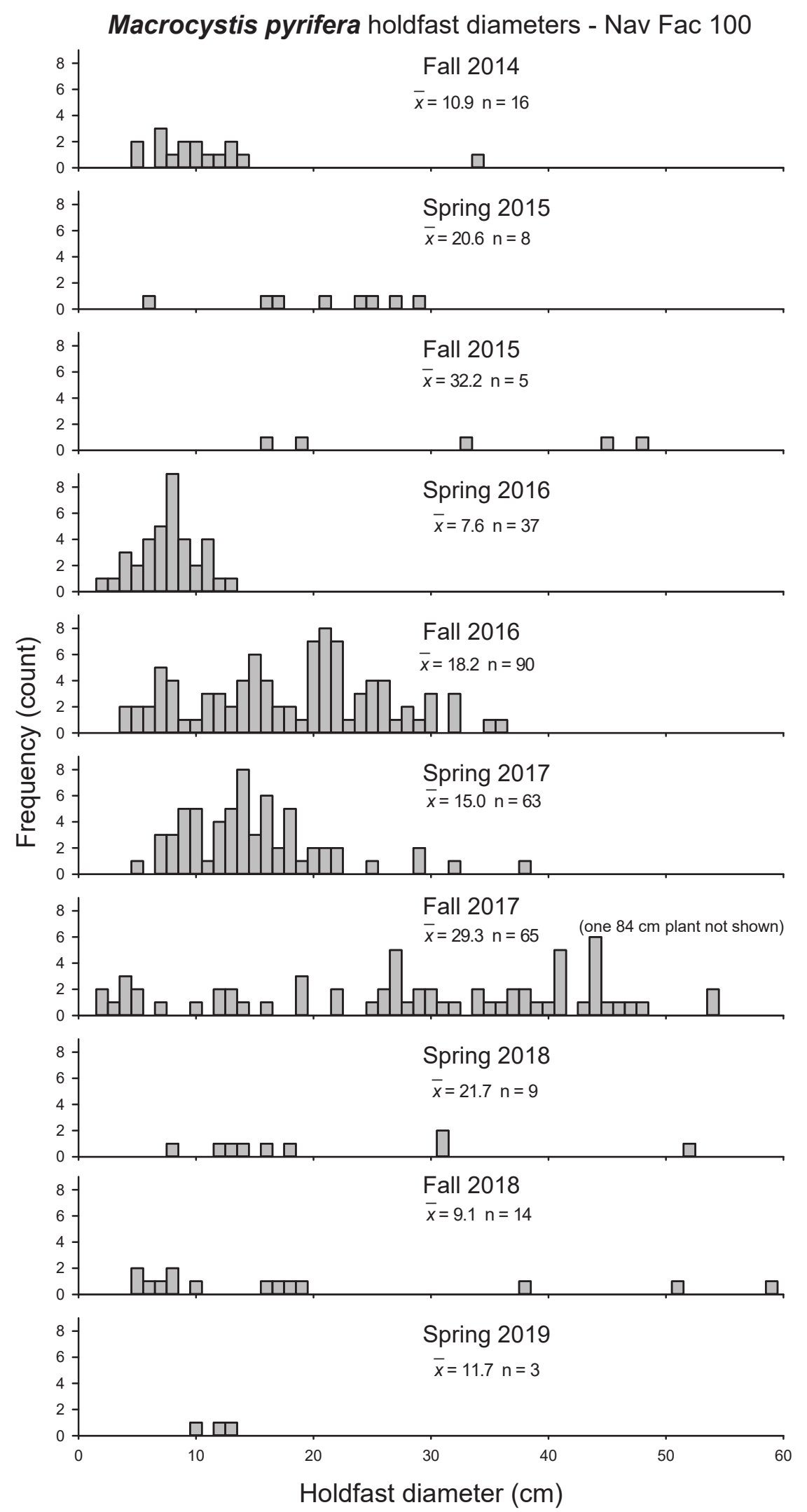

Figure 16. Nav Fac 100 Macrocystis pyrifera greater than 1-meter (m) tall holdfast diameters by season (fall 2014-spring 2019). [ $\bar{x}$ is mean count, $\mathrm{n}$ is number of individuals] 
Table 9. Sizes of invertebrates measured on swaths at Nav Fac 100, fall 2014 through spring 2019.

[Strongylocentrotus spp. excluded. See figures 19 and 20 for purple and red urchin size data. Abbreviations: N, sample size; Min, minimum; - , no data; Max, maximum]

\begin{tabular}{|c|c|c|c|c|c|c|c|c|}
\hline \multirow[b]{2}{*}{ Size } & \multicolumn{8}{|c|}{ Species name } \\
\hline & $\begin{array}{c}\text { Crassadoma } \\
\text { gigantea }\end{array}$ & $\begin{array}{c}\text { Dermasterias } \\
\text { imbricata }\end{array}$ & $\begin{array}{r}\text { Kelletia } \\
\text { kelletii }\end{array}$ & $\begin{array}{l}\text { Lytechinus } \\
\text { anamesus }\end{array}$ & $\begin{array}{c}\text { Megastraea } \\
\text { undosa }\end{array}$ & $\begin{array}{c}\text { Megathura } \\
\text { crenulata }\end{array}$ & $\begin{array}{l}\text { Patiria } \\
\text { miniata }\end{array}$ & $\begin{array}{l}\text { Pisaster } \\
\text { giganteus }\end{array}$ \\
\hline \multicolumn{9}{|c|}{ Year 1: Fall 2014} \\
\hline $\mathrm{N}$ & 0 & 1 & 3 & 0 & 16 & 1 & 11 & 0 \\
\hline Min & - & 80 & 30 & - & 15 & 52 & 60 & - \\
\hline Max & - & 80 & 130 & - & 100 & 52 & 109 & - \\
\hline Mean & - & 80.0 & 63.3 & - & 54.7 & 52.0 & 74.5 & - \\
\hline \multicolumn{9}{|c|}{ Year 1: Spring 2015} \\
\hline $\mathrm{N}$ & 0 & 1 & 4 & 0 & 28 & 2 & 6 & 1 \\
\hline Min & - & 52 & 103 & - & 22 & 100 & 60 & 180 \\
\hline Max & - & 52 & 150 & - & 170 & 180 & 90 & 180 \\
\hline Mean & - & 52.0 & 123.5 & - & 83.1 & 140.0 & 70.0 & 180.0 \\
\hline \multicolumn{9}{|c|}{ Year 2: Fall 2015} \\
\hline $\mathrm{N}$ & 6 & 0 & 41 & 2 & 98 & 1 & 3 & 0 \\
\hline Min & 19 & - & 6 & 8 & 14 & 112 & 60 & - \\
\hline Max & 130 & - & 55 & 13 & 130 & 112 & 72 & - \\
\hline Mean & 57.2 & - & 28.0 & 10.5 & 55.3 & 112.0 & 64.7 & - \\
\hline \multicolumn{9}{|c|}{ Year 2: Spring 2016} \\
\hline $\mathrm{N}$ & 0 & 0 & 6 & 0 & 92 & 1 & 1 & 0 \\
\hline Min & - & - & 20 & - & 18 & 72 & 30 & - \\
\hline Max & - & - & 40 & - & 115 & 72 & 30 & - \\
\hline Mean & - & - & 31.7 & - & 52.9 & 72.0 & 30.0 & - \\
\hline \multicolumn{9}{|c|}{ Year 3: Fall 2016} \\
\hline $\mathrm{N}$ & 1 & 0 & 5 & 0 & 108 & 0 & 1 & 0 \\
\hline Min & 77 & - & 40 & - & 18 & - & 120 & - \\
\hline Max & 77 & - & 124 & - & 108 & - & 120 & - \\
\hline Mean & 77.0 & - & 59.4 & - & 47.8 & - & 120.0 & - \\
\hline \multicolumn{9}{|c|}{ Year 3: Spring 2017} \\
\hline $\mathrm{N}$ & 4 & 0 & 12 & 0 & 155 & 0 & 1 & 0 \\
\hline Min & 55 & - & 11 & - & 15 & - & 27 & - \\
\hline Max & 60 & - & 130 & - & 101 & - & 27 & - \\
\hline Mean & 58.3 & - & 57.9 & - & 50.1 & - & 27.0 & - \\
\hline \multicolumn{9}{|c|}{ Year 4: Fall 2017} \\
\hline $\mathrm{N}$ & 3 & 0 & 9 & 0 & 370 & 0 & 1 & 0 \\
\hline Min & 48 & - & 32 & - & 26 & - & 70 & - \\
\hline Max & 70 & - & 138 & - & 114 & - & 70 & - \\
\hline Mean & 58.0 & - & 68.0 & - & 54.3 & - & 70.0 & - \\
\hline \multicolumn{9}{|c|}{ Year 4: Spring 2018} \\
\hline $\mathrm{N}$ & 5 & 0 & 57 & 0 & 265 & 1 & 0 & 2 \\
\hline Min & 42 & - & 18 & - & 22 & 51 & - & 70 \\
\hline Max & 75 & - & 135 & - & 99 & 51 & - & 80 \\
\hline Mean & 57.6 & - & 58.5 & - & 52.0 & 51.0 & - & 75.0 \\
\hline
\end{tabular}


Table 9. Sizes of invertebrates measured on swaths at Nav Fac 100, fall 2014 through spring 2019.Continued

[Strongylocentrotus spp. excluded. See figures 19 and 20 for purple and red urchin size data. Abbreviations: N, sample size; Min, minimum; - , no data; Max, maximum]

\begin{tabular}{|c|c|c|c|c|c|c|c|c|}
\hline \multirow[b]{2}{*}{ Size } & \multicolumn{8}{|c|}{ Species name } \\
\hline & $\begin{array}{c}\text { Crassadoma } \\
\text { gigantea }\end{array}$ & $\begin{array}{c}\text { Dermasterias } \\
\text { imbricata }\end{array}$ & $\begin{array}{r}\text { Kelletia } \\
\text { kelletii }\end{array}$ & $\begin{array}{l}\text { Lytechinus } \\
\text { anamesus }\end{array}$ & $\begin{array}{c}\text { Megastraea } \\
\text { undosa }\end{array}$ & $\begin{array}{c}\text { Megathura } \\
\text { crenulata }\end{array}$ & $\begin{array}{c}\text { Patiria } \\
\text { miniata }\end{array}$ & $\begin{array}{c}\text { Pisaster } \\
\text { giganteus }\end{array}$ \\
\hline \multicolumn{9}{|c|}{ Year 5: Fall 2018} \\
\hline $\mathrm{N}$ & 3 & 0 & 29 & 0 & 563 & 1 & 2 & 0 \\
\hline Min & 43 & - & 32 & - & 19 & 110 & 64 & - \\
\hline Max & 84 & - & 112 & - & 97 & 110 & 75 & - \\
\hline Mean & 61.7 & - & 70.7 & - & 53.2 & 110.0 & 69.5 & - \\
\hline \multicolumn{9}{|c|}{ Year 5: Spring 2019} \\
\hline $\mathrm{N}$ & 3 & 0 & 64 & 0 & 528 & 0 & 2 & 1 \\
\hline Min & 48 & - & 24 & - & 19 & - & 61 & 104 \\
\hline $\operatorname{Max}$ & 71 & - & 153 & - & 121 & - & 81 & 104 \\
\hline Mean & 57.0 & - & 59.2 & - & 51.6 & 一 & 71.0 & 104.0 \\
\hline
\end{tabular}



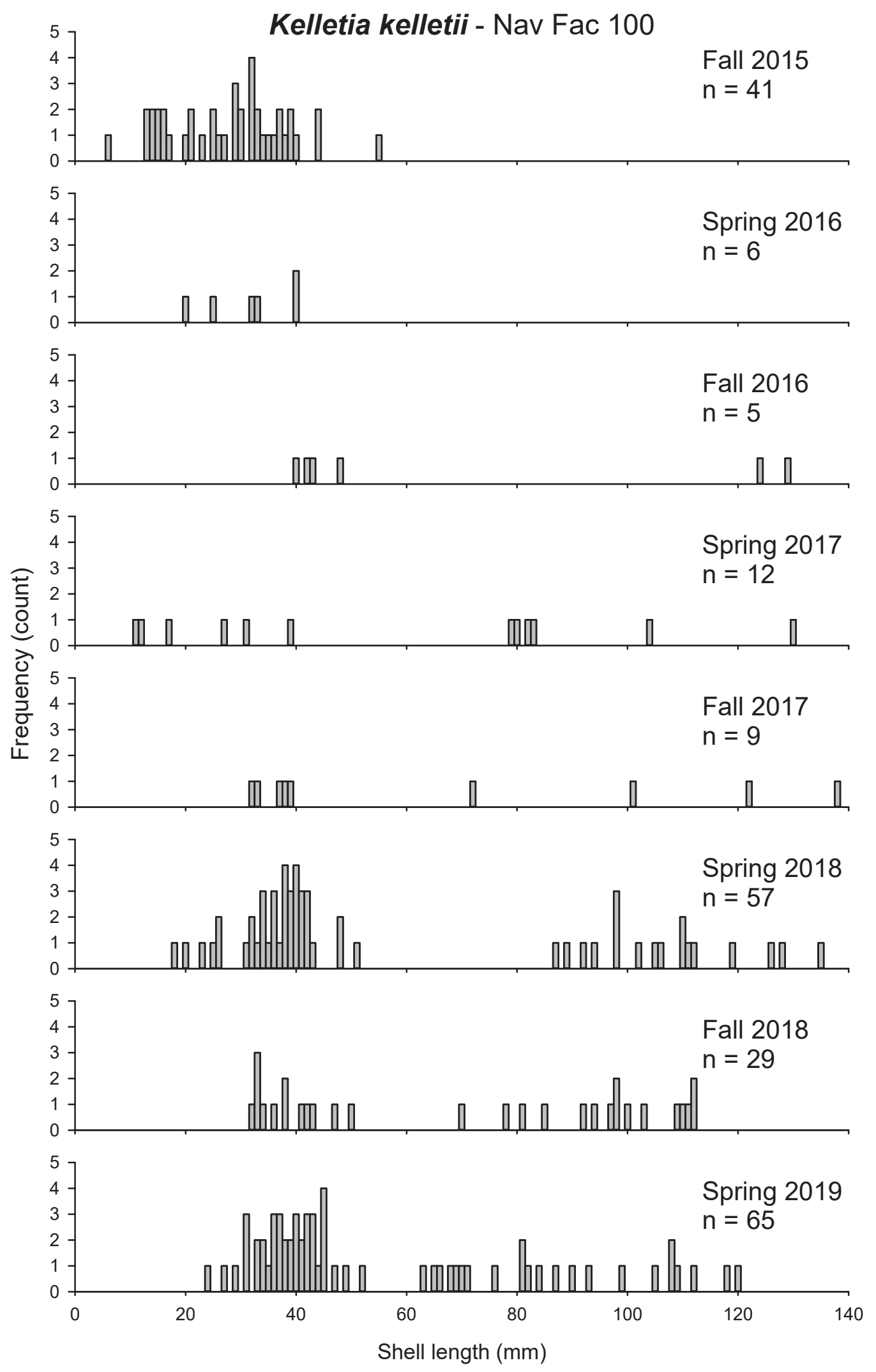

Figure 17. Size structure of Kellet's whelk (Kelletia kelletii) at Nav Fac 100 in fall 2014-spring 2019. [n = number of individuals] 
Megastraea undosa - Nav Fac 100
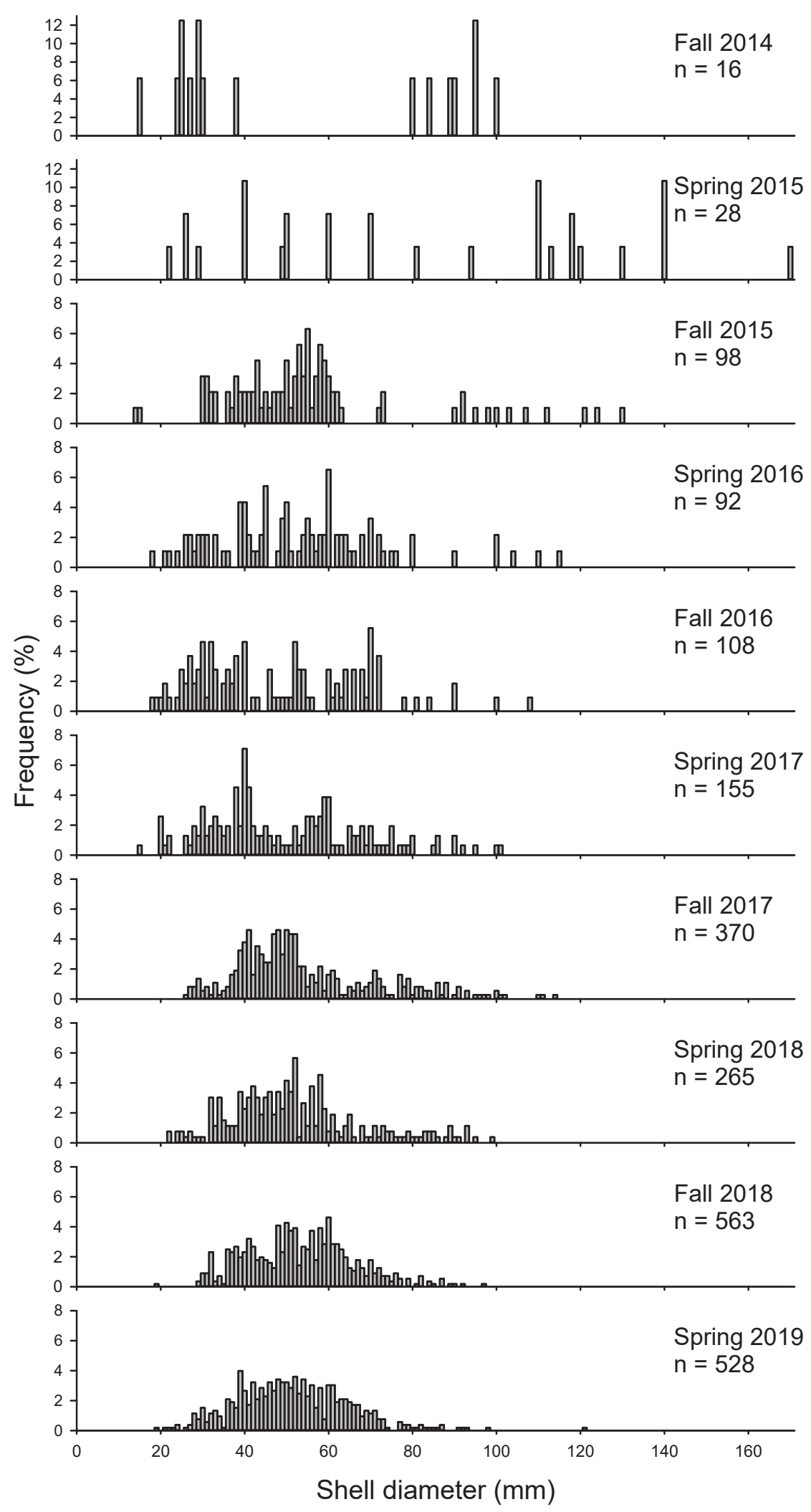

Figure 18. Nav Fac 100 size structure of wavy turban snails (Megastraea undosa) in fall 2014-spring 2019. [Note different frequency scales, $\mathrm{n}=$ number of individuals] 
Table 10. Percentage of Strongylocentrotus purpuratus in three size bins at each supersite in fall 2014-spring 2019.

$[\leq$, less than or equal to; >, greater than]

\begin{tabular}{|c|c|c|c|c|c|c|c|c|c|c|}
\hline \multicolumn{11}{|c|}{ Sample } \\
\hline $\begin{array}{l}\text { Size } \\
\text { class }\end{array}$ & $\begin{array}{l}\text { Fall } \\
2014\end{array}$ & $\begin{array}{c}\text { Spring } \\
2015\end{array}$ & $\begin{array}{l}\text { Fall } \\
2015\end{array}$ & $\begin{array}{c}\text { Spring } \\
2016\end{array}$ & $\begin{array}{l}\text { Fall } \\
2016\end{array}$ & $\begin{array}{c}\text { Spring } \\
2017\end{array}$ & $\begin{array}{l}\text { Fall } \\
2017\end{array}$ & $\begin{array}{c}\text { Spring } \\
2018\end{array}$ & $\begin{array}{l}\text { Fall } \\
2018\end{array}$ & $\begin{array}{c}\text { Spring } \\
2019\end{array}$ \\
\hline \multicolumn{11}{|c|}{ Nav Fac 100} \\
\hline$\leq 25$ & 85.7 & 91.0 & 65.9 & 30.1 & 24.8 & 52.7 & 34.0 & 50.4 & 48.5 & 47.5 \\
\hline $26-40$ & 13.8 & 9.0 & 28.3 & 65.7 & 63.1 & 44.1 & 52.4 & 37.7 & 44.1 & 41.5 \\
\hline$>40$ & 0.5 & 0.0 & 5.8 & 4.2 & 12.1 & 3.2 & 13.7 & 11.9 & 7.4 & 11.0 \\
\hline \multicolumn{11}{|c|}{ West End } \\
\hline$\leq 25$ & 29.3 & 10.8 & 25.0 & 28.8 & 33.3 & 35.6 & 21.7 & 32.6 & 41.7 & 32.4 \\
\hline $26-40$ & 38.9 & 47.5 & 53.2 & 49.8 & 57.7 & 53.2 & 56.7 & 52.7 & 47.6 & 48.5 \\
\hline$>40$ & 31.7 & 41.7 & 21.8 & 21.5 & 9.0 & 11.2 & 21.7 & 14.7 & 10.7 & 19.1 \\
\hline \multicolumn{11}{|c|}{ Dutch Harbor } \\
\hline$\leq 25$ & 34.3 & 18.5 & 25.5 & 16.0 & 14.0 & 30.6 & 25.5 & 32.9 & 27.2 & 26.6 \\
\hline $26-40$ & 35.9 & 52.7 & 47.7 & 42.3 & 52.4 & 55.3 & 48.9 & 45.9 & 53.0 & 49.8 \\
\hline$>40$ & 29.8 & 28.8 & 26.8 & 41.8 & 33.6 & 14.2 & 25.5 & 21.2 & 19.8 & 23.7 \\
\hline \multicolumn{11}{|c|}{ Daytona 100} \\
\hline$\leq 25$ & 65.3 & 39.5 & 55.1 & 31.1 & 39.7 & 42.9 & 45.0 & 40.1 & 49.5 & 46.5 \\
\hline $26-40$ & 34.7 & 56.0 & 42.4 & 65.8 & 57.4 & 52.2 & 52.0 & 57.2 & 47.1 & 43.3 \\
\hline$>40$ & 0.0 & 4.5 & 2.4 & 3.2 & 2.9 & 4.9 & 3.0 & 2.8 & 3.3 & 10.1 \\
\hline
\end{tabular}

Table 11. Percentage of Strongylocentrotus franciscanus in three size bins at each supersite in fall 2014-spring 2019.

$[\leq$, less than or equal to; >, greater than]

\begin{tabular}{|c|c|c|c|c|c|c|c|c|c|c|}
\hline $\begin{array}{l}\text { Size } \\
\text { class }\end{array}$ & $\begin{array}{l}\text { Fall } \\
2014\end{array}$ & $\begin{array}{c}\text { Spring } \\
2015\end{array}$ & $\begin{array}{l}\text { Fall } \\
2015\end{array}$ & $\begin{array}{c}\text { Spring } \\
2016\end{array}$ & $\begin{array}{l}\text { Fall } \\
2016\end{array}$ & $\begin{array}{c}\text { Spring } \\
2017\end{array}$ & $\begin{array}{l}\text { Fall } \\
2017\end{array}$ & $\begin{array}{c}\text { Spring } \\
2018\end{array}$ & $\begin{array}{l}\text { Fall } \\
2018\end{array}$ & $\begin{array}{c}\text { Spring } \\
2019\end{array}$ \\
\hline \multicolumn{11}{|c|}{ Nav Fac 100} \\
\hline$\leq 35$ & 21.5 & 23.7 & 36.3 & 3.4 & 3.8 & 7.7 & 5.4 & 7.4 & 4.4 & 2.9 \\
\hline $35-75$ & 49.3 & 41.4 & 37.2 & 33.9 & 42.7 & 63.6 & 57.4 & 60.7 & 81.5 & 78.5 \\
\hline$>75$ & 29.2 & 34.8 & 26.5 & 62.6 & 53.5 & 28.7 & 37.3 & 31.9 & 14.1 & 18.5 \\
\hline \multicolumn{11}{|c|}{ West End } \\
\hline$\leq 35$ & 20.7 & 3.0 & 22.9 & 15.3 & 17.6 & 17.9 & 13.4 & 21.1 & 14.1 & 18.8 \\
\hline $35-75$ & 63.7 & 84.7 & 73.5 & 84.3 & 79.6 & 80.9 & 85.9 & 77.9 & 84.8 & 80.7 \\
\hline$>75$ & 15.6 & 12.4 & 3.6 & 0.4 & 2.8 & 1.2 & 0.7 & 1.0 & 1.2 & 0.5 \\
\hline \multicolumn{11}{|c|}{ Dutch Harbor } \\
\hline$\leq 35$ & 34.4 & 19.5 & 16.9 & 9.9 & 8.7 & 8.3 & 13.8 & 24.5 & 8.4 & 8.4 \\
\hline $35-75$ & 59.6 & 77.1 & 75.8 & 82.3 & 88.3 & 89.4 & 79.5 & 73.4 & 85.4 & 85.7 \\
\hline$>75$ & 5.9 & 3.4 & 7.2 & 7.7 & 3.0 & 2.3 & 6.7 & 2.1 & 6.2 & 5.9 \\
\hline \multicolumn{11}{|c|}{ Daytona 100} \\
\hline$\leq 35$ & 30.1 & 10.5 & 12.4 & 3.4 & 2.7 & 12.2 & 6.6 & 4.9 & 6.0 & 4.8 \\
\hline $35-75$ & 53.7 & 48.0 & 56.5 & 70.3 & 68.0 & 69.4 & 73.5 & 83.3 & 88.4 & 86.1 \\
\hline$>75$ & 16.2 & 41.5 & 31.1 & 26.3 & 29.3 & 18.3 & 19.9 & 11.8 & 5.6 & 9.1 \\
\hline
\end{tabular}



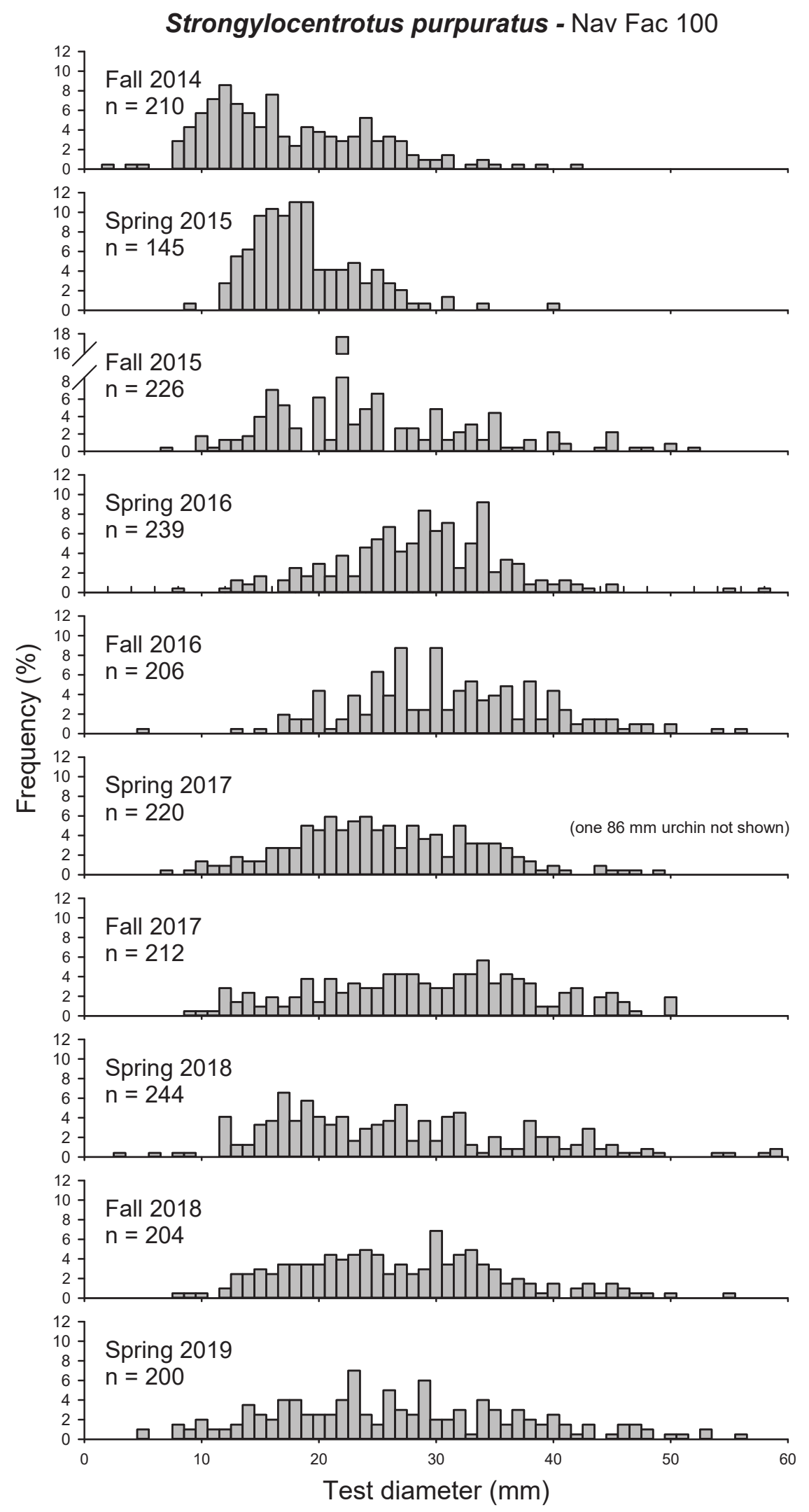

Figure 19. Nav Fac 100 size structure of purple urchins (Strongylocentrotus purpuratus) in fall 2014-spring 2019. [ $n=$ number of individuals] 
Strongylocentrotus franciscanus - Nav Fac 100

Fall 2014

$\mathrm{n}=209$

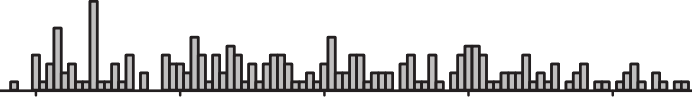

Spring 2015

$\mathrm{n}=198$

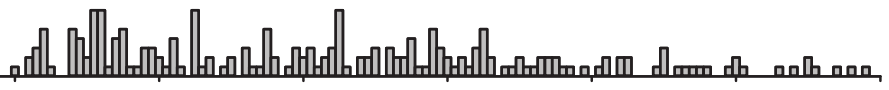

Fall 2015

$n=223$

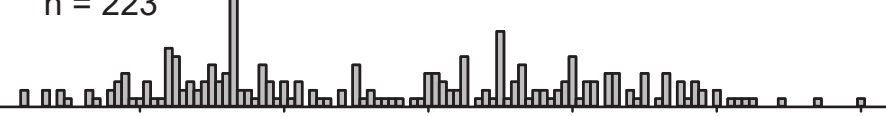

Spring 2016

$\mathrm{n}=174$
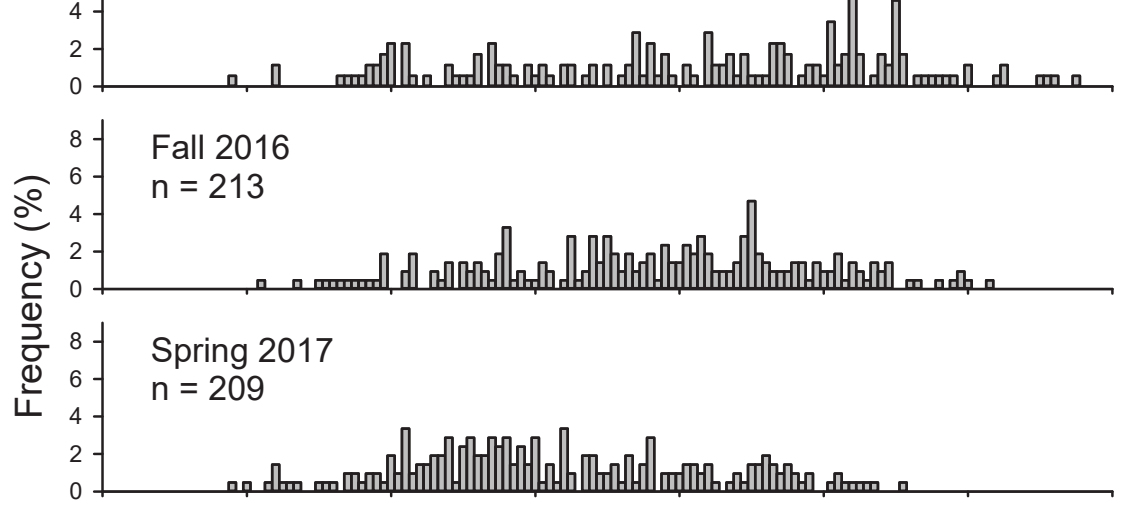

Fall 2017

$\mathrm{n}=204$

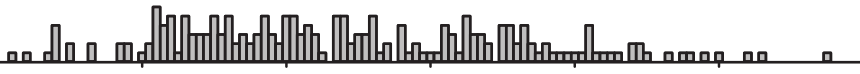

Spring 2018

$\mathrm{n}=229$

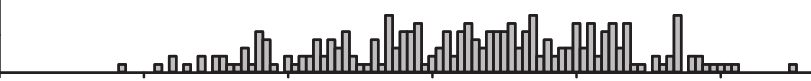

8 Fall 2018

$n=205$

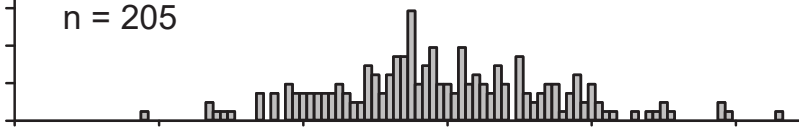

8 Spring 2019

$\mathrm{n}=205$

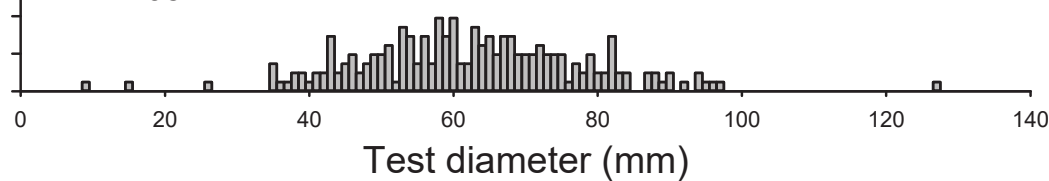

Figure 20. Nav Fac 100 size structure of red urchins (Strongylocentrotus franciscanus) in fall 2014-spring 2019. [ $\mathrm{n}=$ number of individuals] 
The mean numbers of organisms counted in $1-\mathrm{m}^{2}$ quadrats is shown in table 12. The orange puffball sponge (Tethya aurantia) continued to be present at low densities but declined slightly in year 5 . The invasive alga $S$. horneri declined also (like it did in the swath counts). Total counts of this species in quadrats declined from 130 in spring 2017 to 83 in spring 2018, and then to 31 in spring 2019. The number of cover points scored however, was almost identical for these first 2 periods ( 93 and 95 respectively) but dropped to 20 in spring 2019.

Cover data collected from RPC quadrats are summarized in figure 21 as categories of cover at the different supersites over time. The amount of exposed bare rock gradually declined at Nav Fac 100 after the 2015 decline in purple urchin density. Conversely, brown algae (here a mix of Dictyota binghamiae, Dictyopteris undulata, C. osmundacea, Taonia lennabackerae, and $S$. horneri) has become one of the dominant cover categories since 2015. There is a marked seasonal component to the brown algae cover, with spring cover nearly twice as high. Although the spring cover of this category remained constant, the portion contributed by $S$. horneri dropped considerably. Sargassum horneri, which had been the species with the third highest cover in spring 2017 and spring 2018, dropped to eighth ranking in spring 2019 (table 13). Encrusting coralline algae, D. binghamiae and C. osmundacea were the top ranked cover species. The sand castle worm (Phragmatopoma californica) gradually declined from the peak cover it achieved in fall 2017 (14.25 percent); by spring 2019 , it had dropped to 1.75 percent cover but ranked second after the scaled tube snail (S. squamiger) as the most common invertebrate cover.

Nav Fac 100 continued to have the least number of fish species of any of the supersites, but the densities of fish, though lowest of all the supersites in fall 2018, exceeded those measured at West End in spring 2019 (table 14). The schooling species señorita $($ O. californica) and blacksmith (C. punctipinnis) made up most of the count, but kelp bass (Paralabrax clathratus) and sheephead (S. pulcher) were regular members of the fish assemblage at the site (table 15). Three fish transects run west from the main line, over a flat uniform benthos that was mostly devoid of refuge and kelp, whereas the remaining two fish transects run east of the main line, over an area with more habitat heterogeneity, including rocky ridges, boulders, and ledges. Greater fish abundance and diversity was routinely observed on the two easterly transects compared to the three transects that traverse flat bottom to the west.

Table 12. Mean (and standard deviation) numbers of rare species counted on twenty 1-square meter quadrats from Nav Fac 100, fall 2014 through spring 2019.

\begin{tabular}{ccccccccccc}
\hline \multirow{2}{*}{ Species name } & Fall & Spring & Fall & Spring & Fall & Spring & Fall & Spring & Fall & Spring \\
& $\mathbf{2 0 1 4}$ & $\mathbf{2 0 1 5}$ & $\mathbf{2 0 1 5}$ & $\mathbf{2 0 1 6}$ & $\mathbf{2 0 1 6}$ & $\mathbf{2 0 1 7}$ & $\mathbf{2 0 1 7}$ & $\mathbf{2 0 1 8}$ & $\mathbf{2 0 1 8}$ & $\mathbf{2 0 1 9}$ \\
\hline \multirow{2}{*}{ Lithopoma gibberosa } & 0 & 0 & 0 & 0 & 0 & 0 & 0 & 0 & 0 & 0 \\
Cypraea spadicea & $(0.00)$ & $(0.00)$ & $(0.00)$ & $(0.00)$ & $(0.00)$ & $(0.00)$ & $(0.00)$ & $(0.00)$ & $(0.00)$ & $(0.00)$ \\
& 0 & 0 & 0 & 0 & 0 & 0.1 & 0.1 & 0.1 & 0 & 0.1 \\
Kelletia kelletii & $(0.00)$ & $(0.00)$ & $(0.00)$ & $(0.00)$ & $(0.00)$ & $(0.22)$ & $(0.22)$ & $(0.22)$ & $(0.00)$ & $(0.22)$ \\
Norrisia norrisi & 0 & 0 & 0.3 & 0 & 0.1 & 0.1 & 0 & 0.1 & 0.2 & 0.1 \\
& $(0.00)$ & $(0.00)$ & $(0.80)$ & $(0.00)$ & $(0.31)$ & $(0.45)$ & $(0.00)$ & $(0.22)$ & $(0.49)$ & $(0.22)$ \\
Sargassum horneri & 0 & 0 & 0 & 0.2 & 0.1 & 0.1 & 0 & 0.2 & 0.1 & 0.3 \\
Styela montereyensis & $(0.00)$ & $(0.00)$ & $(0.00)$ & $(0.49)$ & $(0.22)$ & $(0.31)$ & $(0.00)$ & $(0.37)$ & $(0.31)$ & $(0.57)$ \\
Tegula regina & 0 & 0 & 0.05 & 0 & 4.7 & 6.5 & 3.3 & 4.2 & 2.1 & 1.6 \\
& $(0.00)$ & $(0.00)$ & $(0.00)$ & $(0.00)$ & $(0.49)$ & $(0.22)$ & $(0.00)$ & $(0.00)$ & $(0.00)$ & $(0.00)$ \\
Tethya aurantia & 0 & 0 & 0 & 0 & 0 & 0 & 0 & 0 & 0 & 0 \\
Tealia lofotensis & $(0.00)$ & $(0.00)$ & $(0.00)$ & $(0.00)$ & $(0.00)$ & $(0.00)$ & $(0.00)$ & $(0.00)$ & $(0.00)$ & $(0.00)$ \\
& 0.5 & 0.3 & 0.4 & 0.2 & 0.4 & 0.3 & 0.3 & 0.2 & 0.1 & 0.1 \\
& $(0.69)$ & $(0.55)$ & $(0.59)$ & $(0.52)$ & $(0.67)$ & $(0.44)$ & $(0.44)$ & $(0.37)$ & $(0.31)$ & $(0.22)$ \\
& 0 & 0 & 0 & 0 & 0.2 & 0 & 0 & 0 & 0 & 0 \\
& $(0.00)$ & $(0.00)$ & $(0.00)$ & $(0.00)$ & $(0.89)$ & $(0.00)$ & $(0.00)$ & $(0.00)$ & $(0.00)$ & $(0.00)$ \\
\hline
\end{tabular}




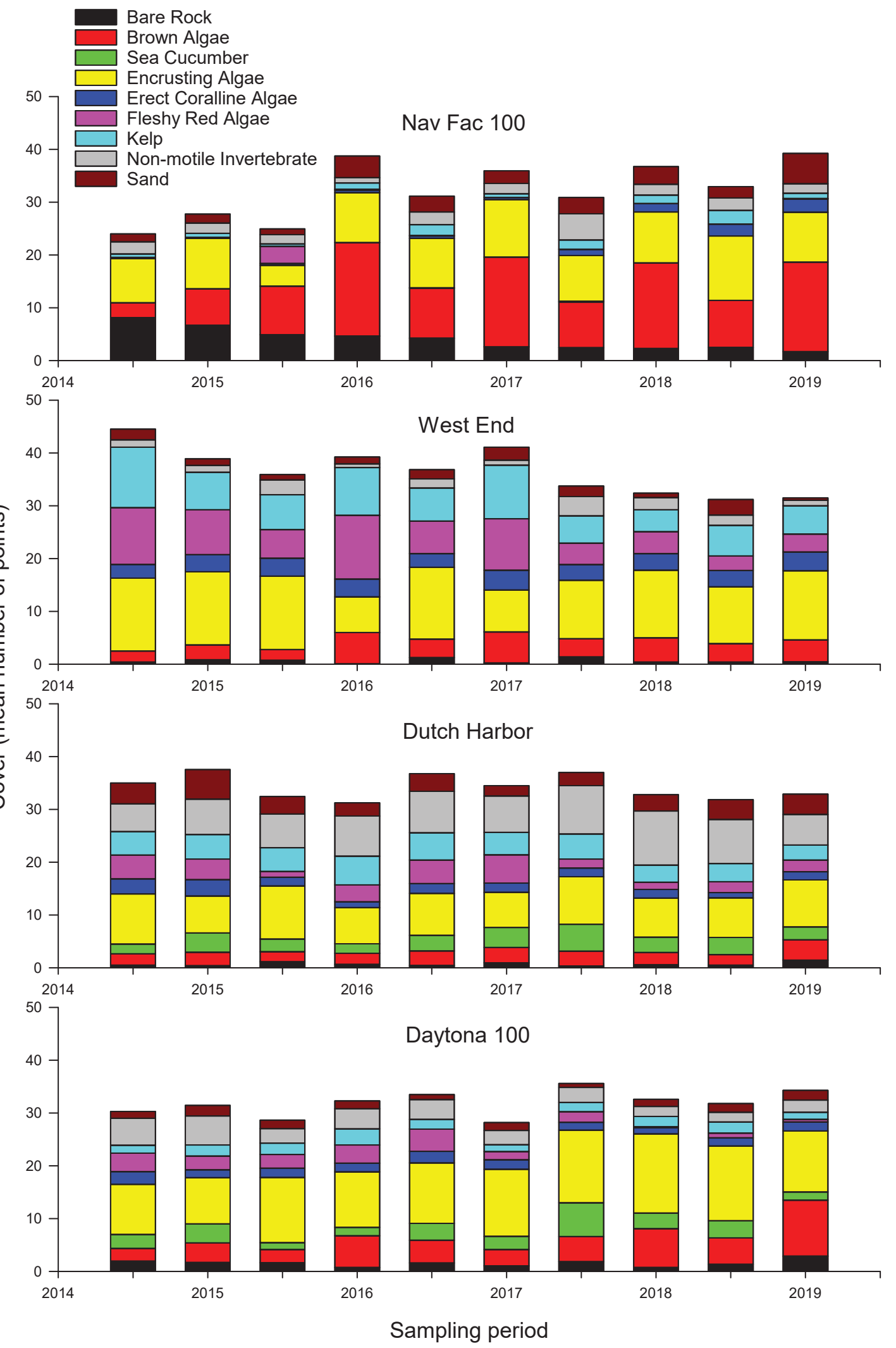

Figure 21. Mean percent cover categories by supersite in fall 2014 through spring 2019. [Categories are bare rock (black), brown algae (non-kelp; red), sea cucumbers (green), encrusting algae (yellow), erect coralline algae (blue), fleshy red algae (pink), kelp (turquoise), non-motile invertebrates (gray) and sand (brown)] 
Table 13. Nav Fac 100 point contact "species" ranked by the sum of points for fall 2014 through spring 2019.

[>, greater than; $\mathrm{m}$, meter; $<$, less than]

\begin{tabular}{|c|c|c|c|c|c|c|c|c|c|c|}
\hline Species name & $\begin{array}{l}\text { Fall } \\
2014\end{array}$ & $\begin{array}{c}\text { Spring } \\
2015\end{array}$ & $\begin{array}{l}\text { Fall } \\
2015\end{array}$ & $\begin{array}{c}\text { Spring } \\
2016\end{array}$ & $\begin{array}{l}\text { Fall } \\
2016\end{array}$ & $\begin{array}{c}\text { Spring } \\
2017\end{array}$ & $\begin{array}{l}\text { Fall } \\
2017\end{array}$ & $\begin{array}{c}\text { Spring } \\
2018\end{array}$ & $\begin{array}{l}\text { Fall } \\
2018\end{array}$ & $\begin{array}{c}\text { Spring } \\
2019\end{array}$ \\
\hline Encrusting coralline algae & 164 & 191 & 79 & 186 & 182 & 218 & 172 & 193 & 237 & 188 \\
\hline Dictyota binghamiae & 36 & 33 & 7 & 135 & 70 & 126 & 99 & 111 & 47 & 157 \\
\hline Bare substratum & 163 & 134 & 98 & 93 & 85 & 52 & 49 & 46 & 50 & 34 \\
\hline Cystoseira osmundacea & 11 & 18 & 39 & 77 & 57 & 68 & 67 & 88 & 107 & 131 \\
\hline Sand & 30 & 34 & 22 & 82 & 60 & 48 & 62 & 67 & 43 & 115 \\
\hline Dictyopteris undulata & 9 & 84 & 50 & 93 & 45 & 29 & 1 & 22 & 20 & 30 \\
\hline Sargassum horneri & 0 & 0 & 1 & 0 & 8 & 93 & 3 & 95 & 0 & 20 \\
\hline Corallina officinalis & 4 & 2 & 7 & 6 & 7 & 7 & 16 & 23 & 34 & 32 \\
\hline Phragmatopoma californica & 0 & 0 & 0 & 0 & 11 & 21 & 57 & 20 & 19 & 7 \\
\hline Pterygophora californica & 7 & 9 & 5 & 17 & 9 & 5 & 9 & 12 & 28 & 15 \\
\hline Serpulorbis squamiger & 12 & 10 & 9 & 6 & 13 & 8 & 11 & 7 & 15 & 16 \\
\hline Unidentified brown algae & 0 & 0 & 77 & 0 & 0 & 0 & 0 & 0 & 0 & 0 \\
\hline Filamentous red algae & 0 & 1 & 63 & 0 & 0 & 0 & 0 & 0 & 0 & 0 \\
\hline Taonia lennebackerae & 0 & 2 & 0 & 33 & 0 & 23 & 1 & 1 & 0 & 0 \\
\hline Barnacle & 23 & 15 & 2 & 0 & 0 & 0 & 0 & 0 & 0 & 0 \\
\hline Kelp holdfast & 0 & 0 & 1 & 0 & 10 & 2 & 14 & 6 & 3 & 1 \\
\hline Eisenia arborea & 5 & 4 & 0 & 2 & 4 & 4 & 1 & 6 & 8 & 2 \\
\hline Calliarthron spp. & 1 & 0 & 0 & 3 & 2 & 1 & 2 & 7 & 6 & 13 \\
\hline Mucus tube polychaete & 0 & 2 & 20 & 0 & 9 & 0 & 0 & 0 & 0 & 0 \\
\hline Macrocystis pyrifera $>1 \mathrm{~m}$ & 0 & 0 & 0 & 0 & 14 & 1 & 7 & 2 & 6 & 0 \\
\hline Pink encrusting bryozoan & 0 & 0 & 0 & 0 & 2 & 2 & 18 & 3 & 2 & 3 \\
\hline Laminaria spp. & 1 & 1 & 1 & 3 & 2 & 1 & 4 & 2 & 7 & 2 \\
\hline Astrangia lajollaensis [haimei] & 4 & 3 & 0 & 0 & 1 & 3 & 4 & 2 & 1 & 5 \\
\hline Encrusting red algae & 3 & 0 & 0 & 3 & 5 & 0 & 1 & 0 & 7 & 1 \\
\hline Sargassum muticum & 0 & 0 & 7 & 4 & 8 & 0 & 0 & 1 & 0 & 0 \\
\hline Bossiella spp. & 0 & 1 & 0 & 1 & 0 & 0 & 5 & 2 & 5 & 5 \\
\hline Zonaria farlowii & 0 & 0 & 3 & 0 & 1 & 1 & 2 & 6 & 4 & 1 \\
\hline Diopatra ornate & 1 & 1 & 0 & 0 & 3 & 0 & 3 & 3 & 2 & 1 \\
\hline Orange encrusting sponge & 2 & 2 & 1 & 3 & 1 & 0 & 1 & 0 & 4 & 0 \\
\hline Filamentous brown algae & 0 & 0 & 0 & 11 & 0 & 0 & 0 & 0 & 0 & 0 \\
\hline Balanus spp. & 0 & 0 & 0 & 7 & 1 & 0 & 0 & 0 & 2 & 0 \\
\hline Tethya aurantia & 2 & 1 & 2 & 3 & 0 & 0 & 0 & 1 & 0 & 0 \\
\hline Diatom film & 8 & 0 & 0 & 0 & 0 & 0 & 0 & 0 & 0 & 0 \\
\hline Macrocystis pyrifera $<1 \mathrm{~m}$ & 0 & 1 & 2 & 2 & 1 & 1 & 0 & 1 & 0 & 0 \\
\hline Codium fragile & 0 & 2 & 0 & 0 & 0 & 5 & 0 & 0 & 0 & 0 \\
\hline Metandrocarpa dura & 0 & 0 & 0 & 0 & 0 & 0 & 2 & 4 & 1 & 0 \\
\hline Balanophyllia elegans & 2 & 1 & 1 & 0 & 1 & 0 & 0 & 0 & 1 & 0 \\
\hline Pholad clam & 0 & 3 & 0 & 0 & 2 & 1 & 0 & 0 & 0 & 0 \\
\hline Spirobranchus spinosus & 0 & 1 & 0 & 0 & 0 & 2 & 0 & 0 & 0 & 3 \\
\hline Cryptopleura spp. & 0 & 0 & 1 & 3 & 1 & 0 & 0 & 0 & 0 & 0 \\
\hline Young Laminariales & 0 & 0 & 0 & 0 & 1 & 0 & 0 & 3 & 0 & 0 \\
\hline Laurencia pacifica & 0 & 0 & 0 & 0 & 0 & 0 & 1 & 0 & 0 & 2 \\
\hline
\end{tabular}


Table 13. Nav Fac 100 point contact "species" ranked by the sum of points for fall 2014 through spring 2019.—Continued $[>$, greater than; $\mathrm{m}$, meter; $<$, less than]

\begin{tabular}{|c|c|c|c|c|c|c|c|c|c|c|}
\hline \multirow{2}{*}{ Species name } & \multicolumn{3}{|c|}{ Spring } & \multirow{2}{*}{$\begin{array}{c}\text { Spring } \\
2016\end{array}$} & \multirow[b]{2}{*}{ Fall 2016} & \multirow{2}{*}{$\begin{array}{c}\text { Spring } \\
2017\end{array}$} & \multirow[b]{2}{*}{ Fall 2017} & \multirow{2}{*}{$\begin{array}{c}\text { Spring } \\
2018\end{array}$} & \multirow[b]{2}{*}{ Fall 2018} & \multirow{2}{*}{$\begin{array}{c}\text { Spring } \\
2019\end{array}$} \\
\hline & Fall 2014 & 2015 & Fall 2015 & & & & & & & \\
\hline Archidistoma $[$ Eudistoma] psammion & 0 & 0 & 0 & 0 & 0 & 1 & 1 & 0 & 0 & 0 \\
\hline Cucumaria salma & 0 & 1 & 0 & 0 & 0 & 0 & 1 & 0 & 0 & 0 \\
\hline Cystodytes lobatus & 0 & 0 & 0 & 0 & 1 & 1 & 0 & 0 & 0 & 0 \\
\hline Lissothuria nutriens & 0 & 0 & 0 & 0 & 0 & 0 & 2 & 0 & 0 & 0 \\
\hline Unidentified sponge & 0 & 0 & 0 & 0 & 1 & 0 & 0 & 1 & 0 & 0 \\
\hline Anthopleura sola & 0 & 0 & 0 & 0 & 1 & 0 & 0 & 0 & 0 & 0 \\
\hline Boltenia villosa & 0 & 0 & 0 & 0 & 0 & 0 & 1 & 0 & 0 & 0 \\
\hline Corynactis californica & 0 & 0 & 0 & 0 & 0 & 0 & 0 & 0 & 0 & 1 \\
\hline Cucumaria piperata & 0 & 0 & 0 & 0 & 1 & 0 & 0 & 0 & 0 & 0 \\
\hline Desmarestia ligulate & 0 & 0 & 0 & 1 & 0 & 0 & 0 & 0 & 0 & 0 \\
\hline Eupentacta quinquesemita & 0 & 0 & 0 & 0 & 1 & 0 & 0 & 0 & 0 & 0 \\
\hline Halichondria spp. & 0 & 0 & 0 & 1 & 0 & 0 & 0 & 0 & 0 & 0 \\
\hline Lagenocella spp. & 0 & 0 & 0 & 0 & 1 & 0 & 0 & 0 & 0 & 0 \\
\hline Nienburgia andersoniana & 0 & 0 & 0 & 0 & 1 & 0 & 0 & 0 & 0 & 0 \\
\hline Pterosiphonia spp. & 0 & 0 & 1 & 0 & 0 & 0 & 0 & 0 & 0 & 0 \\
\hline Strongylocentrotus franciscanus & 0 & 0 & 0 & 1 & 0 & 0 & 0 & 0 & 0 & 0 \\
\hline Stylantheca porphyra [papillosa $]$ & 0 & 0 & 0 & 0 & 0 & 0 & 1 & 0 & 0 & 0 \\
\hline
\end{tabular}

Table 14. Number of fish species counted, total count, density on benthic and midwater transects, and number of fish sized at each supersite in fall 2014 through spring 2019.

[Densities are given in terms of area rather than volume because the volume of midwater transects is variable. Abbreviation: $\mathrm{m}^{2}$, square meter]

\begin{tabular}{|c|c|c|c|c|c|c|}
\hline \multirow[b]{2}{*}{ Supersite } & \multirow{2}{*}{$\begin{array}{c}\text { Number } \\
\text { of } \\
\text { species }\end{array}$} & \multirow[b]{2}{*}{$\begin{array}{l}\text { Total } \\
\text { count }\end{array}$} & \multicolumn{3}{|c|}{ Density } & \multirow[b]{2}{*}{$\begin{array}{c}\text { Number } \\
\text { sized }\end{array}$} \\
\hline & & & $\begin{array}{c}\text { Overall } \\
/ \mathrm{m}^{2}\end{array}$ & $\begin{array}{c}\text { Benthic } \\
/ \mathrm{m}^{2}\end{array}$ & $\begin{array}{c}\text { Midwater } \\
/ \mathrm{m}^{2}\end{array}$ & \\
\hline \multicolumn{7}{|c|}{ Year 1: Fall 2014} \\
\hline Nav Fac 100 & 19 & 732 & 0.42 & 0.84 & 0.25 & 732 \\
\hline West End & 22 & 4,022 & 1.15 & 1.15 & 1.15 & 4,022 \\
\hline Dutch Harbor & 25 & 8,841 & 2.53 & 1.67 & 2.87 & 3,148 \\
\hline Daytona 100 & 19 & 3,592 & 2.05 & 1.70 & 2.19 & 3,592 \\
\hline \multicolumn{7}{|c|}{ Year 1: Spring 2015} \\
\hline Nav Fac 100 & 11 & 136 & 0.08 & 0.27 & 0.00 & 136 \\
\hline West End & 13 & 958 & 0.27 & 0.05 & 0.36 & 958 \\
\hline Dutch Harbor & 23 & 4,503 & 1.30 & 1.43 & 1.23 & 2,072 \\
\hline Daytona 100 & 19 & 990 & 0.57 & 0.89 & 0.44 & 990 \\
\hline \multicolumn{7}{|c|}{ Year 2: Fall 2015} \\
\hline Nav Fac 100 & 12 & 344 & 0.20 & 0.57 & 0.05 & 344 \\
\hline West End & 17 & 2,677 & 0.76 & 1.41 & 0.51 & 2,677 \\
\hline
\end{tabular}


Table 14. Number of fish species counted, total count, density on benthic and midwater transects, and number of fish sized at each supersite in fall 2014 through spring 2019.-Continued

[Densities are given in terms of area rather than volume because the volume of midwater transects is variable. Abbreviation: $\mathrm{m}^{2}$, square meter]

\begin{tabular}{|c|c|c|c|c|c|c|}
\hline \multirow[b]{2}{*}{ Supersite } & \multirow{2}{*}{$\begin{array}{c}\text { Number } \\
\text { of spe- } \\
\text { cies }\end{array}$} & \multirow{2}{*}{$\begin{array}{l}\text { Total } \\
\text { count }\end{array}$} & \multicolumn{3}{|c|}{ Density } & \multirow{2}{*}{$\begin{array}{c}\text { Number } \\
\text { sized }\end{array}$} \\
\hline & & & $\begin{array}{c}\text { Overall } \\
/ \mathrm{m}^{2}\end{array}$ & $\begin{array}{c}\text { Benthic } \\
/ \mathrm{m}^{2}\end{array}$ & $\begin{array}{c}\text { Midwater } \\
/ \mathrm{m}^{2}\end{array}$ & \\
\hline Dutch Harbor & 27 & 4,256 & 1.22 & 1.64 & 1.05 & 1,673 \\
\hline Daytona 100 & 16 & 738 & 0.42 & 0.81 & 0.27 & 738 \\
\hline \multicolumn{7}{|c|}{ Year 2: Spring 2016} \\
\hline Nav Fac 100 & 14 & 1,067 & 0.61 & 1.22 & 0.37 & 1,067 \\
\hline West End & 17 & 1,447 & 0.41 & 0.26 & 0.47 & 1,447 \\
\hline Dutch Harbor & 29 & 2,153 & 0.62 & 0.57 & 0.63 & 947 \\
\hline Daytona 100 & 14 & 336 & 0.19 & 0.31 & 0.15 & 336 \\
\hline \multicolumn{7}{|c|}{ Year 3: Fall 2016} \\
\hline Nav Fac 100 & 17 & 408 & 0.23 & 0.60 & 0.08 & 408 \\
\hline West End & 18 & 1,253 & 0.36 & 0.81 & 0.18 & 1,253 \\
\hline Dutch Harbor & 26 & 3,482 & 1.0 & 0.93 & 1.02 & 1,587 \\
\hline Daytona 100 & 18 & 759 & 0.43 & 0.46 & 0.42 & 759 \\
\hline \multicolumn{7}{|c|}{ Year 3: Spring 2017} \\
\hline Nav Fac 100 & 13 & 1,135 & 0.65 & 0.68 & 0.64 & 1,135 \\
\hline West End & 17 & 1,196 & 0.34 & 0.43 & 0.31 & 1,196 \\
\hline Dutch Harbor & 20 & 2,351 & 0.67 & 0.87 & 0.59 & 1,031 \\
\hline Daytona 100 & 15 & 1,556 & 0.89 & 0.68 & 0.97 & 1,556 \\
\hline \multicolumn{7}{|c|}{ Year 4: Fall 2017} \\
\hline Nav Fac 100 & 11 & 325 & 0.19 & 0.34 & 0.12 & 325 \\
\hline West End & 18 & 303 & 0.09 & 0.22 & 0.03 & 303 \\
\hline Dutch Harbor & 25 & 2,441 & 0.70 & 0.70 & 0.70 & 1,031 \\
\hline Daytona 100 & 22 & 619 & 0.35 & 0.48 & 0.30 & 619 \\
\hline \multicolumn{7}{|c|}{ Year 4: Spring 2018} \\
\hline Nav Fac 100 & 10 & 702 & 0.40 & 0.58 & 0.33 & 702 \\
\hline West End & 17 & 653 & 0.19 & 0.30 & 0.14 & 653 \\
\hline Dutch Harbor & 22 & 2,614 & 0.75 & 0.55 & 0.83 & 1,178 \\
\hline Daytona 100 & 14 & 936 & 0.53 & 1.33 & 0.22 & 936 \\
\hline \multicolumn{7}{|c|}{ Year 5: Fall 2018} \\
\hline Nav Fac 100 & 11 & 149 & 0.09 & 0.12 & 0.07 & 149 \\
\hline West End & 15 & 523 & 0.15 & 0.18 & 0.14 & 523 \\
\hline Dutch Harbor & 24 & 2,201 & 0.63 & 0.63 & 0.63 & 648 \\
\hline Daytona 100 & 16 & 602 & 0.34 & 0.45 & 0.30 & 602 \\
\hline \multicolumn{7}{|c|}{ Year 5: Spring 2019} \\
\hline Nav Fac 100 & 10 & 420 & 0.24 & 0.43 & 0.16 & 420 \\
\hline West End & 15 & 339 & 0.10 & 0.20 & 0.05 & 339 \\
\hline Dutch Harbor & 24 & 3,494 & 1.00 & 0.77 & 1.09 & 1,924 \\
\hline Daytona 100 & 15 & 1,298 & 0.74 & 0.59 & 0.80 & 1,298 \\
\hline
\end{tabular}


Table 15. Nav Fac 100 fish counts_adult (juvenile)—in fall 2014 through spring 2019 by species.

[f, female; $\mathrm{m}$, male]

\begin{tabular}{|c|c|c|c|c|c|c|c|c|c|c|}
\hline Species name & $\begin{array}{l}\text { Fall } \\
2014 \\
\end{array}$ & $\begin{array}{c}\text { Spring } \\
2015\end{array}$ & $\begin{array}{l}\text { Fall } \\
2015 \\
\end{array}$ & $\begin{array}{c}\text { Spring } \\
2016\end{array}$ & $\begin{array}{l}\text { Fall } \\
2016 \\
\end{array}$ & $\begin{array}{c}\text { Spring } \\
2017\end{array}$ & $\begin{array}{l}\text { Fall } \\
2017 \\
\end{array}$ & $\begin{array}{c}\text { Spring } \\
2018 \\
\end{array}$ & $\begin{array}{l}\text { Fall } \\
2018 \\
\end{array}$ & $\begin{array}{c}\text { Spring } \\
2019 \\
\end{array}$ \\
\hline Artedius spp. & 0 & 1 & 0 & 0 & 0 & 0 & 0 & 0 & 0 & 0 \\
\hline Brachyistius frenatus & 1 & 0 & 0 & 0 & 1 & 0 & 0 & 0 & 0 & 3 \\
\hline Caulolatilus princeps & 3 & 0 & 2 & 0 & 0 & 0 & 0 & 0 & 0 & 0 \\
\hline Chromis punctipinnis & 370 & 40 & $117(53)$ & 129 & 245 & 345 & 113 & 149 & 55 & 142 \\
\hline Rhinogobiops nicholsii & 57 & 1 & 5 & 0 & 4 & 1 & 3 & 9 & 1 & 5 \\
\hline Embiotoca jacksoni & 12 & 7 & 4 & 7 & 3 & 11 & 9 & 0 & 15 & 7 \\
\hline Embiotoca lateralis & 2 & 0 & 0 & 0 & 0 & 0 & 0 & 0 & 0 & 0 \\
\hline Galeorhinus galeus & 0 & 0 & 0 & 1 & 0 & 0 & 0 & 0 & 0 & 0 \\
\hline Girella nigricans & 3 & 1 & 2 & 1 & 25 & 1 & 2 & 0 & 2 & 0 \\
\hline Halichoeres semicinctus & 0 & $0(1)$ & 0 & 0 & 1 & 0 & 0 & 1 & 0 & 0 \\
\hline Heterodontus francisci & 0 & 0 & 0 & 0 & 0 & 1 & 0 & 0 & 0 & 0 \\
\hline Hypsurus caryi & 5 & 0 & 0 & 0 & 6 & 0 & 0 & 0 & 0 & 2 \\
\hline Hypsypops rubicundus & 1 & 1 & 2 & 1 & 8 & 6 & 4 & 1 & 4 & 5 \\
\hline Medialuna californiensis & 0 & 0 & 35 & 16 & 3 & 1 & 37 & 1 & 0 & 1 \\
\hline Neoclinus spp. & 0 & 0 & 0 & 0 & 1 & 0 & 0 & 0 & 0 & 0 \\
\hline Oxyjulis californica & 119 & 68 & 45 & 864 & 57 & 721 & 116 & 484 & 37 & 203 \\
\hline Oxylebius pictus & 8 & 2 & 0 & 1 & 0 & 0 & 1 & 0 & 0 & 0 \\
\hline Paralabrax clathratus & 114 & 7 & $26(16)$ & 22 & 9 & 21 & 18 & 14 & 11 & $17(1)$ \\
\hline Rhacochilus vacca & 4 & 0 & 5 & 0 & 1 & 0 & 0 & 1 & 2 & 0 \\
\hline Sebastes atrovirens & 4 & 0 & 2 & 1 & 2 & 0 & 2 & 0 & 1 & 0 \\
\hline Sebastes chrysomelas & 3 & 0 & 0 & 1 & 0 & 0 & 0 & 0 & 0 & 0 \\
\hline Sebastes mystinus & 4 & 0 & 0 & 1 & 2 & 2 & 0 & 0 & 1 & 0 \\
\hline Sebastes rastrelliger & 0 & 0 & 0 & 1 & 0 & 0 & 0 & 0 & 0 & 0 \\
\hline Sebastes serranoides & 0 & 3 & 0 & 0 & 1 & 0 & 0 & 0 & 0 & 0 \\
\hline Sebastes serriceps & 1 & 0 & 0 & 0 & 0 & 1 & 0 & 0 & 0 & 0 \\
\hline Semicossyphus pulcher (f) & 17 & $2(1)$ & $23(3)$ & $15(2)$ & $32(6)$ & 21 & 20 & 35 & 19 & 27 \\
\hline Semicossyphus pulcher (m) & 3 & 1 & 4 & 4 & 1 & 1 & 0 & 6 & 1 & 7 \\
\hline Stereolepis gigas & 0 & 0 & 0 & 0 & 0 & 2 & 0 & 1 & 0 & 0 \\
\hline Torpedo californica & 1 & 0 & 0 & 0 & 0 & 0 & 0 & 0 & 0 & 0 \\
\hline
\end{tabular}

\section{West End}

West End continued to be algal-dominated, and the brown alga, C. osmundacea, and the understory kelps, Laminaria spp. and P. californica, remained abundant with little change during the last 5 years (table 16). Figure 22 shows counts of some of the most dynamic species that were counted on the swaths at this supersite. The purple urchin was consistently the most common invertebrate counted on swaths, and their numbers have increased during the last few years. In year 5, their densities were the highest recorded at West End since urchin numbers plummeted there in 2001. Red urchins have followed a very similar trend and also are at their highest level since 2001. Although their densities were about
17 percent of purple urchins in the last sampling periods, they were the second most common invertebrate on swaths. Megastraea undosa densities were near zero 3 years ago but have steadily increased since then. Though still far below the urchin species, they now rank as the third most common invertebrate in the swath counts at this supersite. Like at Nav Fac 100, the increase at West End seemed not to result from recruitment of young individuals; shell diameters less than $40 \mathrm{~mm}$ accounted for only $4-16$ percent of the last three samples. It appears that three waves of $M$. pyrifera recruitment have occurred during the last 5 years, but only two peaks in the density of "adult" M. pyrifera (those greater than $1 \mathrm{~m}$ tall) were apparent during this period (seen in fall 2016 and spring 2019). 
Table 16. West End mean (standard deviation) swath counts for fall 2014 through spring 2019 expressed as individuals per 20-square meter transect.

$[>$, greater than; $\mathrm{m}$, meter; $<$, less than $]$

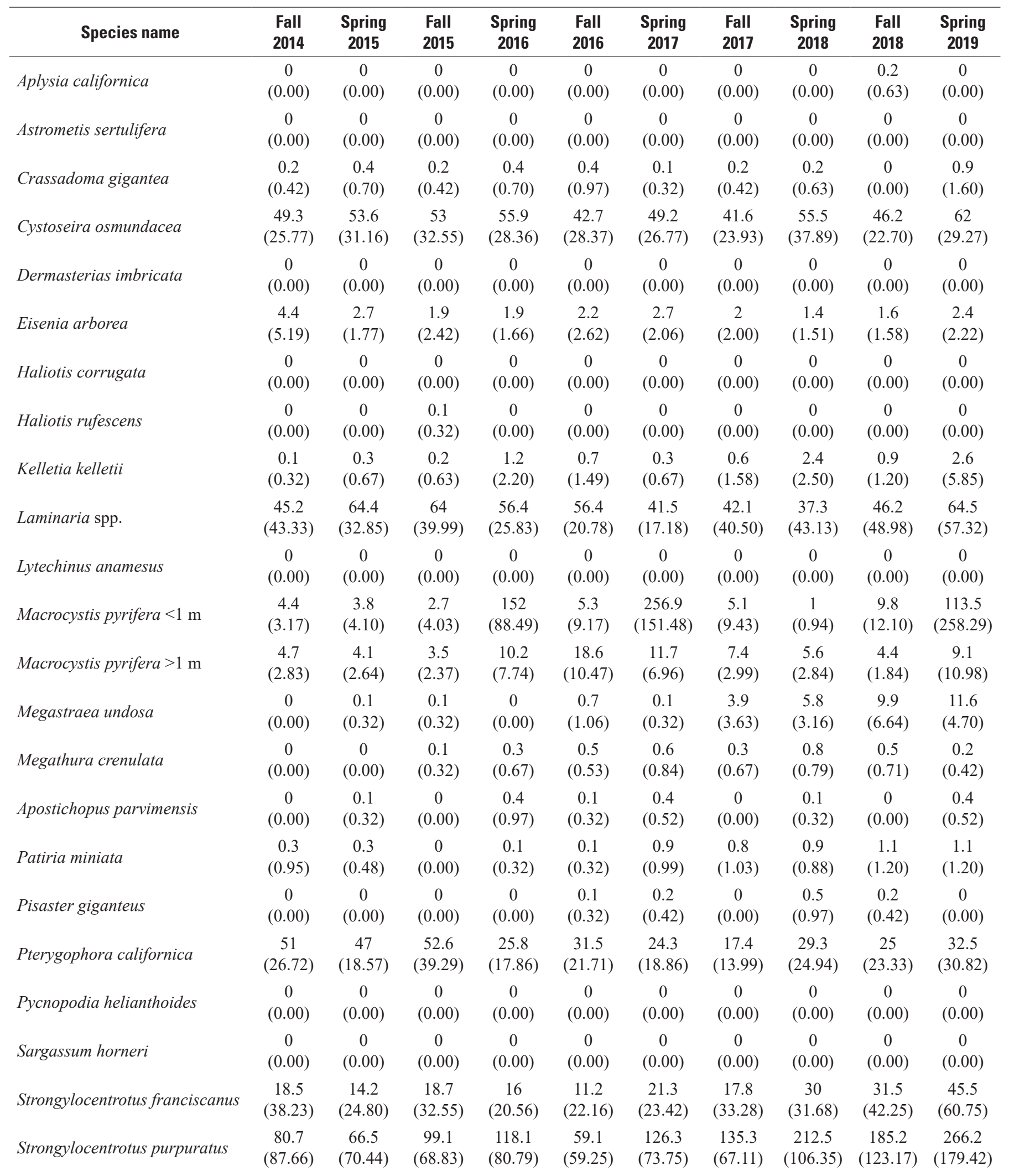


Table 16. West End mean (standard deviation) swath counts for fall 2014 through spring 2019 expressed as individuals per 20-square meter transect.-Continued

[>, greater than; $\mathrm{m}$, meter; $<$, less than]

\begin{tabular}{|c|c|c|c|c|c|c|c|c|c|c|}
\hline Species name & $\begin{array}{l}\text { Fall } \\
2014 \\
\end{array}$ & $\begin{array}{c}\text { Spring } \\
2015\end{array}$ & $\begin{array}{l}\text { Fall } \\
2015\end{array}$ & $\begin{array}{c}\text { Spring } \\
2016\end{array}$ & $\begin{array}{l}\text { Fall } \\
2016\end{array}$ & $\begin{array}{c}\text { Spring } \\
2017\end{array}$ & $\begin{array}{l}\text { Fall } \\
2017\end{array}$ & $\begin{array}{c}\text { Spring } \\
2018\end{array}$ & $\begin{array}{l}\text { Fall } \\
2018\end{array}$ & $\begin{array}{c}\text { Spring } \\
2019\end{array}$ \\
\hline Tethya aurantia & $\begin{array}{c}2.8 \\
(2.66)\end{array}$ & $\begin{array}{c}3.8 \\
(2.94)\end{array}$ & $\begin{array}{c}2.8 \\
(3.58)\end{array}$ & $\begin{array}{c}2.5 \\
(2.68)\end{array}$ & $\begin{array}{c}3.2 \\
(2.90)\end{array}$ & $\begin{array}{c}2.5 \\
(3.10)\end{array}$ & $\begin{array}{c}2.2 \\
(2.78)\end{array}$ & $\begin{array}{c}2.9 \\
(3.14)\end{array}$ & $\begin{array}{c}2.2 \\
(2.49)\end{array}$ & $\begin{array}{c}2.5 \\
(2.88)\end{array}$ \\
\hline Tealia lofotensis & $\begin{array}{c}0.9 \\
(1.91)\end{array}$ & $\begin{array}{c}2 \\
(2.05)\end{array}$ & $\begin{array}{c}0.4 \\
(0.97)\end{array}$ & $\begin{array}{c}0.5 \\
(0.71)\end{array}$ & $\begin{array}{c}0.8 \\
(0.92)\end{array}$ & $\begin{array}{c}0.9 \\
(1.20)\end{array}$ & $\begin{array}{c}0.9 \\
(1.29)\end{array}$ & $\begin{array}{c}0.2 \\
(0.63)\end{array}$ & $\begin{array}{c}0.7 \\
(1.57)\end{array}$ & $\begin{array}{c}0.7 \\
(1.57)\end{array}$ \\
\hline Young Laminariales & $\begin{array}{c}7.3 \\
(8.59)\end{array}$ & $\begin{array}{c}5.9 \\
(8.60)\end{array}$ & $\begin{array}{c}6.4 \\
(6.57)\end{array}$ & $\begin{array}{c}67.3 \\
(115.67)\end{array}$ & $\begin{array}{c}5.4 \\
(6.93)\end{array}$ & $\begin{array}{c}39.2 \\
(54.47)\end{array}$ & $\begin{array}{c}41.6 \\
(62.39)\end{array}$ & $\begin{array}{c}38.4 \\
(32.20)\end{array}$ & $\begin{array}{c}23.1 \\
(22.94)\end{array}$ & $\begin{array}{c}56.4 \\
(126.14)\end{array}$ \\
\hline
\end{tabular}

\section{Dynamic swath counted species} mean count / $20 \mathrm{~m}^{2}$ - West End

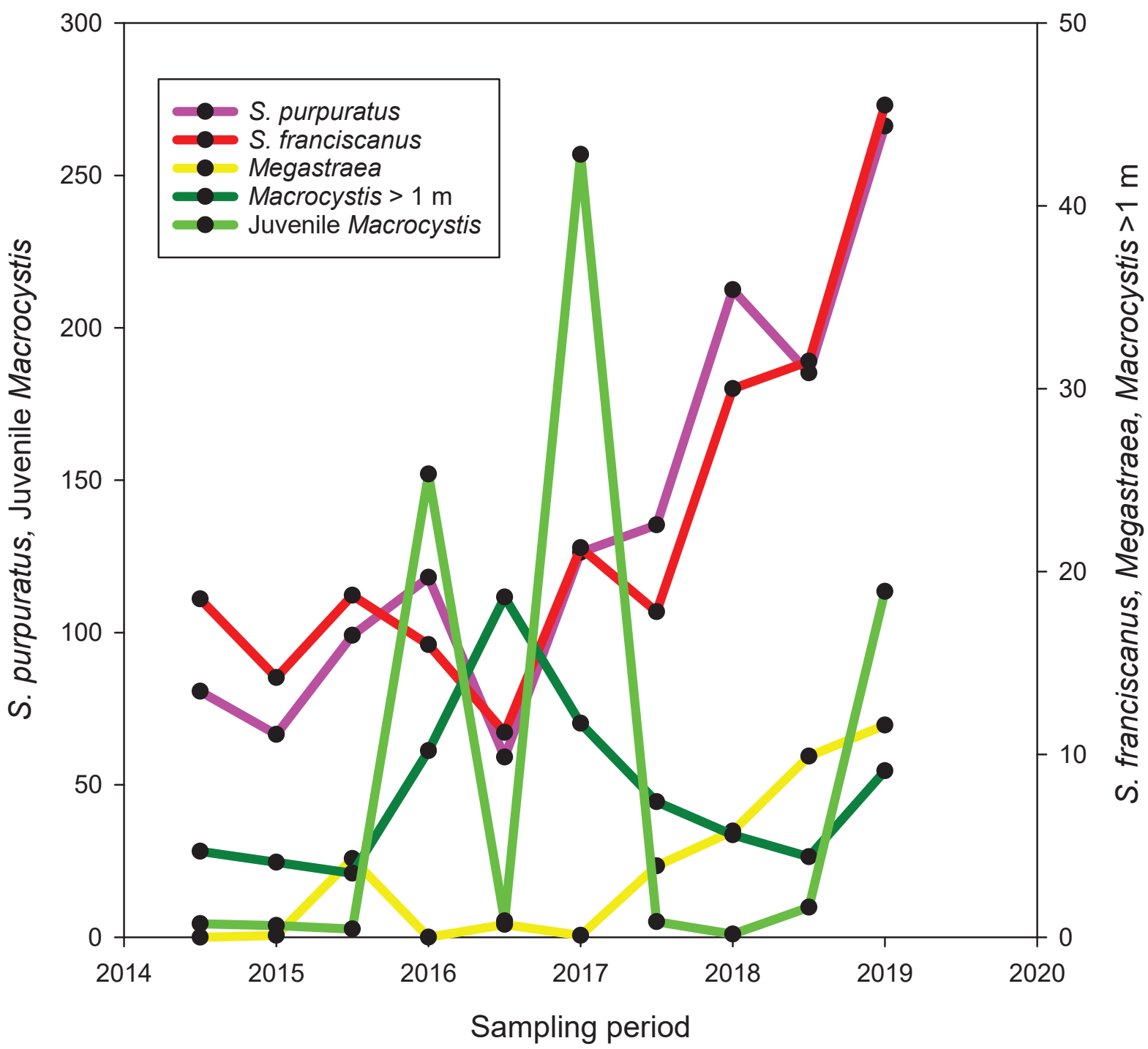

Figure 22. Mean densities of some swath-counted species that have demonstrated changing abundance at West End during the last 5 years. [Note two vertical axes for densities of different species groups] 
West End stipe counts and holdfast diameters of M. pyrifera plants greater than $1 \mathrm{~m}$ tall are plotted in figures 23 and 24. Echoing the earlier-mentioned recruitment pulses, the distributions revealed distinct modes of younger plants apparent in spring 2016-spring 2017 and then again in spring 2019. During the spring 2019 sampling trip, most of the kelps were young and had less than five stipes and holdfasts less than $15 \mathrm{~cm}$. Many of these young plants did not yet reach the surface, which contributed to the sparse canopy observed on the site.

Table 17 provides a summary of the sizes of invertebrates measured on swaths at West End for all seasons. Only Kellet's whelk (K. kelletii) were observed in all sampling periods at West End. However, the rock scallop (Crassadoma gigantea), bat star (P. miniata), and M. undosa were present in most samples. As mentioned earlier in the text, the latter increased in abundance during the last 2 years.

There is a suggestion of recruitment in S. purpuratus in the fall 2018 size data, but it did not appear as a distinct mode (fig. 25). Recruitment also is reflected in the increase in the proportion of the smallest size bin (table 10). The density of this species, as counted on swaths, has more than tripled in 5 years (without any obvious recruitment pulses). The proportions of purple urchin size bins at West End most closely resembled those from Dutch Harbor. Similarly, red urchins (S. franciscanus), although increasing in density in recent sampling periods, showed no distinct recruitment events. There was little change in size distribution apparent in recent periods (fig. 26). This supersite had the lowest proportion of large red urchins of all the sites (table 11), and it is likely that predation by sea otters, which have been concentrating near West End for many years, was responsible for this pattern (Kenner and Tinker, 2018). The low densities of these red urchins, which on this site mostly occurred in crevices and under boulders, made it unlikely that commercial harvest would be a factor.

Of the invertebrate species counted in $1-\mathrm{m}^{2}$ quadrats at West End, only the stalked tunicate (Styela montereyensis) and the orange puffball sponge (T. aurantia) were observed on all sampling trips (table 18). The gastropods, L. gibberosa, C. spadicea, K. kelletii, and N. norrisii, occurred at the site, but were not present in quadrats in more than a few sampling periods.

The West End has the most cover from fleshy red algae of any of the supersites (fig. 21), but that category of cover has declined by about half in the last 2 years there. Encrusting algae, brown algae, erect coralline algae, and kelp were the categories that provided the most bottom cover at West End. The species accounting for most of the remaining cover after encrusting corallines, were the erect coralline Calliarthron spp., encrusting red algae, the brown algae $D$. binghamiae and C. osmundacea, and several species of fleshy red algae (table 19). The understory kelp, Laminaria spp., increased in percent cover but did not reach levels measured prior to fall 2017.

The number of fish species observed at West End declined slightly to 15 on both year 5 sampling trips from the 17 or 18 found there during the previous 6 trips (table 14). The total number of fish counted was similar to the totals there for year 4 but was considerably lower than previous trips. Though overall fish density at West End exceeded what was measured at Nav Fac 100 in fall 2018, that was not the case in spring 2019. The most common fish were the schooling species señorita $($ O. californica) and blacksmith (C. punctipinnis). Blue rockfish (Sebastes mystinus), black perch (Embiotoca jacksoni), and sheephead (S. pulcher) were among the other common species there (table 20). 
Macrocystis pyrifera stipe counts - West End

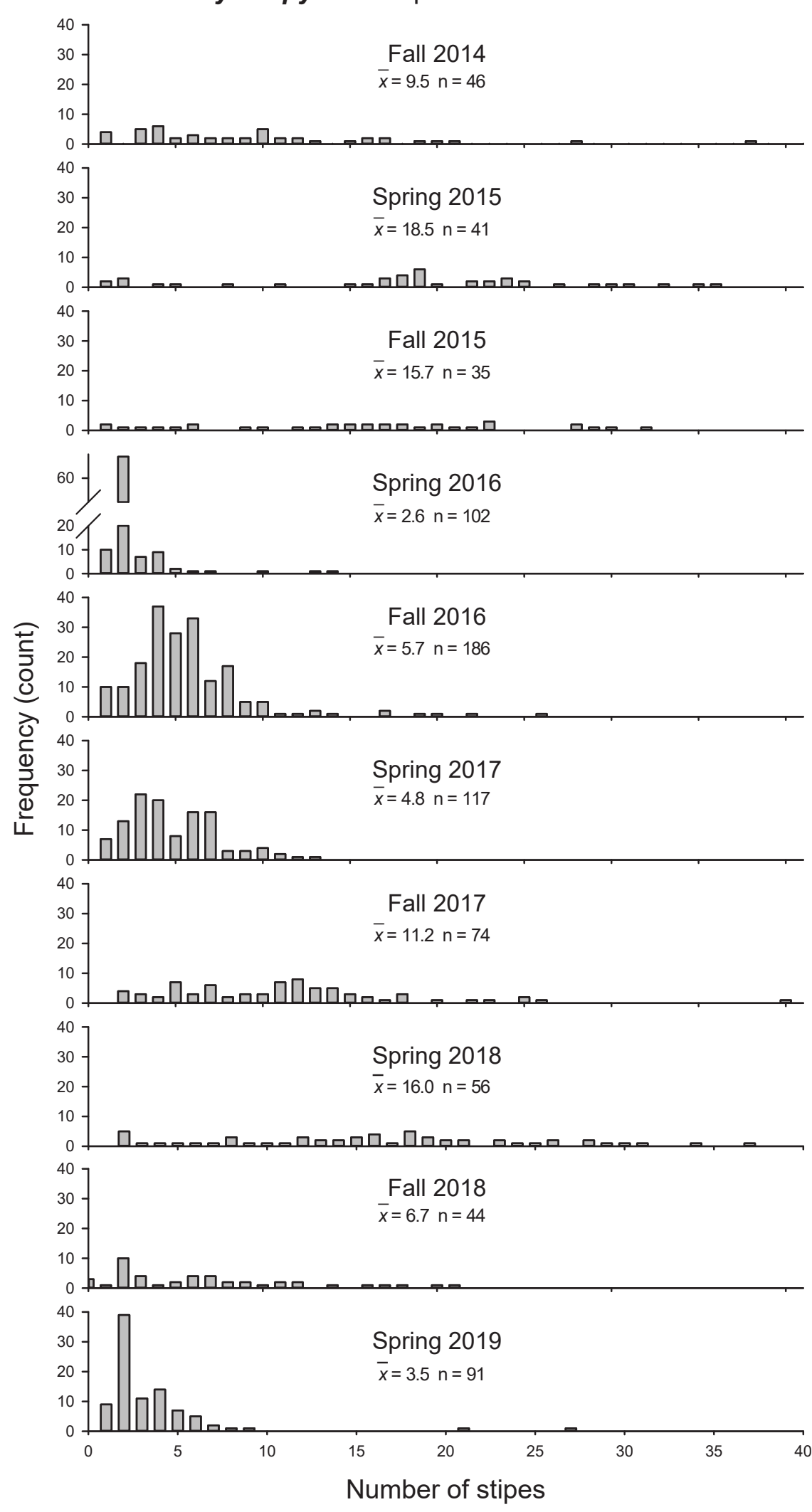

Figure 23. West End Macrocystis pyrifera greater than 1-meter $(\mathrm{m})$ tall stipe counts by season in fall 2014-spring 2019. [ $\bar{X}$ is mean count, $\mathrm{n}$ is number of individuals] 
Macrocystis pyrifera holdfast diameters - West End
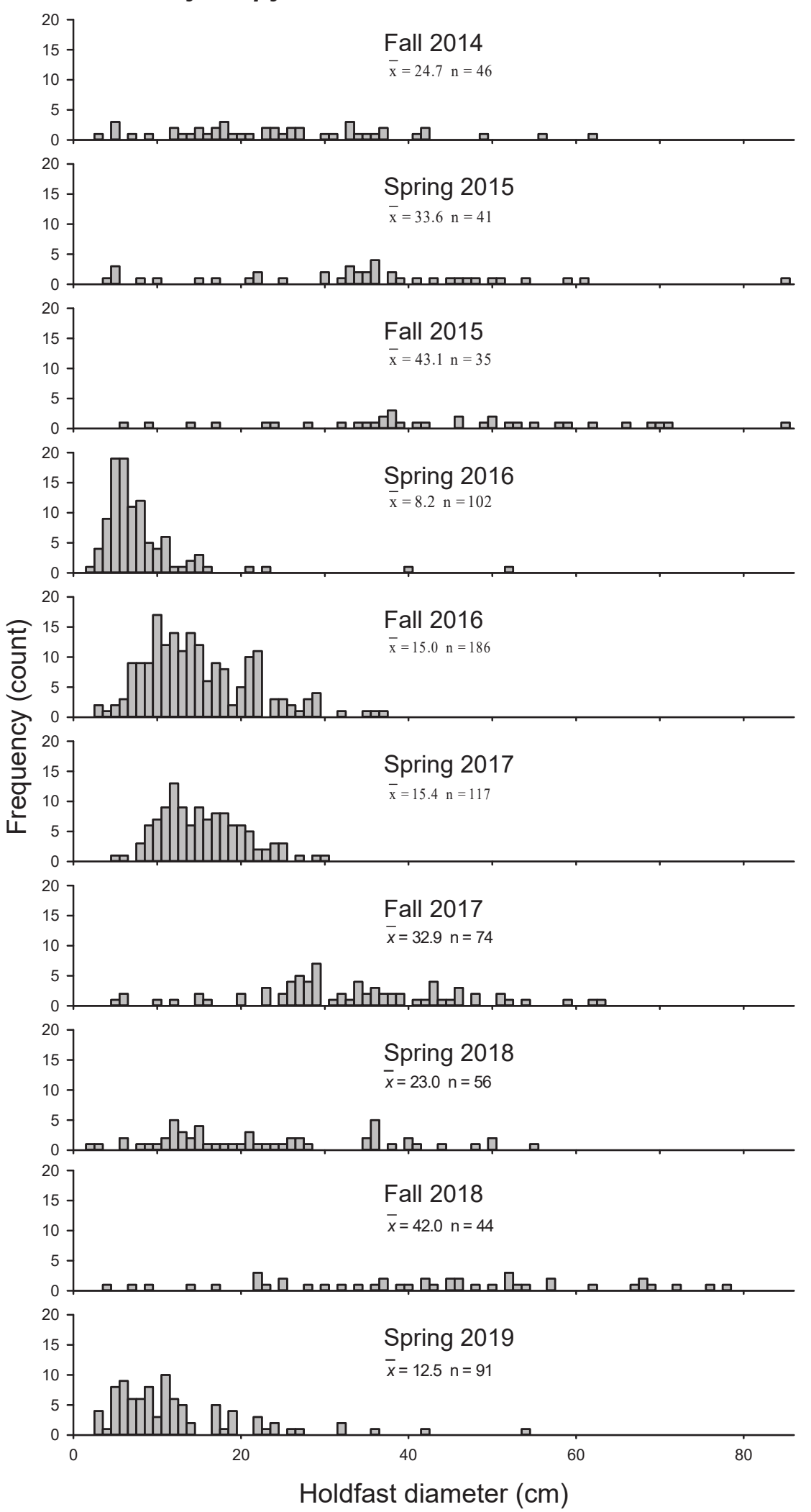

Figure 24. West End Macrocystis pyrifera greater than 1-meter $(\mathrm{m})$ tall holdfast diameters by season in fall 2014-spring 2019. [ $\bar{x}$ is mean diameter, $\mathrm{n}$ is number of individuals] 
Table 17. Sizes of invertebrates measured on swaths at West End in fall 2014 through spring 2019.

[Strongylocentrotus spp. excluded. See figures 25 and 26 for purple and red urchin size data. Abbreviations: N, sample size; Min, minimum; —, no data; Max, maximum]

\begin{tabular}{|c|c|c|c|c|c|c|c|}
\hline \multirow[b]{2}{*}{ Size } & \multicolumn{7}{|c|}{ Species name } \\
\hline & $\begin{array}{c}\text { Crassadoma } \\
\text { gigantea }\end{array}$ & $\begin{array}{c}\text { Haliotis } \\
\text { rufescens }\end{array}$ & $\begin{array}{r}\text { Kelletia } \\
\text { kelletii }\end{array}$ & $\begin{array}{c}\text { Megastraea } \\
\text { undosa }\end{array}$ & $\begin{array}{c}\text { Megathura } \\
\text { crenulata }\end{array}$ & $\begin{array}{l}\text { Patiria } \\
\text { miniata }\end{array}$ & $\begin{array}{c}\text { Pisaster } \\
\text { giganteus }\end{array}$ \\
\hline \multicolumn{8}{|c|}{ Year 1: Fall 2014} \\
\hline $\mathrm{N}$ & 2 & 0 & 1 & 0 & 0 & 3 & 0 \\
\hline Min & 23 & - & 32 & - & - & 22 & - \\
\hline Max & 51 & - & 32 & - & - & 50 & - \\
\hline Mean & 37.0 & - & 32.0 & - & - & 39.0 & - \\
\hline \multicolumn{8}{|c|}{ Year 1: Spring 2015} \\
\hline $\mathrm{N}$ & 4 & 0 & 3 & 1 & 0 & 3 & 0 \\
\hline Min & 18 & - & 25 & 30 & - & 42 & - \\
\hline Max & 52 & - & 43 & 30 & - & 61 & - \\
\hline Mean & 41.3 & - & 34.3 & 30.0 & - & 49.7 & - \\
\hline \multicolumn{8}{|c|}{ Year 2: Fall 2015} \\
\hline $\mathrm{N}$ & 2 & 1 & 2 & 1 & 1 & 0 & 0 \\
\hline Min & 35 & 66 & 45 & 43 & 95 & - & - \\
\hline $\operatorname{Max}$ & 40 & 66 & 47 & 43 & 95 & - & - \\
\hline Mean & 37.5 & 66.0 & 46.0 & 43.0 & 95.0 & - & - \\
\hline \multicolumn{8}{|c|}{ Year 2: Spring 2016} \\
\hline $\mathrm{N}$ & 4 & 0 & 12 & 0 & 3 & 1 & 0 \\
\hline Min & 35 & - & 30 & - & 70 & 41 & - \\
\hline $\operatorname{Max}$ & 55 & - & 48 & - & 122 & 41 & - \\
\hline Mean & 48.0 & - & 38.3 & - & 95.7 & 41.0 & - \\
\hline \multicolumn{8}{|c|}{ Year 3: Fall 2016} \\
\hline $\mathrm{N}$ & 4 & 0 & 7 & 7 & 5 & 1 & 1 \\
\hline Min & 40 & - & 29 & 42 & 88 & 20 & 54 \\
\hline Max & 53 & - & 39 & 96 & 170 & 20 & 54 \\
\hline Mean & 47.5 & - & 33.9 & 63.4 & 117.0 & 20.0 & 54.0 \\
\hline \multicolumn{8}{|c|}{ Year 3: Spring 2017} \\
\hline $\mathrm{N}$ & 1 & 0 & 3 & 1 & 6 & 9 & 2 \\
\hline Min & 64 & - & 38 & 50 & 68 & 21 & 65 \\
\hline Max & 64 & - & 61 & 50 & 125 & 49 & 66 \\
\hline Mean & 64.0 & - & 46.7 & 50.0 & 96.7 & 39.9 & 65.5 \\
\hline \multicolumn{8}{|c|}{ Year 4: Fall 2017} \\
\hline $\mathrm{N}$ & 2 & 0 & 6 & 39 & 3 & 8 & 0 \\
\hline Min & 46 & - & 39 & 23 & 69 & 25 & - \\
\hline Max & 71 & - & 54 & 89 & 96 & 50 & - \\
\hline Mean & 58.5 & - & 46.0 & 55.7 & 84.0 & 32.9 & - \\
\hline \multicolumn{8}{|c|}{ Year 4: Spring 2018} \\
\hline $\mathrm{N}$ & 2 & 0 & 25 & 58 & 8 & 9 & 5 \\
\hline Min & 38 & - & 30 & 35 & 45 & 8 & 50 \\
\hline $\operatorname{Max}$ & 41 & - & 52 & 92 & 138 & 46 & 110 \\
\hline Mean & 39.5 & - & 39.7 & 52.6 & 99.8 & 34.3 & 84.4 \\
\hline
\end{tabular}


Table 17. Sizes of invertebrates measured on swaths at West End in fall 2014 through spring 2019.-Continued

[Strongylocentrotus spp. excluded. See figures 25 and 26 for purple and red urchin size data. Abbreviations: N, sample size; Min, minimum; -, no data; Max, maximum]

\begin{tabular}{|c|c|c|c|c|c|c|c|}
\hline \multirow[b]{2}{*}{ Size } & \multicolumn{7}{|c|}{ Species name } \\
\hline & $\begin{array}{c}\text { Crassadoma } \\
\text { gigantea }\end{array}$ & $\begin{array}{c}\text { Haliotis } \\
\text { rufescens }\end{array}$ & $\begin{array}{r}\text { Kelletia } \\
\text { kelletii }\end{array}$ & $\begin{array}{c}\text { Megastraea } \\
\text { undosa }\end{array}$ & $\begin{array}{c}\text { Megathura } \\
\text { crenulata }\end{array}$ & $\begin{array}{c}\text { Patiria } \\
\text { miniata }\end{array}$ & $\begin{array}{c}\text { Pisaster } \\
\text { giganteus }\end{array}$ \\
\hline \multicolumn{8}{|c|}{ Year 5: Fall 2018} \\
\hline $\mathrm{N}$ & 0 & 0 & 9 & 99 & 5 & 11 & 2 \\
\hline Min & - & - & 42 & 30 & 100 & 30 & 111 \\
\hline Max & - & - & 60 & 90 & 140 & 65 & 130 \\
\hline Mean & - & - & 51.1 & 57.0 & 118.4 & 49.8 & 120.5 \\
\hline \multicolumn{8}{|c|}{ Year 5: Spring 2019} \\
\hline $\mathrm{N}$ & 9 & 0 & 26 & 116 & 2 & 8 & 0 \\
\hline Min & 40 & - & 27 & 21 & 72 & 40 & - \\
\hline Max & 71 & - & 53 & 93 & 106 & 55 & 一 \\
\hline Mean & 50.6 & - & 39.5 & 55.2 & 89.0 & 49.4 & 一 \\
\hline
\end{tabular}


Strongylocentrotus purpuratus - West End
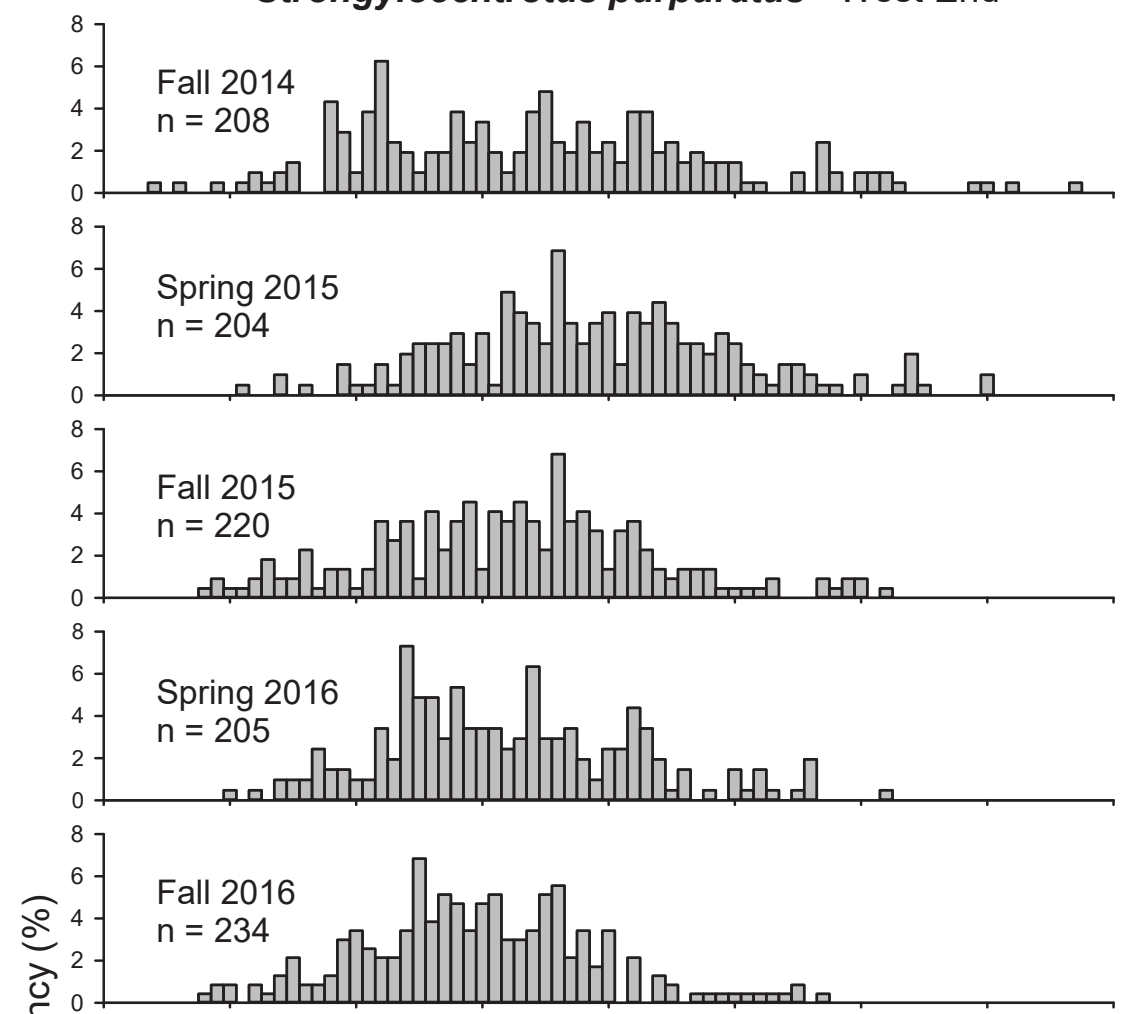

○े

힌
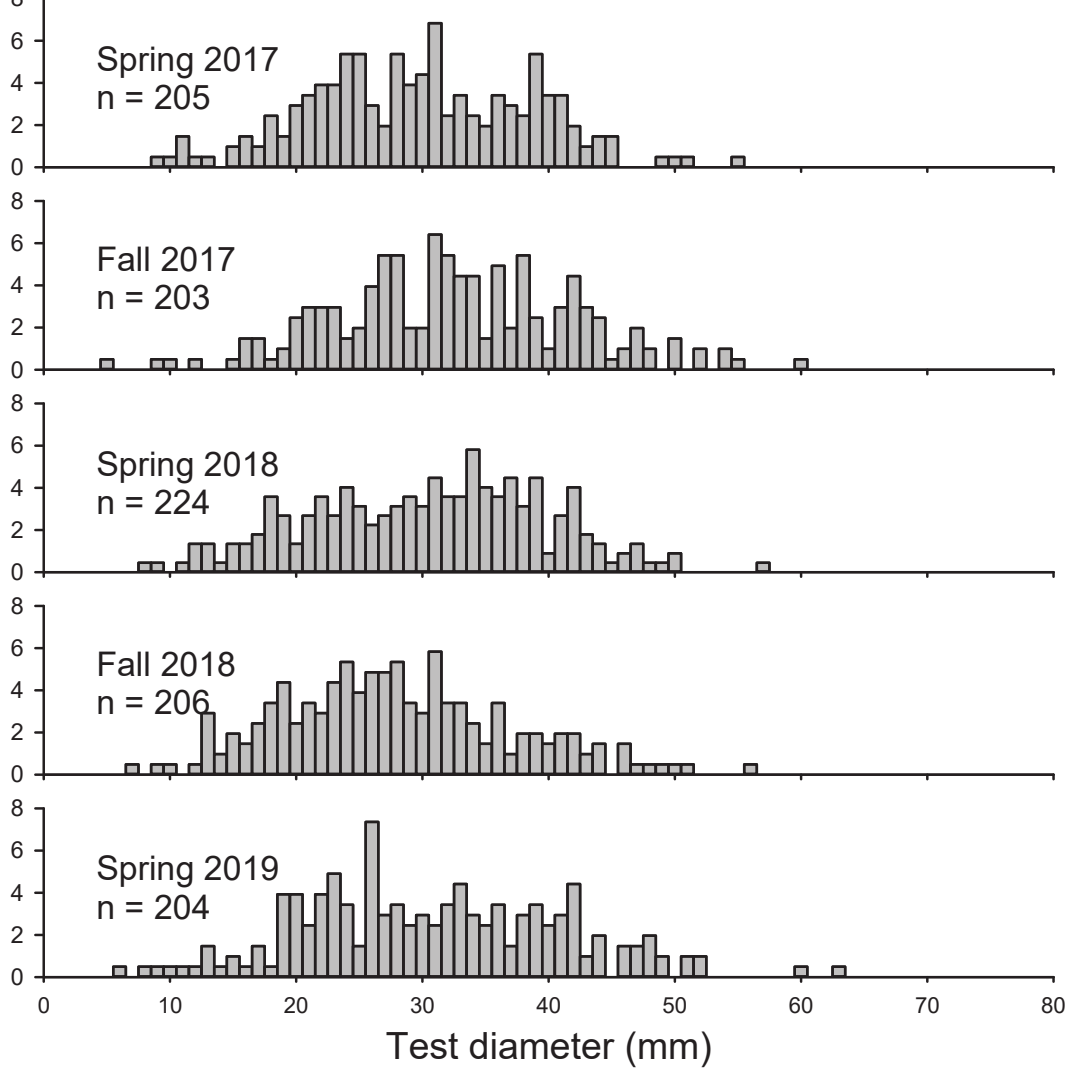

Figure 25. West End size structure of purple urchins (Strongylocentrotus purpuratus) in fall 2014-spring 2019. [ $n=$ number of individuals] 
Strongylocentrotus franciscanus - West End
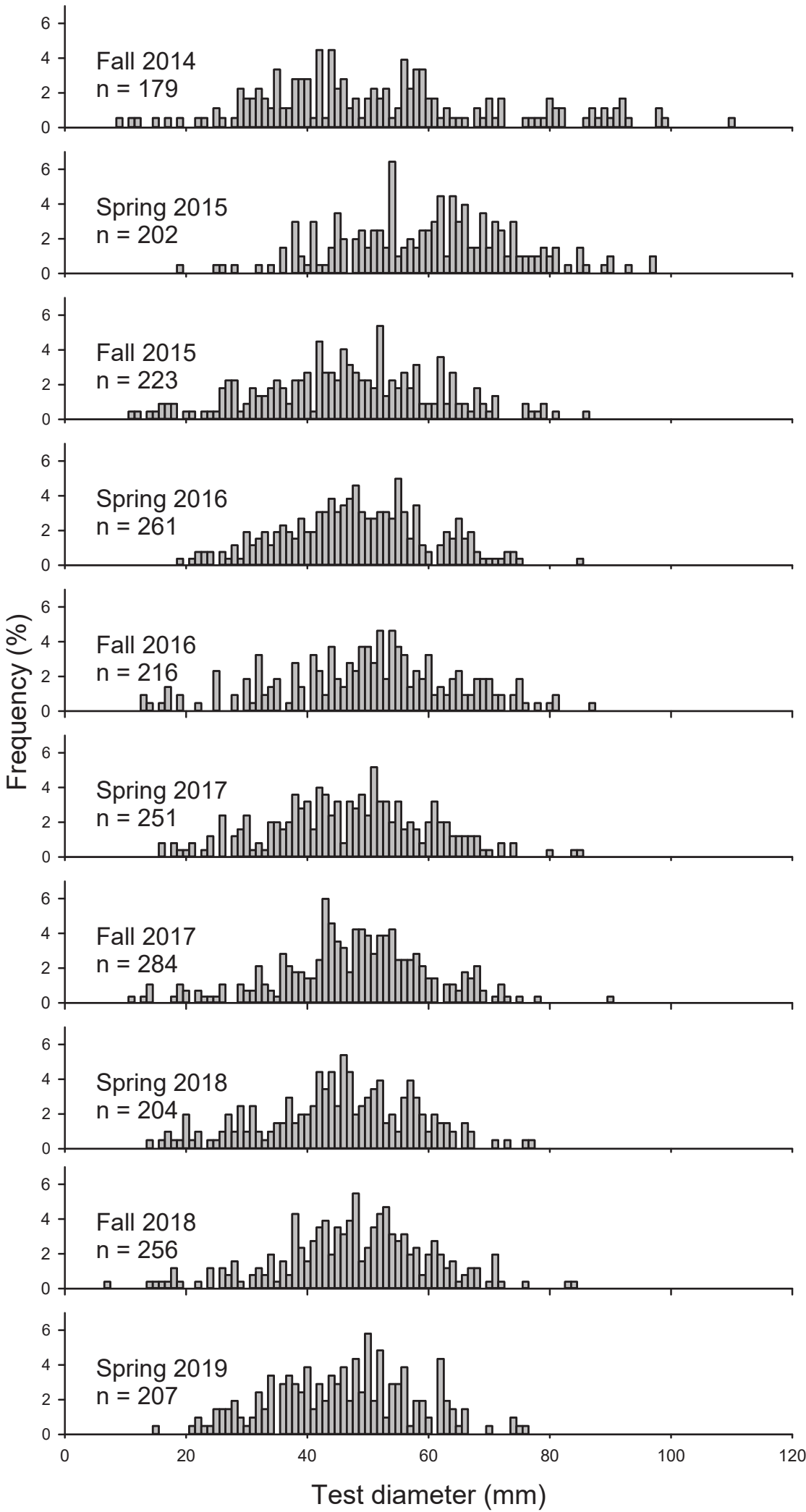

Figure 26. West End size structure of red urchins (Strongylocentrotus franciscanus) in fall 2014-spring 2019. [ $\mathrm{n}=$ number of individuals] 
Table 18. Mean (and standard deviation) numbers of rare species counted on twenty 1-square meter quadrats from West End, fall 2014 through spring 2019.

\begin{tabular}{|c|c|c|c|c|c|c|c|c|c|c|}
\hline Species name & $\begin{array}{l}\text { Fall } \\
2014\end{array}$ & $\begin{array}{c}\text { Spring } \\
2015\end{array}$ & $\begin{array}{l}\text { Fall } \\
2015\end{array}$ & $\begin{array}{c}\text { Spring } \\
2016\end{array}$ & $\begin{array}{c}\text { Fall } \\
2016\end{array}$ & $\begin{array}{c}\text { Spring } \\
2017\end{array}$ & $\begin{array}{l}\text { Fall } \\
2017\end{array}$ & $\begin{array}{c}\text { Spring } \\
2018\end{array}$ & $\begin{array}{l}\text { Fall } \\
2018\end{array}$ & $\begin{array}{c}\text { Spring } \\
2019\end{array}$ \\
\hline Lithopoma gibberosa & $\begin{array}{c}0.0 \\
(0.00)\end{array}$ & $\begin{array}{c}0.0 \\
(0.00)\end{array}$ & $\begin{array}{c}0.1 \\
(0.31)\end{array}$ & $\begin{array}{c}0.0 \\
(0.00)\end{array}$ & $\begin{array}{c}0.1 \\
(0.22)\end{array}$ & $\begin{array}{c}0.0 \\
(0.00)\end{array}$ & $\begin{array}{c}0.0 \\
(0.00)\end{array}$ & $\begin{array}{c}0.0 \\
(0.00)\end{array}$ & $\begin{array}{c}0.1 \\
(0.22)\end{array}$ & $\begin{array}{c}0.0 \\
(0.00)\end{array}$ \\
\hline Cypraea spadicea & $\begin{array}{c}0.1 \\
(0.22)\end{array}$ & $\begin{array}{c}0.0 \\
(0.00)\end{array}$ & $\begin{array}{c}0.0 \\
(0.00)\end{array}$ & $\begin{array}{c}0.1 \\
(0.22)\end{array}$ & $\begin{array}{c}0.0 \\
(0.00)\end{array}$ & $\begin{array}{c}0.0 \\
(0.00)\end{array}$ & $\begin{array}{c}0.0 \\
(0.00)\end{array}$ & $\begin{array}{c}0.0 \\
(0.00)\end{array}$ & $\begin{array}{c}0.0 \\
(0.00)\end{array}$ & $\begin{array}{c}0.0 \\
(0.00)\end{array}$ \\
\hline Kelletia kelletii & $\begin{array}{c}0.0 \\
(0.00)\end{array}$ & $\begin{array}{c}0.1 \\
(0.22)\end{array}$ & $\begin{array}{c}0.1 \\
(0.22)\end{array}$ & $\begin{array}{c}0.0 \\
(0.00)\end{array}$ & $\begin{array}{c}0.1 \\
(0.22)\end{array}$ & $\begin{array}{c}0.0 \\
(0.00)\end{array}$ & $\begin{array}{c}0.0 \\
(0.00)\end{array}$ & $\begin{array}{c}0.0 \\
(0.00)\end{array}$ & $\begin{array}{c}0.0 \\
(0.00)\end{array}$ & $\begin{array}{c}0.0 \\
(0.00)\end{array}$ \\
\hline Norrisia norrisi & $\begin{array}{c}0.0 \\
(0.00)\end{array}$ & $\begin{array}{c}0.1 \\
(0.22)\end{array}$ & $\begin{array}{c}0.0 \\
(0.00)\end{array}$ & $\begin{array}{c}0.0 \\
(0.00)\end{array}$ & $\begin{array}{c}0.2 \\
(0.37)\end{array}$ & $\begin{array}{c}0.1 \\
(0.31)\end{array}$ & $\begin{array}{c}0.1 \\
(0.22)\end{array}$ & $\begin{array}{c}0.1 \\
(0.22)\end{array}$ & $\begin{array}{c}0.2 \\
(0.49)\end{array}$ & $\begin{array}{c}0.1 \\
(0.31)\end{array}$ \\
\hline Sargassum horneri & $\begin{array}{c}0.0 \\
(0.00)\end{array}$ & $\begin{array}{c}0.0 \\
(0.00)\end{array}$ & $\begin{array}{c}0.0 \\
(0.00)\end{array}$ & $\begin{array}{c}0.0 \\
(0.00)\end{array}$ & $\begin{array}{c}0.0 \\
(0.00)\end{array}$ & $\begin{array}{c}0.0 \\
(0.00)\end{array}$ & $\begin{array}{c}0.0 \\
(0.00)\end{array}$ & $\begin{array}{c}0.0 \\
(0.00)\end{array}$ & $\begin{array}{c}0.0 \\
(0.00)\end{array}$ & $\begin{array}{c}0.0 \\
(0.00)\end{array}$ \\
\hline Styela montereyensis & $\begin{array}{c}0.2 \\
(0.41)\end{array}$ & $\begin{array}{c}0.3 \\
(0.55)\end{array}$ & $\begin{array}{c}0.1 \\
(0.31)\end{array}$ & $\begin{array}{c}0.1 \\
(0.22)\end{array}$ & $\begin{array}{c}0.2 \\
(0.52)\end{array}$ & $\begin{array}{c}0.1 \\
(0.31)\end{array}$ & $\begin{array}{c}0.3 \\
(0.73)\end{array}$ & $\begin{array}{c}0.2 \\
(0.37)\end{array}$ & $\begin{array}{c}0.1 \\
(0.22)\end{array}$ & $\begin{array}{c}0.2 \\
(0.49)\end{array}$ \\
\hline Tegula regina & $\begin{array}{c}0.0 \\
(0.00)\end{array}$ & $\begin{array}{c}0.0 \\
(0.00)\end{array}$ & $\begin{array}{c}0.0 \\
(0.00)\end{array}$ & $\begin{array}{c}0.0 \\
(0.00)\end{array}$ & $\begin{array}{c}0.0 \\
(0.00)\end{array}$ & $\begin{array}{c}0.0 \\
(0.00)\end{array}$ & $\begin{array}{c}0.0 \\
(0.00)\end{array}$ & $\begin{array}{c}0.0 \\
(0.00)\end{array}$ & $\begin{array}{c}0.0 \\
(0.00)\end{array}$ & $\begin{array}{c}0.0 \\
(0.00)\end{array}$ \\
\hline Tethya aurantia & $\begin{array}{c}0.2 \\
(0.37)\end{array}$ & $\begin{array}{c}0.1 \\
(0.22)\end{array}$ & $\begin{array}{c}0.1 \\
(0.31)\end{array}$ & $\begin{array}{c}0.1 \\
(0.22)\end{array}$ & $\begin{array}{c}0.1 \\
(0.31)\end{array}$ & $\begin{array}{c}0.1 \\
(0.31)\end{array}$ & $\begin{array}{c}0.1 \\
(0.31)\end{array}$ & $\begin{array}{c}0.1 \\
(0.31)\end{array}$ & $\begin{array}{c}0.1 \\
(0.31)\end{array}$ & $\begin{array}{c}0.1 \\
(0.31)\end{array}$ \\
\hline Tealia lofotensis & $\begin{array}{c}0.0 \\
(0.00)\end{array}$ & $\begin{array}{c}0.0 \\
(0.00)\end{array}$ & $\begin{array}{c}0.0 \\
(0.00)\end{array}$ & $\begin{array}{c}0.0 \\
(0.00)\end{array}$ & $\begin{array}{c}0.0 \\
(0.00)\end{array}$ & $\begin{array}{c}0.0 \\
(0.00)\end{array}$ & $\begin{array}{c}0.0 \\
(0.00)\end{array}$ & $\begin{array}{c}0.0 \\
(0.00)\end{array}$ & $\begin{array}{c}0.0 \\
(0.00)\end{array}$ & $\begin{array}{c}0.0 \\
(0.00)\end{array}$ \\
\hline
\end{tabular}


Table 19. West End point contact "species" ranked by the sum of points for fall 2014 through spring 2019.

[>, greater than; m, meter; $<$, less than]

\begin{tabular}{|c|c|c|c|c|c|c|c|c|c|c|}
\hline Species name & $\begin{array}{l}\text { Fall } \\
2014\end{array}$ & $\begin{array}{c}\text { Spring } \\
2015\end{array}$ & $\begin{array}{l}\text { Fall } \\
2015\end{array}$ & $\begin{array}{c}\text { Spring } \\
2016\end{array}$ & $\begin{array}{l}\text { Fall } \\
2016\end{array}$ & $\begin{array}{c}\text { Spring } \\
2017\end{array}$ & $\begin{array}{l}\text { Fall } \\
2017\end{array}$ & $\begin{array}{c}\text { Spring } \\
2018\end{array}$ & $\begin{array}{l}\text { Fall } \\
2018\end{array}$ & $\begin{array}{c}\text { Spring } \\
2019\end{array}$ \\
\hline Encrusting coralline algae & 267 & 257 & 249 & 125 & 257 & 140 & 196 & 203 & 168 & 221 \\
\hline Calliarthron spp. & 48 & 59 & 67 & 65 & 49 & 69 & 58 & 57 & 55 & 58 \\
\hline Laminaria spp. & 102 & 67 & 60 & 57 & 56 & 88 & 28 & 20 & 25 & 48 \\
\hline Rhodymenia californica & 83 & 47 & 41 & 67 & 73 & 68 & 30 & 31 & 15 & 5 \\
\hline Cystoseira osmundacea & 38 & 52 & 39 & 51 & 46 & 58 & 32 & 43 & 22 & 38 \\
\hline Pterygophora californica & 89 & 51 & 45 & 25 & 26 & 29 & 21 & 28 & 23 & 30 \\
\hline Dictyota binghamiae & 4 & 4 & 2 & 67 & 21 & 58 & 36 & 49 & 45 & 44 \\
\hline Sand & 41 & 25 & 21 & 26 & 35 & 49 & 40 & 17 & 59 & 9 \\
\hline Encrusting red algae & 9 & 20 & 29 & 10 & 15 & 18 & 25 & 53 & 47 & 41 \\
\hline Cryptopleura spp. & 43 & 10 & 21 & 69 & 4 & 40 & 9 & 25 & 4 & 19 \\
\hline Kelp holdfast & 21 & 8 & 15 & 10 & 15 & 19 & 27 & 20 & 28 & 10 \\
\hline Macrocystis pyrifera $<1 \mathrm{~m}$ & 3 & 5 & 5 & 71 & 2 & 31 & 2 & 1 & 23 & 11 \\
\hline Gigartina [Chondracanthus] exasperate & 32 & 24 & 13 & 17 & 17 & 14 & 8 & 3 & 1 & 1 \\
\hline Bare substratum & 8 & 17 & 15 & 1 & 25 & 5 & 28 & 8 & 8 & 9 \\
\hline Pink encrusting bryozoan & 13 & 10 & 28 & 4 & 19 & 10 & 14 & 12 & 12 & 0 \\
\hline Macrocystis pyrifera $>1 \mathrm{~m}$ & 12 & 3 & 6 & 8 & 16 & 15 & 20 & 11 & 10 & 4 \\
\hline Nienburgia andersoniana & 3 & 27 & 5 & 43 & 0 & 23 & 0 & 1 & 1 & 0 \\
\hline Prionitis lanceolata & 7 & 16 & 9 & 13 & 11 & 6 & 16 & 4 & 13 & 8 \\
\hline Gelidium robustum & 15 & 20 & 10 & 7 & 5 & 6 & 7 & 7 & 7 & 9 \\
\hline Phragmatopoma californica & 0 & 0 & 2 & 1 & 3 & 1 & 31 & 11 & 11 & 12 \\
\hline Young Laminariales & 0 & 0 & 0 & 6 & 4 & 21 & 1 & 3 & 2 & 4 \\
\hline Botryocladia pseudodichotoma & 2 & 0 & 1 & 2 & 2 & 11 & 5 & 5 & 6 & 5 \\
\hline Cryptopleura ruprechtiana & 16 & 12 & 0 & 6 & 0 & 3 & 0 & 0 & 0 & 0 \\
\hline Serpulorbis squamiger & 2 & 0 & 3 & 1 & 1 & 1 & 5 & 8 & 8 & 6 \\
\hline Bossiella spp. & 3 & 4 & 1 & 0 & 0 & 6 & 1 & 5 & 4 & 8 \\
\hline Eisenia arborea & 2 & 8 & 1 & 4 & 7 & 0 & 4 & 0 & 5 & 0 \\
\hline Pterosiphonia spp. & 0 & 2 & 3 & 0 & 0 & 7 & 0 & 4 & 0 & 14 \\
\hline Metandrocarpa dura & 2 & 2 & 0 & 3 & 5 & 0 & 9 & 0 & 5 & 2 \\
\hline Neoptilota $[$ Ptilota $]$ densa & 6 & 2 & 1 & 7 & 1 & 1 & 2 & 0 & 0 & 0 \\
\hline Corallina officinalis & 1 & 2 & 0 & 3 & 3 & 0 & 1 & 1 & 3 & 5 \\
\hline Plocamium pacificum & 2 & 2 & 1 & 2 & 1 & 2 & 0 & 1 & 2 & 5 \\
\hline Callophyllis flabellulata & 0 & 0 & 0 & 0 & 7 & 8 & 0 & 0 & 0 & 0 \\
\hline Kallymenia pacifica & 3 & 0 & 2 & 1 & 1 & 1 & 0 & 2 & 3 & 1 \\
\hline Orange encrusting sponge & 4 & 2 & 1 & 0 & 2 & 0 & 3 & 0 & 1 & 0 \\
\hline Didemnum carnulentum & 1 & 2 & 1 & 0 & 2 & 0 & 4 & 1 & 0 & 0 \\
\hline Unidentified sponge & 1 & 5 & 2 & 0 & 0 & 0 & 1 & 1 & 0 & 0 \\
\hline Acanthacora cyanocrypta & 1 & 0 & 7 & 0 & 0 & 0 & 0 & 1 & 0 & 0 \\
\hline Anthopleura sola & 1 & 2 & 0 & 1 & 0 & 2 & 1 & 1 & 0 & 0 \\
\hline Synoicum spp. & 0 & 0 & 0 & 0 & 0 & 0 & 0 & 8 & 0 & 0 \\
\hline Aglaophenia spp. & 0 & 0 & 0 & 2 & 0 & 5 & 0 & 0 & 0 & 0 \\
\hline Barnacle & 0 & 0 & 7 & 0 & 0 & 0 & 0 & 0 & 0 & 0 \\
\hline Dictyopteris undulata & 0 & 0 & 0 & 0 & 3 & 0 & 0 & 0 & 3 & 1 \\
\hline
\end{tabular}


Table 19. West End point contact "species" ranked by the sum of points for fall 2014 through spring 2019._- Continued

$[>$, greater than; $\mathrm{m}$, meter; $<$, less than $]$

\begin{tabular}{|c|c|c|c|c|c|c|c|c|c|c|}
\hline Species name & Fall 2014 & $\begin{array}{c}\text { Spring } \\
2015\end{array}$ & Fall 2015 & $\begin{array}{c}\text { Spring } \\
2016\end{array}$ & Fall 2016 & $\begin{array}{c}\text { Spring } \\
2017\end{array}$ & Fall 2017 & $\begin{array}{c}\text { Spring } \\
2018\end{array}$ & Fall 2018 & $\begin{array}{c}\text { Spring } \\
2019\end{array}$ \\
\hline Filamentous red algae & 3 & 2 & 0 & 0 & 0 & 0 & 1 & 0 & 1 & 0 \\
\hline Laurencia pacifica & 0 & 2 & 0 & 1 & 0 & 2 & 1 & 0 & 0 & 1 \\
\hline Opuntiella californica & 0 & 2 & 0 & 0 & 1 & 0 & 2 & 0 & 2 & 0 \\
\hline Epiactis prolifera & 0 & 0 & 2 & 0 & 0 & 0 & 2 & 0 & 1 & 0 \\
\hline Balanophyllia elegans & 0 & 1 & 0 & 1 & 0 & 0 & 0 & 1 & 0 & 1 \\
\hline Bryopsis corticulans & 0 & 0 & 0 & 0 & 0 & 0 & 0 & 2 & 0 & 2 \\
\hline Polyneura spp. & 0 & 1 & 0 & 3 & 0 & 0 & 0 & 0 & 0 & 0 \\
\hline Tethya aurantia & 1 & 0 & 0 & 1 & 0 & 0 & 0 & 1 & 0 & 0 \\
\hline Crisia spp. & 0 & 0 & 1 & 0 & 0 & 0 & 0 & 1 & 0 & 0 \\
\hline Desmarestia ligulata & 0 & 0 & 0 & 1 & 0 & 1 & 0 & 0 & 0 & 0 \\
\hline Diopatra ornata & 0 & 1 & 0 & 0 & 0 & 0 & 1 & 0 & 0 & 0 \\
\hline Dodecaceria spp. & 0 & 0 & 1 & 0 & 0 & 0 & 1 & 0 & 0 & 0 \\
\hline Pikea spp. & 0 & 1 & 1 & 0 & 0 & 0 & 0 & 0 & 0 & 0 \\
\hline Red algae & 0 & 0 & 0 & 2 & 0 & 0 & 0 & 0 & 0 & 0 \\
\hline Styela montereyensis & 1 & 1 & 0 & 0 & 0 & 0 & 0 & 0 & 0 & 0 \\
\hline Archidistoma psammion & 0 & 0 & 0 & 0 & 1 & 0 & 0 & 0 & 0 & 0 \\
\hline Corynactis californica & 1 & 0 & 0 & 0 & 0 & 0 & 0 & 0 & 0 & 0 \\
\hline Eupentacta quinquesemita & 0 & 0 & 0 & 0 & 0 & 1 & 0 & 0 & 0 & 0 \\
\hline Fauchea $[$ Gloiocladia] laciniata & 0 & 0 & 0 & 0 & 0 & 1 & 0 & 0 & 0 & 0 \\
\hline Laurencia spp. & 0 & 0 & 0 & 0 & 0 & 1 & 0 & 0 & 0 & 0 \\
\hline Leucosolenia eleanor & 0 & 0 & 0 & 0 & 0 & 0 & 1 & 0 & 0 & 0 \\
\hline Pachythyone rubra & 0 & 0 & 0 & 0 & 0 & 0 & 1 & 0 & 0 & 0 \\
\hline Pholad clam & 0 & 0 & 0 & 0 & 0 & 0 & 0 & 0 & 1 & 0 \\
\hline Polyclinum planum & 0 & 0 & 1 & 0 & 0 & 0 & 0 & 0 & 0 & 0 \\
\hline Prionitis spp. & 0 & 0 & 0 & 0 & 0 & 1 & 0 & 0 & 0 & 0 \\
\hline Red algal turf & 0 & 0 & 0 & 1 & 0 & 0 & 0 & 0 & 0 & 0 \\
\hline Stylantheca porphyra & 0 & 0 & 0 & 0 & 1 & 0 & 0 & 0 & 0 & 0 \\
\hline
\end{tabular}


Table 20. West End fish counts_adult (juvenile)—in fall 2014 through spring 2019 (by species).

[f, female; $\mathrm{m}$, male]

\begin{tabular}{|c|c|c|c|c|c|c|c|c|c|c|}
\hline Species name & $\begin{array}{l}\text { Fall } \\
2014\end{array}$ & $\begin{array}{c}\text { Spring } \\
2015\end{array}$ & $\begin{array}{l}\text { Fall } \\
2015\end{array}$ & $\begin{array}{c}\text { Spring } \\
2016\end{array}$ & $\begin{array}{l}\text { Fall } \\
2016\end{array}$ & $\begin{array}{c}\text { Spring } \\
2017\end{array}$ & $\begin{array}{l}\text { Fall } \\
2017\end{array}$ & $\begin{array}{c}\text { Spring } \\
2018\end{array}$ & $\begin{array}{l}\text { Fall } \\
2018\end{array}$ & $\begin{array}{c}\text { Spring } \\
2019\end{array}$ \\
\hline Artedius spp. & 0 & 0 & 1 & 1 & 0 & 0 & 0 & 0 & 0 & 0 \\
\hline Brachyistius frenatus & 40 & 6 & 1 & 0 & 29 & 1 & 1 & 1 & 6 & 3 \\
\hline Chromis punctipinnis & 1,030 & $305(27)$ & 788 & 214 & 385 & 232 & 26 & 168 & 98 & 47 \\
\hline Rhinogobiops nicholsii & 2 & 0 & 1 & 0 & 0 & 0 & 0 & 0 & 0 & 0 \\
\hline Embiotoca jacksoni & 43 & 6 & 17 & 10 & 36 & 17 & 33 & 37 & 21 & 26 \\
\hline Embiotoca lateralis & 61 & 7 & 7 & 1 & 10 & 5 & 4 & 7 & 8 & 5 \\
\hline Gibbonsia spp. & 3 & 0 & 0 & 0 & 0 & 0 & 0 & 0 & 0 & 0 \\
\hline Girella nigricans & 7 & 1 & 3 & 5 & 7 & 9 & 6 & 1 & 34 & 2 \\
\hline Gymnothorax mordax & 0 & 0 & 0 & 1 & 0 & 0 & 0 & 0 & 0 & 0 \\
\hline Halichoeres semicinctus & 0 & 0 & 0 & 0 & 0 & 0 & 0 & 1 & 0 & 0 \\
\hline Heterostichus rostratus & 1 & 0 & 0 & 0 & 0 & 0 & 0 & 0 & 0 & 0 \\
\hline Hypsurus caryi & 6 & 0 & 2 & 3 & 8 & 0 & 7 & 3 & 0 & 0 \\
\hline Hypsypops rubicundus & 1 & 0 & 0 & 0 & 3 & 3 & 1 & 5 & 1 & 4 \\
\hline Medialuna californiensis & 0 & 0 & 1 & 2 & 0 & 0 & 0 & 3 & 2 & 1 \\
\hline Myliobatis californica & 0 & 0 & 0 & 0 & 0 & 0 & 0 & 0 & 1 & 0 \\
\hline Neoclinus spp. & 0 & 0 & 0 & 0 & 0 & 0 & 1 & 0 & 0 & 0 \\
\hline Ophiodon elongatus & 0 & 0 & 0 & 0 & 0 & 1 & 0 & 0 & 0 & 0 \\
\hline Oxyjulis californica & 2,613 & 286 & 1,751 & 1,146 & 529 & 792 & 159 & 305 & 277 & 171 \\
\hline Oxylebius pictus & 8 & 8 & 10 & 7 & 1 & 5 & 1 & 2 & 4 & 2 \\
\hline Paralabrax clathratus & 11 & $2(2)$ & $22(3)$ & 5 & 15 & 18 & 3 & 5 & 14 & 11 \\
\hline Rhacochilus toxotes & 0 & 0 & 0 & 0 & 2 & 0 & 0 & 0 & 0 & 0 \\
\hline Rhacochilus vacca & 4 & 1 & 0 & 1 & 1 & 0 & 1 & 0 & 0 & 0 \\
\hline Scorpaenichthys marmoratus & 0 & 1 & 0 & 0 & 0 & 0 & 0 & 0 & 0 & 0 \\
\hline Sebastes atrovirens & 16 & 1 & 7 & 0 & 3 & 3 & 4 & 1 & 1 & 2 \\
\hline Sebastes auriculatus & 0 & 0 & 0 & 1 & 0 & 0 & 1 & 0 & 0 & 0 \\
\hline Sebastes carnatus & 0 & 0 & 0 & 0 & 0 & 2 & 0 & 0 & 0 & 0 \\
\hline Sebastes caurinus & 0 & 0 & 0 & 0 & 0 & $0(1)$ & 0 & 0 & 0 & 0 \\
\hline Sebastes chrysomelas & 12 & 0 & 9 & 4 & 1 & 1 & 1 & 0 & 0 & 0 \\
\hline Sebastes mystinus & 126 & $278(12)$ & 14 & 21 & 123 & 59 & 33 & 60 & 17 & 24 \\
\hline Sebastes rastrelliger & 2 & 0 & 0 & 0 & 1 & 0 & 0 & 2 & 0 & 1 \\
\hline Sebastes serranoides & 0 & 0 & 4 & 10 & $48(25)$ & 4 & 2 & 6 & 1 & 7 \\
\hline Sebastes serriceps & 1 & 0 & 0 & 0 & 0 & 0 & 0 & 0 & 0 & 0 \\
\hline Sebastes spp. & 0 & 0 & 0 & 0 & 0 & $0(1)$ & 0 & 0 & 0 & 0 \\
\hline Semicossyphus pulcher (f) & 20 & $10(2)$ & 32 & 15 & 20 & 28 & 16 & 31 & 28 & 29 \\
\hline Semicossyphus pulcher (m) & 13 & 3 & 4 & 0 & 6 & 11 & 3 & 15 & 10 & 4 \\
\hline Stereolepis gigas & 1 & 0 & 0 & 0 & 0 & 0 & 0 & 0 & 0 & 0 \\
\hline Torpedo californica & 1 & 0 & 0 & 0 & 0 & 0 & 0 & 0 & 0 & 0 \\
\hline
\end{tabular}




\section{Dutch Harbor}

Figure 27 shows mean counts of some of the most dynamic species that were counted on the swaths at the Dutch Harbor supersite during the last 5 years. Both purple and red sea urchins, which had doubled in density between 2017 and 2018 , leveled off with the latter species reaching 14.5 percent of the former. The rock scallop ( $C$. gigantea) followed a similar trend in recent years, increasing substantially in 2017 and then leveling off. Like at West End, the wavy turban snail (M. undosa) increased from near zero in the last 2 years and, at Dutch Harbor, its density has approximately doubled in each of the last four sampling trips. Juvenile $M$. pyrifera showed two sizeable recruitments in the last 5 years with peaks in fall 2016 and spring 2019. Only the earlier peak corresponded to a jump in the density of plants greater than $1 \mathrm{~m}$, however.

Purple urchins, followed by red urchins, remained the most common swath-counted organism at Dutch Harbor (table 21). The spotted rose anemone, T. lofotensis, was third. Laminaria spp. was the most common kelp except in the last period when juvenile $M$. pyrifera recruited.

Figures 28 and 29 show the stipe counts and holdfast diameters of $M$. pyrifera throughout the last 10 sampling periods at Dutch Harbor. In contrast to West End, Dutch Harbor showed no recruitment pulse in the "adult" population in year 5 . There were only 2 plants with less than $10-\mathrm{cm}$ holdfast diameter, and the total count of 12 plants in the "adult" Macrocystis population in spring 2019 was the lowest recorded since counts began in 1980. There were, however, a total of 248 juvenile Macrocystis counted on the supersite in spring 2019; this was the second highest recorded in more than 10 years.

Sizes of invertebrates measured on the swaths at Dutch Harbor are summarized in table 22. As mentioned earlier, counts of the rock scallop (C. gigantea) leveled off during the last two sample years, and in year 5, their mean size was only slightly higher than previous sample years. Counts of the wavy turban snail (M. undosa) increased considerably in fall 2018 and again in spring 2019, but their sizes showed little change. Counts of Kellet's whelk ( $K$. kelletii), the giant keyhole limpet (Megathura crenulata), and the sea star, P. miniata, were too low or variable to draw conclusions from the size data.

The size distribution of $S$. purpuratus showed little substantive change in recent years, but there were fewer individuals greater than $60 \mathrm{~mm}$ than in most previous samples (fig. 30). Despite this, Dutch Harbor continued to have the most purple urchins in the largest size bin of all the supersites (table 10). In fall 2017 and spring 2018, red urchins showed an increase in the smaller sizes (fig. 31). By year 5, the increased proportion had been passed on to the middle and large size bins (table 11), and the resulting size frequency plot in spring 2019 looked remarkably similar to that from 2-years earlier.

Tealia lofotensis continued to be relatively stable in density and remained the most common species in the 1- $\mathrm{m}^{2}$ quadrat counts (table 23). The orange puffball sponge (T. aurantia) and the stalked tunicate (S. montereyensis) remained present at lower numbers.

Excluding the bare substrate category, Dutch Harbor RPC quadrats continued to have a relatively even mix of categories of species with encrusting algae and non-motile invertebrates as the most common (fig. 21). This is the only supersite where invertebrates rival encrusting algae as the dominant cover category. There has been a slight decrease in the cover of fleshy red algae during the last 2 years. Of the cover taxa recorded, encrusting coralline algae dominated, followed by $C$. osmundacea, Laminaria spp., and the tube-building polychaete, Diopatra ornata. The small sea cucumbers, Pachythyone rubra and Cucumaria piperata, and pink encrusting bryozoans also were quite common (table 24). More than at any of the other sites, cover here was a diverse mix of algae and invertebrates.

Dutch Harbor continued to have the greatest number of fish species and the highest overall fish density of all sites (table 14). Most fishes encountered at Dutch Harbor were blacksmith (C. punctipinnis) and señorita (O. californica), but a suite of rockfishes, including blue (S. mystinus) and olive rockfish (S. serranoides), as well as sheephead (S. pulcher), were regular members of the overall site assemblage (table 25). No juvenile $S$. pulcher were observed in year 5 because warm-water associated recruitment (Cowen, 1985) came to an end with the switch to cooler ocean conditions in 2016. Many of the fish transects at Dutch Harbor traverse a high relief reef with a multitude of cracks, crevices, and ledges that serve as refuge for a variety of fishes. On most of the west-heading transects, a sharp drop-off and near vertical wall from $6 \mathrm{~m}$ at the reef crest down to $15 \mathrm{~m}$ at the bottom is encountered. The water column above the drop-off is often teeming with high numbers of fish of more than a dozen species; however, the final 10-30 $\mathrm{m}$ at the distal end of these western transects traverse a sand channel that is mostly devoid of fish. The fact that nearly all of the fish recorded are seen on only about one half the lengths of these western transects underscores the incredible productivity of Dutch Harbor's rocky reefs. 


\section{Dynamic swath counted species} mean count / $20 \mathrm{~m}^{2}$ - Dutch Harbor

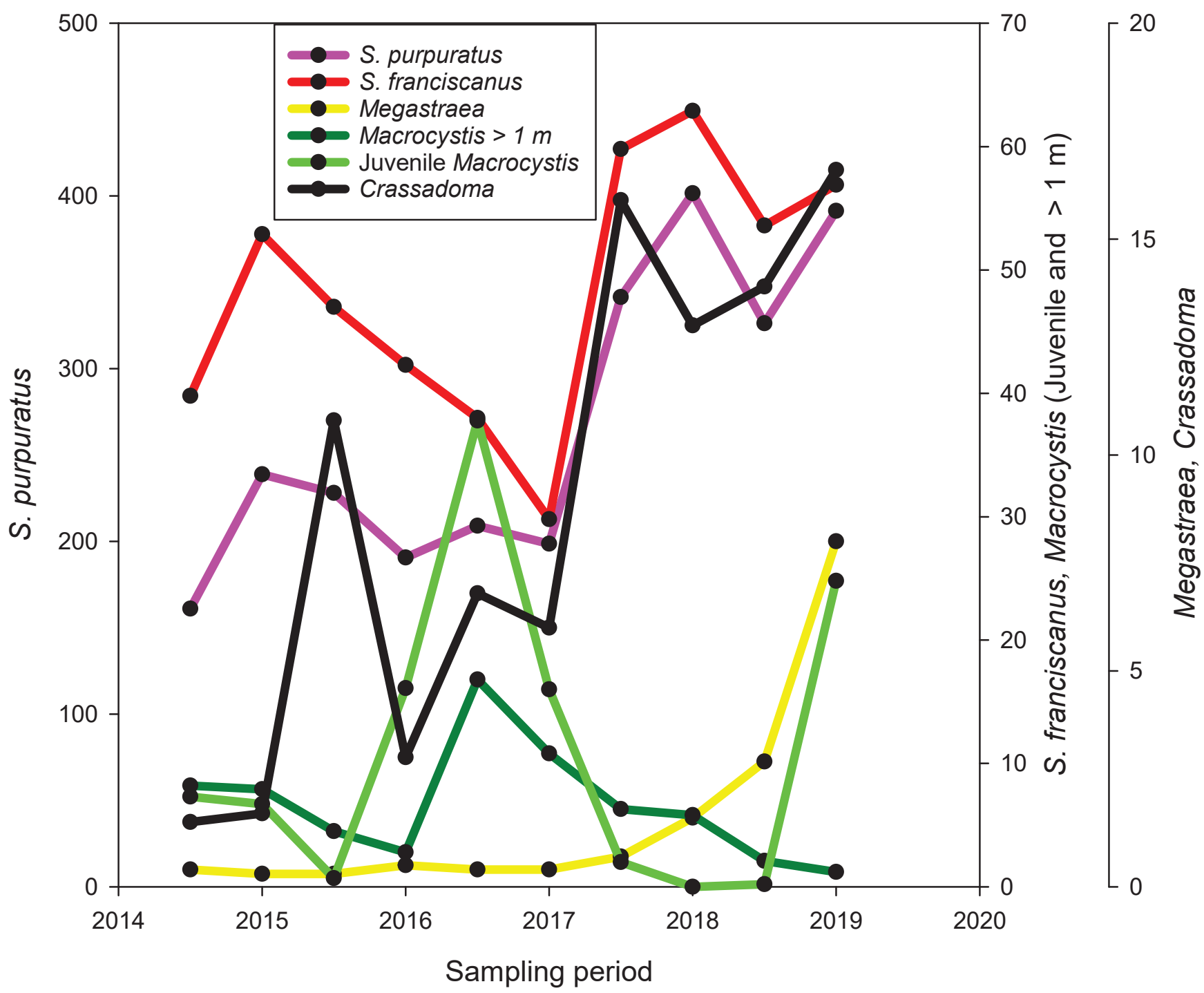

Figure 27. Mean densities of some swath-counted species that have demonstrated changing abundance at Dutch Harbor during the last 5 years. [Note three vertical axes for densities of different species groups]

Table 21. Dutch Harbor mean (standard deviation) swath counts for fall 2014 through spring 2019 expressed as individuals per 20-square meter transect.

$[>$, greater than; $\mathrm{m}$, meter; $<$, less than]

\begin{tabular}{|c|c|c|c|c|c|c|c|c|c|c|}
\hline Species name & $\begin{array}{l}\text { Fall } \\
2014\end{array}$ & $\begin{array}{c}\text { Spring } \\
2015\end{array}$ & $\begin{array}{l}\text { Fall } \\
2015\end{array}$ & $\begin{array}{c}\text { Spring } \\
2016\end{array}$ & $\begin{array}{l}\text { Fall } \\
2016\end{array}$ & $\begin{array}{c}\text { Spring } \\
2017\end{array}$ & $\begin{array}{l}\text { Fall } \\
2017\end{array}$ & $\begin{array}{c}\text { Spring } \\
2018\end{array}$ & $\begin{array}{l}\text { Fall } \\
2018\end{array}$ & $\begin{array}{c}\text { Spring } \\
2019\end{array}$ \\
\hline Aplysia californica & $\begin{array}{c}0 \\
(0.00)\end{array}$ & $\begin{array}{c}0 \\
(0.00)\end{array}$ & $\begin{array}{c}0 \\
(0.00)\end{array}$ & $\begin{array}{c}0 \\
(0.00)\end{array}$ & $\begin{array}{c}0 \\
(0.00)\end{array}$ & $\begin{array}{c}0 \\
(0.00)\end{array}$ & $\begin{array}{c}0 \\
(0.00)\end{array}$ & $\begin{array}{c}0 \\
(0.00)\end{array}$ & $\begin{array}{c}0 \\
(0.00)\end{array}$ & $\begin{array}{c}0 \\
(0.00)\end{array}$ \\
\hline Astrometis sertulifera & $\begin{array}{c}0 \\
(0.00)\end{array}$ & $\begin{array}{c}0 \\
(0.00)\end{array}$ & $\begin{array}{c}0 \\
(0.00)\end{array}$ & $\begin{array}{c}0 \\
(0.00)\end{array}$ & $\begin{array}{c}0 \\
(0.00)\end{array}$ & $\begin{array}{c}0 \\
(0.00)\end{array}$ & $\begin{array}{c}0 \\
(0.00)\end{array}$ & $\begin{array}{c}0 \\
(0.00)\end{array}$ & $\begin{array}{c}0 \\
(0.00)\end{array}$ & $\begin{array}{c}0 \\
(0.00)\end{array}$ \\
\hline Crassadoma gigantea & $\begin{array}{c}1.5 \\
(1.78)\end{array}$ & $\begin{array}{c}1.7 \\
(1.64)\end{array}$ & $\begin{array}{c}10.8 \\
(6.97)\end{array}$ & $\begin{array}{c}3 \\
(2.16)\end{array}$ & $\begin{array}{c}6.8 \\
(5.75)\end{array}$ & $\begin{array}{c}6 \\
(4.83)\end{array}$ & $\begin{array}{c}15.9 \\
(11.15)\end{array}$ & $\begin{array}{c}13 \\
(9.85)\end{array}$ & $\begin{array}{c}13.90 \\
(10.14)\end{array}$ & $\begin{array}{l}16.60 \\
(8.30)\end{array}$ \\
\hline
\end{tabular}


Table 21. Dutch Harbor mean (standard deviation) swath counts for fall 2014 through spring 2019 expressed as individuals per 20-square meter transect.-Continued

$[>$, greater than; $\mathrm{m}$, meter; <, less than]

\begin{tabular}{|c|c|c|c|c|c|c|c|c|c|c|}
\hline Species name & $\begin{array}{l}\text { Fall } \\
2014\end{array}$ & $\begin{array}{c}\text { Spring } \\
2015\end{array}$ & $\begin{array}{l}\text { Fall } \\
2015\end{array}$ & $\begin{array}{c}\text { Spring } \\
2016\end{array}$ & $\begin{array}{l}\text { Fall } \\
2016\end{array}$ & $\begin{array}{c}\text { Spring } \\
2017\end{array}$ & $\begin{array}{l}\text { Fall } \\
2017\end{array}$ & $\begin{array}{c}\text { Spring } \\
2018\end{array}$ & $\begin{array}{l}\text { Fall } \\
2018\end{array}$ & $\begin{array}{c}\text { Spring } \\
2019\end{array}$ \\
\hline Cystoseira osmundacea & $\begin{array}{c}6.8 \\
(9.58)\end{array}$ & $\begin{array}{c}7.7 \\
(9.46)\end{array}$ & $\begin{array}{c}8.2 \\
(6.81)\end{array}$ & $\begin{array}{c}5.5 \\
(8.42)\end{array}$ & $\begin{array}{c}6.9 \\
(7.19)\end{array}$ & $\begin{array}{c}9.8 \\
(11.81)\end{array}$ & $\begin{array}{c}6.6 \\
(7.21)\end{array}$ & $\begin{array}{c}6.7 \\
(11.43)\end{array}$ & $\begin{array}{c}5.90 \\
(8.10)\end{array}$ & $\begin{array}{c}10.30 \\
(12.74)\end{array}$ \\
\hline Dermasterias imbricata & $\begin{array}{c}0 \\
(0.00)\end{array}$ & $\begin{array}{c}0 \\
(0.00)\end{array}$ & $\begin{array}{c}0 \\
(0.00)\end{array}$ & $\begin{array}{c}0.1 \\
(0.32)\end{array}$ & $\begin{array}{c}0 \\
(0.00)\end{array}$ & $\begin{array}{c}0 \\
(0.00)\end{array}$ & $\begin{array}{c}0 \\
(0.00)\end{array}$ & $\begin{array}{c}0 \\
(0.00)\end{array}$ & $\begin{array}{c}0 \\
(0.00)\end{array}$ & $\begin{array}{c}0 \\
(0.00)\end{array}$ \\
\hline Eisenia arborea & $\begin{array}{c}9.7 \\
(8.30)\end{array}$ & $\begin{array}{c}14.7 \\
(10.06)\end{array}$ & $\begin{array}{c}9.7 \\
(8.11)\end{array}$ & $\begin{array}{c}8.9 \\
(5.07)\end{array}$ & $\begin{array}{c}12.4 \\
(9.01)\end{array}$ & $\begin{array}{c}12.7 \\
(7.29)\end{array}$ & $\begin{array}{c}9.1 \\
(10.09)\end{array}$ & $\begin{array}{c}5.8 \\
(5.77)\end{array}$ & $\begin{array}{c}5.40 \\
(6.52)\end{array}$ & $\begin{array}{c}5.10 \\
(5.76)\end{array}$ \\
\hline Haliotis rufescens & $\begin{array}{c}0 \\
(0.00)\end{array}$ & $\begin{array}{c}0 \\
(0.00)\end{array}$ & $\begin{array}{c}0 \\
(0.00)\end{array}$ & $\begin{array}{c}0 \\
(0.00)\end{array}$ & $\begin{array}{c}0 \\
(0.00)\end{array}$ & $\begin{array}{c}0 \\
(0.00)\end{array}$ & $\begin{array}{c}0 \\
(0.00)\end{array}$ & $\begin{array}{c}0 \\
(0.00)\end{array}$ & $\begin{array}{c}0 \\
(0.00)\end{array}$ & $\begin{array}{c}0 \\
(0.00)\end{array}$ \\
\hline Kelletia kelletii & $\begin{array}{c}0.5 \\
(1.58)\end{array}$ & $\begin{array}{c}0.9 \\
(1.29)\end{array}$ & $\begin{array}{c}0.7 \\
(1.57)\end{array}$ & $\begin{array}{c}0.7 \\
(1.06)\end{array}$ & $\begin{array}{c}0.5 \\
(0.85)\end{array}$ & $\begin{array}{c}0 \\
(0.00)\end{array}$ & $\begin{array}{c}0.1 \\
(0.32)\end{array}$ & $\begin{array}{c}2.3 \\
(2.16)\end{array}$ & $\begin{array}{c}0.50 \\
(1.08)\end{array}$ & $\begin{array}{c}2.60 \\
(3.27)\end{array}$ \\
\hline Macrocystis pyrifera $<1 \mathrm{~m}$ & $\begin{array}{c}7.3 \\
(9.71)\end{array}$ & $\begin{array}{c}6.7 \\
(7.17)\end{array}$ & $\begin{array}{c}0.7 \\
(1.49)\end{array}$ & $\begin{array}{c}16.1 \\
(25.56)\end{array}$ & $\begin{array}{c}37.8 \\
(26.08)\end{array}$ & $\begin{array}{c}16 \\
(27.26)\end{array}$ & $\begin{array}{c}2 \\
(2.98)\end{array}$ & $\begin{array}{c}0 \\
(0.00)\end{array}$ & $\begin{array}{c}0.20 \\
(0.42)\end{array}$ & $\begin{array}{c}24.80 \\
(41.13)\end{array}$ \\
\hline Macrocystis pyrifera $>1 \mathrm{~m}$ & $\begin{array}{c}8.2 \\
(3.58)\end{array}$ & $\begin{array}{c}7.9 \\
(7.49)\end{array}$ & $\begin{array}{c}4.5 \\
(3.92)\end{array}$ & $\begin{array}{c}2.8 \\
(4.24)\end{array}$ & $\begin{array}{c}16.8 \\
(16.34)\end{array}$ & $\begin{array}{c}10.8 \\
(4.71)\end{array}$ & $\begin{array}{c}6.3 \\
(2.91)\end{array}$ & $\begin{array}{c}5.8 \\
(3.33)\end{array}$ & $\begin{array}{c}2.10 \\
(1.52)\end{array}$ & $\begin{array}{c}1.20 \\
(1.55)\end{array}$ \\
\hline Megastraea undosa & $\begin{array}{c}0.4 \\
(0.84)\end{array}$ & $\begin{array}{c}0.3 \\
(0.48)\end{array}$ & $\begin{array}{c}0.3 \\
(0.67)\end{array}$ & $\begin{array}{c}0.5 \\
(0.71)\end{array}$ & $\begin{array}{c}0.4 \\
(0.70)\end{array}$ & $\begin{array}{c}0.4 \\
(0.70)\end{array}$ & $\begin{array}{c}0.7 \\
(0.95)\end{array}$ & $\begin{array}{c}1.6 \\
(1.26)\end{array}$ & $\begin{array}{c}2.90 \\
(2.23)\end{array}$ & $\begin{array}{c}8.00 \\
(5.54)\end{array}$ \\
\hline Megathura crenulata & $\begin{array}{c}1.1 \\
(1.29)\end{array}$ & $\begin{array}{c}1.1 \\
(1.60)\end{array}$ & $\begin{array}{c}0.4 \\
(0.70)\end{array}$ & $\begin{array}{c}0.3 \\
(0.48)\end{array}$ & $\begin{array}{c}0.6 \\
(0.70)\end{array}$ & $\begin{array}{c}0.5 \\
(0.71)\end{array}$ & $\begin{array}{c}1.1 \\
(1.10)\end{array}$ & $\begin{array}{c}0.9 \\
(1.29)\end{array}$ & $\begin{array}{c}0.80 \\
(1.03)\end{array}$ & $\begin{array}{c}0.50 \\
(0.53)\end{array}$ \\
\hline Apostichopus parvimensis & $\begin{array}{c}0.3 \\
(0.67)\end{array}$ & $\begin{array}{c}1 \\
(1.49)\end{array}$ & $\begin{array}{c}0.1 \\
(0.32)\end{array}$ & $\begin{array}{c}1.8 \\
(1.40)\end{array}$ & $\begin{array}{c}0.9 \\
(1.10)\end{array}$ & $\begin{array}{c}3.9 \\
(3.48)\end{array}$ & $\begin{array}{c}0.3 \\
(0.67)\end{array}$ & $\begin{array}{c}2.9 \\
(3.31)\end{array}$ & $\begin{array}{c}0.30 \\
(0.67)\end{array}$ & $\begin{array}{c}3.50 \\
(5.68)\end{array}$ \\
\hline Pycnopodia helianthoides & $\begin{array}{c}0 \\
(0.00)\end{array}$ & $\begin{array}{c}0 \\
(0.00)\end{array}$ & $\begin{array}{c}0 \\
(0.00)\end{array}$ & $\begin{array}{c}0 \\
(0.00)\end{array}$ & $\begin{array}{c}0 \\
(0.00)\end{array}$ & $\begin{array}{c}0 \\
(0.00)\end{array}$ & $\begin{array}{c}0 \\
(0.00)\end{array}$ & $\begin{array}{c}0 \\
(0.00)\end{array}$ & $\begin{array}{c}0 \\
(0.00)\end{array}$ & $\begin{array}{c}0 \\
(0.00)\end{array}$ \\
\hline Sargassum horneri & $\begin{array}{c}0 \\
(0.00)\end{array}$ & $\begin{array}{c}0 \\
(0.00)\end{array}$ & $\begin{array}{c}0 \\
(0.00)\end{array}$ & $\begin{array}{c}0 \\
(0.00)\end{array}$ & $\begin{array}{c}0 \\
(0.00)\end{array}$ & $\begin{array}{c}0 \\
(0.00)\end{array}$ & $\begin{array}{c}0 \\
(0.00)\end{array}$ & $\begin{array}{c}0 \\
(0.00)\end{array}$ & $\begin{array}{c}0 \\
(0.00)\end{array}$ & $\begin{array}{c}0 \\
(0.00)\end{array}$ \\
\hline Strongylocentrotus franciscanus & $\begin{array}{c}39.8 \\
(27.74)\end{array}$ & $\begin{array}{c}52.9 \\
(36.80)\end{array}$ & $\begin{array}{c}47 \\
(21.59)\end{array}$ & $\begin{array}{c}42.3 \\
(24.01)\end{array}$ & $\begin{array}{c}38 \\
(20.80)\end{array}$ & $\begin{array}{c}29.8 \\
(14.95)\end{array}$ & $\begin{array}{c}59.8 \\
(31.08)\end{array}$ & $\begin{array}{c}62.9 \\
(31.09)\end{array}$ & $\begin{array}{c}53.60 \\
(28.91)\end{array}$ & $\begin{array}{c}56.90 \\
(26.58)\end{array}$ \\
\hline Strongylocentrotus purpuratus & $\begin{array}{c}161 \\
(79.38)\end{array}$ & $\begin{array}{c}238.8 \\
(126.53)\end{array}$ & $\begin{array}{c}228 \\
(118.44)\end{array}$ & $\begin{array}{c}190.6 \\
(99.64)\end{array}$ & $\begin{array}{c}209 \\
(90.74)\end{array}$ & $\begin{array}{c}198.7 \\
(99.72)\end{array}$ & $\begin{array}{c}341.4 \\
(149.43)\end{array}$ & $\begin{array}{c}401.5 \\
(204.87)\end{array}$ & $\begin{array}{c}326.20 \\
(136.24)\end{array}$ & $\begin{array}{c}391.30 \\
(184.02)\end{array}$ \\
\hline Tethya aurantia & $\begin{array}{c}12.3 \\
(9.32)\end{array}$ & $\begin{array}{c}7.4 \\
(5.99)\end{array}$ & $\begin{array}{c}5.4 \\
(6.59)\end{array}$ & $\begin{array}{c}6.1 \\
(5.99)\end{array}$ & $\begin{array}{c}6.6 \\
(4.14)\end{array}$ & $\begin{array}{c}7 \\
(5.23)\end{array}$ & $\begin{array}{c}5.2 \\
(4.39)\end{array}$ & $\begin{array}{c}7.4 \\
(5.38)\end{array}$ & $\begin{array}{c}5.70 \\
(2.98)\end{array}$ & $\begin{array}{c}7.40 \\
(5.72)\end{array}$ \\
\hline Tealia lofotensis & $\begin{array}{c}27.2 \\
(15.02)\end{array}$ & $\begin{array}{c}41.5 \\
(20.45)\end{array}$ & $\begin{array}{c}28.5 \\
(16.26)\end{array}$ & $\begin{array}{c}28.1 \\
(18.04)\end{array}$ & $\begin{array}{c}35.9 \\
(19.49)\end{array}$ & $\begin{array}{c}34.6 \\
(18.37)\end{array}$ & $\begin{array}{c}35 \\
(25.62)\end{array}$ & $\begin{array}{c}40.8 \\
(25.93)\end{array}$ & $\begin{array}{c}37.50 \\
(21.45)\end{array}$ & $\begin{array}{c}38.60 \\
(22.23)\end{array}$ \\
\hline Young Laminariales & $\begin{array}{c}3.9 \\
(3.45)\end{array}$ & $\begin{array}{c}6.9 \\
(6.51)\end{array}$ & $\begin{array}{c}3.9 \\
(6.38)\end{array}$ & $\begin{array}{c}9.9 \\
(18.88)\end{array}$ & $\begin{array}{c}5.6 \\
(11.95)\end{array}$ & $\begin{array}{c}2.3 \\
(3.80)\end{array}$ & $\begin{array}{c}1 \\
(2.16)\end{array}$ & $\begin{array}{c}5.3 \\
(8.41)\end{array}$ & $\begin{array}{c}1.20 \\
(2.57)\end{array}$ & $\begin{array}{c}7.10 \\
(12.27)\end{array}$ \\
\hline
\end{tabular}




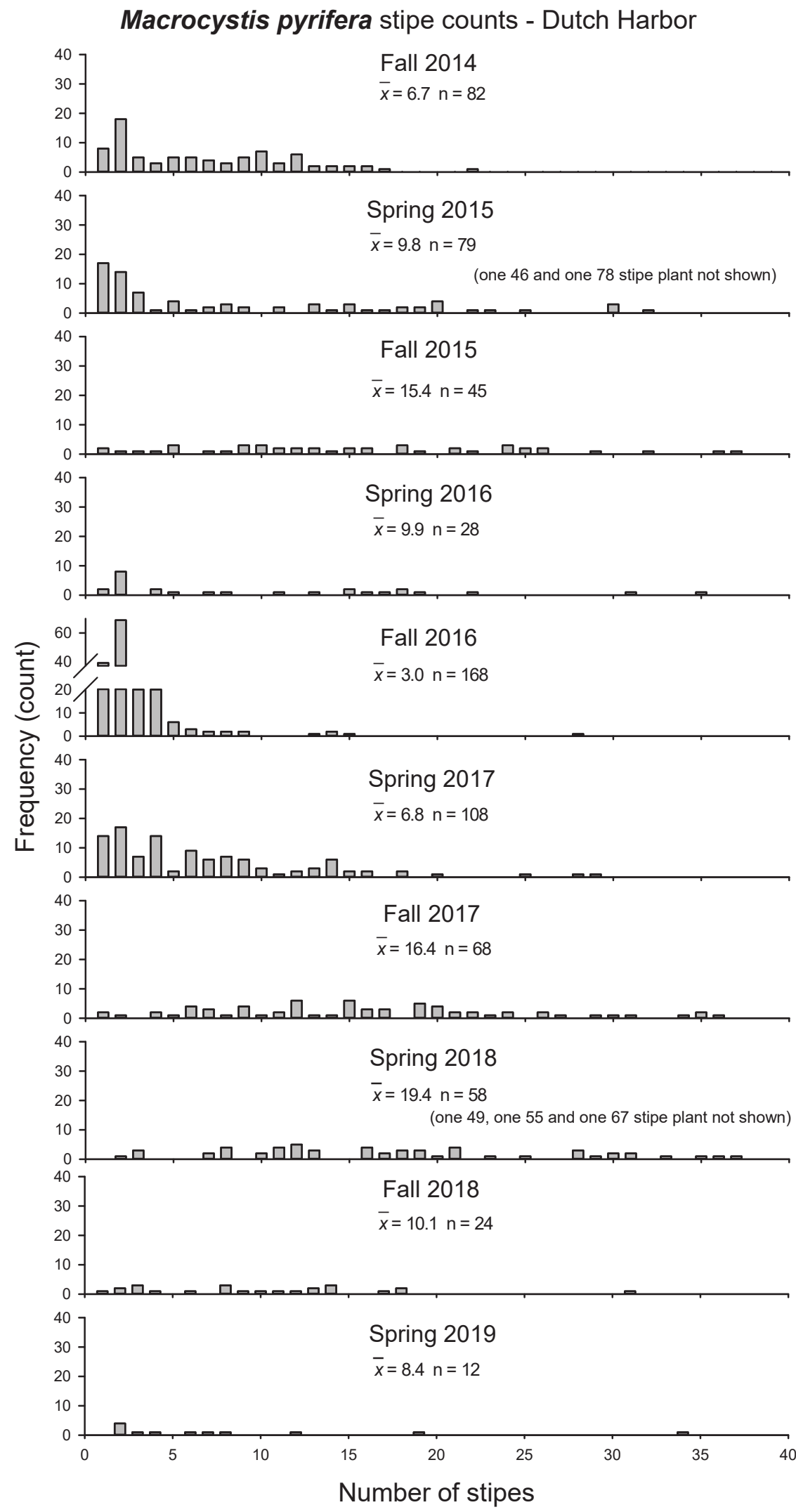

Figure 28. Dutch Harbor Macrocystis pyrifera greater than 1-meter (m) tall stipe counts by season in fall 2014-spring 2019. [ $\bar{x}$ is mean count, $\mathrm{n}$ is number of individuals] 
Macrocystis pyrifera holdfast diameters - Dutch Harbor
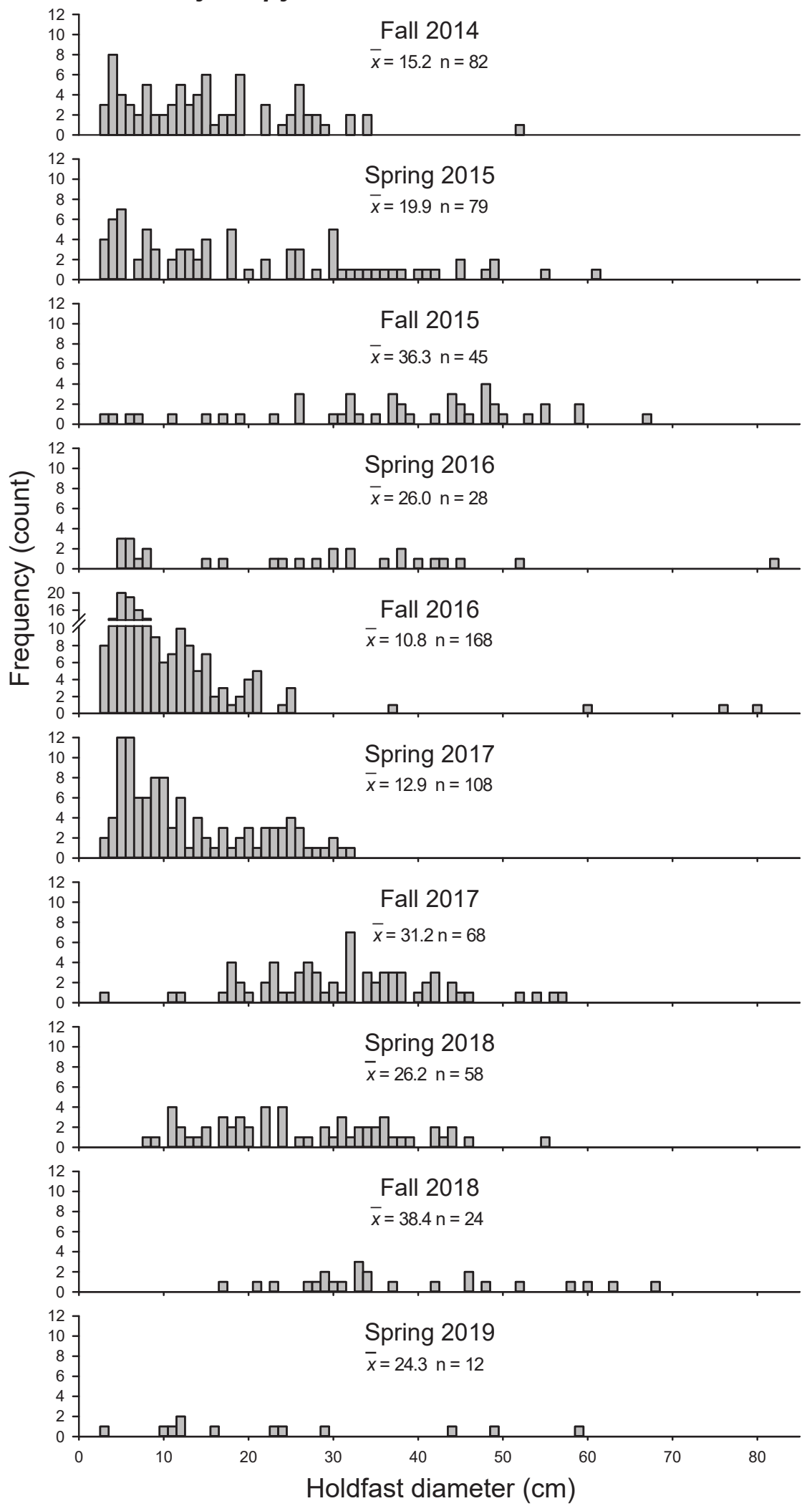

Figure 29. Dutch Harbor Macrocystis pyrifera greater than 1-meter (m) tall holdfast diameters by season in fall 2014-spring 2019. [ $\bar{x}$ is mean diameter, $\mathrm{n}$ is number of individuals] 
Table 22. Sizes of invertebrates measured on swaths at Dutch Harbor in fall 2014 through spring 2019.

[Strongylocentrotus spp. excluded. See figures 30 and 31 for purple and red urchin size data. Abbreviations: N, sample size; Min, minimum; —, no data; Max, maximum]

\begin{tabular}{|c|c|c|c|c|c|c|c|}
\hline \multirow[b]{2}{*}{ Size } & \multicolumn{7}{|c|}{ Species name } \\
\hline & $\begin{array}{c}\text { Crassadoma } \\
\text { gigantea }\end{array}$ & $\begin{array}{c}\text { Dermasterias } \\
\text { imbricata }\end{array}$ & $\begin{array}{r}\text { Kelletia } \\
\text { kelletii }\end{array}$ & $\begin{array}{c}\text { Megastraea } \\
\text { undosa }\end{array}$ & $\begin{array}{c}\text { Megathura } \\
\text { crenulata }\end{array}$ & $\begin{array}{l}\text { Patiria } \\
\text { miniata }\end{array}$ & $\begin{array}{l}\text { Pisaster } \\
\text { giganteus }\end{array}$ \\
\hline \multicolumn{8}{|c|}{ Year 1: Fall 2014} \\
\hline $\mathrm{N}$ & 16 & 0 & 5 & 4 & 11 & 20 & 0 \\
\hline Min & 19 & - & 65 & 25 & 66 & 27 & - \\
\hline Max & 113 & - & 75 & 90 & 117 & 94 & - \\
\hline Mean & 59.2 & - & 71.4 & 63.8 & 100.0 & 60.3 & - \\
\hline \multicolumn{8}{|c|}{ Year 1: Spring 2015} \\
\hline $\mathrm{N}$ & 17 & 0 & 9 & 3 & 11 & 28 & 0 \\
\hline Min & 25 & - & 40 & 39 & 90 & 36 & - \\
\hline Max & 115 & - & 98 & 75 & 162 & 90 & - \\
\hline Mean & 60.9 & - & 76.3 & 52.0 & 124.8 & 62.0 & - \\
\hline \multicolumn{8}{|c|}{ Year 2: Fall 2015} \\
\hline $\mathrm{N}$ & 108 & 0 & 7 & 3 & 4 & 4 & 0 \\
\hline Min & 20 & - & 31 & 28 & 54 & 40 & - \\
\hline Max & 100 & - & 108 & 99 & 148 & 70 & - \\
\hline Mean & 58.8 & - & 55.3 & 54.0 & 102.2 & 56.8 & - \\
\hline \multicolumn{8}{|c|}{ Year 2: Spring 2016} \\
\hline $\mathrm{N}$ & 30 & 1 & 7 & 5 & 3 & 8 & 0 \\
\hline Min & 15 & 80 & 30 & 45 & 109 & 21 & - \\
\hline Max & 95 & 80 & 90 & 120 & 115 & 85 & - \\
\hline Mean & 67.4 & 80.5 & 56.7 & 77.0 & 111.3 & 55.5 & - \\
\hline \multicolumn{8}{|c|}{ Year 3: Fall 2016} \\
\hline $\mathrm{N}$ & 68 & 0 & 5 & 4 & 6 & 16 & 0 \\
\hline Min & 19 & - & 27 & 17 & 102 & 24 & - \\
\hline $\operatorname{Max}$ & 112 & - & 80 & 80 & 125 & 80 & - \\
\hline Mean & 61.0 & - & 49.8 & 49.0 & 116.3 & 56.4 & - \\
\hline \multicolumn{8}{|c|}{ Year 3: Spring 2017} \\
\hline $\mathrm{N}$ & 60 & 0 & 0 & 4 & 5 & 8 & 0 \\
\hline Min & 15 & - & - & 40 & 75 & 23 & - \\
\hline Max & 110 & - & - & 50 & 120 & 73 & - \\
\hline Mean & 63.0 & - & - & 45.0 & 101.4 & 56.4 & - \\
\hline \multicolumn{8}{|c|}{ Year 4: Fall 2017} \\
\hline $\mathrm{N}$ & 158 & 0 & 1 & 8 & 11 & 20 & 0 \\
\hline Min & 26 & - & 47 & 37 & 28 & 20 & - \\
\hline Max & 113 & - & 47 & 81 & 125 & 91 & - \\
\hline Mean & 65.0 & - & 47.0 & 52.0 & 95.8 & 61.3 & - \\
\hline \multicolumn{8}{|c|}{ Year 4: Spring 2018} \\
\hline $\mathrm{N}$ & 130 & 0 & 23 & 16 & 9 & 23 & 3 \\
\hline Min & 21 & - & 24 & 24 & 70 & 7 & 55 \\
\hline Max & 120 & - & 113 & 82 & 115 & 92 & 110 \\
\hline Mean & 59.9 & - & 51.4 & 50.3 & 91.9 & 60.1 & 77.3 \\
\hline
\end{tabular}


Table 22. Sizes of invertebrates measured on swaths at Dutch Harbor in fall 2014 through spring 2019.-Continued

[Strongylocentrotus spp. excluded. See figures 30 and 31 for purple and red urchin size data. Abbreviations: N, sample size; Min, minimum; _, no data; Max, maximum]

\begin{tabular}{|c|c|c|c|c|c|c|c|}
\hline \multirow[b]{2}{*}{ Size } & \multicolumn{7}{|c|}{ Species name } \\
\hline & $\begin{array}{l}\text { Crassadoma } \\
\text { gigantea }\end{array}$ & $\begin{array}{c}\text { Dermasterias } \\
\text { imbricata }\end{array}$ & $\begin{array}{r}\text { Kelletia } \\
\text { kelletii }\end{array}$ & $\begin{array}{c}\text { Megastraea } \\
\text { undosa }\end{array}$ & $\begin{array}{c}\text { Megathura } \\
\text { crenulata }\end{array}$ & $\begin{array}{l}\text { Patiria } \\
\text { miniata }\end{array}$ & $\begin{array}{c}\text { Pisaster } \\
\text { giganteus }\end{array}$ \\
\hline \multicolumn{8}{|c|}{ Year 5: Fall 2018} \\
\hline $\mathrm{N}$ & 188 & 0 & 5 & 46 & 9 & 18 & 0 \\
\hline Min & 24 & - & 38 & 35 & 102 & 40 & - \\
\hline $\operatorname{Max}$ & 150 & - & 47 & 80 & 130 & 87 & - \\
\hline Mean & 73.4 & - & 41.8 & 58.0 & 116.6 & 64.2 & - \\
\hline \multicolumn{8}{|c|}{ Year 5: Spring 2019} \\
\hline $\mathrm{N}$ & 166 & 0 & 26 & 84 & 5 & 27 & 1 \\
\hline Min & 24 & - & 29 & 28 & 67 & 26 & 45 \\
\hline $\operatorname{Max}$ & 125 & - & 84 & 92 & 114 & 101 & 45 \\
\hline Mean & 68.2 & - & 55.1 & 59.0 & 96.6 & 59.4 & 45.0 \\
\hline
\end{tabular}


Strongylocentrotus purpuratus - Dutch Harbor
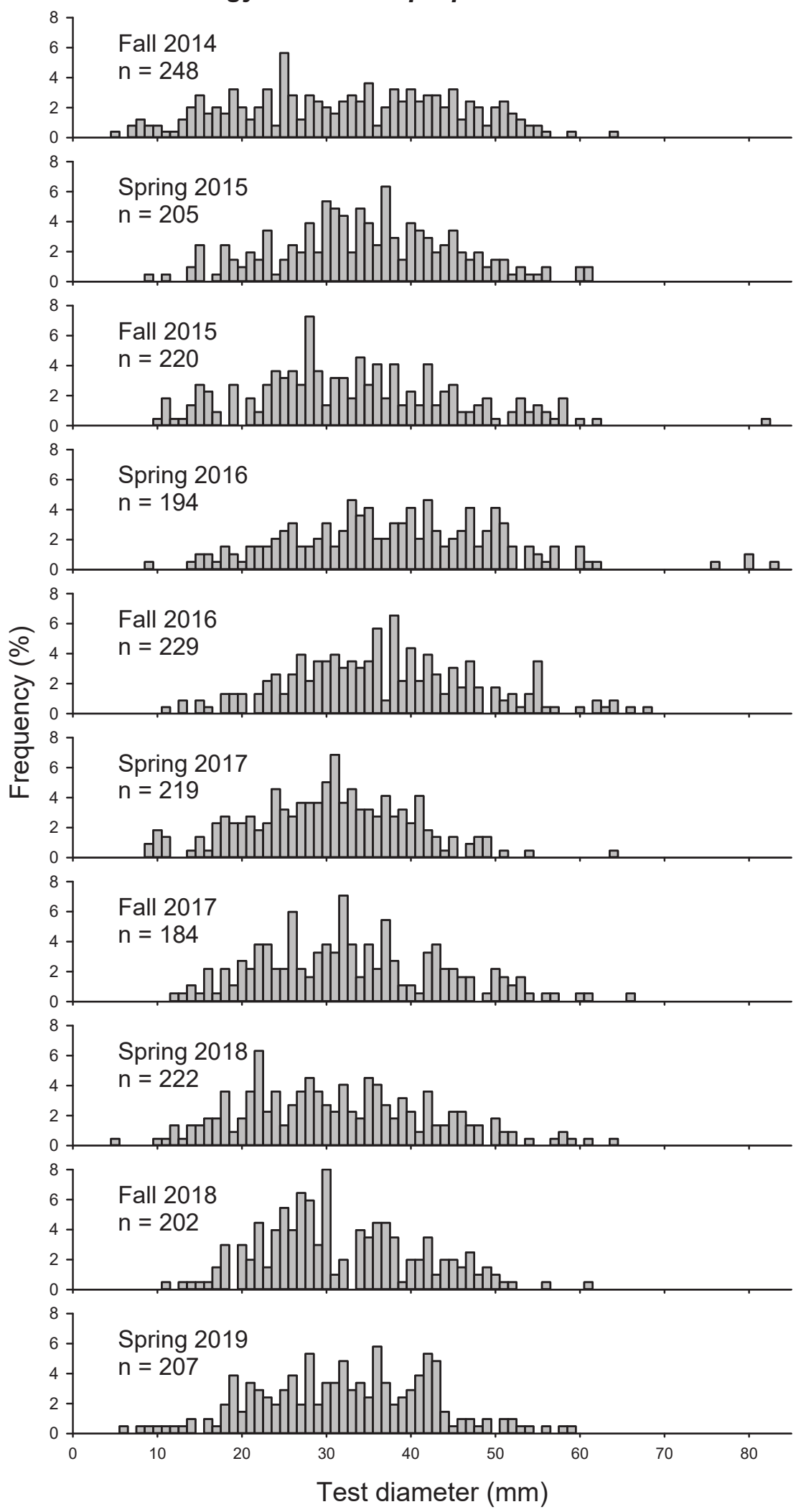

Figure 30. Dutch Harbor size structure of purple urchins (Strongylocentrotus purpuratus) in fall 2014-spring 2019. [ $\mathrm{n}$ = number of individuals] 
Strongylocentrotus franciscanus - Dutch Harbor
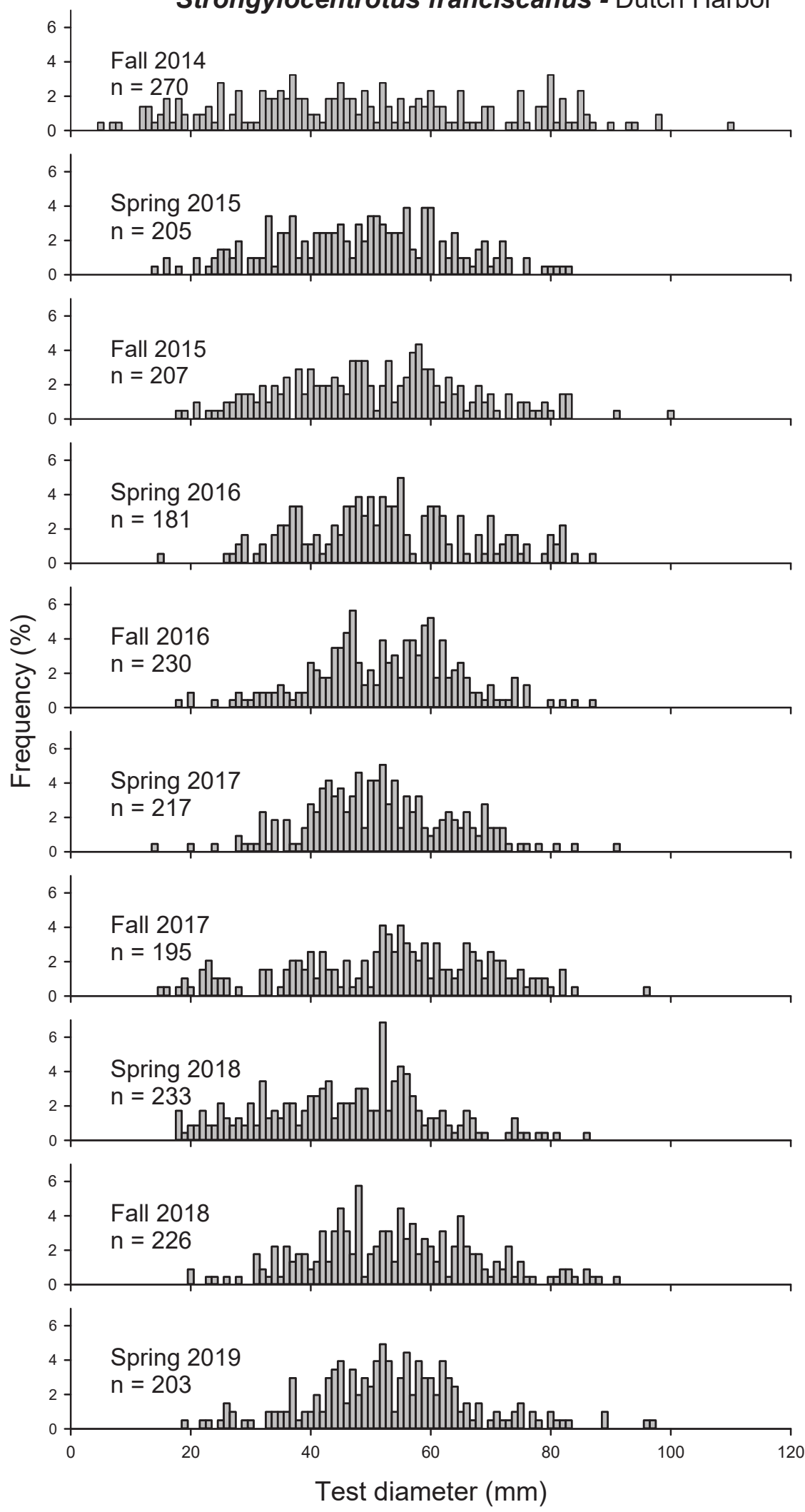

Figure 31. Dutch Harbor size structure of red urchins (Strongylocentrotus franciscanus) in fall 2014-spring 2019. [ $n=$ number of individuals] 
Table 23. Mean (and standard deviation) numbers of rare species counted on twenty 1-square meter quadrats from Dutch Harbor in fall 2014 through spring 2019.

\begin{tabular}{|c|c|c|c|c|c|c|c|c|c|c|}
\hline Species name & $\begin{array}{l}\text { Fall } \\
2014\end{array}$ & $\begin{array}{c}\text { Spring } \\
2015\end{array}$ & $\begin{array}{l}\text { Fall } \\
2015\end{array}$ & $\begin{array}{c}\text { Spring } \\
2016\end{array}$ & $\begin{array}{c}\text { Fall } \\
2016\end{array}$ & $\begin{array}{c}\text { Spring } \\
2017\end{array}$ & $\begin{array}{l}\text { Fall } \\
2017\end{array}$ & $\begin{array}{c}\text { Spring } \\
2018\end{array}$ & $\begin{array}{l}\text { Fall } \\
2018\end{array}$ & $\begin{array}{c}\text { Spring } \\
2019\end{array}$ \\
\hline rosa & $\begin{array}{c}0.1 \\
(0.22)\end{array}$ & $\begin{array}{c}0.0 \\
(0.00)\end{array}$ & $\begin{array}{c}0.0 \\
(0.00)\end{array}$ & $\begin{array}{c}0.0 \\
(0.00)\end{array}$ & $\begin{array}{c}0.0 \\
(0.00)\end{array}$ & $\begin{array}{c}0.1 \\
(0.22)\end{array}$ & $\begin{array}{c}0.0 \\
(0.00)\end{array}$ & $\begin{array}{c}0.0 \\
(0.00)\end{array}$ & $\begin{array}{c}0.0 \\
(0.00)\end{array}$ & $\begin{array}{c}0.0 \\
(0.00)\end{array}$ \\
\hline Cypr & $\begin{array}{c}0.0 \\
(0.00)\end{array}$ & $\begin{array}{c}0.1 \\
(0.45)\end{array}$ & $\begin{array}{c}0.1 \\
(0.22)\end{array}$ & $\begin{array}{c}0.1 \\
(0.31)\end{array}$ & $\begin{array}{c}0.0 \\
(0.00)\end{array}$ & $\begin{array}{c}0.0 \\
(0.00)\end{array}$ & $\begin{array}{c}0.0 \\
(0.00)\end{array}$ & $\begin{array}{c}0.1 \\
(0.22)\end{array}$ & $\begin{array}{c}0.0 \\
(0.00)\end{array}$ & $\begin{array}{c}0.0 \\
(0.00)\end{array}$ \\
\hline Kelle & $\begin{array}{c}0.0 \\
(0.00)\end{array}$ & $\begin{array}{c}0.1 \\
(0.45)\end{array}$ & $\begin{array}{c}0.0 \\
(0.00)\end{array}$ & $\begin{array}{c}0.0 \\
(0.00)\end{array}$ & $\begin{array}{c}0.0 \\
(0.00)\end{array}$ & $\begin{array}{c}0.0 \\
(0.00)\end{array}$ & $\begin{array}{c}0.0 \\
(0.00)\end{array}$ & $\begin{array}{c}0.0 \\
(0.00)\end{array}$ & $\begin{array}{c}0.0 \\
(0.00)\end{array}$ & $\begin{array}{c}0.1 \\
(0.22)\end{array}$ \\
\hline Nort & $\begin{array}{c}0.1 \\
(0.45)\end{array}$ & $\begin{array}{c}0.0 \\
(0.00)\end{array}$ & $\begin{array}{c}0.0 \\
(0.00)\end{array}$ & $\begin{array}{c}0.0 \\
(0.00)\end{array}$ & $\begin{array}{c}0.1 \\
(0.22)\end{array}$ & $\begin{array}{c}0.1 \\
(0.22)\end{array}$ & $\begin{array}{c}0.0 \\
(0.00)\end{array}$ & $\begin{array}{c}0.0 \\
(0.00)\end{array}$ & $\begin{array}{c}0.0 \\
(0.00)\end{array}$ & $\begin{array}{c}0.0 \\
(0.00)\end{array}$ \\
\hline Sar & $\begin{array}{c}0.0 \\
(0.00)\end{array}$ & $\begin{array}{c}0.0 \\
(0.00)\end{array}$ & $\begin{array}{c}0.0 \\
(0.00)\end{array}$ & $\begin{array}{c}0.0 \\
(0.00)\end{array}$ & $\begin{array}{c}0.0 \\
(0.00)\end{array}$ & $\begin{array}{c}0.0 \\
(0.00)\end{array}$ & $\begin{array}{c}0.0 \\
(0.00)\end{array}$ & $\begin{array}{c}0.0 \\
(0.00)\end{array}$ & $\begin{array}{c}0.0 \\
(0.00)\end{array}$ & $\begin{array}{c}0.0 \\
(0.00)\end{array}$ \\
\hline Sty & $\begin{array}{c}0.1 \\
(0.31)\end{array}$ & $\begin{array}{c}0.0 \\
(0.00)\end{array}$ & $\begin{array}{c}0.0 \\
(0.00)\end{array}$ & $\begin{array}{c}0.1 \\
(0.45)\end{array}$ & $\begin{array}{c}0.2 \\
(0.67)\end{array}$ & $\begin{array}{c}0.2 \\
(0.49)\end{array}$ & $\begin{array}{c}0.2 \\
(0.49)\end{array}$ & $\begin{array}{c}0.1 \\
(0.31)\end{array}$ & $\begin{array}{c}0.1 \\
(0.31)\end{array}$ & $\begin{array}{c}0.1 \\
(0.31)\end{array}$ \\
\hline Tegula regina & $\begin{array}{c}0.0 \\
(0.00)\end{array}$ & $\begin{array}{c}0.0 \\
(0.00)\end{array}$ & $\begin{array}{c}0.0 \\
(0.00)\end{array}$ & $\begin{array}{c}0.0 \\
(0.00)\end{array}$ & $\begin{array}{c}0.0 \\
(0.00)\end{array}$ & $\begin{array}{c}0.0 \\
(0.00)\end{array}$ & $\begin{array}{c}0.0 \\
(0.00)\end{array}$ & $\begin{array}{c}0.0 \\
(0.00)\end{array}$ & $\begin{array}{c}0.1 \\
(0.22)\end{array}$ & $\begin{array}{c}0.0 \\
(0.00)\end{array}$ \\
\hline Tethya & $\begin{array}{c}0.3 \\
(0.57)\end{array}$ & $\begin{array}{c}0.4 \\
(0.68)\end{array}$ & $\begin{array}{c}0.1 \\
(0.31)\end{array}$ & $\begin{array}{c}0.2 \\
(0.41)\end{array}$ & $\begin{array}{c}0.1 \\
(0.22)\end{array}$ & $\begin{array}{c}0.2 \\
(0.37)\end{array}$ & $\begin{array}{c}0.1 \\
(0.31)\end{array}$ & $\begin{array}{c}0.2 \\
(0.41)\end{array}$ & $\begin{array}{c}0.3 \\
(0.44)\end{array}$ & $\begin{array}{c}0.2 \\
(0.37)\end{array}$ \\
\hline Tealia lofoter & $\begin{array}{c}0.4 \\
(0.75)\end{array}$ & $\begin{array}{c}0.6 \\
(0.89)\end{array}$ & $\begin{array}{c}0.7 \\
(1.03)\end{array}$ & $\begin{array}{c}0.6 \\
(0.94)\end{array}$ & $\begin{array}{c}0.6 \\
(1.05)\end{array}$ & $\begin{array}{c}0.7 \\
(0.93)\end{array}$ & $\begin{array}{c}0.8 \\
(0.85)\end{array}$ & $\begin{array}{c}0.5 \\
(0.76)\end{array}$ & $\begin{array}{c}0.3 \\
(0.55)\end{array}$ & $\begin{array}{c}0.6 \\
(0.89)\end{array}$ \\
\hline
\end{tabular}

Table 24. Dutch Harbor point contact “species" ranked by the sum of points for fall 2014 through spring 2019.

$[>$, greater than; $\mathrm{m}$, meter; $<$, less than $]$

\begin{tabular}{|c|c|c|c|c|c|c|c|c|c|c|}
\hline Species name & $\begin{array}{l}\text { Fall } \\
2014 \\
\end{array}$ & $\begin{array}{c}\text { Spring } \\
2015\end{array}$ & $\begin{array}{l}\text { Fall } \\
2015 \\
\end{array}$ & $\begin{array}{c}\text { Spring } \\
2016\end{array}$ & $\begin{array}{l}\text { Fall } \\
2016\end{array}$ & $\begin{array}{c}\text { Spring } \\
2017\end{array}$ & $\begin{array}{l}\text { Fall } \\
2017\end{array}$ & $\begin{array}{c}\text { Spring } \\
2018\end{array}$ & $\begin{array}{l}\text { Fall } \\
2018 \\
\end{array}$ & $\begin{array}{c}\text { Spring } \\
2019\end{array}$ \\
\hline Encrusting coralline algae & 182 & 129 & 187 & 128 & 151 & 122 & 167 & 139 & 137 & 167 \\
\hline Sand & 79 & 112 & 67 & 50 & 67 & 39 & 50 & 62 & 75 & 77 \\
\hline Laminaria spp. & 45 & 57 & 46 & 47 & 43 & 40 & 58 & 50 & 43 & 38 \\
\hline Cystoseira osmundacea & 38 & 27 & 38 & 27 & 33 & 43 & 56 & 45 & 32 & 55 \\
\hline Diopatra ornata & 33 & 43 & 19 & 26 & 42 & 22 & 18 & 41 & 40 & 44 \\
\hline Pink encrusting bryozoan & 5 & 16 & 23 & 40 & 33 & 33 & 58 & 66 & 35 & 17 \\
\hline Pachythyone rubra & 13 & 29 & 25 & 19 & 35 & 44 & 69 & 36 & 28 & 11 \\
\hline Cucumaria piperata & 24 & 39 & 23 & 17 & 19 & 30 & 31 & 22 & 33 & 31 \\
\hline Rhodymenia californica & 64 & 42 & 14 & 24 & 29 & 44 & 19 & 5 & 9 & 16 \\
\hline Calliarthron spp. & 27 & 34 & 18 & 19 & 18 & 16 & 15 & 9 & 9 & 12 \\
\hline Cryptopleura spp. & 13 & 16 & 2 & 27 & 42 & 34 & 9 & 1 & 18 & 14 \\
\hline Corallina officinalis & 27 & 20 & 12 & 2 & 16 & 19 & 15 & 24 & 10 & 16 \\
\hline Bare substratum & 10 & 8 & 23 & 13 & 9 & 19 & 7 & 12 & 10 & 29 \\
\hline Eisenia arborea & 16 & 15 & 9 & 14 & 23 & 19 & 17 & 4 & 10 & 10 \\
\hline Encrusting red algae & 8 & 11 & 14 & 9 & 8 & 11 & 13 & 9 & 13 & 11 \\
\hline Dictyota binghamiae & 5 & 24 & 0 & 14 & 21 & 14 & 0 & 1 & 8 & 19 \\
\hline Crisia spp. & 6 & 11 & 5 & 16 & 3 & 13 & 15 & 18 & 5 & 11 \\
\hline Aglaophenia spp. & 6 & 1 & 6 & 3 & 14 & 16 & 16 & 10 & 24 & 5 \\
\hline Kelp holdfast & 5 & 2 & 18 & 21 & 13 & 10 & 8 & 6 & 8 & 3 \\
\hline Corynactis californica & 12 & 9 & 7 & 6 & 13 & 9 & 7 & 4 & 1 & 4 \\
\hline
\end{tabular}


Table 24. Dutch Harbor point contact "species" ranked by the sum of points for fall 2014 through spring 2019._-Continued [ $>$, greater than; $\mathrm{m}$, meter; $<$, less than]

\begin{tabular}{|c|c|c|c|c|c|c|c|c|c|c|}
\hline Species name & Fall 2014 & $\begin{array}{c}\text { Spring } \\
2015\end{array}$ & Fall 2015 & $\begin{array}{c}\text { Spring } \\
2016\end{array}$ & Fall 2016 & $\begin{array}{c}\text { Spring } \\
2017\end{array}$ & Fall 2017 & $\begin{array}{c}\text { Spring } \\
2018\end{array}$ & Fall 2018 & $\begin{array}{c}\text { Spring } \\
2019\end{array}$ \\
\hline Astrangia lajollaensis & 4 & 8 & 3 & 5 & 7 & 6 & 6 & 9 & 10 & 8 \\
\hline Macrocystis pyrifera $>1 \mathrm{~m}$ & 8 & 0 & 9 & 16 & 5 & 7 & 8 & 5 & 6 & 2 \\
\hline Plocamium pacificum & 2 & 13 & 3 & 10 & 4 & 8 & 3 & 10 & 8 & 4 \\
\hline Cellaria spp. & 0 & 5 & 10 & 5 & 7 & 0 & 13 & 12 & 7 & 3 \\
\hline Balanophyllia elegans & 4 & 6 & 7 & 12 & 6 & 3 & 4 & 7 & 0 & 3 \\
\hline Barnacle & 12 & 6 & 29 & 0 & 0 & 0 & 0 & 0 & 0 & 0 \\
\hline Pterygophora californica & 8 & 15 & 8 & 3 & 4 & 4 & 2 & 0 & 2 & 0 \\
\hline Acarnus erithacus & 9 & 3 & 3 & 4 & 2 & 3 & 3 & 4 & 6 & 2 \\
\hline Macrocystis pyrifera $<1 \mathrm{~m}$ & 6 & 1 & 0 & 7 & 14 & 5 & 2 & 0 & 0 & 4 \\
\hline Nienburgia andersoniana & 1 & 4 & 1 & 2 & 4 & 9 & 1 & 4 & 0 & 3 \\
\hline Diatom film & 0 & 0 & 0 & 0 & 0 & 0 & 0 & 0 & 0 & 28 \\
\hline Hippodiplosia [Primavelans] insculpta & 1 & 1 & 1 & 5 & 0 & 4 & 9 & 3 & 4 & 0 \\
\hline Bossiella spp. & 3 & 8 & 3 & 1 & 3 & 0 & 3 & 0 & 1 & 3 \\
\hline Serpulorbis squamiger & 2 & 2 & 2 & 1 & 0 & 4 & 2 & 5 & 4 & 2 \\
\hline Eupentacta quinquesemita & 0 & 5 & 0 & 0 & 5 & 2 & 2 & 0 & 3 & 6 \\
\hline Lagenocella spp. & 1 & 1 & 2 & 6 & 4 & 0 & 3 & 2 & 3 & 0 \\
\hline Orange encrusting sponge & 0 & 4 & 1 & 2 & 6 & 1 & 4 & 3 & 1 & 0 \\
\hline Abietinaria spp. & 0 & 1 & 2 & 0 & 3 & 5 & 3 & 2 & 3 & 2 \\
\hline Acanthacora cyanocrypta & 1 & 2 & 0 & 0 & 0 & 1 & 2 & 6 & 6 & 0 \\
\hline Anthopleura sola & 2 & 4 & 0 & 3 & 4 & 2 & 0 & 1 & 0 & 2 \\
\hline Bugula spp. & 2 & 3 & 3 & 4 & 1 & 0 & 2 & 0 & 1 & 1 \\
\hline Filamentous red algae & 6 & 1 & 1 & 1 & 1 & 4 & 0 & 0 & 0 & 2 \\
\hline Phragmatopoma californica & 0 & 1 & 1 & 0 & 3 & 0 & 4 & 1 & 5 & 1 \\
\hline Urticina /Tealia spp. & 3 & 1 & 0 & 7 & 2 & 2 & 0 & 0 & 1 & 0 \\
\hline Phidolopora pacifica & 0 & 3 & 1 & 3 & 2 & 1 & 2 & 1 & 1 & 0 \\
\hline Gigartina exasperata & 4 & 0 & 0 & 0 & 3 & 2 & 1 & 0 & 0 & 1 \\
\hline Botryocladia pseudodichotoma & 0 & 0 & 0 & 0 & 2 & 2 & 1 & 3 & 0 & 1 \\
\hline Unidentified sponge & 0 & 1 & 0 & 2 & 1 & 0 & 2 & 1 & 0 & 2 \\
\hline Kallymenia pacifica & 0 & 0 & 0 & 0 & 2 & 1 & 0 & 3 & 1 & 1 \\
\hline Plumularia spp. & 0 & 0 & 0 & 0 & 0 & 0 & 0 & 4 & 1 & 3 \\
\hline Stylantheca porphyra & 0 & 0 & 0 & 1 & 0 & 3 & 2 & 1 & 0 & 1 \\
\hline Archidistoma psammion & 0 & 0 & 0 & 0 & 0 & 0 & 4 & 0 & 3 & 0 \\
\hline Tethya aurantia & 1 & 1 & 0 & 0 & 0 & 0 & 1 & 1 & 3 & 0 \\
\hline Didemnum carnulentum & 0 & 0 & 0 & 0 & 0 & 3 & 2 & 1 & 0 & 0 \\
\hline Strongylocentrotus purpuratus & 1 & 1 & 2 & 0 & 0 & 0 & 0 & 0 & 2 & 0 \\
\hline Young Laminariales & 1 & 3 & 0 & 1 & 1 & 0 & 0 & 0 & 0 & 0 \\
\hline Bryopsis corticulans & 0 & 0 & 0 & 0 & 0 & 1 & 0 & 0 & 2 & 1 \\
\hline Epiactis prolifera & 0 & 0 & 1 & 0 & 0 & 3 & 0 & 0 & 0 & 0 \\
\hline Red algal turf & 0 & 0 & 0 & 0 & 0 & 0 & 0 & 0 & 4 & 0 \\
\hline Cystodytes lobatus & 0 & 0 & 0 & 0 & 0 & 0 & 0 & 0 & 0 & 3 \\
\hline Dictyopteris undulata & 0 & 0 & 0 & 1 & 0 & 1 & 0 & 0 & 0 & 1 \\
\hline Gelidium robustum & 0 & 0 & 0 & 0 & 2 & 0 & 0 & 1 & 0 & 0 \\
\hline
\end{tabular}


Table 24. Dutch Harbor point contact "species" ranked by the sum of points for fall 2014 through spring 2019._-Continued

[ $>$, greater than; $\mathrm{m}$, meter; $<$, less than]

\begin{tabular}{|c|c|c|c|c|c|c|c|c|c|c|}
\hline Species name & Fall 2014 & $\begin{array}{c}\text { Spring } \\
2015\end{array}$ & Fall 2015 & $\begin{array}{c}\text { Spring } \\
2016\end{array}$ & Fall 2016 & $\begin{array}{c}\text { Spring } \\
2017\end{array}$ & Fall 2017 & $\begin{array}{c}\text { Spring } \\
2018\end{array}$ & Fall 2018 & $\begin{array}{c}\text { Spring } \\
2019\end{array}$ \\
\hline Laurencia pacifica & 0 & 2 & 0 & 0 & 0 & 0 & 0 & 0 & 0 & 1 \\
\hline Pterosiphonia spp. & 0 & 0 & 0 & 0 & 0 & 2 & 0 & 0 & 1 & 0 \\
\hline Spheciospongia confoederata & 1 & 0 & 0 & 1 & 0 & 0 & 0 & 0 & 0 & 1 \\
\hline Synoicum spp. & 0 & 0 & 0 & 0 & 3 & 0 & 0 & 0 & 0 & 0 \\
\hline Anthopleura spp. & 0 & 0 & 1 & 0 & 0 & 1 & 0 & 0 & 0 & 0 \\
\hline Lissothuria nutriens & 0 & 0 & 0 & 0 & 0 & 0 & 0 & 0 & 1 & 1 \\
\hline Mucus tube polychaete & 0 & 0 & 0 & 0 & 0 & 0 & 0 & 0 & 2 & 0 \\
\hline Styela montereyensis & 0 & 0 & 0 & 0 & 0 & 0 & 1 & 0 & 0 & 1 \\
\hline Unidentified bryozoan & 0 & 0 & 0 & 0 & 0 & 0 & 0 & 0 & 0 & 2 \\
\hline Balanus spp. & 0 & 0 & 0 & 0 & 1 & 0 & 0 & 0 & 0 & 0 \\
\hline Boltenia villosa & 0 & 0 & 0 & 0 & 0 & 1 & 0 & 0 & 0 & 0 \\
\hline Callophyllis flabellulata & 0 & 0 & 0 & 0 & 0 & 1 & 0 & 0 & 0 & 0 \\
\hline Clavelina huntsmani & 0 & 0 & 0 & 0 & 0 & 1 & 0 & 0 & 0 & 0 \\
\hline Codium fragile & 1 & 0 & 0 & 0 & 0 & 0 & 0 & 0 & 0 & 0 \\
\hline Codium setchellii/hubbsii & 0 & 0 & 0 & 0 & 1 & 0 & 0 & 0 & 0 & 0 \\
\hline Colpomenia spp. & 0 & 0 & 0 & 0 & 0 & 0 & 0 & 0 & 0 & 1 \\
\hline Crassadoma gigantea & 0 & 0 & 0 & 0 & 0 & 0 & 0 & 1 & 0 & 0 \\
\hline Desmarestia ligulata & 0 & 0 & 0 & 0 & 1 & 0 & 0 & 0 & 0 & 0 \\
\hline Filamentous green algae & 0 & 0 & 0 & 0 & 1 & 0 & 0 & 0 & 0 & 0 \\
\hline Leucetta $[$ Leucandra] losangelensis & 0 & 1 & 0 & 0 & 0 & 0 & 0 & 0 & 0 & 0 \\
\hline Opuntiella californica & 0 & 0 & 0 & 0 & 0 & 0 & 0 & 0 & 0 & 1 \\
\hline Pholad clam & 0 & 0 & 0 & 0 & 0 & 1 & 0 & 0 & 0 & 0 \\
\hline Pista elongata & 0 & 0 & 0 & 0 & 0 & 0 & 0 & 0 & 1 & 0 \\
\hline Prionitis lanceolata & 0 & 0 & 1 & 0 & 0 & 0 & 0 & 0 & 0 & 0 \\
\hline Strongylocentrotus franciscanus & 0 & 1 & 0 & 0 & 0 & 0 & 0 & 0 & 0 & 0 \\
\hline Unidentified brown algae & 0 & 0 & 0 & 0 & 0 & 0 & 0 & 0 & 0 & 1 \\
\hline Tealia lofotensis & 0 & 0 & 0 & 0 & 0 & 0 & 0 & 1 & 0 & 0 \\
\hline
\end{tabular}


Table 25. Dutch Harbor fish counts_adult (juvenile)—in fall 2014 through spring 2019 (by species).

[f, female; m, male]

\begin{tabular}{|c|c|c|c|c|c|c|c|c|c|c|}
\hline Species name & $\begin{array}{l}\text { Fall } \\
2014\end{array}$ & $\begin{array}{c}\text { Spring } \\
2015\end{array}$ & $\begin{array}{l}\text { Fall } \\
2015\end{array}$ & $\begin{array}{c}\text { Spring } \\
2016\end{array}$ & $\begin{array}{l}\text { Fall } \\
2016\end{array}$ & $\begin{array}{c}\text { Spring } \\
2017\end{array}$ & $\begin{array}{l}\text { Fall } \\
2017\end{array}$ & $\begin{array}{c}\text { Spring } \\
2018\end{array}$ & $\begin{array}{l}\text { Fall } \\
2018\end{array}$ & $\begin{array}{c}\text { Spring } \\
2019\end{array}$ \\
\hline Artedius spp. & 0 & 0 & 0 & 0 & 0 & 0 & 0 & 0 & 2 & 0 \\
\hline Atherinops affinis & 0 & 0 & 0 & 0 & 185 & 0 & 145 & 0 & 8 & 110 \\
\hline Brachyistius frenatus & 52 & 5 & 18 & 2 & 31 & 0 & 3 & 10 & 5 & 4 \\
\hline Caulolatilus princeps & 0 & 0 & 0 & 1 & 0 & 0 & 4 & 0 & 0 & 4 \\
\hline Cephaloscyllium ventriosum & 0 & 0 & 0 & 4 & 0 & 0 & 0 & 0 & 0 & 0 \\
\hline Chromis punctipinnis & 4,044 & $1,435(405)$ & 1,581 & 1,461 & $1,711(70)$ & 1,110 & 976 & 1,193 & 1,427 & 2,647 \\
\hline Rhinogobiops nicholsii & 36 & 12 & 11 & 1 & 8 & 10 & 8 & 2 & 6 & 14 \\
\hline Embiotoca jacksoni & 40 & $22(2)$ & 62 & 25 & 43 & 27 & 67 & 64 & 45 & 27 \\
\hline Embiotoca lateralis & 43 & $21(3)$ & 27 & 15 & 19 & 12 & 24 & 26 & 17 & 14 \\
\hline Gibbonsia spp. & 1 & 0 & 0 & 0 & 0 & 0 & 0 & 0 & 1 & 0 \\
\hline Girella nigricans & 53 & 27 & 39 & 18 & 28 & 48 & 105 & 23 & 45 & 26 \\
\hline Halichoeres semicinctus & 0 & 0 & 4 & 2 & 0 & 0 & 2 & 0 & 0 & 2 \\
\hline Hypsurus caryi & 0 & 0 & 3 & 2 & 8 & 3 & 33 & 10 & 2 & 2 \\
\hline Hypsypops rubicundus & $17(4)$ & 14 & $23(1)$ & 18 & $26(1)$ & 17 & 28 & 18 & 33 & 26 \\
\hline Medialuna californiensis & 43 & 55 & 70 & 13 & 14 & 31 & 9 & 8 & 10 & 8 \\
\hline Mycterperca xenarcha & 0 & 0 & 0 & 0 & 0 & 0 & 1 & 0 & 0 & 0 \\
\hline Neoclinus spp. & 0 & 0 & 0 & 0 & 1 & 0 & 0 & 0 & 0 & 0 \\
\hline Ophiodon elongatus & 3 & 0 & 1 & 2 & 0 & 0 & 0 & 0 & 0 & 0 \\
\hline Oxyjulis californica & 3,742 & $1,816(57)$ & 1,068 & 237 & $622(125)$ & 548 & 239 & 683 & 130 & 137 \\
\hline Oxylebius pictus & 74 & $50(1)$ & 46 & 13 & 25 & 11 & 46 & 12 & 34 & 37 \\
\hline Paralabrax clathratus & 111 & $41(29)$ & 69 & 3 & 40 & 48 & 38 & 26 & 48 & 26 \\
\hline Rhacochilus toxotes & 7 & 0 & 1 & 1 & 1 & 0 & 7 & 1 & 1 & 1 \\
\hline Rhacochilus vacca & 17 & 6 & 27 & 8 & 17 & 10 & 13 & 13 & 14 & 5 \\
\hline Sardinops sagax & 0 & 0 & 170 & 0 & 0 & 0 & 0 & 0 & 0 & 0 \\
\hline Scomber japonicus & 40 & 0 & 0 & 5 & 0 & 0 & 0 & 0 & 0 & 0 \\
\hline Scorpaenichthys marmoratus & 6 & 2 & 6 & 1 & 1 & 1 & 0 & 1 & 0 & 1 \\
\hline Sebastes atrovirens & 49 & $73(27)$ & 108 & 17 & 64 & 24 & 38 & 23 & 35 & 41 \\
\hline Sebastes auriculatus & 0 & 1 & 0 & 0 & 0 & 0 & 0 & 0 & 0 & 0 \\
\hline Sebastes carnatus & 0 & $3(2)$ & 1 & 0 & 1 & 0 & 0 & 2 & 0 & 0 \\
\hline Sebastes caurinus & 2 & 1 & 3 & 2 & 3 & 1 & 1 & 0 & 1 & 0 \\
\hline Sebastes chrysomelas & 25 & 16 & 22 & 8 & 10 & 5 & 6 & 2 & 2 & 11 \\
\hline Sebastes melanops & 0 & 0 & 0 & 2 & 0 & 0 & 0 & 0 & 0 & 0 \\
\hline Sebastes mystinus & 195 & $101(3)$ & 392 & 144 & 183 & 279 & $177(120)$ & 190 & 81 & 133 \\
\hline Sebastes rastrelliger & 2 & 7 & 2 & 2 & 2 & 0 & 0 & 1 & 0 & 0 \\
\hline Sebastes serranoides & 144 & $100(28)$ & 272 & 38 & $77(9)$ & 47 & $96(95)$ & 115 & 89 & 74 \\
\hline Sebastes serriceps & 6 & 1 & 5 & 4 & $2(2)$ & 1 & 4 & $0(1)$ & 1 & 2 \\
\hline Semicossyphus pulcher (f) & $57(6)$ & $51(49)$ & $177(17)$ & $87(3)$ & $138(2)$ & $110(1)$ & 141 & 162 & 141 & 118 \\
\hline Semicossyphus pulcher (m) & 22 & 37 & 30 & 14 & 13 & 7 & 15 & 28 & 23 & 24 \\
\hline
\end{tabular}




\section{Daytona 100}

Mean counts of some of the most dynamic swath-counted species at Daytona 100 are shown for the last 5-year period in figure 32. At this site, the two common sea urchin species have opposite trajectories in year 5. Strongylocentrotus purpuratus has reached mean densities of greater than 1,000 per $20-\mathrm{m}^{2}$ swath, which is the highest in the 5 years that the combined supersite has been sampled, whereas $S$. franciscanus has declined to its lowest density, at less than 50 per swath. The supersite still maintains patches of urchin dominated and kelp dominated areas. Purple urchins remained the most common swath-counted organism at Daytona 100, whereas red urchins were replaced as second most abundant by the fucoid, C. osmundacea, in spring 2019 (table 26). Cystoseira osmundacea has more than doubled in density during the last 2 years, whereas the understory kelp Eisenia arborea has fallen to less than 25 percent of densities it had in 2014-17. Of the other understory kelps, $P$. californica declined by about half in year 5, but the density of Laminaria spp. remained about the same. Finally, the wavy turban snail, M. undosa, similar to its trend at West End and Dutch Harbor, has been gradually increasing during the last couple of years.

In spring 2019, the density of $M$. pyrifera fell to its lowest level in the 5-year sampling history of Daytona 100. Based on the stipe counts and holdfast diameters recorded there (figs. 33, 34), the remaining population was composed primarily of medium aged plants. Unlike in some previous sampling periods, there were no holdfast diameters less than $10 \mathrm{~cm}$ or greater than $50 \mathrm{~cm}$.

A summary of the density and sizes of non-echinoid invertebrate species observed at Daytona 100 is shown in table 27. Kellet's whelk ( $K$. kelletii) followed a recruitment pattern similar to that seen at Nav Fac 100 (compare fig. 35 to fig. 17). At Daytona 100, however, the apparent recruitment was in spring 2016 rather than in fall 2015. At both locations, there appeared to be another recruitment in spring 2018, but at Daytona 100, subsequent size distributions looked more like possible growth, whereas Nav Fac 100 may have had another recruitment pulse in spring 2019.
As mentioned earlier, wavy turban snail (M. undosa) densities continued to increase to record levels. No recruitment class is evident in the size frequency plots, however (fig. 36). The distribution from this supersite is skewed more toward larger individuals than that from Nav Fac 100.

The orange puffball sponge ( $T$. aurantia) continued to be the only species consistently counted in 1- $\mathrm{m}^{2}$ quadrats (table 28). The gastropod K. kelletii, though not observed in quadrats the previous year, was the only other invertebrate counted in quadrats in year 5 .

There appear to be several modes in the Daytona 100 purple urchin size data (fig. 37). Like Nav Fac 100, this supersite had high proportions of small size classes and consistently low numbers of larger urchins (table 10). The size distribution of red urchins, whose density declined, has changed considerably in the last few years. It has followed a pattern seen at several of the sites of condensing the distribution into the middle sizes, with few small or large individuals (fig. 38). This pattern also is apparent in the decreased proportions in the largest and smallest size bins in table 11.

Encrusting coralline algae was again the most common cover species in year 5 , with the brown alga $D$. binghamiae remaining the second most common (table 29). In fall 2018, the small holothurian P. rubra was the third most common, but in spring 2019, it was surpassed by increasing cover of $C$. osmundacea and bare substrate. Cover categories throughout time, as shown in figure 21, indicated a continuation of the trend observed in year 4 of increasing cover of brown algae (primarily $D$. binghamiae and C. osmundacea) and decreasing cover of fleshy red algae.

Daytona 100 was similar to West End in number of fish species but ranked second (after Dutch Harbor) for benthic, midwater, and overall fish density (table 14). Most of the fish counted there were of the schooling species blacksmith (C. punctipinnis) and señorita (O. californica), but kelp bass (P. clathratus) and sheephead (S. pulcher) continued to be fairly common (table 30 ). The east-heading transects at this site begin in an urchin barren but continue through an area of flat bottom but kelp-rich habitat, which typically features few fish. The final $10 \mathrm{~m}$ of these transects incorporate a high relief reef, where the majority of fish are observed. 


\section{Dynamic swath counted species mean count / $20 \mathrm{~m}^{2}$ - Daytona 100}

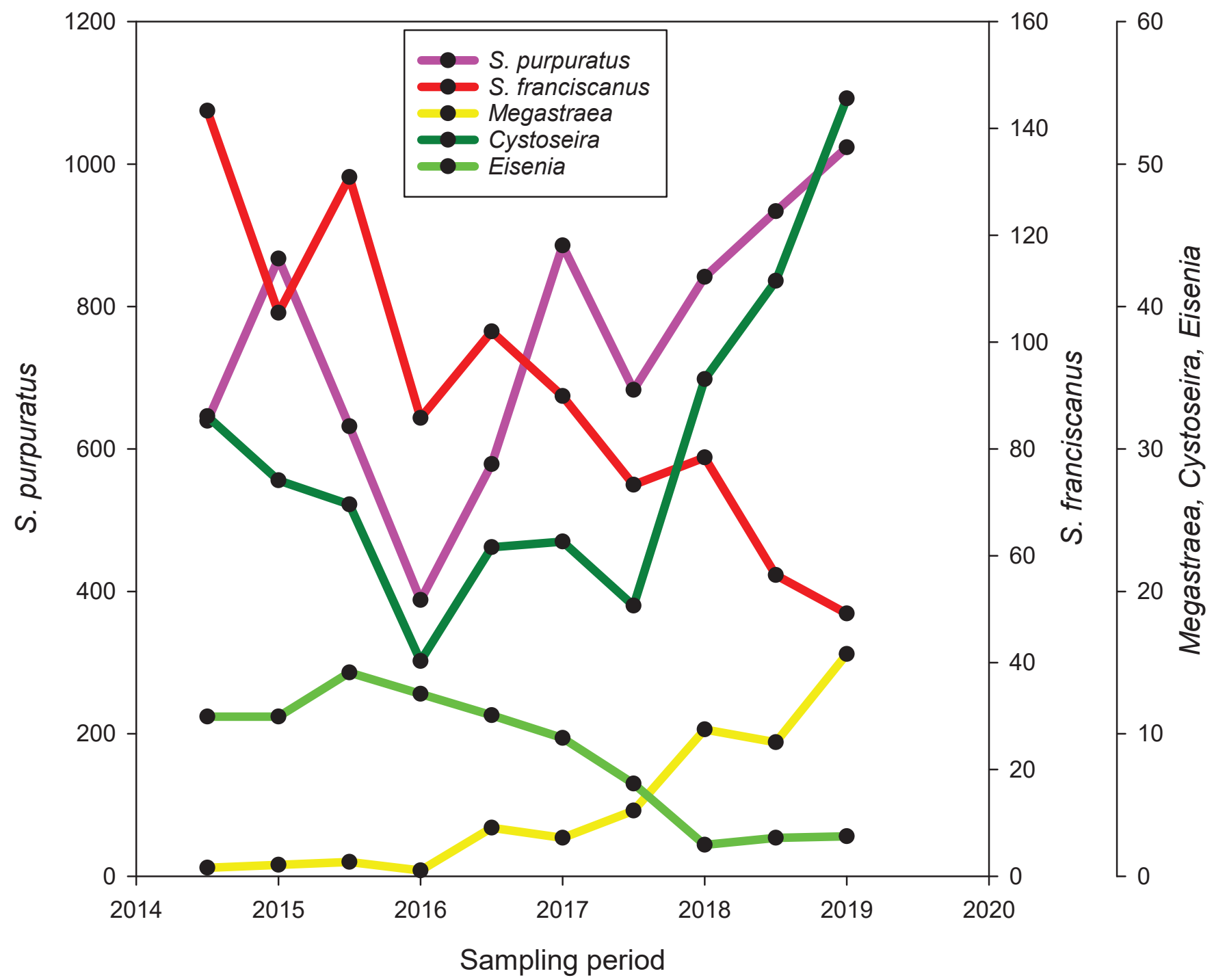

Figure 32. Mean densities of some swath-counted species that have demonstrated changing abundance at Daytona 100 during the last 5 years. [Note three vertical axes for densities of different species groups]

Table 26. Daytona 100 mean (standard deviation) swath counts for fall 2014 through spring 2019 expressed as individuals per 20-square meter transect.

$[>$, greater than; $\mathrm{m}$, meter; $<$, less than $]$

\begin{tabular}{|c|c|c|c|c|c|c|c|c|c|c|}
\hline Species name & Fall 2014 & $\begin{array}{c}\text { Spring } \\
2015\end{array}$ & Fall 2015 & $\begin{array}{c}\text { Spring } \\
2016\end{array}$ & Fall 2016 & $\begin{array}{c}\text { Spring } \\
2017\end{array}$ & Fall 2017 & $\begin{array}{c}\text { Spring } \\
2018\end{array}$ & Fall 2018 & $\begin{array}{c}\text { Spring } \\
2019\end{array}$ \\
\hline Aplysia californica & $\begin{array}{c}0.1 \\
(0.32)\end{array}$ & $\begin{array}{c}0 \\
(0.00)\end{array}$ & $\begin{array}{c}0 \\
(0.00)\end{array}$ & $\begin{array}{c}0.1 \\
(0.32)\end{array}$ & $\begin{array}{c}1.6 \\
(2.27)\end{array}$ & $\begin{array}{c}0 \\
(0.00)\end{array}$ & $\begin{array}{c}0.5 \\
(0.97)\end{array}$ & $\begin{array}{c}0 \\
(0.00)\end{array}$ & $\begin{array}{c}0.30 \\
(0.95)\end{array}$ & $\begin{array}{c}0 \\
(0.00)\end{array}$ \\
\hline Astrometis sertulifera & $\begin{array}{c}0 \\
(0.00)\end{array}$ & $\begin{array}{c}0 \\
(0.00)\end{array}$ & $\begin{array}{c}0 \\
(0.00)\end{array}$ & $\begin{array}{c}0 \\
(0.00)\end{array}$ & $\begin{array}{c}0 \\
(0.00)\end{array}$ & $\begin{array}{c}0 \\
(0.00)\end{array}$ & $\begin{array}{c}0 \\
(0.00)\end{array}$ & $\begin{array}{c}0 \\
(0.00)\end{array}$ & $\begin{array}{c}0 \\
(0.00)\end{array}$ & $\begin{array}{c}0 \\
(0.00)\end{array}$ \\
\hline Crassadoma gigantea & $\begin{array}{c}2.4 \\
(4.65)\end{array}$ & $\begin{array}{c}0.5 \\
(0.97)\end{array}$ & $\begin{array}{c}1.7 \\
(2.45)\end{array}$ & $\begin{array}{c}0.9 \\
(1.73)\end{array}$ & $\begin{array}{c}1.7 \\
(4.08)\end{array}$ & $\begin{array}{c}2.2 \\
(3.85)\end{array}$ & $\begin{array}{c}2.2 \\
(3.46)\end{array}$ & $\begin{array}{c}2.7 \\
(4.85)\end{array}$ & $\begin{array}{c}2.70 \\
(4.30)\end{array}$ & $\begin{array}{c}3.30 \\
(3.95)\end{array}$ \\
\hline
\end{tabular}


Table 26. Daytona 100 mean (standard deviation) swath counts for fall 2014 through spring 2019 expressed as individuals per 20 -square meter transect.-Continued

$[>$, greater than; $\mathrm{m}$, meter; $<$, less than]

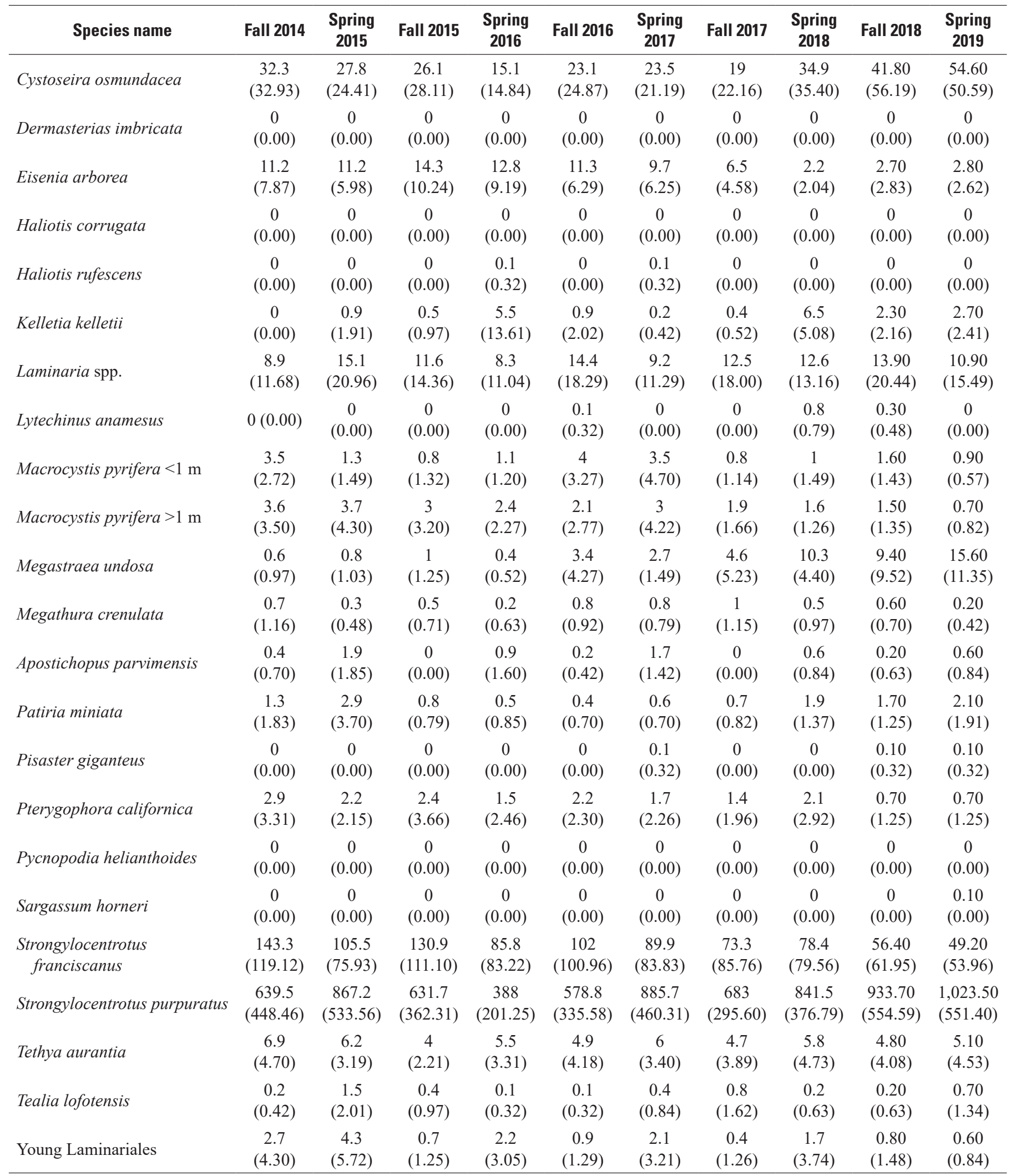


Macrocystis pyrifera stipe counts - Daytona 100
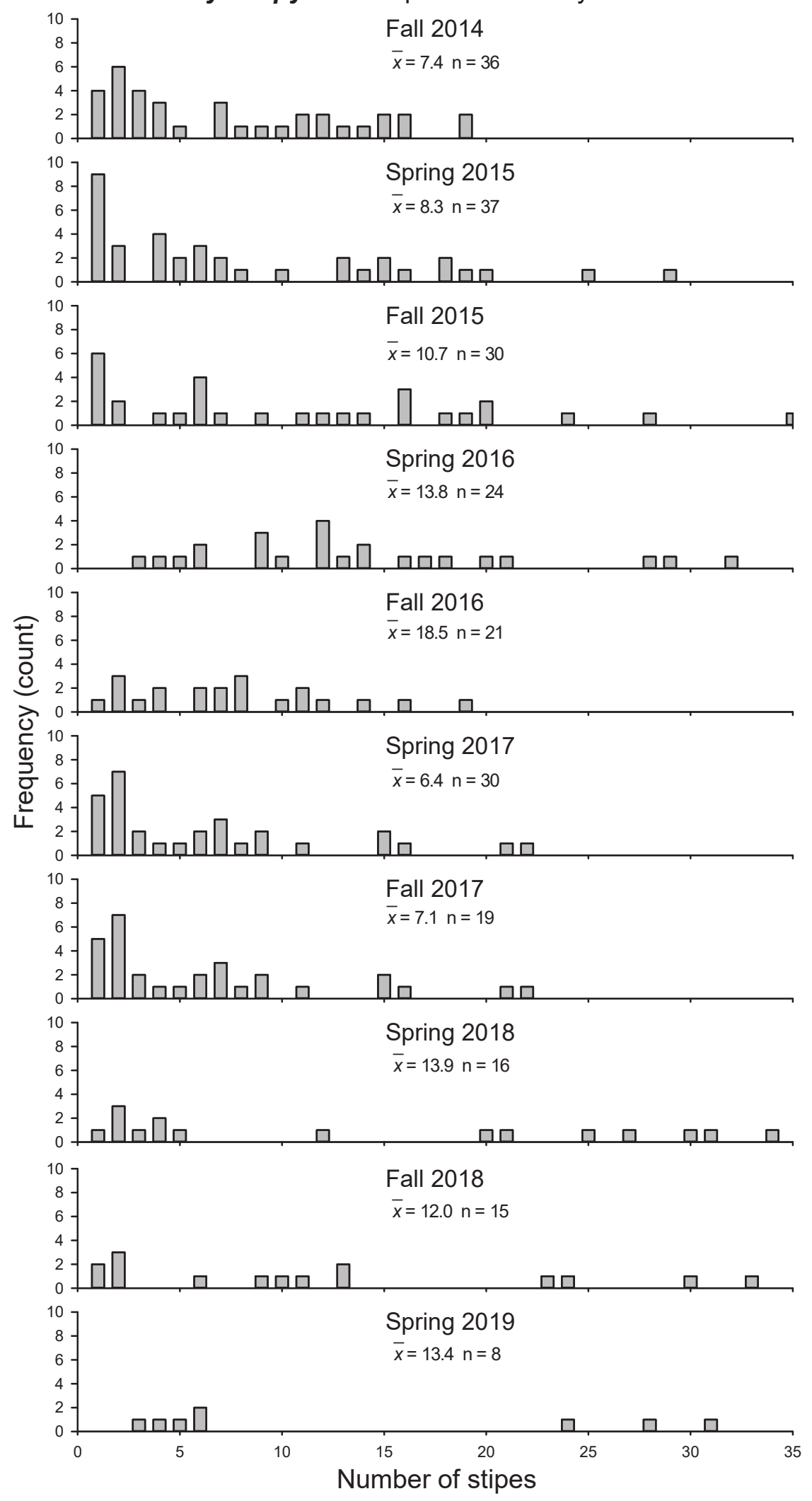

Figure 33. Daytona 100 Macrocystis pyrifera greater than 1-meter (m) tall stipe counts by season in fall 2014-spring 2019. [ $\bar{x}$ is mean count, $\mathrm{n}$ is number of individuals.] 
Macrocystis pyrifera holdfast diameters - Daytona 100
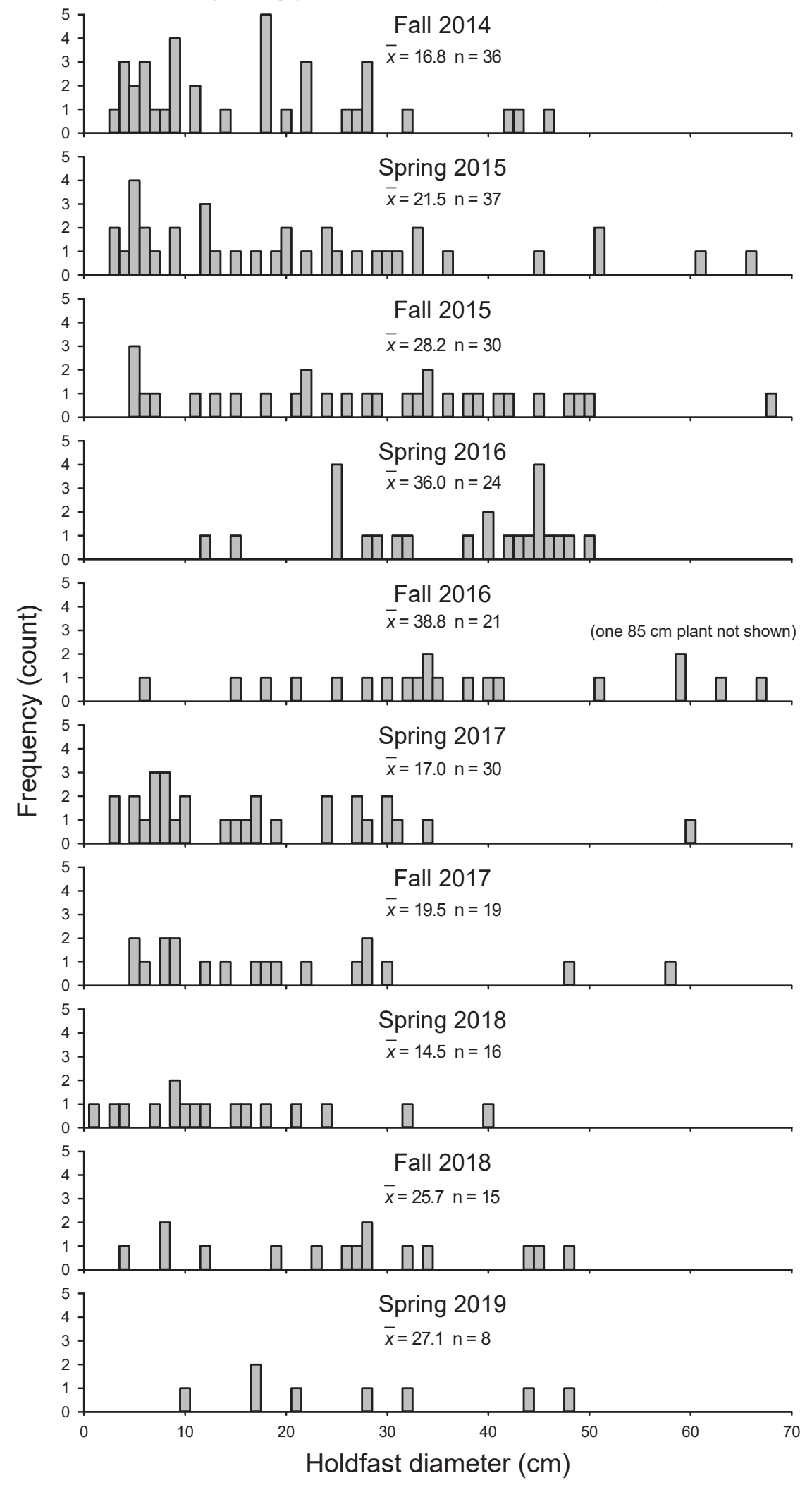

Figure 34. Daytona 100 Macrocystis pyrifera greater than 1-meter $(\mathrm{m})$ tall holdfast diameters by season, fall 2014-spring 2019. [ $\bar{x}$ is mean diameter, $\mathrm{n}$ is number of individuals] 
Table 27. Sizes of invertebrates measured on swaths at Daytona 100 in fall 2014 through spring 2019.

[Strongylocentrotus spp. excluded. See figures 37 and 38 for purple and red urchin size data. Abbreviations: N, sample size; Min, minimum; - , no data; Max, maximum]

\begin{tabular}{|c|c|c|c|c|c|c|c|c|}
\hline \multirow[b]{2}{*}{ Size } & \multicolumn{8}{|c|}{ Species name } \\
\hline & $\begin{array}{c}\text { Crassadoma } \\
\text { gigantea }\end{array}$ & $\begin{array}{c}\text { Haliotis } \\
\text { refescens }\end{array}$ & $\begin{array}{c}\text { Kelletia } \\
\text { kelletii }\end{array}$ & $\begin{array}{l}\text { Lytechinus } \\
\text { anamesus }\end{array}$ & $\begin{array}{c}\text { Megastraea } \\
\text { undosa }\end{array}$ & $\begin{array}{c}\text { Megathura } \\
\text { crenulata }\end{array}$ & $\begin{array}{l}\text { Patiria } \\
\text { miniata }\end{array}$ & $\begin{array}{c}\text { Pisaster } \\
\text { giganteus }\end{array}$ \\
\hline \multicolumn{9}{|c|}{ Year 1: Fall 2014} \\
\hline $\mathrm{N}$ & 23 & 0 & 0 & 0 & 6 & 6 & 13 & 0 \\
\hline Min & 22 & - & - & - & 38 & 18 & 48 & - \\
\hline Max & 101 & - & - & - & 90 & 100 & 101 & - \\
\hline Mean & 52.3 & - & - & - & 65.0 & 80.3 & 64.0 & - \\
\hline \multicolumn{9}{|c|}{ Year 1: Spring 2015} \\
\hline $\mathrm{N}$ & 5 & 0 & 9 & 0 & 8 & 3 & 29 & 0 \\
\hline Min & 60 & - & 35 & - & 30 & 120 & 32 & - \\
\hline Max & 180 & - & 110 & - & 130 & 193 & 94 & - \\
\hline Mean & 97.0 & - & 60.8 & - & 86.1 & 151.0 & 59.8 & - \\
\hline \multicolumn{9}{|c|}{ Year 2: Fall 2015} \\
\hline $\mathrm{N}$ & 17 & 0 & 5 & 0 & 10 & 5 & 7 & 0 \\
\hline Min & 24 & - & 38 & - & 44 & 50 & 37 & - \\
\hline Max & 170 & - & 135 & - & 85 & 120 & 86 & - \\
\hline Mean & 74.6 & - & 68.6 & - & 59.3 & 86.0 & 66.7 & - \\
\hline \multicolumn{9}{|c|}{ Year 2: Spring 2016} \\
\hline $\mathrm{N}$ & 9 & 1 & 34 & 0 & 4 & 2 & 5 & 0 \\
\hline Min & 42 & 50 & 25 & - & 45 & 70 & 25 & - \\
\hline Max & 95 & 50 & 120 & - & 68 & 80 & 70 & - \\
\hline Mean & 67.7 & 50.0 & 46.1 & - & 56.6 & 75.0 & 49.8 & - \\
\hline \multicolumn{9}{|c|}{ Year 3: Fall 2016} \\
\hline $\mathrm{N}$ & 17 & 0 & 9 & 0 & 34 & 8 & 4 & 0 \\
\hline Min & 27 & - & 21 & - & 16 & 82 & 50 & - \\
\hline Max & 88 & - & 123 & - & 106 & 130 & 80 & - \\
\hline Mean & 65.6 & - & 50.3 & - & 57.6 & 100.6 & 67.0 & - \\
\hline \multicolumn{9}{|c|}{ Year 3: Spring 2017} \\
\hline $\mathrm{N}$ & 23 & 1 & 2 & 0 & 27 & 8 & 7 & 1 \\
\hline Min & 30 & 40 & 22 & - & 23 & 78 & 36 & 75 \\
\hline Max & 140 & 40 & 50 & - & 120 & 110 & 61 & 75 \\
\hline Mean & 78.4 & 40.0 & 36.0 & - & 62.7 & 96.5 & 52.3 & 75.0 \\
\hline \multicolumn{9}{|c|}{ Year 4: Fall 2017} \\
\hline $\mathrm{N}$ & 22 & 0 & 5 & 0 & 47 & 10 & 9 & 0 \\
\hline Min & 38 & - & 38 & - & 38 & 43 & 35 & - \\
\hline Max & 154 & - & 112 & - & 93 & 103 & 100 & - \\
\hline Mean & 83.3 & - & 73.8 & - & 64.3 & 88.2 & 62.3 & - \\
\hline \multicolumn{9}{|c|}{ Year 4: Spring 2018} \\
\hline $\mathrm{N}$ & 27 & 0 & 65 & 8 & 103 & 5 & 20 & 0 \\
\hline Min & 28 & - & 4 & 16 & 21 & 68 & 22 & - \\
\hline Max & 110 & - & 81 & 38 & 108 & 114 & 82 & - \\
\hline Mean & 60.4 & - & 42.7 & 25.6 & 65.8 & 92.4 & 53.7 & - \\
\hline
\end{tabular}


72 Kelp Forest Monitoring at Naval Base Ventura County, San Nicolas Island, California

Table 27. Sizes of invertebrates measured on swaths at Daytona 100 in fall 2014 through spring 2019.-Continued

[Strongylocentrotus spp. excluded. See figures 37 and 38 for purple and red urchin size data. Abbreviations: N, sample size; Min, minimum; - , no data; Max, maximum]

\begin{tabular}{|c|c|c|c|c|c|c|c|c|}
\hline \multirow[b]{2}{*}{ Size } & \multicolumn{8}{|c|}{ Species name } \\
\hline & $\begin{array}{c}\text { Crassadoma } \\
\text { gigantea }\end{array}$ & $\begin{array}{c}\text { Haliotis } \\
\text { refescens }\end{array}$ & $\begin{array}{r}\text { Kelletia } \\
\text { kelletii }\end{array}$ & $\begin{array}{l}\text { Lytechinus } \\
\text { anamesus }\end{array}$ & $\begin{array}{c}\text { Megastraea } \\
\text { undosa }\end{array}$ & $\begin{array}{c}\text { Megathura } \\
\text { crenulata }\end{array}$ & $\begin{array}{l}\text { Patiria } \\
\text { miniata }\end{array}$ & $\begin{array}{c}\text { Pisaster } \\
\text { giganteus }\end{array}$ \\
\hline \multicolumn{9}{|c|}{ Year 5: Fall 2018} \\
\hline $\mathrm{N}$ & 27 & 0 & 23 & 0 & 94 & 6 & 17 & 1 \\
\hline Min & 20 & - & 31 & - & 32 & 88 & 34 & 78 \\
\hline Max & 152 & - & 111 & - & 101 & 98 & 82 & 78 \\
\hline Mean & 82.3 & - & 55.7 & - & 65.8 & 93.3 & 63.1 & 78.0 \\
\hline \multicolumn{9}{|c|}{ Year 5: Spring 2019} \\
\hline $\mathrm{N}$ & 33 & 0 & 27 & 0 & 156 & 2 & 15 & 1 \\
\hline Min & 40 & - & 31 & - & 24 & 91 & 25 & 92 \\
\hline Max & 180 & - & 91 & - & 101 & 121 & 84 & 92 \\
\hline Mean & 83.3 & - & 63.9 & - & $? ?$ & 106.0 & 57.3 & 92.0 \\
\hline
\end{tabular}




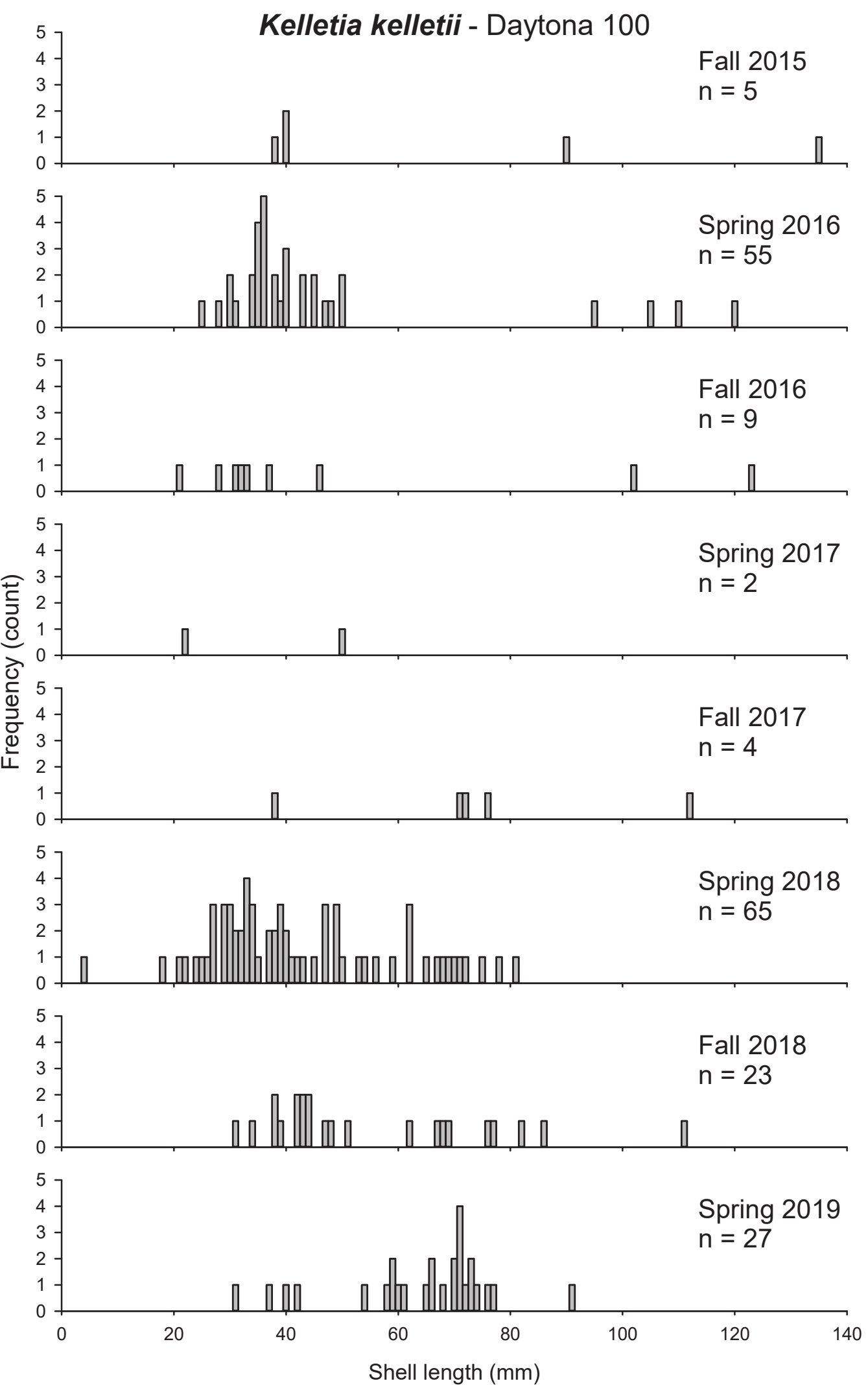

Figure 35. Size structure of Kellet's whelk (Kelletia kelletii) at Daytona 100 in fall 2014-spring 2019. [n= number of individuals] 

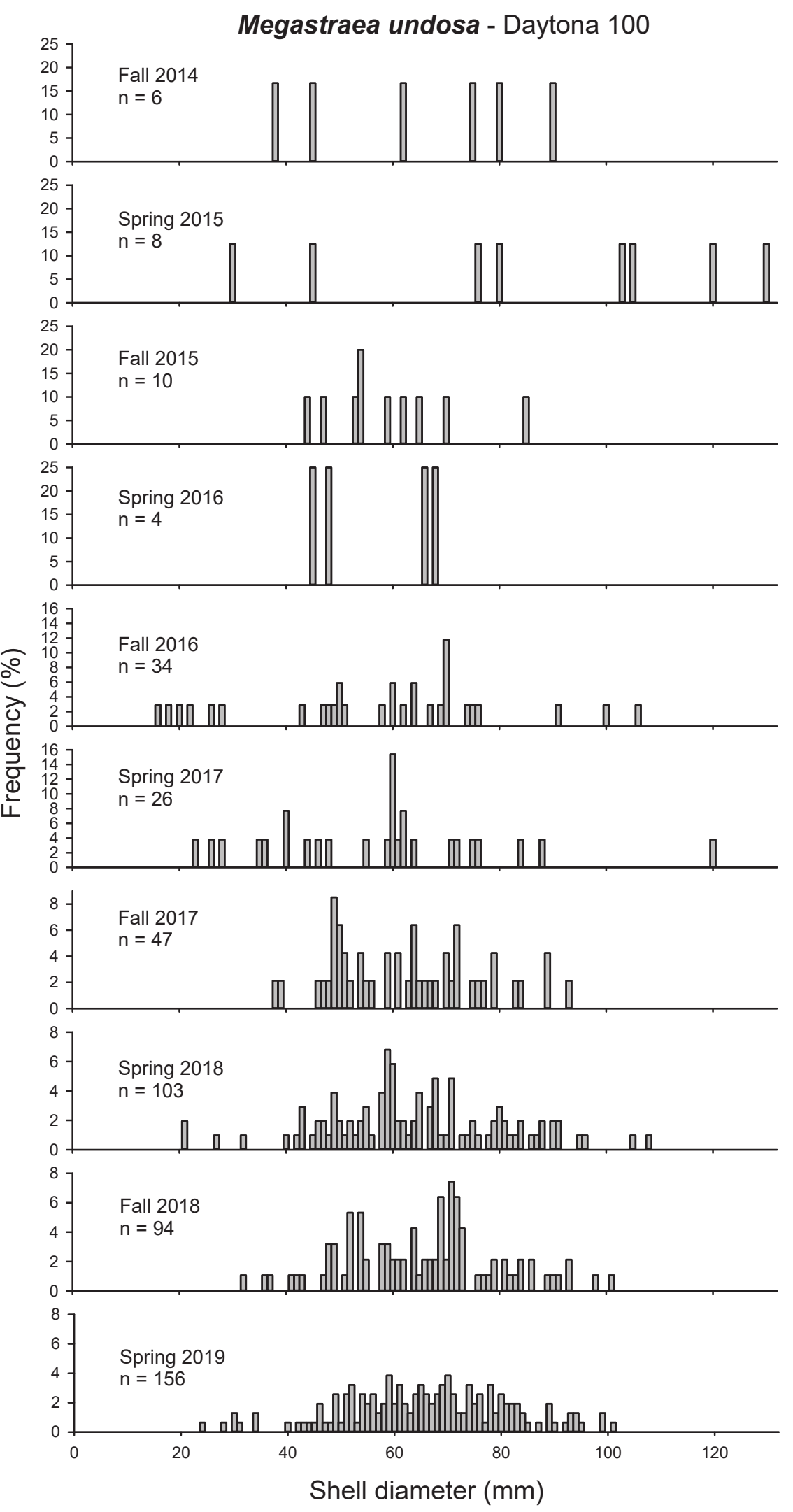

Figure 36. Daytona 100 size structure of wavy turban snails (Megastraea undosa) in fall 2014-spring 2019. [Note different frequency scales, $n=$ number of individuals] 
Table 28. Mean (and standard deviation) numbers of rare species counted on twenty 1-square meter quadrats from Daytona 100 in fall 2014 through spring 2019.

\begin{tabular}{|c|c|c|c|c|c|c|c|c|c|c|}
\hline Species name & $\begin{array}{l}\text { Fall } \\
2014\end{array}$ & $\begin{array}{c}\text { Spring } \\
2015\end{array}$ & $\begin{array}{l}\text { Fall } \\
2015\end{array}$ & $\begin{array}{c}\text { Spring } \\
2016\end{array}$ & $\begin{array}{c}\text { Fall } \\
2016\end{array}$ & $\begin{array}{c}\text { Spring } \\
2017\end{array}$ & $\begin{array}{l}\text { Fall } \\
2017\end{array}$ & $\begin{array}{c}\text { Spring } \\
2018\end{array}$ & $\begin{array}{l}\text { Fall } \\
2018\end{array}$ & $\begin{array}{c}\text { Spring } \\
2019\end{array}$ \\
\hline Lithopoma gibberosa & $\begin{array}{c}0.0 \\
(0.00)\end{array}$ & $\begin{array}{c}0.0 \\
(0.00)\end{array}$ & $\begin{array}{c}0.0 \\
(0.00)\end{array}$ & $\begin{array}{c}0.0 \\
(0.00)\end{array}$ & $\begin{array}{c}0.0 \\
(0.00)\end{array}$ & $\begin{array}{c}0.0 \\
(0.00)\end{array}$ & $\begin{array}{c}0.0 \\
(0.00)\end{array}$ & $\begin{array}{c}0.0 \\
(0.00)\end{array}$ & $\begin{array}{c}0.0 \\
(0.00)\end{array}$ & $\begin{array}{c}0.0 \\
(0.00)\end{array}$ \\
\hline Cypraea spadicea & $\begin{array}{c}0.0 \\
(0.00)\end{array}$ & $\begin{array}{c}0.0 \\
(0.00)\end{array}$ & $\begin{array}{c}0.1 \\
(0.22)\end{array}$ & $\begin{array}{c}0.0 \\
(0.00)\end{array}$ & $\begin{array}{c}0.2 \\
(0.37)\end{array}$ & $\begin{array}{c}0.0 \\
(0.00)\end{array}$ & $\begin{array}{c}0.1 \\
(0.22)\end{array}$ & $\begin{array}{c}0.0 \\
(0.00)\end{array}$ & $\begin{array}{c}0.0 \\
(0.00)\end{array}$ & $\begin{array}{c}0.0 \\
(0.00)\end{array}$ \\
\hline Kelletia kelletii & $\begin{array}{c}0.0 \\
(0.00)\end{array}$ & $\begin{array}{c}0.0 \\
(0.00)\end{array}$ & $\begin{array}{c}0.0 \\
(0.00)\end{array}$ & $\begin{array}{c}0.0 \\
(0.00)\end{array}$ & $\begin{array}{c}0.1 \\
(0.31)\end{array}$ & $\begin{array}{c}0.1 \\
(0.22)\end{array}$ & $\begin{array}{c}0.0 \\
(0.00)\end{array}$ & $\begin{array}{c}0.0 \\
(0.00)\end{array}$ & $\begin{array}{c}0.0 \\
(0.00)\end{array}$ & $\begin{array}{c}0.1 \\
(0.37)\end{array}$ \\
\hline Norrisia norrisi & $\begin{array}{c}0.0 \\
(0.00)\end{array}$ & $\begin{array}{c}0.1 \\
(0.22)\end{array}$ & $\begin{array}{c}0.0 \\
(0.00)\end{array}$ & $\begin{array}{c}0.1 \\
(0.22)\end{array}$ & $\begin{array}{c}0.0 \\
(0.00)\end{array}$ & $\begin{array}{c}0.1 \\
(0.22)\end{array}$ & $\begin{array}{c}0.2 \\
(0.49)\end{array}$ & $\begin{array}{c}0.1 \\
(0.31)\end{array}$ & $\begin{array}{c}0.0 \\
(0.00)\end{array}$ & $\begin{array}{c}0.0 \\
(0.00)\end{array}$ \\
\hline Sargassum horneri & $\begin{array}{c}0.0 \\
(0.00)\end{array}$ & $\begin{array}{c}0.0 \\
(0.00)\end{array}$ & $\begin{array}{c}0.0 \\
(0.00)\end{array}$ & $\begin{array}{c}0.0 \\
(0.00)\end{array}$ & $\begin{array}{c}0.0 \\
(0.00)\end{array}$ & $\begin{array}{c}0.0 \\
(0.00)\end{array}$ & $\begin{array}{c}0.0 \\
(0.00)\end{array}$ & $\begin{array}{c}0.0 \\
(0.00)\end{array}$ & $\begin{array}{c}0.0 \\
(0.00)\end{array}$ & $\begin{array}{c}0.0 \\
(0.00)\end{array}$ \\
\hline Styela montereyensis & $\begin{array}{c}0.0 \\
(0.00)\end{array}$ & $\begin{array}{c}0.0 \\
(0.00)\end{array}$ & $\begin{array}{c}0.0 \\
(0.00)\end{array}$ & $\begin{array}{c}0.1 \\
(0.22)\end{array}$ & $\begin{array}{c}0.0 \\
(0.00)\end{array}$ & $\begin{array}{c}0.0 \\
(0.00)\end{array}$ & $\begin{array}{c}0.0 \\
(0.00)\end{array}$ & $\begin{array}{c}0.0 \\
(0.00)\end{array}$ & $\begin{array}{c}0.0 \\
(0.00)\end{array}$ & $\begin{array}{c}0.0 \\
(0.00)\end{array}$ \\
\hline Tegula regina & $\begin{array}{c}0.0 \\
(0.00)\end{array}$ & $\begin{array}{c}0.0 \\
(0.00)\end{array}$ & $\begin{array}{c}0.0 \\
(0.00)\end{array}$ & $\begin{array}{c}0.0 \\
(0.00)\end{array}$ & $\begin{array}{c}0.0 \\
(0.00)\end{array}$ & $\begin{array}{c}0.0 \\
(0.00)\end{array}$ & $\begin{array}{c}0.0 \\
(0.00)\end{array}$ & $\begin{array}{c}0.0 \\
(0.00)\end{array}$ & $\begin{array}{c}0.0 \\
(0.00)\end{array}$ & $\begin{array}{c}0.0 \\
(0.00)\end{array}$ \\
\hline Tethya aurantia & $\begin{array}{c}0.1 \\
(0.31)\end{array}$ & $\begin{array}{c}0.3 \\
(0.57)\end{array}$ & $\begin{array}{c}0.3 \\
(0.64)\end{array}$ & $\begin{array}{c}0.5 \\
(0.83)\end{array}$ & $\begin{array}{c}0.2 \\
(0.37)\end{array}$ & $\begin{array}{c}0.3 \\
(0.64)\end{array}$ & $\begin{array}{c}0.2 \\
(0.37)\end{array}$ & $\begin{array}{c}0.3 \\
(0.55)\end{array}$ & $\begin{array}{c}0.2 \\
(0.57)\end{array}$ & $\begin{array}{c}0.2 \\
(0.37)\end{array}$ \\
\hline Tealia lofotensis & $\begin{array}{c}0.0 \\
(0.00)\end{array}$ & $\begin{array}{c}0.0 \\
(0.00)\end{array}$ & $\begin{array}{c}0.0 \\
(0.00)\end{array}$ & $\begin{array}{c}0.0 \\
(0.00)\end{array}$ & $\begin{array}{c}0.0 \\
(0.00)\end{array}$ & $\begin{array}{c}0.0 \\
(0.00)\end{array}$ & $\begin{array}{c}0.0 \\
(0.00)\end{array}$ & $\begin{array}{c}0.0 \\
(0.00)\end{array}$ & $\begin{array}{c}0.0 \\
(0.00)\end{array}$ & $\begin{array}{c}0.0 \\
(0.00)\end{array}$ \\
\hline
\end{tabular}


Strongylocentrotus purpuratus - Daytona 100

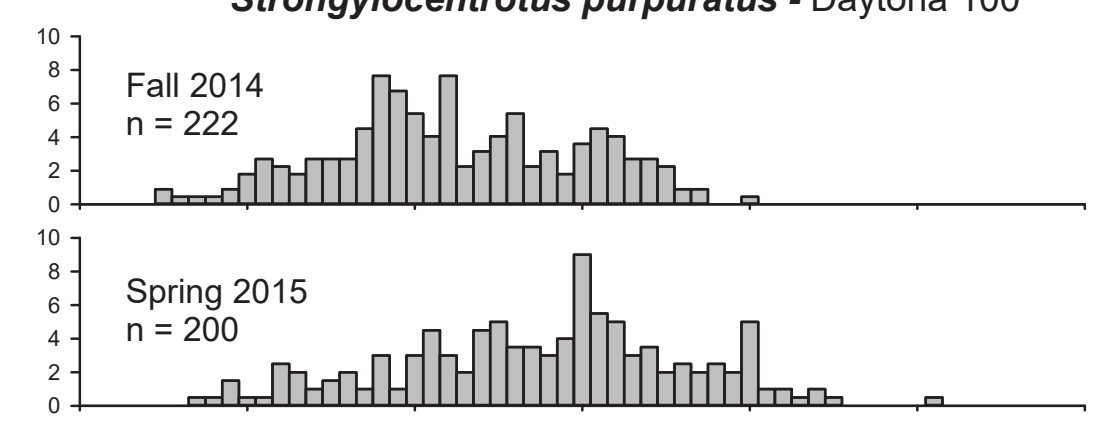

Fall 2015

$\mathrm{n}=205$

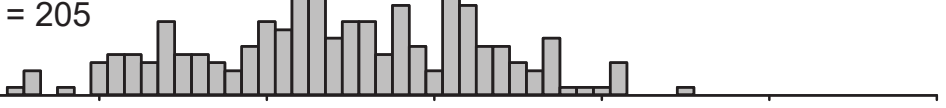

Spring 2016

$\mathrm{n}=219$
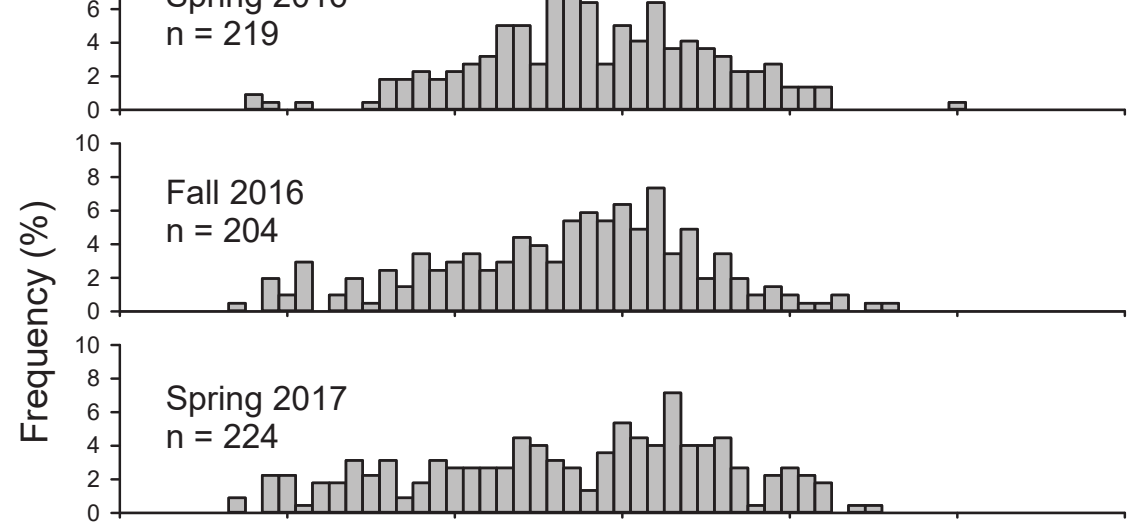

10
8
6 $\quad$ Fall 2017

$\mathrm{n}=205$

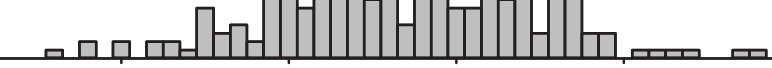

Spring 2018

$\mathrm{n}=327$

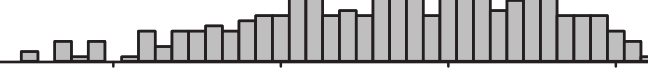

Fall 2018

$\mathrm{n}=210$

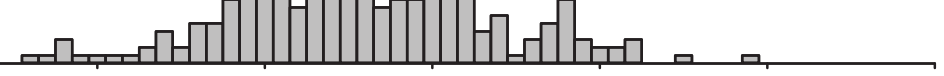

$\left.\begin{array}{r}10 \\ 8 \\ 6\end{array}\right] \quad$ Spring 2019

$\mathrm{n}=217$

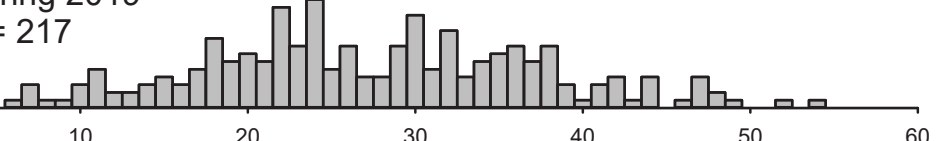

Test diameter $(\mathrm{mm})$

Figure 37. Daytona 100 size structure of purple urchins (Strongylocentrotus purpuratus) in fall 2014-spring 2019. [ $n$ = number of individuals] 
Strongylocentrotus franciscanus - Daytona 100
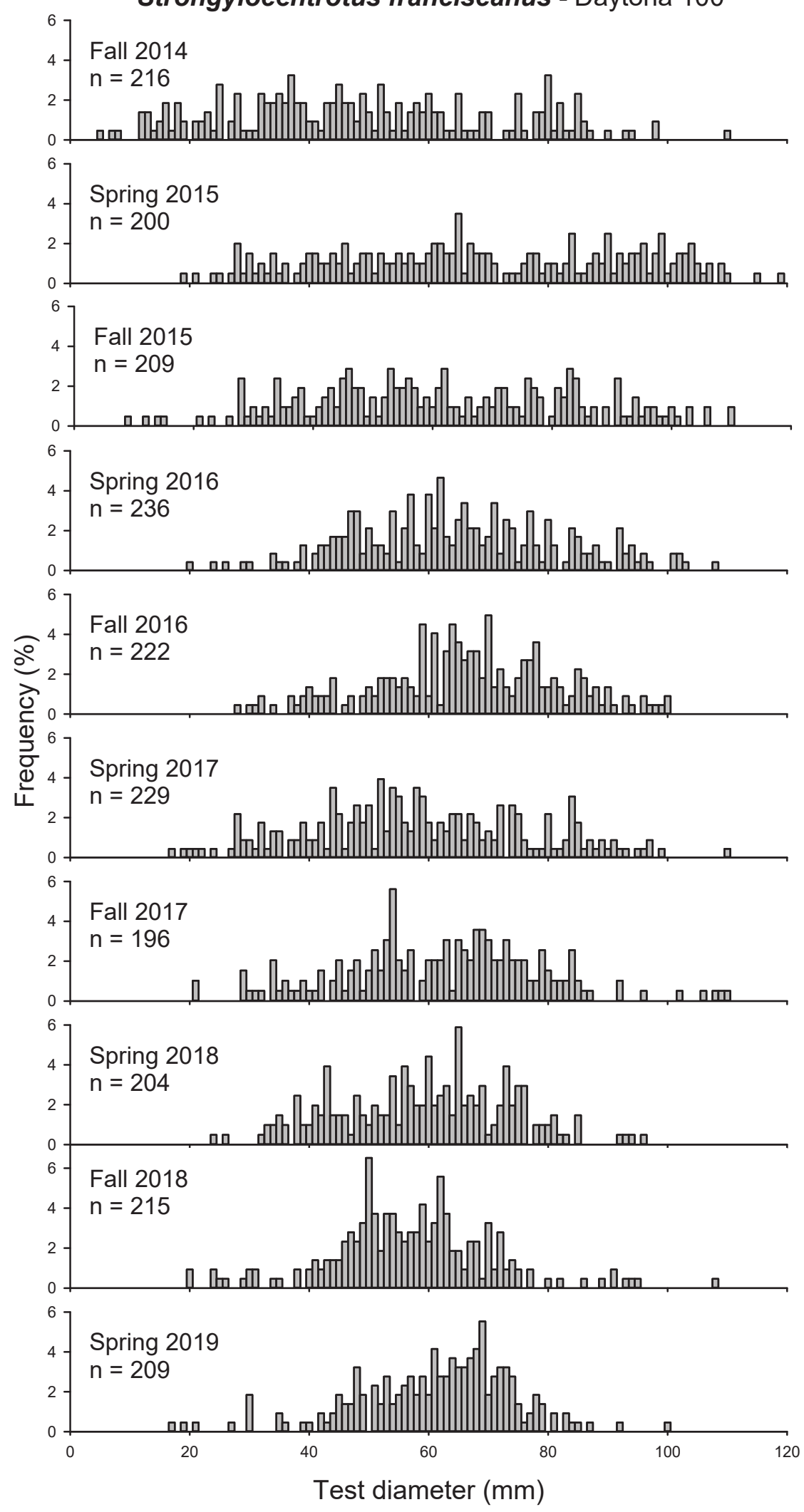

Figure 38. Daytona 100 size structure of red urchins (Strongylocentrotus franciscanus) in fall 2014-spring 2019. [ $\mathrm{n}=$ number of individuals] 
Table 29. Daytona 100 point contact “species" ranked by the sum of points for fall 2014 through spring 2019.

$[>$, greater than; $\mathrm{m}$, meter; $<$, less than]

\begin{tabular}{|c|c|c|c|c|c|c|c|c|c|c|}
\hline Species name & $\begin{array}{l}\text { Fall } \\
2014\end{array}$ & $\begin{array}{c}\text { Spring } \\
2015\end{array}$ & $\begin{array}{l}\text { Fall } \\
2015\end{array}$ & $\begin{array}{c}\text { Spring } \\
2016\end{array}$ & $\begin{array}{l}\text { Fall } \\
2016\end{array}$ & $\begin{array}{c}\text { Spring } \\
2017\end{array}$ & $\begin{array}{l}\text { Fall } \\
2017\end{array}$ & $\begin{array}{c}\text { Spring } \\
2018\end{array}$ & $\begin{array}{l}\text { Fall } \\
2018\end{array}$ & $\begin{array}{c}\text { Spring } \\
2019\end{array}$ \\
\hline Encrusting coralline algae & 188 & 173 & 241 & 206 & 225 & 249 & 269 & 292 & 276 & 230 \\
\hline Dictyota binghamiae & 26 & 42 & 27 & 90 & 59 & 38 & 75 & 115 & 52 & 136 \\
\hline Pachythyone rubra & 23 & 41 & 13 & 16 & 23 & 37 & 113 & 35 & 39 & 10 \\
\hline Bare substratum & 39 & 34 & 33 & 15 & 32 & 21 & 37 & 15 & 27 & 58 \\
\hline Sand & 26 & 40 & 32 & 30 & 19 & 30 & 15 & 27 & 33 & 37 \\
\hline Cystoseira osmundacea & 19 & 27 & 20 & 24 & 24 & 15 & 17 & 24 & 26 & 65 \\
\hline Cryptopleura spp. & 27 & 25 & 31 & 46 & 66 & 25 & 18 & 0 & 5 & 0 \\
\hline Cucumaria piperata & 29 & 28 & 12 & 15 & 40 & 12 & 13 & 24 & 24 & 16 \\
\hline Calliarthron spp. & 29 & 12 & 23 & 26 & 30 & 16 & 21 & 17 & 17 & 19 \\
\hline Laminaria spp. & 8 & 16 & 14 & 8 & 12 & 6 & 26 & 24 & 22 & 12 \\
\hline Pink encrusting bryozoan & 1 & 5 & 12 & 22 & 34 & 21 & 15 & 12 & 9 & 15 \\
\hline Corallina officinalis & 13 & 18 & 11 & 6 & 12 & 20 & 9 & 6 & 13 & 10 \\
\hline Rhodymenia californica & 32 & 16 & 18 & 21 & 16 & 0 & 9 & 1 & 1 & 4 \\
\hline Barnacle & 59 & 51 & 4 & 0 & 0 & 2 & 0 & 0 & 0 & 0 \\
\hline Eisenia arborea & 13 & 14 & 15 & 17 & 15 & 5 & 4 & 5 & 8 & 7 \\
\hline Balanophyllia elegans & 14 & 15 & 11 & 6 & 2 & 7 & 4 & 6 & 6 & 6 \\
\hline Kelp holdfast & 3 & 3 & 8 & 19 & 5 & 12 & 3 & 6 & 10 & 2 \\
\hline Dictyopteris undulata & 1 & 5 & 2 & 6 & 3 & 9 & 2 & 7 & 22 & 10 \\
\hline Serpulorbis squamiger & 7 & 9 & 7 & 4 & 6 & 2 & 5 & 8 & 3 & 4 \\
\hline Encrusting red algae & 2 & 2 & 6 & 4 & 4 & 5 & 6 & 8 & 7 & 1 \\
\hline Orange encrusting sponge & 13 & 10 & 5 & 2 & 3 & 1 & 2 & 2 & 1 & 3 \\
\hline Macrocystis pyrifera $>1 \mathrm{~m}$ & 2 & 1 & 5 & 14 & 2 & 3 & 0 & 2 & 2 & 4 \\
\hline Astrangia lajollaensis & 1 & 4 & 4 & 0 & 4 & 5 & 5 & 2 & 4 & 3 \\
\hline Filamentous red algae & 7 & 0 & 3 & 0 & 0 & 0 & 8 & 0 & 9 & 3 \\
\hline Crisia spp. & 0 & 0 & 5 & 15 & 6 & 0 & 1 & 1 & 0 & 0 \\
\hline Bugula spp. & 2 & 3 & 0 & 8 & 4 & 0 & 8 & 0 & 1 & 0 \\
\hline Aglaophenia spp. & 0 & 2 & 3 & 0 & 0 & 3 & 6 & 2 & 2 & 2 \\
\hline Macrocystis pyrifera $<1 \mathrm{~m}$ & 4 & 8 & 1 & 3 & 1 & 0 & 1 & 1 & 0 & 0 \\
\hline Strongylocentrotus purpuratus & 6 & 2 & 2 & 1 & 0 & 5 & 0 & 1 & 1 & 0 \\
\hline Bossiella spp. & 6 & 0 & 1 & 1 & 2 & 0 & 0 & 0 & 1 & 5 \\
\hline Lagenocella spp. & 0 & 1 & 0 & 4 & 3 & 6 & 1 & 0 & 0 & 0 \\
\hline Laurencia pacifica & 1 & 9 & 0 & 0 & 0 & 4 & 0 & 0 & 0 & 0 \\
\hline Eupentacta quinquesemita & 1 & 2 & 1 & 1 & 1 & 1 & 2 & 0 & 0 & 3 \\
\hline Kallymenia pacifica & 2 & 0 & 0 & 0 & 0 & 1 & 1 & 3 & 2 & 0 \\
\hline Tethya aurantia & 0 & 1 & 1 & 1 & 0 & 1 & 0 & 2 & 0 & 3 \\
\hline Cellaria spp. & 0 & 0 & 1 & 1 & 1 & 1 & 3 & 0 & 1 & 0 \\
\hline Mucus tube polychaete & 0 & 0 & 0 & 0 & 7 & 1 & 0 & 0 & 0 & 0 \\
\hline Archidistoma psammion & 0 & 0 & 0 & 0 & 0 & 1 & 3 & 0 & 3 & 0 \\
\hline Strongylocentrotus franciscanus & 1 & 0 & 3 & 0 & 1 & 0 & 0 & 1 & 1 & 0 \\
\hline Dodecaceria spp. & 1 & 2 & 1 & 1 & 0 & 0 & 1 & 0 & 0 & 0 \\
\hline Filamentous green algae & 1 & 0 & 1 & 3 & 1 & 0 & 0 & 0 & 0 & 0 \\
\hline Plocamium pacificum & 0 & 1 & 0 & 0 & 0 & 0 & 1 & 0 & 1 & 3 \\
\hline
\end{tabular}


Table 29. Daytona 100 point contact "species" ranked by the sum of points for fall 2014 through spring 2019._Continued

$[>$, greater than; m, meter; <, less than]

\begin{tabular}{|c|c|c|c|c|c|c|c|c|c|c|}
\hline Species name & Fall 2014 & $\begin{array}{c}\text { Spring } \\
2015\end{array}$ & Fall 2015 & $\begin{array}{c}\text { Spring } \\
2016\end{array}$ & Fall 2016 & $\begin{array}{c}\text { Spring } \\
2017\end{array}$ & Fall 2017 & $\begin{array}{c}\text { Spring } \\
2018\end{array}$ & Fall 2018 & $\begin{array}{c}\text { Spring } \\
2019\end{array}$ \\
\hline Pterygophora californica & 0 & 0 & 0 & 0 & 2 & 0 & 1 & 1 & 0 & 2 \\
\hline Corynactis californica & 0 & 3 & 0 & 1 & 0 & 0 & 0 & 0 & 0 & 1 \\
\hline Diopatra ornata & 1 & 0 & 0 & 0 & 1 & 0 & 1 & 0 & 2 & 0 \\
\hline Metandrocarpa dura & 0 & 0 & 0 & 4 & 0 & 0 & 0 & 0 & 1 & 0 \\
\hline Nienburgia andersoniana & 0 & 1 & 0 & 2 & 1 & 0 & 1 & 0 & 0 & 0 \\
\hline Acarnus erithacus & 0 & 1 & 0 & 0 & 2 & 0 & 0 & 0 & 1 & 0 \\
\hline Didemnum carnulentum & 1 & 1 & 0 & 2 & 0 & 0 & 0 & 0 & 0 & 0 \\
\hline Hippodiplosia insculpta & 0 & 0 & 0 & 3 & 0 & 1 & 0 & 0 & 0 & 0 \\
\hline Abietinaria spp. & 0 & 0 & 1 & 0 & 0 & 0 & 0 & 1 & 1 & 0 \\
\hline Lissothuria nutriens & 0 & 0 & 0 & 0 & 0 & 0 & 0 & 0 & 2 & 1 \\
\hline Pholad clam & 0 & 0 & 0 & 0 & 1 & 1 & 0 & 0 & 0 & 1 \\
\hline Sargassum muticum & 0 & 0 & 1 & 0 & 0 & 0 & 0 & 1 & 0 & 1 \\
\hline Spheciospongia confoederata & 2 & 1 & 0 & 0 & 0 & 0 & 0 & 0 & 0 & 0 \\
\hline Synoicum spp. & 0 & 0 & 0 & 0 & 0 & 0 & 0 & 0 & 0 & 3 \\
\hline Anthopleura sola & 0 & 0 & 0 & 0 & 0 & 0 & 1 & 0 & 0 & 1 \\
\hline Balanus spp. & 0 & 0 & 0 & 0 & 0 & 0 & 0 & 0 & 1 & 1 \\
\hline Bryopsis corticulans & 0 & 0 & 0 & 0 & 0 & 2 & 0 & 0 & 0 & 0 \\
\hline Colpomenia spp. & 1 & 0 & 0 & 0 & 0 & 0 & 1 & 0 & 0 & 0 \\
\hline Cucumaria salma & 0 & 1 & 0 & 0 & 0 & 0 & 0 & 0 & 0 & 1 \\
\hline Cystodytes lobatus & 0 & 0 & 0 & 1 & 0 & 0 & 0 & 1 & 0 & 0 \\
\hline Acanthacora cyanocrypta & 0 & 0 & 0 & 0 & 0 & 1 & 0 & 0 & 0 & 0 \\
\hline Gigartina exasperata & 1 & 0 & 0 & 0 & 0 & 0 & 0 & 0 & 0 & 0 \\
\hline Codium setchellii/hubbsii & 0 & 1 & 0 & 0 & 0 & 0 & 0 & 0 & 0 & 0 \\
\hline Crassadoma gigantea & 0 & 0 & 0 & 0 & 1 & 0 & 0 & 0 & 0 & 0 \\
\hline Dodecaceria fewkesi & 0 & 0 & 0 & 0 & 0 & 0 & 0 & 0 & 0 & 1 \\
\hline Leucosolenia eleanor & 0 & 0 & 0 & 0 & 0 & 0 & 0 & 0 & 1 & 0 \\
\hline Opuntiella californica & 0 & 0 & 0 & 0 & 0 & 0 & 1 & 0 & 0 & 0 \\
\hline Phidolopora pacifica & 0 & 1 & 0 & 0 & 0 & 0 & 0 & 0 & 0 & 0 \\
\hline Phragmatopoma californica & 0 & 0 & 0 & 0 & 0 & 0 & 0 & 1 & 0 & 0 \\
\hline Plumularia spp. & 0 & 0 & 0 & 0 & 0 & 0 & 0 & 0 & 0 & 1 \\
\hline Polysiphonia spp. & 0 & 0 & 0 & 0 & 0 & 0 & 1 & 0 & 0 & 0 \\
\hline Pterosiphonia spp. & 0 & 0 & 0 & 0 & 1 & 0 & 0 & 0 & 0 & 0 \\
\hline Red algal turf & 0 & 0 & 0 & 0 & 0 & 1 & 0 & 0 & 0 & 0 \\
\hline Spirobranchus spinosus & 0 & 0 & 0 & 0 & 0 & 0 & 1 & 0 & 0 & 0 \\
\hline Stylantheca porphyra & 0 & 0 & 0 & 1 & 0 & 0 & 0 & 0 & 0 & 0 \\
\hline Taonia lennebackerae & 1 & 0 & 0 & 0 & 0 & 0 & 0 & 0 & 0 & 0 \\
\hline Unidentified sponge & 0 & 0 & 0 & 0 & 0 & 0 & 0 & 0 & 0 & 1 \\
\hline
\end{tabular}


Table 30. Daytona 100 fish counts_Adult (Juvenile)—in fall 2014 through spring 2019 by species.

[f, female; m, male]

\begin{tabular}{|c|c|c|c|c|c|c|c|c|c|c|}
\hline Species name & $\begin{array}{l}\text { Fall } \\
2014\end{array}$ & $\begin{array}{c}\text { Spring } \\
2015\end{array}$ & $\begin{array}{l}\text { Fall } \\
2015\end{array}$ & $\begin{array}{c}\text { Spring } \\
2016\end{array}$ & $\begin{array}{l}\text { Fall } \\
2016 \\
\end{array}$ & $\begin{array}{c}\text { Spring } \\
2017\end{array}$ & $\begin{array}{l}\text { Fall } \\
2017 \\
\end{array}$ & $\begin{array}{c}\text { Spring } \\
2018\end{array}$ & $\begin{array}{l}\text { Fall } \\
2018 \\
\end{array}$ & $\begin{array}{c}\text { Spring } \\
2019\end{array}$ \\
\hline Atherinops affinis & 0 & 0 & 0 & 0 & 0 & 300 & 35 & 0 & 0 & 0 \\
\hline Brachyistius frenatus & 3 & 5 & 5 & 0 & 10 & 0 & 4 & 0 & 4 & 0 \\
\hline Caulolatilus princeps & 0 & 0 & 0 & 0 & 5 & 0 & 4 & 0 & 4 & 3 \\
\hline Chromis punctipinnis & 1,611 & $331(105)$ & 322 & 120 & 333 & 440 & 168 & 177 & 136 & 450 \\
\hline Rhinogobiops nicholsii & 43 & 10 & 2 & 2 & 6 & 3 & 2 & 3 & 0 & 1 \\
\hline Embiotoca jacksoni & 9 & 26 & 11 & 7 & 18 & 4 & 7 & 0 & 10 & 13 \\
\hline Embiotoca lateralis & 9 & 18 & 2 & 1 & 4 & 0 & 1 & 2 & 3 & 4 \\
\hline Girella nigricans & 6 & 3 & 1 & 22 & 5 & 0 & 4 & 2 & 0 & 0 \\
\hline Halichoeres semicinctus & 0 & 0 & 0 & 0 & 6 & 0 & 1 & 0 & 0 & 1 \\
\hline Heterostichus rostratus & 0 & 0 & 0 & 0 & 0 & 0 & 0 & 0 & 1 & 0 \\
\hline Hypsurus caryi & 0 & 0 & 0 & 0 & 2 & 0 & 0 & 0 & 0 & 0 \\
\hline Hypsypops rubicundus & $9(2)$ & $13(1)$ & $7(1)$ & 4 & 15 & 2 & 11 & 6 & 1 & 7 \\
\hline Medialuna californiensis & 2 & 6 & 10 & 0 & 7 & 12 & 4 & 1 & 5 & 8 \\
\hline Oxyjulis californica & 1,448 & 216 & 225 & 92 & 164 & 707 & 240 & 643 & 354 & 689 \\
\hline Oxylebius pictus & 35 & 21 & 7 & 2 & 5 & 4 & 2 & 1 & 2 & 5 \\
\hline Paralabrax clathratus & 91 & 47 & 21 & 18 & 62 & 26 & 59 & 27 & 37 & 44 \\
\hline Rhacochilus vacca & 4 & 7 & 1 & 0 & 0 & 1 & 3 & 1 & 11 & 2 \\
\hline Scorpaena guttata & 0 & 1 & 0 & 0 & 0 & 0 & 0 & 0 & 0 & 0 \\
\hline Scorpaenichthys marmoratus & 0 & 2 & 0 & 0 & 0 & 0 & 0 & 0 & 0 & 0 \\
\hline Sebastes atrovirens & 36 & 59 & 7 & 4 & 13 & 2 & 10 & 7 & 3 & 1 \\
\hline Sebastes caurinus & 1 & 0 & 0 & 0 & 0 & 0 & 0 & 0 & 0 & 0 \\
\hline Sebastes chrysomelas & 9 & 1 & 0 & 1 & 0 & 1 & 3 & 0 & 0 & 0 \\
\hline Sebastes mystinus & 203 & 22 & 59 & 14 & 17 & 8 & 8 & 9 & 2 & 19 \\
\hline Sebastes serranoides & 25 & 33 & 24 & 5 & 18 & 4 & 13 & 11 & 2 & 0 \\
\hline Sebastes serriceps & 2 & 0 & 0 & 0 & 0 & 0 & 1 & 0 & 0 & 0 \\
\hline Semicossyphus pulcher (f) & $15(2)$ & $35(3)$ & $22(2)$ & $25(1)$ & 62 & 32 & 32 & 35 & 21 & 39 \\
\hline Semicossyphus pulcher (m) & 27 & 25 & 9 & 18 & 7 & 10 & 6 & 11 & 6 & 12 \\
\hline Stereolepis gigas & 0 & 0 & 0 & 0 & 0 & 0 & 1 & 0 & 0 & 0 \\
\hline
\end{tabular}

\section{Long-term Patterns}

Though purple urchin densities crept up at all the supersites in the last 2 years, only Daytona 100 has shown any signs of active grazing. This supersite, which encompasses a patchwork of urchin and kelp dominated areas, exceeded a mean density of 1,000 purple urchins per swath in the last spring trip (2019). The next highest $S$. purpuratus density was at Dutch Harbor, where the mean density wavered a bit under 400 per swath - a record level at the supersite. The densities at West End, although well below those measured there in the 1980s and 1990s, were the highest since 2001. Red urchin densities have increased slightly at West End, flattened at Nav Fac 100 and Dutch Harbor, and declined gradually at Daytona 100. Figure 39 shows mean $S$. purpuratus and $S$. franciscanus densities since the original monitoring project was established in 1980 (appendix 1). In this figure, and the following figures showing long-term data, Daytona 100 and Nav Fac 100 are represented only by their long-established subsites (original five $20-\mathrm{m}^{2}$ swaths), and data from the additional $50-\mathrm{m}$ transects that were added in 2014 are not included. 
Sea urchin counts (mean / $20 \mathrm{~m}^{2}$ )

(1) Legacy stations used for long-term trend
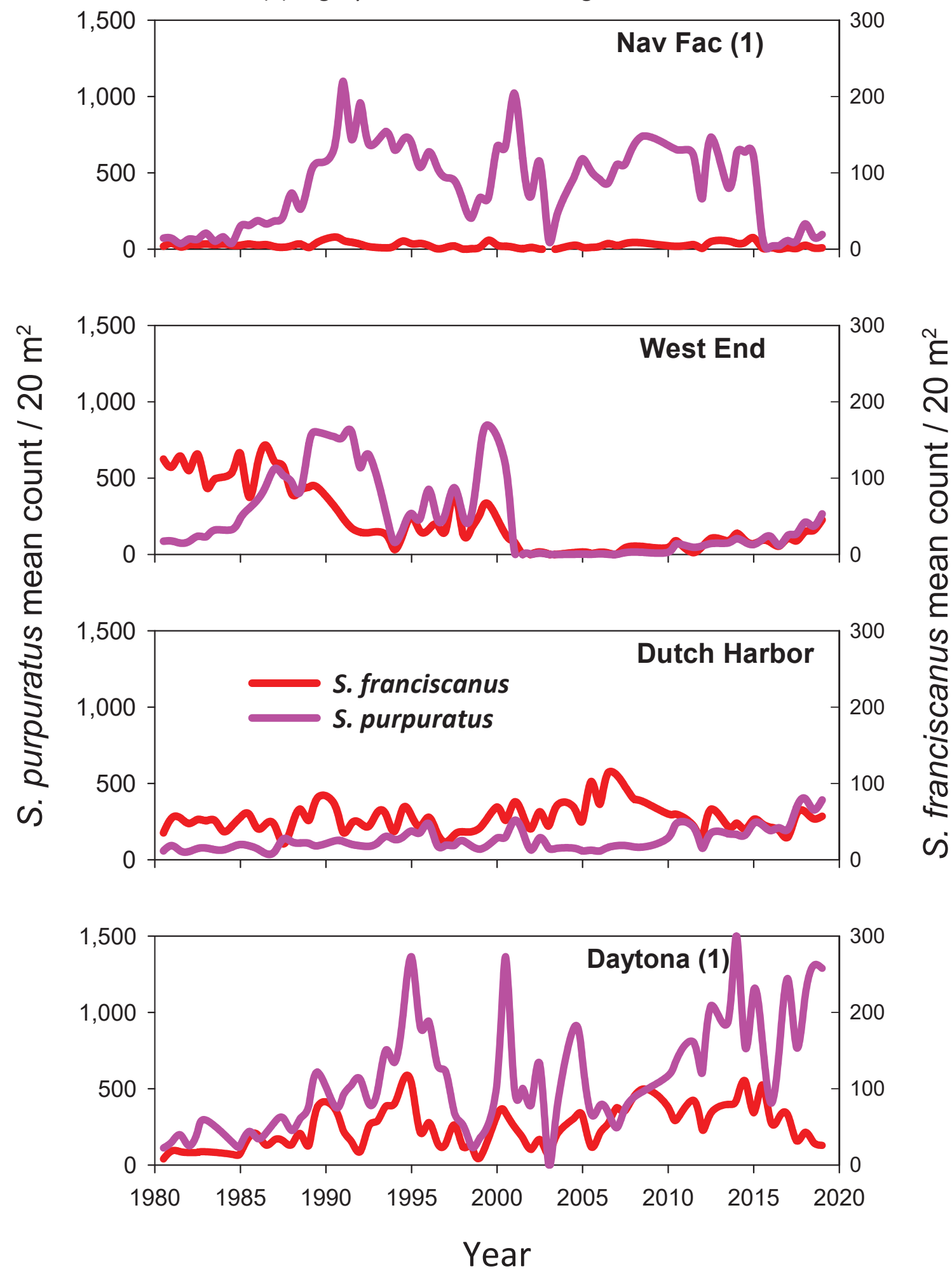

Figure 39. Long-term trends in urchin abundance. [Note that Nav Fac and Daytona are the legacy sites (half the size of the supersites) presented to show history. Strongylocentrotus purpuratus and S. franciscanus are shown on different scales] 
Nav Fac first became heavily grazed by sea urchins in 1991. The corresponding rapid loss of kelps can be seen in figure 40. Several abrupt, but brief, declines in purple urchin density are apparent in figure 39. Between 2003 and 2015, the site consisted of distinct patches of algal dominated and urchin dominated areas. Finally, there was a precipitous loss of purple urchins there in 2015, which was followed by a pulse of fleshy red algae, a moderate Macrocystis recruitment, and recovery of understory kelps. In the most recent sampling periods, much of the site was dominated by the fucoid C. osmundacea and annual brown algae - including various dictyotales and the invasive alga $S$. horneri.

Daytona 100 followed a similar trajectory in that it first became urchin dominated in 1995, and dynamic swings in urchin abundance since then (fig. 39) were met with varying response from fleshy red algae, understory kelps, and Macrocystis (fig. 41). These algae, and C. osmundacea, persisted but had a very patchy distribution when urchin numbers rebounded. Daytona continued to be a patchwork of kelp and urchin dominated areas in 2019.

At Dutch Harbor, recruitment pulses of M. pyrifera followed by attrition, senescence, and new recruitment occurred in cyclic patterns of 2- to 3-year duration for two and a half decades. These recruitments appear as repeating peaks in figure 42. After 2007, however, there was an interruption to this pattern. In 2016, the first large recruitment in several years was observed in the fall following the El Niño storms of the previous winter. This cohort has since undergone attrition and, in spring 2019, few adult M. pyrifera remained. There was, however, a fairly large recruitment of juvenile Macrocystis that could result in renewed numbers of mature plants in the fall.

Following the loss of urchins at West End in 2001 (fig. 39), M. pyrifera and understory kelps recruited heavily, and at this site, giant kelp also demonstrated a pattern of recruitment and attrition similar to- though more extreme than - that seen at Dutch Harbor. The magnitude of successive recruitments at West End, however, waned as understory kelp numbers and fleshy red algal benthic cover increased (fig. 43). This site is the most exposed to swell and perhaps, because these lower growing forms are better able to survive winter storms, they may have been able to outcompete $M$. pyrifera there. Since 2010, West End M. pyrifera densities have remained low but understory kelp and red algae took on their own oscillating patterns. In 2016, M. pyrifera underwent a modest recruitment similar to Dutch Harbor. Although considerably smaller than previous recruitment pulses at this site, it was the largest in several years and corresponded with a decline in red algal cover. In the most recent year, it appears that the decline in red algal cover may have been exploited by understory kelps rather than M. pyrifera.

In addition to the urchin and macroalgal dynamics, we have tracked for nearly four decades, long-term changes in the densities of the herbivorous gastropod, M. undosa show interesting trends. Densities of M. undosa have almost always been substantially higher at Nav Fac than at other sites. Though there were several unsynchronized peaks and falls in abundance among the sites prior to 2002, all sites had minimal numbers of this snail between 2002 and 2015. The decline and subsequent low levels of this species suggest a catastrophic event occurred in 2001-02 (fig. 44). Supporting this conclusion, one of us (Michael Kenner) recalls observing north facing beaches on SNI littered with $M$. undosa shells in the early 2000s. Recovery began at Nav Fac in fall 2015 and somewhat later at the other sites. One possible cause for the recent increase in $M$. undosa densities is that the species is reacting to release from predation by sea stars that have recently been reduced by SSWS.

As mentioned earlier, SSWS has devastated multiple species of sea stars along hundreds of miles of the Pacific coast of North America. Three asteroid species that were affected by the disease show very different histories of abundance over time at SNI. Pisaster giganteus, an important predator on snails, barnacles and bivalves, shows a complex pattern of abundance with a few brief synchronous declines among the sites until 2014 when densities at all sites dropped simultaneously (fig. 45). Pycnopodia helianthoides, a voracious predator on an assortment of invertebrate taxa, and the only sea star thought to have some potential for control of sea urchin populations in this system, was not observed at our sites at SNI until the early 1990s. It is not possible to say whether it is a periodic member of the SNI nearshore community because of infrequent recruitment success or whether it was eliminated by a prior disease outbreak before sampling began in 1980. After appearing in 1991, it was frequently seen at low densities at all sites, but most predictably at Dutch Harbor (fig. 46). In 2014, it disappeared from all sites and none have been observed since. Finally, P. miniata, which is a scavenger, experienced a major decline at all sites in the early 1980s apparently as a result of a disease event (fig. 47). This decline was not well synchronized among sites, however, lagging by 2 years or more between reductions observed at Nav Fac and other sites. Beginning in the early 1990s, it returned in moderate densities before eventually reaching higher numbers in the mid-2000s. It declined at all sites about 6 months later than the other two sea stars mentioned earlier and has since returned to moderate densities similar to those seen in the 1990s. 


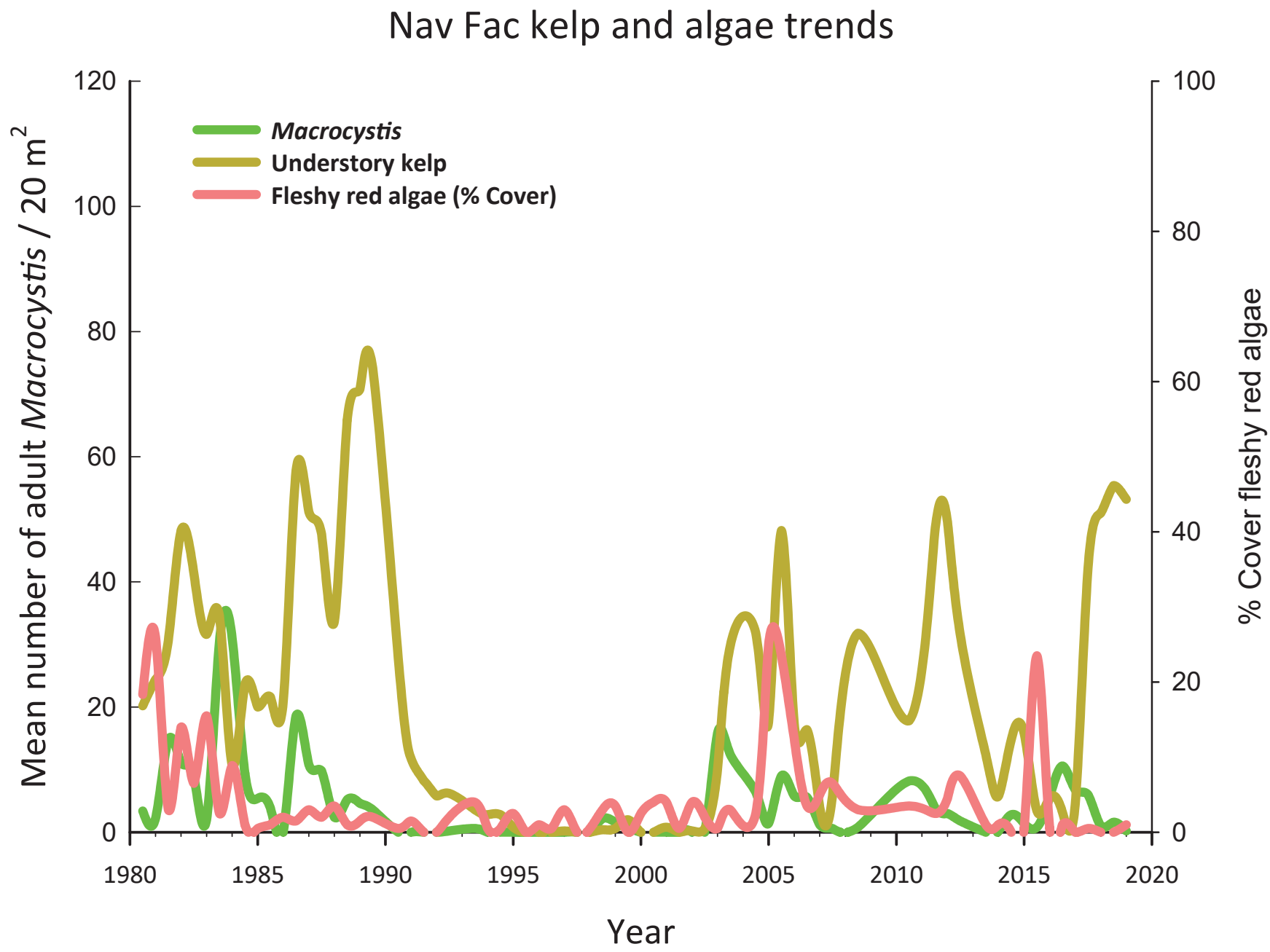

Figure 40. Kelp (Macrocystis pyrifera greater than 1 meter [m] tall and understory species) and fleshy red algae cover trends over time at Nav Fac. [Original transects only used for long-term trends] 


\section{Daytona kelp and algae trends}

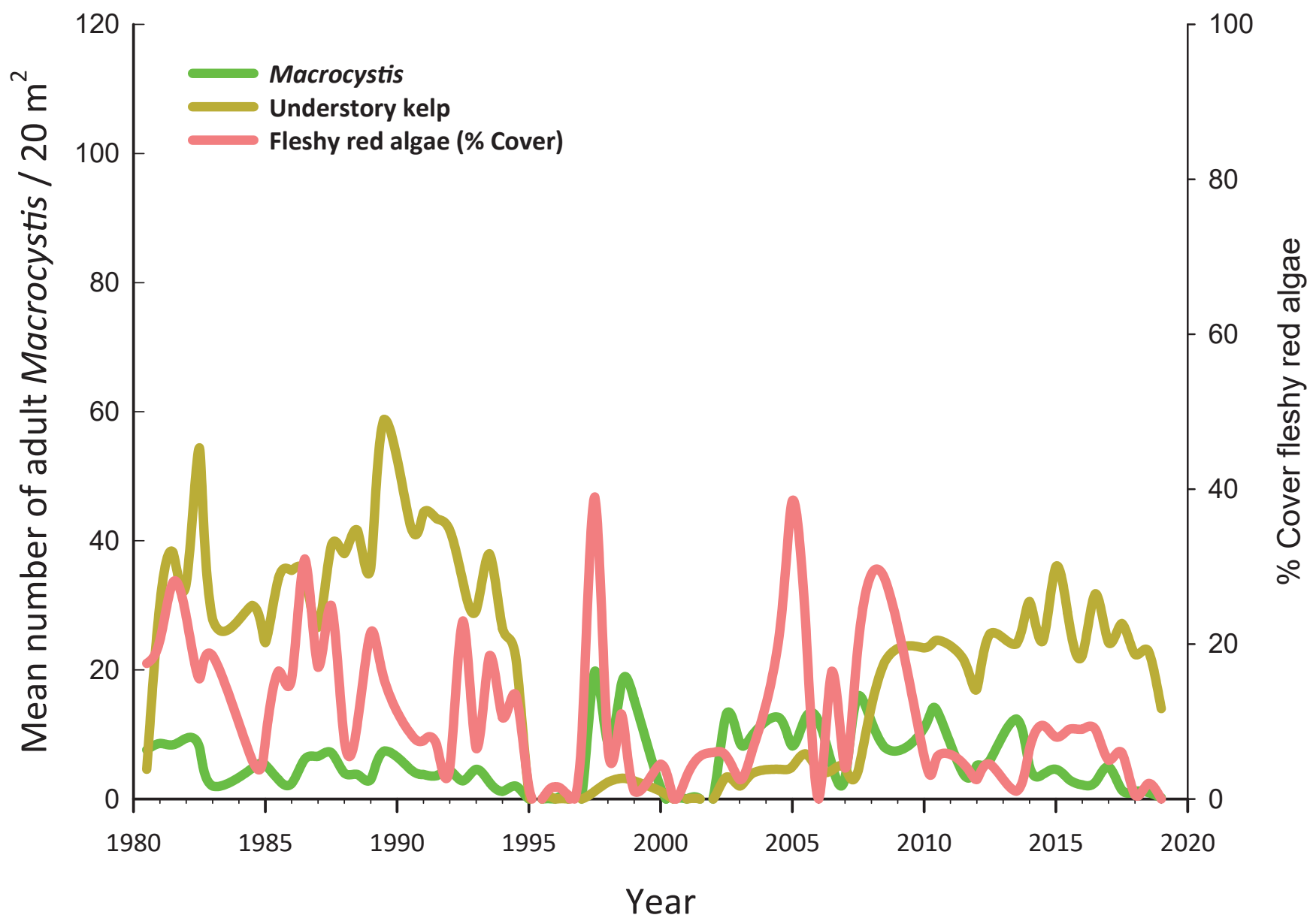

Figure 41. Kelp (Macrocystis pyrifera greater than 1 meter [m] tall and understory species) and fleshy red algae cover trends over time at Daytona. [Original transects only used for long-term trends] 
Dutch Harbor kelp and red algae trends

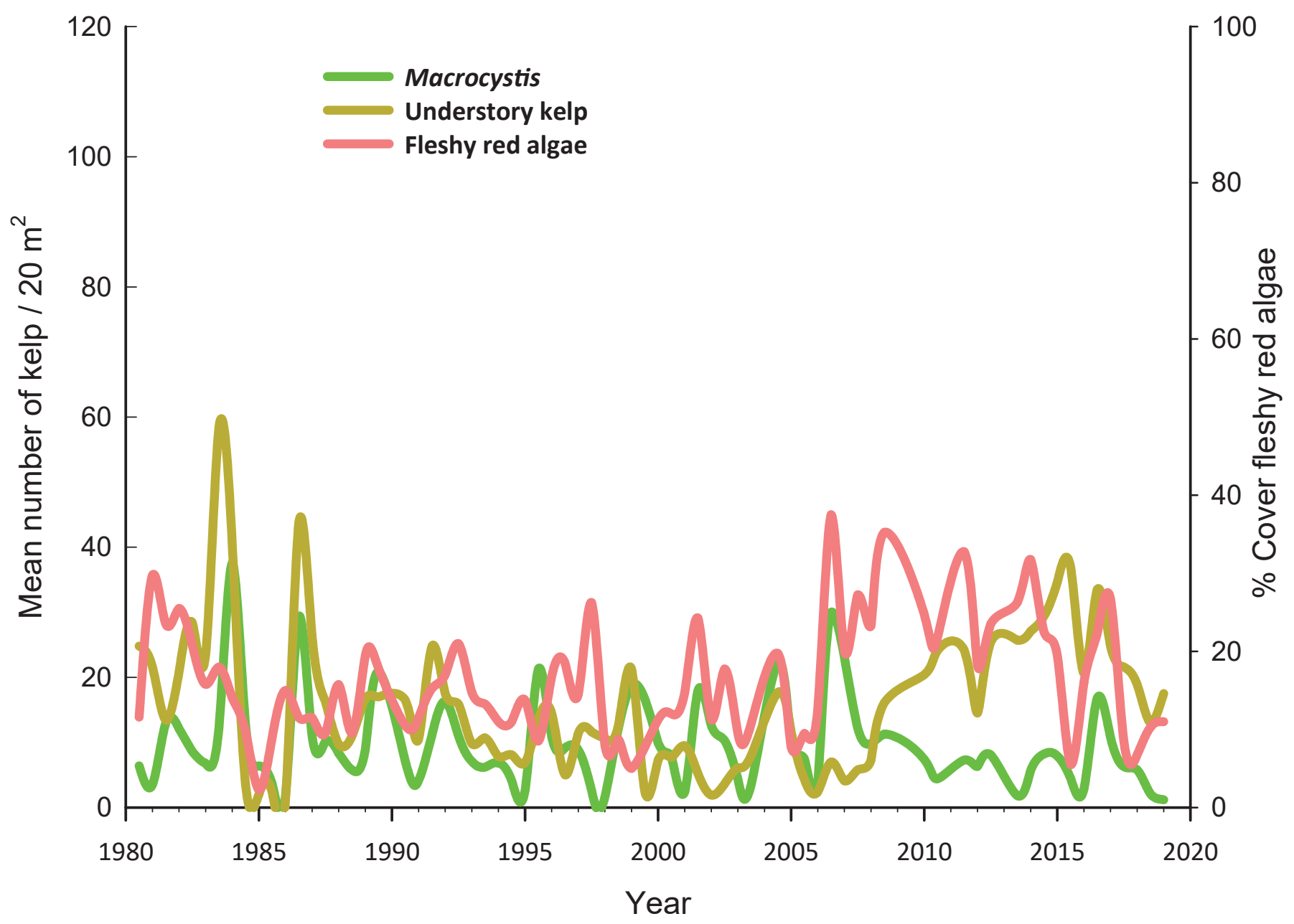

Figure 42. Kelp (Macrocystis pyrifera greater than 1 meter [m] tall and understory species) and fleshy red algae cover trends over time at Dutch Harbor. 


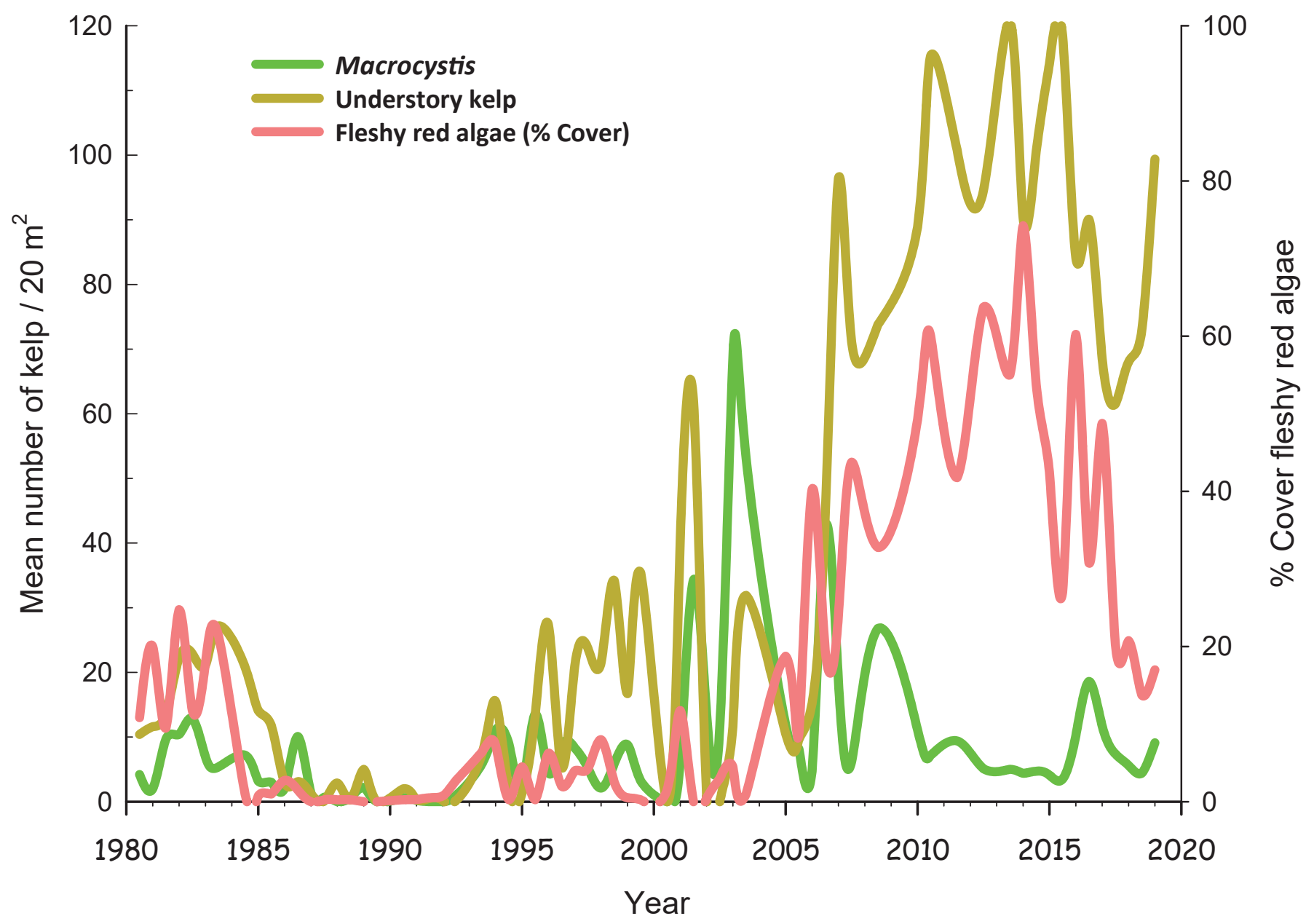

Figure 43. Kelp (Macrocystis pyrifera greater than 1 meter [m] tall and understory species) and fleshy red algae cover trends over time at West End. 


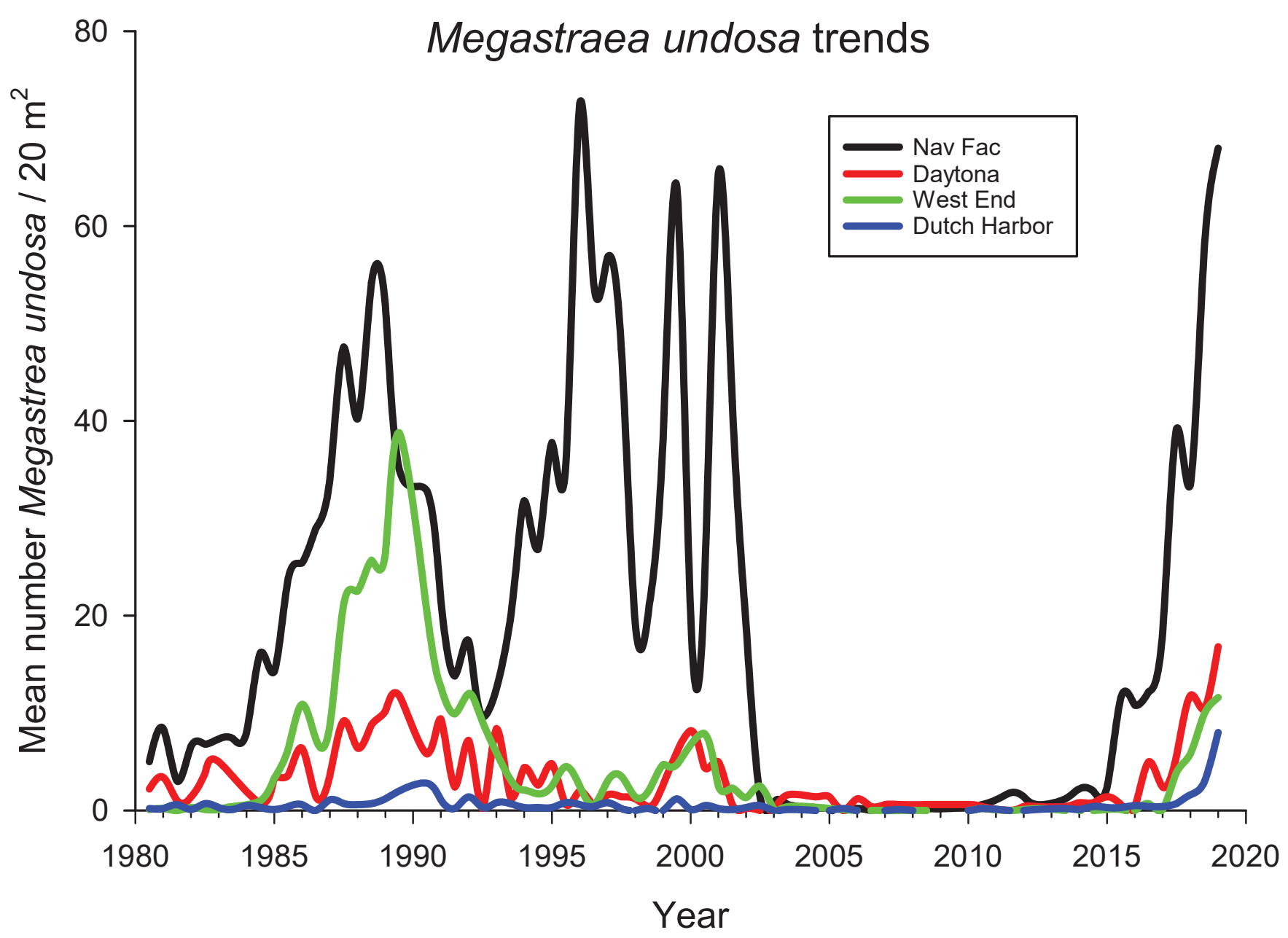

Figure 44. Megastraea undosa trends over time at West End, Dutch Harbor, and original five swaths of Nav Fac and Daytona from fall 1980 to spring 2019. 


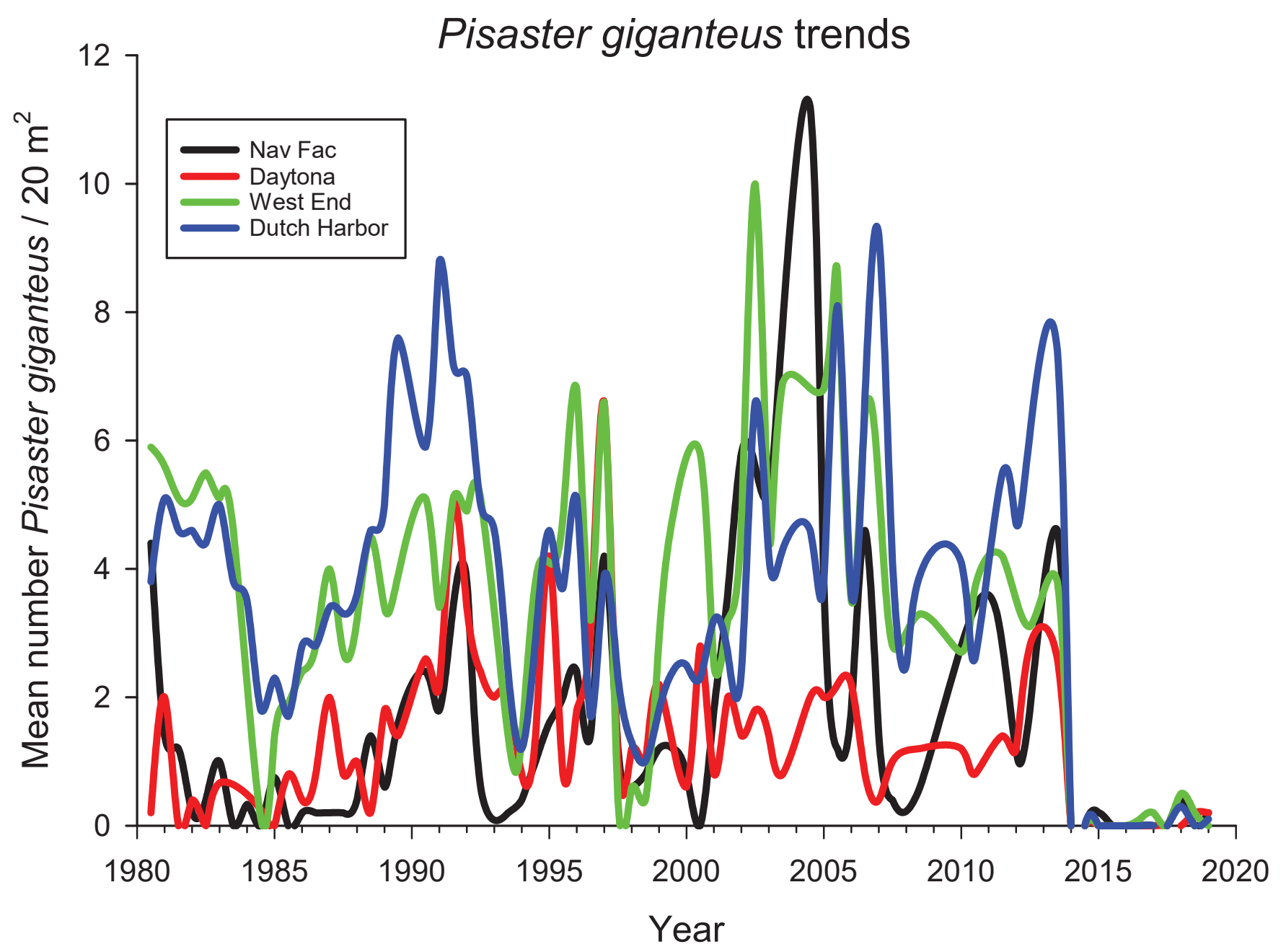

Figure 45. Pisaster giganteus trends over time at West End, Dutch Harbor, and original five swaths of Nav Fac and Daytona from fall 1980 to spring 2019. 


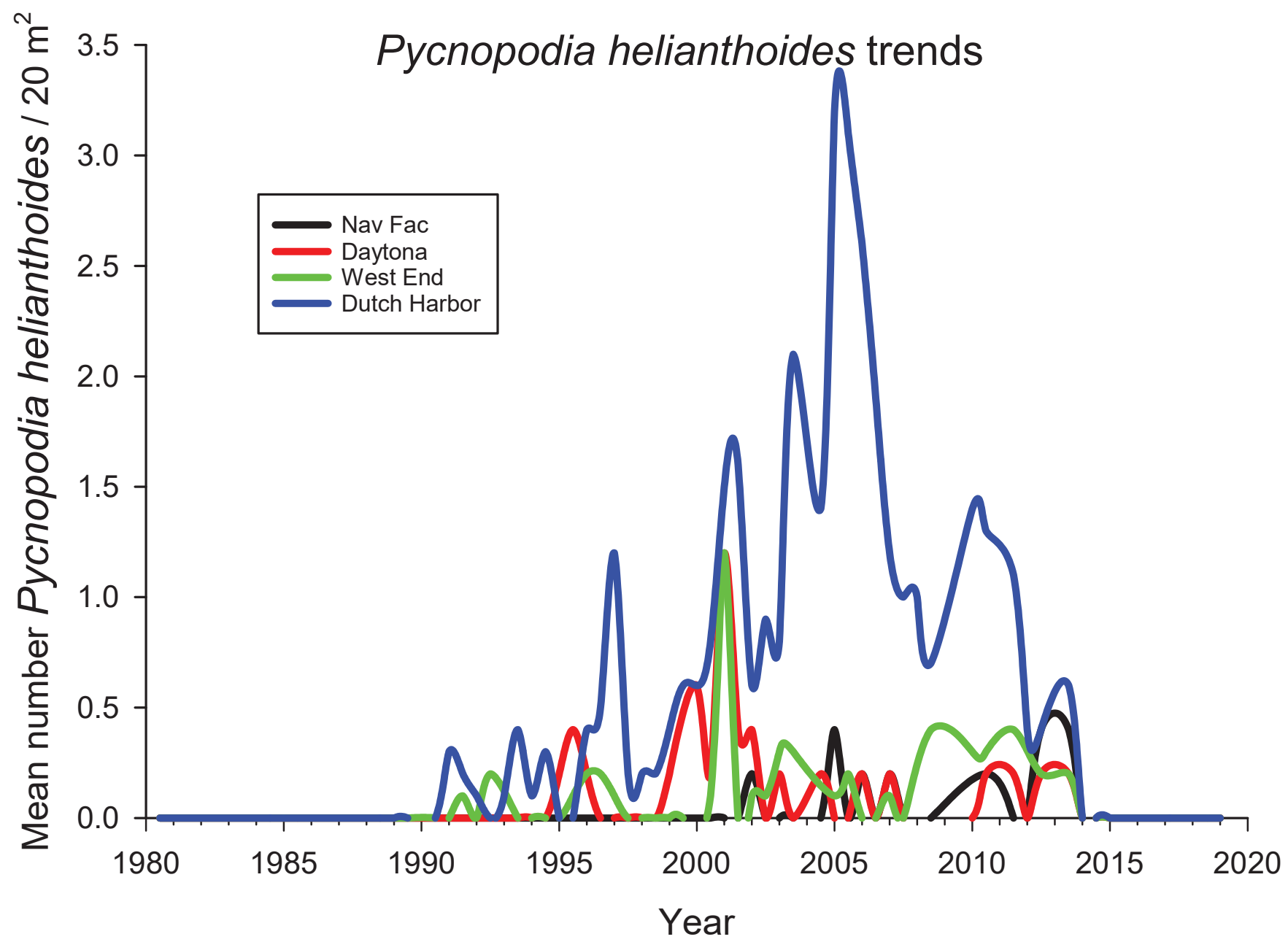

Figure 46. Pycnopodia helianthoides trends over time at West End, Dutch Harbor, and original five swaths of Nav Fac and Daytona from fall 1980 to spring 2019. 


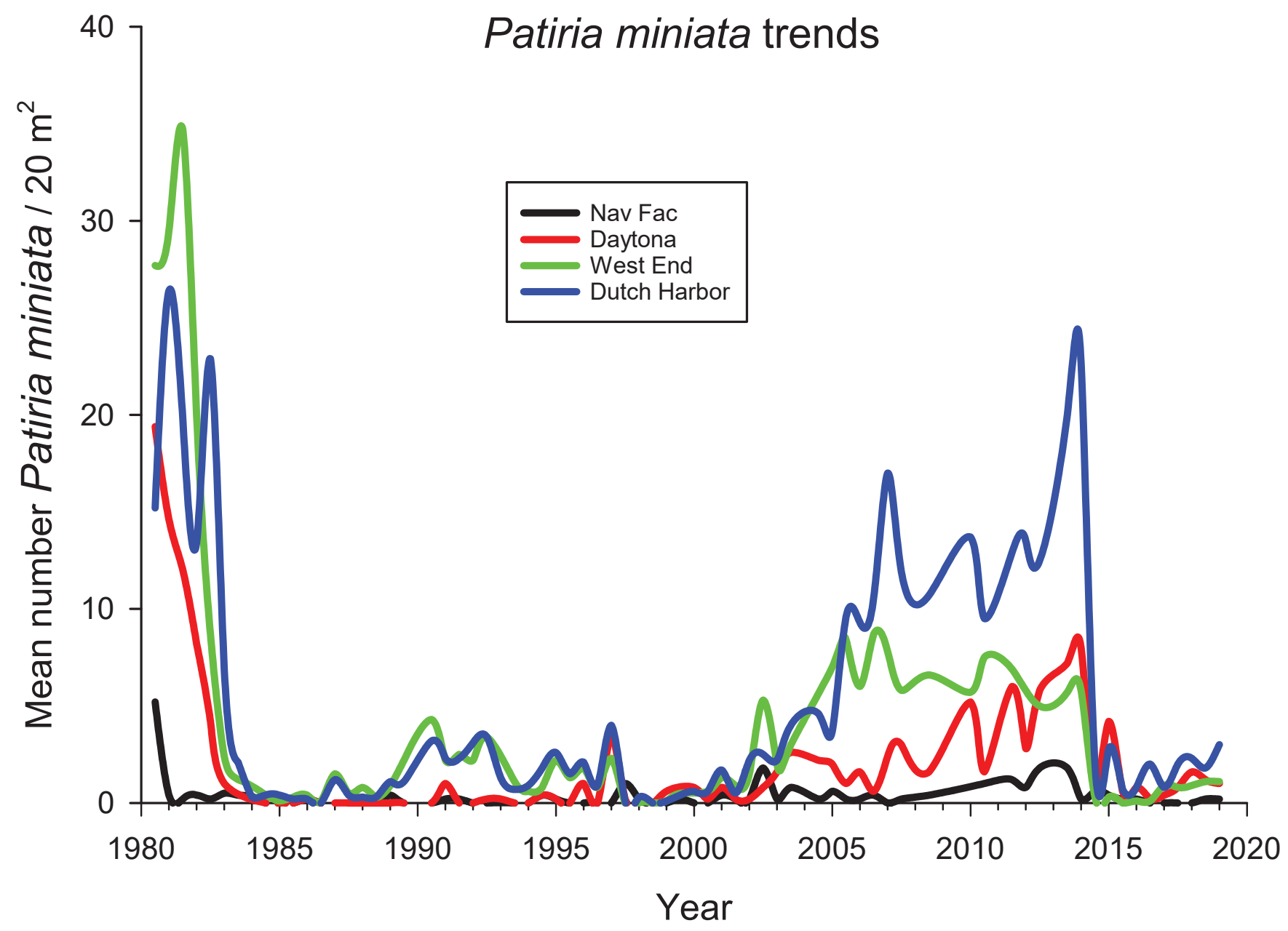

Figure 47. Patiria miniata trends over time at West End, Dutch Harbor, and original five swaths of Nav Fac and Daytona from fall 1980 to spring 2019. 


\section{Conclusions and Management Considerations}

After nearly four decades of monitoring subtidal sites around San Nicolas Island (SNI), the U.S. Geological Survey (USGS) has amassed a wealth of data about how the nearshore community there responds to change. During this time, several El Niño events have arrived with sometimes violent storms and unusually warm water. Invertebrate diseases have decimated abalone, sea star, and sea urchin populations at different times and scales around the island, which sometimes resulted in dramatic localized community shifts. Fisheries for red sea urchins, spiny lobster, and some finfishes have exploited the area with unknown consequences. An invasive brown alga (S. horneri), with the potential to at least seasonally dominate the algal community, became established at one of the sites. These perturbations occurred while sea otters, an important species that had been extirpated from the ecosystem a century before, expanded from a fledgling re-introduced group to a population of more than 120 animals.

These types of perturbations are expected to continue to influence the nearshore ecosystem around SNI. Sargassum horneri will likely spread around the island, new disease outbreaks are likely to change the balance of species, and sea otters may eventually reach carrying capacity in the system and will have dramatic direct and indirect effects on community structure and composition. In addition, there could be new physical and biological challenges to the system. Warming seas, ocean acidification, rising sea level, and more violent storms have been predicted. New diseases and invasive species seem inevitable.

Each site we monitor has its own character that results from such physical factors as wave exposure, bottom relief and substrate hardness, as well as site-specific stochastic ecological history. It is only through long-term studies such as this that we can gather an appreciation for what is an expected response to disturbance and what changes can be cause for concern. Thus, continued monitoring of this system represents a unique opportunity to build a real understanding of the factors that drive ecosystem dynamics around SNI, to understand the role of top predators in ecosystem functionality, and to elucidate the ecosystem components that create resiliency to new and emerging threats.

Our results demonstrate the value of long-term ecosystem monitoring. Continuing the current monitoring program can be used to apprise managers of the changing ecosystem and provide information to assist in decision making. The data also point to the potential value of an island-wide survey to help disentangle how forces such as predation, disease, and storms interact with stabilizers such as habitat and community complexity. An island-wide survey also could provide an opportunity to map the extent of the invasive alga $S$. horneri and remnant populations of abalone. Such an investigation could give resource managers further insight into the workings of the ecosystem surrounding SNI.

\section{References Cited}

Abbott, I., and Hollenberg, G., 1976, Marine algae of California: Stanford, California, Stanford University Press, 844 p.

Cowen, R.K., 1985, Large scale pattern of recruitment by the labrid, Semicossyphus pulcher-Causes and implications: Journal of Marine Research, v. 43, no. 3, p. 719-742, https://doi.org/10.1357/002224085788440376.

Cumberland, H.L., 1995, A life history analysis of the Kellet's whelk, Kelletia kelletii: San Diego, California, USA, San Diego State University.

Dayton, P.K., Tegner, M.J., Edwards, P.B., and Riser, K.L., 1998, Sliding baselines, ghosts, and reduced expectations in kelp forest communities: Ecological Applications, v. 8, no. 2, p. 309-322, https://doi.org/10.1890/10510761(1998)008[0309:SBGARE]2.0.CO;2.

Duggins, D.O., Simenstad, C.A., and Estes, J.A., 1989, Magnification of secondary production by kelp detritus in coastal marine ecosystems: Science, v. 245 , no. 4914, p. 170-173, https://doi.org/10.1126/science.245.4914.170.

Ebert, T.A., 1968, Growth rates of the sea urchin Strongylocentrotus Purpuratus related to food availability and spine abrasion: Ecology, v. 49, no. 6, p. 1075-1091, https://doi.org/10.2307/1934491.

Ebert, T.A., 1977, An experimental analysis of sea urchin dynamics and community interactions on a rock jetty: Journal of Experimental Marine Biology and Ecology, v. 27, no. 1, p. 1-22, https://doi.org/10.1016/0022-0981(77)90050-8.

Ebert, T.A., and Russell, M.P., 1992, Growth and mortality estimates for red sea urchin Strongylocentrotus franciscanus from San Nicolas Island, California: Marine Ecology Progress Series, v. 81, p. 31-41, https://doi.org/10.3354/meps081031.

Harrold, C., and Reed, D.C., 1985, Food availability, sea urchin grazing, and kelp forest community structure: Ecology, v. 66, no. 4, p. 1160-1169, https://doi.org/10.2307/1939168.

Hatfield, B.B., Yee, J.L., Kenner, M.C., and Tomoleoni, J.A., 2019, California sea otter (Enhydra lutris nereis) census results, spring 2019: U.S. Geological Survey Data Series 1118, 12 p., https://doi.org/10.3133/ds1118.

Kenner, M.C., 1992, Population dynamics of the sea urchin Strongylocentrotus purpuratus in a Central California kelp forest—Recruitment, mortality, growth, and diet: Marine Biology, v. 112, no. 1, p. 107-118, https://doi.org/10.1007/BF00349734. 
Kenner, M.C., 2016, Kelp forest monitoring at Naval Base Ventura County, San Nicolas Island, CA-Fall 2015 and Spring 2016 - Second Annual Report: Report to the U.S. Navy, University of California Santa Cruz.

Kenner, M.C., and Tinker, M.T., 2018, Stability and change in kelp forest habitats at San Nicolas Island: Western North American Naturalist, v. 78, no. 4, p. 633-643, https://doi.org/10.3398/064.078.0407.

Lafferty, K.D., 2004, Fishing for lobsters indirectly increases epidemics in sea urchins: Ecological Applications, v. 14, no. 5, p. 1566-1573, https://doi.org/10.1890/03-5088.

Marks, L.M., Salinas-Ruiz, P., Reed, D.C., Holbrook, S.J., Culver, C.S., Engle, J.M., Kushner, D.J., Caselle, J.E., Freiwald, J., Williams, J.P., Smith, J., Aguilar-Rosas, L., and Kaplanis, N., 2015, Range expansion of a non-native, invasive macroalga Sargassum horneri (Turner) C. Agardh, 1820 in the eastern Pacific: BioInvasions Records, v. 4, no. 4, p. 243-248, https://doi.org/10.3391/bir.2015.4.4.02.

Martone, R., and Micheli, F., 2012, Geographic variation in demography of a temperate reef snail-Importance of multiple life-history traits: Marine Ecology Progress Series, v. 457, p. 85-99, https://doi.org/10.3354/meps09693.

Miller, K.A., Engle, J.M., Uwai, S., and Kawai, H., 2007, First report of the Asian seaweed Sargassum filicinum Harvey (Fucales) in California, USA: Biological Invasions, v. 9, no. 5, p. 609-613, https://doi.org/10.1007/s10530-006-9060-2.

Russell, M.P., 1987, Life history traits and resource allocation in the purple sea urchin Strongylocentrotus purpuratus (Stimpson): Journal of Experimental Marine Biology and Ecology, v. 108, no. 3, p. 199-216, https://doi.org/10.1016/0022-0981(87)90085-2.
Schiel, D.R., and Foster, M.S., 2015, The biology and ecology of giant kelp forests: Oakland, California, USA, University of California Press, https://doi.org/10.1525/california/ 9780520278868.001 .0001 .

Stephens, J.S., Larson, R.J., and Pondella, D.J., 2006, Rocky reefs and kelp beds, chap. 9 of Allen, L.G., Pondella, D.J., and Horn, M.H., eds., The ecology of marine fishes - California and adjacent waters: Berkeley and Los Angeles, CA, University of California Press, https://doi.org/10.1525/california/ 9780520246539.003.0009.

Tegner, M.J., and Dayton, P.K., 1991, Sea urchins, El Ninos, and the long term stability of Southern California kelp forest communities: Marine Ecology Progress Series, v. 77, no. 1, p. 49-63, https://doi.org/10.3354/meps077049.

U.S. Fish and Wildlife Service, 2012, Final supplemental environmental impact statement on the translocation of southern Sea Otters: Ventura, California, Ventura Fish and Wildlife Office.

U.S. Navy, 2015, Integrated natural resources management plan for Naval Base Ventura County, San Nicolas Island, California: December 2010, updated December 2015.

VanBlaricom, G.R., Ruediger, J.L., Friedman, C.S., Woodard, D.D., and Hedrick, R.P., 1993, Discovery of withering syndrome among black abalone Haliotis cracherodii Leach, 1814, populations at San Nicolas Island, California: Journal of Shellfish Research, v. 12, p. 185-188.

Wilmers, C.C., Estes, J.A., Edwards, M., Laidre, K.L., and Konar, B., 2012, Do trophic cascades affect the storage and flux of atmospheric carbon? An analysis of sea otters and kelp forests: Frontiers in Ecology and the Environment, v. 10, no. 8, p. 409-415, https://doi.org/10.1890/110176. 


\section{Appendix 1. Sampling History}

In 1980, in anticipation of the translocation of sea otters to San Nicolas Island (SNI), U.S. Fish and Wildlife Service biologists, in cooperation with the University of California Santa Cruz, established the SNI Subtidal Baseline project, a kelp forest monitoring program with the intention of documenting resulting ecosystem changes at the island (Kenner and others, 2013). Six permanent sites were initially installed: Nav Fac, West End Urchin, West End Kelp, West Dutch Harbor, East Dutch Harbor and Daytona Beach. A seventh site, Sandy Cove, was added in 1986. At these sites, kelps and a suite of motile macroinvertebrates were counted on fixed transects, the amount of exposed substrate and the cover of algae and sessile invertebrates were measured at fixed locations, and midwater and benthic fish were counted on transects. Responsibility for monitoring the sites was passed on to the U.S. Geological Survey (USGS) in 1996. The sites have been monitored twice annually in spring and fall with a few exceptions since their inception.

In 2014, the U.S. Navy contracted with USGS to monitor the biota of four rocky reef sites around SNI (fig. 1). The purpose of this project was to continue to expand the 33-year dataset of subtidal monitoring at SNI but with modifications to the protocols so that these data were comparable with those from the other California Channel Islands. To achieve this, the six original USGS sites were expanded or combined as described later, and a few changes were made to data collection, including the addition of some invertebrates to the transect counts and the collection of size data on fish and some invertebrates. This project allows installation managers to characterize the long-term status and trends of communities and populations that occur within SNI's rocky reef and kelp forest habitat and their importance in the ecology of the Channel Islands. This perspective also will help them to understand the potential effects of future perturbations such as disease events or changing environmental conditions.
The original sites consisted of a 50-meter $(\mathrm{m})$ main transect with five $10-\mathrm{m}$ by $2-\mathrm{m}$ benthic band transects (swaths), ten 1-square meter $\left(\mathrm{m}^{2}\right)$ random point contact (RPC) quadrats and five 50-m fish transects. For better comparability to kelp forest monitoring conducted at other Channel Islands, four of the sites were expanded to twice their original size. With the goal to retain compatibility with more than three decades of previously collected data, the four new "supersites" were expanded to consist of a main transect with two 50-m subsections, each with the associated five swaths and ten RPC quadrats. The West End supersite was created by combining West End Urchin and West End Kelp sites which were already physically connected. The Dutch Harbor supersite was created by combining the East Dutch Harbor and West Dutch Harbor sites, which were about $140 \mathrm{~m}$ apart and roughly paralleled each other on two lobes of a reef separated by a sand channel. Nav Fac 100 and Daytona 100 were created by adding new segments to the existing Nav Fac and Daytona sites. Except in the case of Dutch Harbor, where these segments are on adjacent reefs, the 50-m main transects are connected in a linear fashion with the $50-\mathrm{m}$ end of one connecting to the $0-\mathrm{m}$ end of the other.

The expansion of sites for this project did not include additional fish transects. Therefore, because the supersites at West End and Dutch Harbor were formed by combining existing sites, they each have 10 fish transects, whereas Nav Fac 100 and Daytona 100 each have only 5 fish transects.

\section{References Cited}

Kenner, M.C., Estes, J.A., Tinker, M.T., Bodkin, J.L., Cowen, R.K., Harrold, C., Hatfield, B.B., Novak, M., Rassweiler, A., and Reed, D.C., 2013, A multi-decade time series of kelp forest community structure at San Nicolas Island, California (USA): Ecology, v. 94, no. 11, p. 2654. https://doi.org/10.1890/13-0561R.1. 

For more information concerning the research in this report, contact the Director, Western Ecological Research Center

U.S. Geological Survey

3020 State University Drive East

Sacramento, California 95819

https://www.usgs.gov/centers/werc

Publishing support provided by the U.S. Geological Survey Science Publishing Network, Sacramento Publishing Service Center 


\section{$\frac{\mathbb{2}}{3}$}

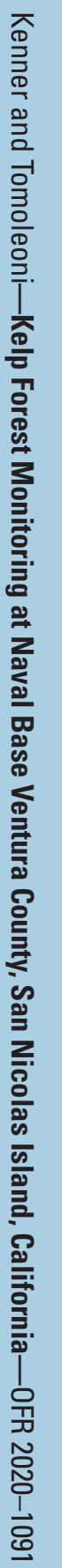

